\title{
CHURCH, SPIRITUALITY, NATION: THE UKRAINIAN GREEK-CATHOLIC CHURCH IN THE SOCIAL LIFE OF UKRAINE
}

Collective monograph

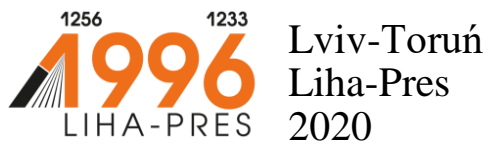




\section{Reviewers:}

Prof. nadzw., dr hab. Stanistaw Kunikowski, Rektor of Cuiavian University in Wloclawek (Republic of Poland);

Prof. $d r$ hab. Joanna Marszałek-Kawa, Uniwersytet Mikołaja Kopernika $w$ Toruniu / Nicolaus Copernicus University (Republic of Poland).

Church, spirituality, nation: the Ukrainian Greek Catholic Church in the social life of Ukraine : collective monograph / M. M. Vehesh, M. M. Palinchak, V. V. Marchuk, N. M Kontsur-Karabinovych etc. Lviv-Toruń : Liha-Pres, 2020. - 224 p.

ISBN 978-966-397-213-8

The monograph of historians of the Vasyl Stefanyk Precarpathian National University, Uzhgorod National University and Ivano-Frankivsk National Technical University of Oil and Gas highlights the ethno-cultural role of the Ukrainian Greek Catholic Church in the social life of Ukraine in the XX century. The church-religious transformations in the western region are analyzed on the base of the little-known source material. Particular attention is paid to the life of church structures after the restoration of independent Ukraine.

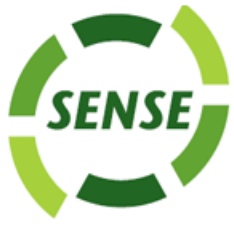

Liha-Pres is an international publishing house which belongs to the category "C" according to the classification of Research School for Socio-Economic and Natural Sciences of the Environment (SENSE) [isn: 3943, 1705, 1704, 1703, 1702, 1701; prefixMetCode: 978966397]. Official website www.sense.nl. 


\section{CONTENTS}

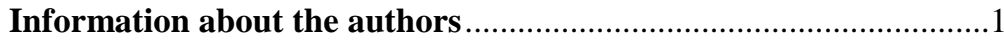

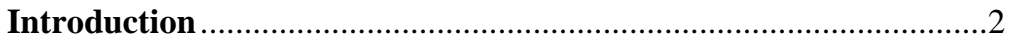

Part 1. The UGCC in the light of historiographical work and

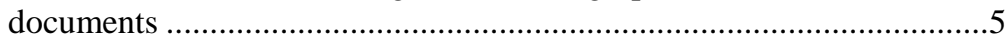

Part 2. The struggle for the national idea preservation as an element of the Greek-Catholic Church activity

Part 3. Contribution to the consolidation

of the State-unifying forces (first decades of the XX century)

Part 4. Confessional-ethnic and political transformations during the Second World War (1939-1945) .................................................103

Part 5. The suffering path of the Church in the second half of the 1940s - 1980s

Part 6. The UGCC as a church-religious institution of independent Ukraine

Part 7. The UGCC in the System of State-Church Relations in Ukraine

Conclusions 187

References 190 


\section{INFORMATION ABOUT THE AUTHORS}

Vehesh Mykola Mykolayovych - Head of the Department of Political Science and Public Administration, Uzhgorod NationalUniversity, Doctor of History, Professor (Introduction, Part 1, conclusions).

Palinchak Mykola Mykhailovych - Dean of the Faculty of International Economic Relations, Uzhgorod National University, Doctor of Political Science, Professor (Part 2).

Marchuk Vasyl Vasyliovych - Head of the Department of Political Institutes and Processes, Vasyl Stefanyk Precarpathian National University, Doctor of History, Professor (Part 4).

Kontsur-Karabinovych Natalia Mykolaivna - PhD in History, Associate Professor of the Department of Social Sciences, IvanoFrankivsk National Technical University of Oil and Gas (Part 5).

Korolko Andriy Zinovijovych - $\mathrm{PhD}$ in History, Associate Professor of the Department of Ukrainian History and Methods of Teaching History, Vasyl Stefanyk Precarpathian National University (Part 6).

Ihor Vehesh - PhD in Political Science, Associate Professor of the Department of Political Science and Public Administration, Uzhgorod National University (Part 3).

Marchuk Nataliya Vasylivna - $\mathrm{PhD}$ in Political Science, Director of the EU Information Center, Associate Professor of the Department of Journalism, Vasyl Stefanyk Precarpathian National University (Part 7). 


\section{INTRODUCTION}

The history of the Greek Catholic Church cannot be considered outside the context of the annals of the statehood and unification of Ukraine in the XX century. Moreover, thousands of its priests and millions of laymen were not only the subject of international politics, but also the subject of ethno-political, religious and spiritual development of the Ukrainian people. The clergymen participated in the pre-election rallies and directly in the activities of the Galician Sejm, were among the founders and activists of "Prosvita", the Shevchenko Scientific Society, "Village Master", "Maslosojuz" and other public and cooperative societies; were elected to the National Council of the Western Ukrainian People's Republic, served as chaplains in the Legion of Ukrainian Sich Riflemen, the Galician Army and the UPA; formed a religious dissidence as the part of the opposition movement of the 1940-80s. Today, the UGCC is an important ethno-cultural factor in the creation of an independent Ukraine.

Therefore, the study of the problem of the relationship between government, society and the church as a social institution in the last century is caused by a number of reasons. First, a public interest to the religion as a poorly understood socio-cultural phenomenon has increased in the last decade in Ukraine. Secondly, changes in the state and political system of Ukraine after 1991 have significantly influenced the role and place of the church in the socio-political and spiritual life of society. Most of the religious organizations, which have been granted a status of a juridical person, have already demonstrated their ability to denounce the positive moral and cultural values to the believers and non-believers, and to actively promote the national revival. Third, establishing a civilized relationship between the authorities and the church will help to promote true democracy in Ukraine. It is because both the state and state-religious structures are interested in constructive dialogue and cooperation.

In this context, a special scientific relevance is concerned with the question of the return of the historical truth about the social role of 
the Greek Catholic Church, its priesthood and the believers in the state-unification process in Ukraine, especially in the era of the Liberation Competitions of the first half of the XX century, as well as in the postwar period of strengthening and collapse of the totalitarian system in the USSR-UkrSSR.

A comprehensive analysis of state-church relations will help to understand the difficult situation that arose in the Ukrainian Orthodox Church of the post-war period. Studying these ambiguous processes will also help to identify inter-denominational misunderstandings in the western region and the ways to overcome them. The civic unity of believers requires their goodwill, tolerance to one another, and a broad ecumenical dialogue, in which, in the opinion of the authors, this concrete work will also take part. As we can see, in addition to purely scientific interest, the urgency of the problem raised in this work is also determined by the practical needs of overcoming some interfaith estrangement and the formation of civil society.

The purpose and objectives of the study are determined by the relevance of the chosen topic, in particular they intend to identify the causes and consequences of confessional and ethnic transformation in the Western Ukrainian region, as well as to generalize the public mission of the Greek Catholic Church in the state-unification process of Ukraine over the last century.

The authors of the study set themselves the following tasks:

- to analyze the state of the scientific development of the topic and the source base of the research;

- to reveal the specifics of confessional-ethnic processes in Austria-Hungary, the nature, mechanism and consequences of the confessional-institutional transformations of Greek Catholicism in Galicia at the end of the XIX - beginning of the XX centuries;

- to show the national and state-making role of the Greek Catholic Church in the development of the Western Ukrainian People's Republic; participation of its members in the activities of the Ukrainian National Council and the State Secretariat, local selfgovernment bodies, service of field chaplains in the Galician Army; 
- to confirm the orientation of the ethno-confessional policy of the authorities of the Second Polish Republic in the Western Ukrainian lands in 1918-1939;

- to research the content and nature of the discussions within the episcopate regarding the state and political orientations of the Church in the interwar period; to show the attempts of Stanislav Bishop H. Khomyshyn to normalize the Ukrainian-Polish relations, which provoked resistance of the majority of national-democratic forces;

- to find out the content and character of the confessionalinstitutive policy of the Nazis in the territory of the General Governorate;

- to show the ecumenical consequences of the decisions of the Lviv "council" in 1946, which initiated the ethno-confessional transformation of the Greek Catholics of the western region in the conditions of the underground in 1940-80's;

- to analyze the policy of the UGCC in solving social and national-cultural problems of the people, preserving its historical memory, forming a system of moral and ethical values;

to find out the role and place of the UGCC in overcoming interstate confrontation in Central and Eastern Europe, harmonizing interethnic relations at the current stage of Ukrainian state-building. 


\section{PART 1. \\ THE UGCC IN THE LIGHT OF HISTORIOGRAPHICAL WORK AND DOCUMENTS}

In the historical development of the human community, religion has always been an important factor in influencing ethnicity and society, it was always showing the ability to accelerate or inhibit ethno-national processes, depending on how closely its confessional orientation matched up with interests of the nation. Religious and ecclesiastical life in Ukraine was also constantly influenced by political and ethno-national factors ${ }^{1}$.

Concerning the role of religion in the Ukrainian ethnogenesis, it should be noted, first of all, that a significant number of theologians consider religion to be a major feature of ethnicity, "which provides peoples with an original ethno-national and ethno-cultural development. One ethnic community is different from another, primarily by confession",

Many ethnologists in the world agree that religion is a stable sign of ethnicity ${ }^{3}$. It should be noted that the identification of the concepts of ethnicity and confessional affiliation, in particular in Russia, was more legitimate than in Ukraine, which has never been monoconfessional. The consequences of this identification have led to acute inter-denominational conflicts, especially during the periods of revival and formation of the statehood.

Actually, church dogma theology itself has no ethno-national color. Thus, Olexii Shuba says that "ethno-national specificity of religion is most manifested in the cult sphere. It is exactly in the religious cult, unlike the other elements of the religious complex, the

\footnotetext{
${ }^{1}$ Реєнт О. П., Лисенко О. П. Українська національна ідея і християнство. Київ: Богданна, 1997. С. 10; Сергійчук В. Нескорена Церква. Київ: Дніпро, 2001. C. 4-40.

${ }^{2}$ Шуба О. Релігія в етнонаціональному розвитку України. Київ: Криниця, 1999. C. 21.

${ }^{3}$ Бочковський О. Вступ до націології. Генеза. 1996. № 1(4). С. 90.
} 
imprint of ethnic characteristics is the most noticeable. Depending on the mentality of the people, the same religious actions or rituals may have different shades. Features of national culture, traditions, folklore heritage put their own imprint on the religious cult ${ }^{4}$.

The successes of Christianization of Ukraine-Rus', its acquisition of the national life, religious outlook, Mykhailo Hrushevsky justified first of all by the fact that the Orthodox Church was filled with ethnonational content, it expanded and approached the needs, especially the needs of the peasantry 5 .

In its thousand-year history, Ukraine has repeatedly lost its independence. The neighboring empires, especially the Russian empire, extending their possessions to Ukraine, first of all tried to eliminate the ethno-national features of the Ukrainian Church. Emperor Peter the First at the turn of XVII-XVIII centuries initiated this process, and it actually lasted to this day. It should be noted that in the multi-ethnic and poly-denominational Romanov Empire, Orthodoxy was state-owned and the Church served the imperial authority ${ }^{6}$. After the Metropolitanate of Kyiv was subordinated to the Moscow Patriarchate in 1686, there began a process of elimination of national religious and ecclesiastical features of the Dnieper Ukraine, annexed to the Russian Empire. It referred to the ordinances and traditions of the Church that had developed over the centuries in its activities, religious practices, religious-social matters, and so on. For reasons of national interest, "the national and church specificity of Ukraine has become the object of painful and irreconcilable reaction not only by church authorities, but also by the state, acquiring in many cases a political color"7. The Moscow Patriarchate was particularly active, using measures to unify the Church and eliminate its identity ${ }^{8}$.

\footnotetext{
${ }^{4}$ Шуба О. Релігія в етнонаціональному розвитку України. Київ: Криниця, 1999. C. 27.

5 Грушевський М. 3 історії релігійної думки на Україні. Київ: Освіта, 1992. С. 50-52.

${ }^{6}$ Бердяев М. Судьба России. Москва, 1990. С. 7.

7 Історія релігії в Україні / За ред. А.М. Колодного і П.Л. Яроцького. Київ: Знання, 1999. С. 223.

${ }^{8}$ Лисяк-Рудницький І. Нариси з історії нової України. Львів, 1991. С. 211. 
Against the attacks of Moscow Orthodoxy and Polish Latin Catholicism, the Kyiv Church saw the salvation of ethnic and religious identity in union with Rome. It was also motivated by the geopolitical position between the East and the civilized West and between the Catholic West and Eastern Islam, by the eternal attraction to the Ecumenical Church in the person of the Apostolic See. The Union of Brest between Kyiv Church and Rome marked a new period in the religious life of the Ukrainian community. The established Ukrainian Greek Catholic Church, in the form of a Western Catholic Church, maintained its ethno-national identity, above all its rite, language, traditions, and most importantly, its independence from Moscow and Warsaw, which ensured its three centuries of fruitful existence ${ }^{9}$.

Thus, the Russification of tsarist Russia and the Caesaro-papism of its Orthodox Church, which claimed the role of "Third Rome", the policy of Polonization of the occupied Ukrainian lands by Poland, and the desire of the Latin Church to make their population a catholic one - were defeated in the Ukrainian ethnic territory, where the believers began to realize their ethno-national identity not through Orthodoxy, but through Greek Catholicism. After the Union of Brest, the interconnection of ethnicity and religion took on a new meaning ${ }^{10}$.

At the same time, many historians and theologians claim that the union "caused a deep religious crisis that went beyond the XVI century, has sharply affected the whole history of the Ukrainian people, provoked long-lasting church and national conflicts"11.

National traits of religions are formed as a result of the mutual influence of specific living conditions of peoples, their national spirituality. Modern researchers A. Kolodnyi, P. Yarotsky, O. Rejent, O. Lysenko, O. Shuba, S. Holovashchenko, I. Paslavskyi state that the religiosity of each nation is peculiar because it has its specific forms of expression, which are the property of the ethnic group in its historical genesis. The religious factor was often decisive in the

\footnotetext{
${ }^{9}$ Головащенко С. Історія християнства. Київ: Либідь, 1999. С. 251.

${ }^{10}$ Реєнт О. П., Лисенко О. П. Українська національна ідея і християнство. Київ: Богданна, 1997. С. 13.

11 Історія релігії в Україні / За ред. А.М. Колодного і П.Л. Яроцького. Київ: Знання, 1999. С. 617.
} 
process of ethno-formation and ethnic integration, although Ukraine is characterized by certain peculiarities due to its polyconfessionality, when the national idea was a priority.

Let us pay attention to the concept of this problem by the Russian Orthodox Church, which still holds a significant place among the denominations of Ukraine. ROC theologians argue that religion is the main and most important feature that defines the essence of ethnicity and provides the nation with original ethno-cultural development. Thus, one ethnic community differs from another, first of all, by confessional affiliation, that is, the religious factor is fully identified with the national one ${ }^{12}$.

It should be noted that in spite of the stateless existence and domination of foreign regimes, the ideas of sameness of religious and national identity were weaker in Ukraine, because it was not monoconfessional. In the Dnieper Ukraine, in particular, there were opinions about the inadmissibility of the above-mentioned Great Rus' idea for the Ukrainian national matter, because it strengthened the domination of the Russian autocracy. M. Drahomanov categorically emphasized that "the identification of any nationality with religion is an absurd, a principled and practical one"13.

At the same time, in our view, it would be a great mistake to ignore religion as one of the important attributes of a nation. Therefore, one should agree with scholars who regard religion as an integral element of ethnicity. "Society becomes an ethnic group," emphasizes modern Ukrainian scientist E. Heller, "if it is integrated on the basis of such factors as... language, customs, folklore, religion" ${ }^{\prime 14}$. Ethnologist O. Bochkovskyi ${ }^{15}$ holds the same opinion. Despite centuries-old statelessness, national, cultural and spiritual annihilation by the tsarist, and later communist regimes, the

12 Шуба О. Релігія в етнонаціональному розвитку України. Київ: Криниця, 1999. C. 21.

13 Драгоманов М. Чудацькі думки про українську національну справу. Літературно-публіцистичні прачі: У 2-х томах. Т. 1. Київ, 1970. С. 360.

${ }_{14}$ Геллер Е. Нація-етнос. Мала енциклопедія етнодержавознавства. Київ: Генеза; Довіра, 1996. С. 124.

${ }^{15}$ Бочковський О. Вступ до націології. Генеза. 1996. № 1(4). С. 90. 
Ukrainian nation has shown a unique ability to preserve ethnic identity.

Considering at a different angle the correlation between religious and national factors in the development of the Ukrainian ethnic group, A. Kolodnyi noted that religion and the nation as absolutely important social phenomena do not play a "decisive role in the development of ethnic communities, national consciousness". At the same time, it is emphasized that, depending on specific historical conditions, religion "can act as an important and, sometimes, decisive mode of ethnic formation" " The original opinion was expressed by the scientist from Ternopil L. Kubayevskyi, who from the standpoint of philosophical and political synthesis considered the interrelation of the Ukrainian national idea and the religious idea. He asserts that the ultimate goal of the Ukrainian national idea is to build a Ukrainian united state, and, therefore, a goal of the religious idea is to build a nationwide church $^{17}$.

Thus, the religiosity of Ukrainians is the result of a centuries-old historical process of interaction between religion, society and ethnic groups. Due to these and other circumstances, many contemporary scholars of religion believe that religion has not always been a determining factor in national revival and ethnic integration. Therefore, Ukraine has become poly-confessional and it can achieve national unity only if it adheres to the principle of ideological and religious pluralism ${ }^{18}$.

The historiography of the problem can be divided into three periods: 1) the first half of the $\mathrm{XX}$ century; 2) the time of the catacomb existence of the UGCC (1946-1989); 3) the modern period (from the legalization of the church in 1990), during which separate theme plots were elaborated by the Ukrainian and foreign researchers.

16 Історія релігії в Україні / За ред. А.М. Колодного і П.Л. Яроцького. Київ: Знання, 1999. С. 571.

17 Медвідь Ф., Коваленко А. Дослідження ролі релігії у національному самовизначенні держави. Київська Церква. 2000. № 1. С. 131.

18 Статистика релігій України. - 1992-2002; Соціологічні дослідження 2001 року релігійності, конфесійної належності, довіри Богу, Церкві та духовенству. Релісійна панорама. 2002. № 3. С. 41-51. 
In the first period, especially during the twenty years of the interwar period, the first ecclesiastical-analytical works appeared, the revision of which allowed a Diaspora's scholar Olexandr Ohloblyn to assert at that time the formation of Ukrainian church historiography as a separate scientific discipline ${ }^{19}$. In particular, reviews of churchhistorical works were an integral part of the historiographic studies of the scientists of Shevchenko Scientific Society and the Ukrainian Society of Bibliophiles in Lviv, such as Ivan Kalynovych, Dmytro Doroshenko, Dmytro Bachynsky, Myron Kordub, Yevhen Pelensky, Mykola Chubatyi ${ }^{20}$. These historians, as a rule, generalized the causes, course and consequences of the transition of the Rus' eparchies to the Union and were interested in their social status during the period of foreign domination, in particular in the Commonwealth of Poland, the Russian Empire, Austria-Hungary. Increased attention was paid to prominent ecclesiastical figures in not only the Greek Catholic Church (J. Rutsky, A. Sheptytsky), but also in the Orthodox Church (M. Smotrytsky, J. Shumlyansky), as well as to the religious writing and printing in Pochaiv, Lviv, and Zhovkva, to the education of the population. The Greek-Catholic scholars rightly noted that Christianity spread to our territories both from the East and from the West, giving grounds for the formation of the identity of Ukrainian Christian culture. Special historiographic and bio-bibliographical studies of Volodymyr Bidnov, Volodymyr Zaikin, Mykola Andrusyak, Ivan Krevetsky, as well as studies of the priests Ivan Krutij-Vyhorynsky, Roman Lukanj and others were also published $^{21}$.

19 Оглоблин О. Українська церковна історіографія. Украйнський історик. 1969. № 1-4 (57-60). C. 12-29.

20 Заїкін В. 3 сучасної української церковної історіографії. ЗапискиЧСВВ. Львів, 1927. Т. 2. Вип. 1-2. С. 425-431; Калинович І. Бібліографія українознавства за 1914-1923 рр. Вип. 1: Історія України. Львів, 1924. 59 с.

${ }^{21}$ Біднов В. Дослідження церковної історії в православних країнах. Крем'янець, 1931. 20 с.; Заїкіни А. і В. Матеріали до бібліографії української історії 19301931. Записки ЧСВВ. Львів; Жовква, 1936. Т. 6. Вип. 1-2. С. 338-394; Кревецький I. Видавництво Чину св. Василія Великого в Жовкві. Альманах Василіянських богословів. Кристинопіль, 1933. С. 35-39; Крутій-Вігоринський I. Видавництво оо. Василіян у Жовкві. Календар «Місіонаря». Жовква, 1932. С. 67-72; Лукань Р. Список книжок Видавництва ЧСВВ в Жовкві. Записки ЧСВВ. Рим, 1967. Т. V. С. 389-420. 
A significant impetus to the study of church history was the foundation in 1923 of the Theological Scientific Society in Lviv. Ecclesiastical and historical works of the members of this society were published in the quarterly edition "Theology". An important center of church and historical studies was the Greek Catholic Theological Academy in Lviv (founded in 1927) ${ }^{22}$.

Church-archeographic research was initiated by: Archive of the History of Union (created in 1928 with the assistance of Metropolitan A. Sheptytsky); Stauropegion Institute; Basilian Science Center Central Basilian Archive and Library, collection "The Notes of OSBM" 23 .

It is clear that the concepts of the majority of researchers of this era express a confessional vision of the problem - proving the unifying character of the Ukrainian Church. However, there were some differences in the historical interpretation of the church union and its lessons by secular and spiritual scholars. The first group, as a rule, highlighted national-state priorities, assessing the culturalChristian (oriental and occidental) traits of the Ukrainian mentality. Theologians, while rejecting national priorities, treated the processes of unification primarily in the religious-confessional key.

Ukrainian Soviet historiography developed under censorship prohibitions, which significantly restricted the ability of researchers to choose and interpret the subject. Soviet historians, philosophers, and religious scholars generally treated the documents relating to church and religious life in the western region of Ukraine in a biased way: the emphasis was on showing the "expansion" of the Vatican,

22 Тиміш Л. І. Церковно-історичні дослідження у міжвоєнний період. Iсторія релігій в Украӥні. Праці Х Міжнар. наук. конф. (Львів, 16-19 травня 2000 р.). Львів, 2000. Кн. 1. С. 375-378; іiі ж. Наукові семінари Миколи Чубатого в Грекокатолицькій Богословській академії (до питання про розвиток церковноісторичних досліджень у міжвоєнному Львові. Вісник Київського університету. Iсторія. Київ, 2001. Вип. 58. С. 66-70.

23 Тиміш Л. І. Археографічна діяльність наукових осередків міжвоєнного Львова (до проблем формування архівно-джерельної бази дослідження історії української Церкви). Дрогобицький краєзнавчий збірник. Вип. V. Дрогобич, 2001. С. 222-235; iii ж. Дослідження проблем 3 історії української Церкви вченими Ставропігійського інституту (міжвоєнний період). Історія релігій в Україні. Праці ХІІІ-Ї міжн. наук. конф. (Львів, 20-22 травня 2003 р.). Кн. 1. Львів, 2003. С. 574-578. 
exposing the "anti-people" politics of the Greek Catholic hierarchs, their rejection of the left radical movement, servicing the German Nazi regime. Soviet historiography evaluated the church-historical heritage negatively: it ignored the national-cultural initiatives of the church, its social policy, activity for the monuments preservation, its environmental, economic and cooperative activities. However, the monographs, published at that time, and especially the collections of documents, contained certain specific historical information, which did not lose its relevance and informative nature to this day.

A notable representative of the Soviet anti-clerical thought can be considered Yaroslav Halan (alias "Volodymyr Rosovych"), who published on April 8, 1945 in the Lviv newspaper "Free Ukraine" an article "With a Cross or a Knife" (the same year it was published as a separate brochure). A recent member of KPZU (Communist Party of Western Ukraine) accused the "Uniate Church" and its ministers of forcibly displacing the Orthodox faith in Ukrainian lands. In June 1948, the regional newspaper "Transcarpathian Ukraine" published his article "Twilight of Alien Gods", which was directed against the forbidden church and its deceased Metropolitan A. Sheptytsky. Criticizing the UGCC, Moscophile Jaroslav Halan confronted it with the Russian Orthodox Church, its clergy as consistent fighters for the return of Western Ukrainians to the ancestral faith ${ }^{24}$.

Only during Gorbachev's "perestroika" the interest of scientists to the problems of national and cultural life of the Western Ukrainians increased. Prohibited studies, which were stored for years in special funds of libraries and archives, became available.

For a deeper theoretical understanding, contemporary scholars have begun to turn to generalizing works on the history of Christianity and the Church in Ukraine, most notably to the works written by Stepan Tomashivsky ${ }^{25}$, Ivan Ohienko (Metropolitan

\footnotetext{
24 Пащенко В. Ярослав Галан. Міфи і факти біографії і творчості. Наукові записки Тернопільського державного педагогічного університету імені Володимира Гнатюка. Серія: Історія. Тернопіль, 2002. Вип. 2. С. 61-73.

${ }^{25}$ Історія Церкви на Україні (від найдавніших часів до монгольської навали). Жовква: Місіонер, 1932.
} 
Ohienko) $^{26}$, Mykola Chubatyi ${ }^{27}$, Matviy Stakhiv ${ }^{28}$, Hryhoryi Luzhnytskyi $^{29}$, Yurij Fedoriv ${ }^{30}$ and the others, which had been published abroad or in the Western Ukraine before 1939. They have already been the subject of historiographic reviews, so let us dwell on the achievements of contemporary historiography of the problem.

The textbook "History of Religion in Ukraine" (Kyiv, 1999), edited by A. Kolodnyi and P. Yarotskyi, outlines the "formation of Greek Catholicism as a factor of national awakening" of the Ukrainians, analyzes the general tendencies of development of the Greek Catholic Church in the XVII - XX centuries ${ }^{31}$.

Such religious scholars as father B. Hudziak, M. Tchaikovsky, N. Stokolos, O. Turiy, O. Hryniv in the collective work "Catholicism", published in 2001 under the general editorship of P. Yarotskyi, Doctor of Philosophy, as the fourth volume of the tenvolume "History of Religion in Ukraine" (Kyiv, 1996-2002), outlined ethno-political orientations of the Greek Catholic Church in the XVII - XX centuries. The book shows the course and consequences of the violent liquidation of the Uniate Church under the rule of the Russian Empire in the Chelm Land and Podlachia, exacerbation of Greek Catholic and Roman Catholic ceremonial-national conflicts in Galicia, ethno-confessional transformations of the Greek Catholics in Transcarpathia in the XIX century, and also the dramatic events of the XX century - dynamic development of the church and at the same time the limitation of its activity, in accordance with the VaticanPolish concordat, only within Galicia; ethno-confessional transformation of Greek Catholics in Lemkivshchyna; introduction by a Roman Catholic Church of a new union in the Western Ukrainian

\footnotetext{
${ }^{26}$ Огієнко I. Українська Церква: Нариси 3 історії Української православної церкви. Прага, 1942 (2-евид.: Київ: Абрис, 1993).

27 Чубатий М. Історія Християнства на Руси-Україні. В 2-х т. Рим; Нью-Йорк: Укр. Католицький ун-т ім. Св. Климента папи, 1965-1976.

${ }^{28}$ Стахів М. Христова Церква в Україні (988-1596). Нарис історії католицької Церкви та аналіз охрещування в ній інтересу Риму, Царгороду, Варшави і Москви св. В. Великого. Рим, 1985.

29 Лужницький Г. Українська церква між Сходом і Заходом: нарис історії Української Церкви. Філадельфія: Провидіння, 1954.

${ }^{30}$ Федорів Ю. Історія Церкви в Україні. Люблін, 1991.

${ }^{31}$ Історія релігії в Україні. Київ, 1999. С. 608-625.
} 
lands without participation of the Greek-Catholics in this action; recovery of the Orthodox churches by the Polish authorities and the attempts of Polonization of the Orthodox Ukrainians in the interwar period in Volyn, Polissya, Chelm Land and Podlachia; and finally, the repression of the Soviet totalitarian regime against the UGCC and its believers in 1940-80's.

The phenomenon of Ukrainian national and cultural revival of the XVI - XVII centuries, which led to the Union of Brest, became the object of scientific research of Fr. B. Hudziak. The researcher critically reinterpreted the Ukrainian and world historiography of the genesis, content and results of the union, which became a fundamental turning point in the history of the Kyiv Church, the consequences of which have caused a deep resonance in the religious, cultural and political life of Eastern Europe and have been influencing the inter-confessional relations of the Christian world for a long time ${ }^{32}$.

Monograph, written by Bishop of the Ukrainian Church in Argentina A. Sapelyak (in 1997 he returned to Ukraine), "Kyiv Church in the Slavic East" (Buenos Aires; Lviv, 1999) reproduces a picture of an ecumenical-unification process on a base of a large documentary from the archives of the Apostolic See in the Kyiv Church; it also emphasizes the merits of its founders - Veliamyn Rutsky, Andrey Sheptytsky and Josyf Slipyj ${ }^{33}$.

A. Pashuk's monograph "The Ukrainian Church and Independence" (Lviv, 2003) examines the political role of Christian Churches in the national and cultural life of Ukraine and the Ukrainians. The Lviv philosopher focused on religious and denominational relations in the Middle Ages and in the modern period. A. Pashuk reasonably unmasks Soviet fakes about the consequences of the Union of Brest (as if it was done by the hands of Poles and polonized Germans, colonists-Catholics in Lviv).

Contemporary historiography of the problem can hardly be imagined without issues of "Kovcheh" ("Ark") - the "scientific

\footnotetext{
32 Гудзяк Б. Криза і реформа: Київська митрополія, Царгородський патріархат і генеза Берестейської унії. Львів: Інститут історії церкви ЛБА, 2000. 426 с.

${ }^{33}$ Сапеляк А. Київська Церква на слов'янському сході: Канонічно-екуменічний аспект. Буенос-Айрес; Львів, 1999. С. 8.
} 
collection on church history", published since 1993 in Lviv by the Institute of the Church History of the Ukrainian Catholic University (until 2002 - Lviv Theological Academy). The institute has organized a number of scientific conferences, including a series of "Brest readings", dedicated to the 400th anniversary of the Union of Brest. Actually, the articles in the aforementioned collection were the results of its research projects on ancient and recent history ${ }^{34}$.

Among contemporary Ukrainian scholars, Oksana Hayova took the largest part in studying the spiritual heritage of Metropolitan Sheptytsky; she organized the archives of the Sheptytsky family and co-authored the multi-volume publication "Metropolitan Andrey Sheptytsky: Life and Activity. Documents and Materials", which has been published in Lviv since 1995.

The visitation documentation of the Church and the problem of its study were the object of archeographic generalizations of Igor Skochylyas ${ }^{35}$.

Some aspects of the problem have been covered in the religious studies on the ecclesiastical history of the regions. A successful attempt to summarize the history of the UGCC in Bukovina was a small sketch by Stepan Karachko, published in the "Catholic Annual" of 1996, which was prepared by the Publishing House of the Kyiv-

\footnotetext{
34 Вл. Любомир (Гузар). Екуменічна місія Східних Католицьких Церков у баченні митрополита Андрея (Шептицького). Ковчег. Ч. 2. Львів, 2000. C. 189-212; Расевич В. Митрополит Андрей (Шеитицький) i проблема національно-політичної консолідації українців (1900-1918 роки). Ковчег. С. 212-223; Кравчук А. Християнська етика підчас німецької окупації Галичини, 1941-1944: митрополит Андрей (Шептицький) про солідарність, опір владі та захист святості життя. Ковчег. С. 224-272; Глистюк Я. Два листи о. Мирослава Івана Любачівського до митрополита Андрея (Шептицького) 3 1941-1942 років. Ковчег. Ч. 3. Львів, 2001. С. 507-510; Гуркіна С. Митрополит Андрей (Шептицький) в період німецької окупації Галичини: найновіша історіографія питання (1989-2000 роки). Ковчег. С. 556-565; Авакумов Ю. Митрополит Андрей (Шептицький) і проблеми церковної єдності в Росії. Ковчег. Ч. 3. Львів, 2003. С. 101-114.

35 Скочиляс I. Дослідження візитаційної документації Львівської єпархії у Галичині в другій половині ХІХ - першій половині ХХ століття. Ковчег. Ч. 3. Львів, 2001. С. 470-489.
} 
Mohyla Academy ${ }^{36}$. The two-volume work "Essays on the History of the Church in Transcarpathia" by the famous theologian Atanasius V. Pekar summarizes the socio-cultural and scientific work of the clergy, analyzes the activities of priestly societies and educational institutions (Mukachevo Theological School, Uzhgorod and Presov Seminaries). Much attention was paid to the charitable activity of the church in the first half of the XX century - the construction of eparchial hostels for the gymnasium students, orphanages and people's kitchens, the economic education of peasants, the conduction of anti-alcohol campaigns, and the musical and artistic education of young people ${ }^{37}$.

A series of publications appeared attempting to reproduce the participation of clergymen in the cooperative movement of the late XIX - first half of the XX centuries, including the creation in 1904 by the initiative of Father Ostap Nyzhankovsky, in the village Zavadiv (Stryi region) of the first Ukrainian Dairy Union, which became a base for the powerful "Regional Dairy Economic Union"38.

Researchers do not miss the complex and ambiguous aspects of the life of the church in the interwar period of the XX century. M. Moskalyuk analyzed the achievements and failures of the Christian social movement ${ }^{39}$. The role and place of the UGCC in the political system of the Second Polish Republic was covered by V. Pereveziy ${ }^{40}$, V. Marchuk ${ }^{41}$ and I. Pylypiv ${ }^{42}$. O. Yehreshiy revealed

\footnotetext{
${ }^{36}$ Карачко С. Українська Греко-Католицька Церква на Буковині. Католицький щорічник. 1996. Київ, 1996. С. 78-80.

37 Пекар А. Нариси історії Церкви Закарпаття. Т. 2. Рим; Київ, 1997. С. 172-231, 292-305, 381-431.

38 Історія споживчої кооперації України / Кер. авт. колективу С. Гелей. Львів, 1996; Андрій Палій - будівничий та керманич «Маслосоюзу». Статті, спогади, листи. / Упор. Р. Матейко. Тернопіль, 2001; Мазур М., Скробач В. Кооперативний буквар. Івано-Франківськ, 1995.

39 Москалюк М. Українська католицька народна партія і проблема польськоукраїнського порозуміння. Українсько-польські відносини в Галичині у XX cm. Івано-Франківськ, 1997; його ж. Український християнсько-суспільний рух Галичини в 20-х pp. XX ст. Автореферат дис. на здобуття наук. ступ. канд. політ. наук. Київ, 1998.

40 Перевезій В. Українська греко-католицька церква в політичній структурі східногалицького суспільства в 20-30-х pp. ХX століття. Вісник Прикарпатського університету. Філософські і психологічні науки. 1999. № 1;
} 
the reasons and essence of ideological differences between the UGCC rulers, he determined the prerequisites for the creation by Bishop H. Khomyshyn of an Occidental ideological course and a conservative program of Ukrainian-Polish understanding of the $1930 \mathrm{~s}^{43}$.

Mykola Kuhutyak, considering the ethno-political origins and historical role of the Western Ukrainian national democracy in the first quarter of the XX century, cites numerous facts of indirect or direct involvement in the maelstrom of this political movement of the Greek Catholic clergy, which sought to consolidate and harmonize the nation-state's community of the region ${ }^{44}$. Stepan Kacharaba's monograph "Emigration from Western Ukraine (1919-1939)" (Lviv, 2003), on the basis of official censuses and recent studies of foreign and Ukrainian authors, specifies the population of the region by religion, shows the social status of the Greek Catholics of historical Galicia.

Studies on the history of the Church on the Polish-Ukrainian border, in particular in Nadsannia, have been intensified. Many special investigations have been published in the three-volume collection of scientific works and materials "Przemyśl and Przemysl Land over the Ages" (Przemysl; Lviv, 1996-2003), prepared by the I. Krypiakevych Institute of Ukrainian Studies of the National Academy of Sciences of Ukraine together with the Shevchenko Scientific Society in Poland. The readers will be particularly

Переверзій В. Греко-католицька церква в умовах українсько-польської конфронтації 20-30-х рр. XX ст. Автореферат дис. на здобуття наук. ступ. канд. іст. наук. Київ, 1998.

${ }^{41}$ Марчук В. Українська Греко-Католицька Церква. Історичний нарис. ІваноФранківськ, 2001; Марчук В. Греко-католики в Другій Речі Посполитій: суспільний чин та конфесійно-територіальний устрій. Галичина. 2001. № 5-6.

42 Пилипів І. Державотворча політика греко-католицької церкви у суспільнополітичному житті Західної України 20-30 років ХХ ст. Украӥнське державотворення: уроки, проблеми, перспективи. Ч. 1. Львів, 2001.

${ }^{43}$ Єгрешій О. Єпископ Григорій Хомишин і питання українсько-польського порозуміння 1904-1939 pр. Івано-Франківськ, 2001; Сгрешій О. Взаємовідносини митрополита Андрея Шептицького і єпископа Григорія Хомишина. Галичина. 2001. № 5-6. С. 315-321.

${ }^{44}$ Кугутяк М. Історія української націонал-демократії. 1918-1929. Т. 1. Київ; Івано-Франківськ, 2002. Т. 2, 2004; Кугутяк М. Галичина: сторінки історії. Івано-Франківськ, 1993. С. 84-99. 
interested in the articles on the organization and territorial structure of the Przemysl Eparchy ${ }^{45}$, the activities of the Przemysl Cathedral Chapter $^{46}$, the Theological Seminary ${ }^{47}$, the Cantor' Institute ${ }^{48}$ and the parish schools ${ }^{49}$, the history of the Mitre of the Przemysl Bishops ${ }^{50}$, as well as the social rank and life of Bishops Hryhoriy Lakota and Josaphat Kotsylovsky.

Kyiv archivist Heorhiy Papakin attempted to reconstruct Hetman Pavlo Skoropadskyi's (1918) attitude to Metropolitan Andrey Sheptytsky, in whom he saw the future patriarch of the united Ukrainian Church. H. Papakin analyzed an unpublished correspondence of Galician clerical figure O. Nazaruk with P. Skoropadskyi, that recreates the preparation of the Metropolitan's meeting with hetman in 1938-1939, which did not take place because of the tragedy of the Carpathian Ukraine and the outbreak of a new world war ${ }^{51}$.

45 Стемпень С. Організація та територіальна структура Перемиської грекокатолицької єпархії за владицтваєпископа Йосафата (Коциловського) ЧСВВ (1917-1946). Перемишль $i$ Перемиська земля протягом віків / За ред. С. Заброварного; упор. С. Заброварний, М. Литвин, Ф. Стеблій. Перемишль; Львів, 2003. С. 195-233.

${ }^{46}$ Павлище П. 3 історії Перемиської капітули. Перемишль і Перемиська земля протягом віків / За ред. С. Заброварного; упор. С. Заброварний, М. Литвин, Ф. Стеблій. Перемишль; Львів, 2003. С. 167-187.

${ }^{47}$ Васьків Р. Блаженний Єпискои-Новомученик Кир Григорій Лакота як ректор першої повної духовної семінарії в Перемишлі та його праця в інших інституціях. Перемишль $і$ Перемиська земля протягом віків / За ред. С. Заброварного; упор. С. Заброварний, М. Литвин, Ф. Стеблій. Перемишль; Львів, 2003. С. 155-156.

48 Ясіновський Ю. Дяко-учительський інститут у Перемишлі. Перемишль $i$ Перемиська земля протягом віків / За ред. С. Заброварного; упор. С. Заброварний, М. Литвин, Ф. Стеблій. Перемишль; Львів, 2003. С. 249-259.

49 Дзьобай О., Тимочко М. Парафіяльні школи та підручники, видані в Перемишлі українською мовою (кінець XVIII - перша половина XIX ст.). Перемишль і Перемиська земля протягом віків / За ред. С. Заброварного; упор. С. Заброварний, М. Литвин, Ф. Стеблій. Перемишль; Львів, 2003. С. 260-272.

${ }^{50}$ Білий Б. Митра Перемиських владик або так звана «Корона Данила»: міфи і факти. Перемишль і Перемиська земля протягом віків / За ред. С. Заброварного; упор. С. Заброварний, М. Литвин, Ф. Стеблій. Перемишль; Львів, 2003. C. 245-248.

51 Папакін Г. Павло Скоропадський: патріот, державотворець, людина. Історико-архівні нариси. Київ, 2003. С. 117-134. 
In the focus of the researchers (B. Kazymyr, M. Marunchak, P. Poniatyshyn, P. Khomyn, and L. Tsehelskyi), mainly in Diaspora, there were missionary visits of Metropolitan A. Sheptytsky to the North and South America in the interwar period ${ }^{52}$.

Jaroslav Zaborovskyi dedicated an essay and a selection of theological works and photos to this remarkable figure ${ }^{53}$. The book focuses on the ecumenical position of Metropolitan Andrey, his foreign policy and financial and economic activities in defense of the enslaved Western and Eastern Ukrainians; it also proves his initiation of a series of protest actions and grain collection for the starving people in the UkrSSR.

The activity of the Church on the monument protection (museums, scientific expeditions, etc.) was the object of study of Lviv religious scholar and archaeologist Mykola Bandrivsky ${ }^{54}$. The mentioned topic was also in the field of interest of precarpathian scientist Ihor Koval ${ }^{55}$.

The first attempts were made to generalize the organizational and financial support by the church of public structures of social

52 Казимира Б. Митрополит Андрей Шептицький та канадські українці. Пропам'ятна книга оо. Василіян у Канаді. Торонто, 1953. С. 97-149; Марунчак М. Митрополит Андрей Шептицький на Заході 1920-1923. Вінніпег; Едмонтон, 1981; Понятишин П. 3 моїх споминів. Митрополит Андрей Шептицький в Америці. Украӥнці у Вільному світі. Ювілейна книга Українського Народного Союзу, 1894-1954. Джерсі Сіті; Нью-Джерсі, 1955. С. 19-36; Понятишин П. Митрополит Андрей Шептицький в Америці. Слуга Божий Митрополит Андрей Шептицький в Америці. Філадельфія, 1997. С. 110-123; Хомин П. Митрополит Андрей Шептицький як Апостольський Візитатор для українців у Полудневій Америці. Богословія. Львів, 1926. № 1. С. 207-210; Цегельський Л. Митрополит Андрей Шептицький. Філадельфія, 1937.

53 Митрополит Андрей Шептицький. Матеріали і документи (1865-1944рр.). Друге доп. вид. / За ред. Я. Заборовського. Львів; Івано-Франківськ, 1995.

${ }^{54}$ Бандрівський М. Митрополит Андрей Шептицький - меценат української археології. Берестейська унія (1596-1996). Львів, $1996 . \quad$ С. 204-207; Бандрівський М. Археологічна діяльність Ісидора Шараневича (1829-1901). Постаті української археології: Матеріали $i$ дослідження 3 археології Прикарпаття і Волині. Вип. 7. Львів, 2000. С. 95-97; Бандрівський М. 3 історії досліджень Успенського собору в Галичі. Записки НТШ. Т. CCXXV. Львів, 1993. С. 393-405; Бандрівський М. Пам'яткоохоронна діяльність Церкви в контексті національно-культурного руху в Галичині (кінець XIX - XX ст.). Автореферат дис. на здобуття наук, ступеня канд. іст. наук. Львів, 2001.

55 Коваль I. Ярослав Пастернак - основоположник української церковної археології. Нова зоря. 1999. 26 травня. 
guardianship in the interwar period - tutelary societies, orphanages and burials, which, despite the difficult internal conditions of occupation, tried not only financially but also morally to help the deprived western Ukrainian society ${ }^{56}$.

The scientific, creative and socio-political activity of the priesthood in the educational field and in the representative bodies of the power in the XIX - the first half of the XX century has been repeatedly covered in numerous historical and local lore publications by P. Arsenych ${ }^{57}$, V. Poliek ${ }^{58}$, V. Hrabovetsky ${ }^{59}$.

Separate facets of the ethno-cultural and social mission of the church, in particular, the experience of its Christian upbringing of a citizen-patriot in the 1920's and 1930's are covered in the historical and pedagogical explorations, published in the "Scientific Notes" of the National University "Ostroh Academy" 60 . This experience is most fully summarized by Liubov Henyk. The researcher reproduces the system of national-religious education in youth societies "Sich", "Sokil", "Plast", "Mary squads", in private and public institutions of various levels - public schools, gymnasiums, lyceums, seminaries, civic and religious universities ${ }^{61}$. The same problems were also

\footnotetext{
56 Гнот С. І. Греко-католицька церква і організація суспільної опіки Галичини (1921-1939 рр.). Актуальні проблеми державного управління. Вип. 6. Львів, 2001. С. 299-309.

57 Арсенич П. Греко-католицькі священики в національних змаганнях українців Галичини. Нова зоря. 1991. Ч. 5-6.

58 Полєк В. Духовна освіта на Прикарпатті. Нова зоря. 1991.Ч. 33-34; його ж. Священик-меценат. Нова зоря. 1991. Ч. 25-26.

59 Грабовецький В. Сторінки літопису Івано-Франківського Катедрального Собору Святого Воскресіння. Івано-Франківськ: Нова Зоря, 1999. 80 с.; Грабовецький В. Андрей Шептицький і Станіславівщина. Галичина. 1994. 21 жовтня.

60 Кіндрат К., Кіндрат К. Андрей Шептицький - праведник України. Християнські ијінності: історія і погляду третє тисячоліття. Зб. наук. записок Національного університету «Острозька академія». Т. VI. Острог, 2002. С. 26-31; Чепіль М. Християнська педагогіка Юліана Дзеровича. Християнські иінності: історія $i$ погляду трете тисячоліття. Зб. наук. записок Національного університету «Острозька академія». Т. VI. Острог, 2002.. С. 439-446.

61 Геник Л. Я. Релігійно-моральне виховання молоді в навчальних закладах Східної Галичини кінця XIX - початку XX ст. Івано-Франківськ: Плай, 2000. C. 199-201.
} 
indirectly considered by B. Stuparyk, V. Motsyuk, H. Bilavych and B. Savchuk, and others ${ }^{62}$.

Oksana Surmach ${ }^{63}$, a Lviv researcher, tried to analyze the complexity of church and religious life during the Nazi occupation. Among the groundbreaking works dedicated to the Second World War, we have to mention the monograph by O. Lysenko "Church Life in Ukraine. 1943-1946" (Kyiv: Institute of History of Ukraine of the National Academy of Sciences of Ukraine, 1998), which for the first time in national historiography generalizes the problem of relations between church and state structures in the UkrSSR after the liberation of its territory from the Nazis until $1946^{64}$.

Olexandr Rejent and Olexandr Lysenko analyzed the littleresearched problem of interaction between religious and national spheres not only at the level of social consciousness, but also in the context of concrete-historical events of the first half of the XX century, first of all, in 1920-1940s. The authors considered the religious aspect of the Ukrainian national idea, paying particular

62 Ступарик Б. Шкільництво Галичини (1772-1939). Івано-Франківськ: Акорд, 1994; Ступарик Б., Моцюк В. Ідея національної школи та національного виховання в педагогічній думці Галичини (1772-1939). Коломия: Вік, 1995; Білавич Г., Савчук Б. Товариство «Рідна школа» (1881-1939). Івано-Франківськ: Лілея-НВ, 1999; Янів В. Нариси до історії української етнопсихології. Мюнхен: В-во УВУ, 1993.

63 Сурмач О. Греко-Католицька Богословська Академія в роки німецької окупації (1941-1944). Наукові зошити історичного факультету Львівського державного університету. Львів, 1999. Вип. 2. С. 185-187; Сурмач О. Внутрішньодержавне життя УГКЦ в роки німецької окупації (1941-1944). Питання історії Украӥни. Чернігів, 2000. Т. 4. С. 175-179; Сурмач О. Польськоукраїнський конфлікт і УГКЦ в часи німецької окупації. Украйнське релігіознавство. Київ, 2000. № 15. С. 59-67; Сурмач О. Екуменічна діяльність УГКЦ в роки німецької окупації Галичини (1941-1943 рр.). Київська Церква. 2000. № 4. С. 72-78; Сурмач О. Соціальна опіка УГКЦ в роки німецької окупації. Історія релісій в Україні. Львів, 1999. Кн. 2. С. 161-163; Сурмач О., Малик Я. Преса про діяльність Української греко-католицької церкви в період німецької окупації (1941-1944рр.). Украӥнська періодика: історія і сучасність. Львів, 1999. С. 169-179.

64 Лисенко О. Церковне життя в Україні. 1943-1946 pр. Київ: Інститут історії України НАНУ, 1998. С. 11-46, 274-368. 
attention to the concept of V. Lypynsky, which substantiated the clear differentiation of the social functions of the state and the $\operatorname{church}^{65}$.

The monograph "Division Galicia. History "(Lviv, 2000), written by Lviv researcher A. Bolyanovsky, recreated the complex twists and turns of creation of this rifle formation in 1943, and it also unconventionally affirmed: A. Sheptytsky, supporting the formation of a division (he allocated 10 priests for its "needs "), hardly sympathized to its regional character, proposed by the German command; Metropolitan was pleased with the idea of creating a Ukrainian army based on several divisions, staffed by Ukrainians and armed by German command (pp. 68-73).

The result of years of archival searches and the recording of eyewitness accounts has become a documentary essay by Lviv scholar Petro Shkrab'yuk “The Vineyard of the Lord: A Life Story of Fr. Josyf Kladochnyi'(Lviv, 1995), which reproduces the biography of a priest and public-political figure, who constantly fulfilled the orders of Metropolitan A. Sheptytsky and the OUN, who was a chaplain of political prisoners in the 1930-50s.

Studies with generalizations have also appeared. In the monograph "Orthodoxy in the Modern History of Ukraine" (Poltava, 2001), Volodymyr Pashchenko analyzes church and religious life in Ukraine under conditions of totalitarianism, including the reaction of the Soviet authorities and the ROC to the social activity of the Greek Catholic clergy and laity after 1946.

V. Pashchenko's new work on religion is another successful case in analyzing the essence of the CPSU's (Communist Party of the Soviet Union) and Soviet state's policies on the repressed Church, in particular when deploying atheistic propaganda, implementing Soviet rituals as a means of counteracting religious traditions in the region ${ }^{66}$.

The original analytical and informational articles are published in the individual editions of the UOC (Ukrainian Orthodox Church) of the Kyiv Patriarchate. In particular, its "Shematisms" provide meaningful ecumenical materials about the past and present of church and religious life in the region. One of them contains a scientific-

\footnotetext{
${ }^{65}$ Реєнт О.П., Лисенко О.П. Українська національна ідея і християнство. Київ, 1997. С. 30-51, 65-74, 97.

${ }^{66}$ Пащенко В. Греко-католики в Україні: від 40-х років XX століття до наших днів. Полтава, 2002. С. 5-25.
} 
reference article by the Medieval-religious scholar Vasyl Kmetj about the little-known facts of the relations between the Greek Catholic and Orthodox bishops ${ }^{67}$.

Substantial editions about the Greek Catholics of Transcarpathia have also appeared. Mykhailo Boyko summarized the life and printing activities of the Transcarpathian Bishop Dionisije Njaradi, who was repressed in the spring of 1939 by the Hungarian occupation authorities $^{68}$. The life path and pastoral activity of the bishop of the Mukachevo Eparchy in the 1940s Theodore Romzha is outlined in a historical and documentary essay ${ }^{69}$. The book is also a kind of chronicle of protest by Transcarpathian Greek Catholics against the brutal violence of the communist regime towards the clergy of the eparchy, which sought to be unconnected with the ROC.

In the brochure "Galician Calvary. Liquidation of the UGCC in the Stanislav Region in 1945-1961" (Ivano-Frankivsk, 1997) archivist Ihor Andrukhiv analyzed the funds of the archive of the IvanoFrankivsk Regional Committee of the Communist Party of Ukraine (now the State Archives of Ivano-Frankivsk Oblast), which reveal the voluntarist actions of the structures of the party committee against Catholic priests and believers ${ }^{70}$. Repression against the UGCC, in particular the Greek Catholic intelligentsia, has been given considerable attention in Tamara Marusyk's monograph "Western Ukrainian Humanitarian Intelligentsia: The Realities of Life and Activity (1940-50s)" (Chernivtsi, 2001). The author has substantively analyzed the preconditions, course and consequences of the 1946 Lviv Council, in which the NKVD members took an active part.

There also appeared many historical and local studies on the history of the founding and cultural-artistic life of individual monasteries (Buchach, Krekhiv, Zhovkva, Univ, etc.) and important

\footnotetext{
${ }^{67}$ Кметь В. Львівська православна єпархія: короткий огляд історії. Шематизм Львівсько-Сокальської єпархії Украӥнської Православної Церкви Київського Патріархату. 2000 рік. Статистично-біографічний довідник. Львів, 2000. С. 8-9.

68 Бойко М. Владика Діонісій Няраді. Католицький щзорічник. Київ, 1996. C. 107-110.

${ }^{69}$ Пушкар П. Кир Теодор Ромжа. Життя і смерть єпископа. Львів, 2001.

70 Андрухів І. Галицька Голгофа. Ліквідація УГКЦ на Станіславщині в 1945 1961 рр. Івано-Франківськ, 1997. С. 33, 36-37.
} 
religious centers of Ukraine, including the "Ukrainian Lourdes" - the village of Zarvanytsya in Ternopil Region ${ }^{71}$.

The historical and religious essay by Petro Shkrab'yuk shows the national-social mission over four centuries of the Krekhiv Monastery (Lviv region), which after the Dobromyl reform of 1882-1904 opened a novitiate that began to prepare high-educated, devoted pastors, missioners for the region and for the Ukrainian communities abroad ${ }^{72}$.

Some aspects of the problem are actualized in several doctoral and $\mathrm{PhD}$ theses, defended in the specialty "religious studies". In particular, Nadia Stokolos summarized the confessional-ethnic transformations in Ukraine in the XIX - the first half of the XX century ${ }^{73}$. Yaroslav Bilas, a researcher from Lviv, summarized the socio-political views and political steps of Metropolitan A. Sheptytsky, aimed at overcoming communist and right-wing influences on society, national-political consolidation of the Western Ukrainians, reconciling the theoretical principles and practices of the nationalist movement ${ }^{74}$. The religious-philosophical work of Oksana Volynets shows the main tendencies of the development of statechurch relations in modern Ukraine, and also analyzes the phenomenon of Greek-Catholicism in the process of national and religious self-identification of Ukrainians in the conditions of the absence of their own nation-state and during the first years of its development ${ }^{75}$.

A large number of specific historical materials is included in the theses and reports of a number of international scientific conferences,

\footnotetext{
${ }^{71}$ Сагайдак М., Бубній П. Зарваниця у духовному і художньому слові, спогадах і переказах. Тернопіль, 1993. 111 с.; Андрушків Б. Зарваниця - святиня землі української. Тернопіль, 2001; Ведуть в Зарваницю стежки і дороги. Тернопіль; Теребовля, 1995; Яремич Г. Дорога до храму: Ансамбль Жовківської Василіанської церкви, монастиря, друкарні. Львів, 2000.

72 Шкраб'юк П. Крехів: Дороги земні та небесні. Львів, 2002.

73 Стоколос Н.Г. Конфесійно-етнічні трансформації в Україні (XIX - перша половина XX ст.). Автореферат дис. на здобуття наук. ступ. доктора іст. наук. Київ, 2003.

74 Білас Я.І. Митрополит Андрей Шептицький i проблеми національновизвольного руху українців. Автореферат дис. на здобуття наук. ступ. канд. іст. наук. Київ, 2003.

75 Волинець О.О. Функціонування Української греко-католицької церкви в контексті державно-церковних відносин. Автореферат дис. на здобуття наук. ступ. канд. іст. наук. Київ, 2003.
} 
published in the collections "History of Religions in Ukraine", published in Lviv since 1994 by the Institute of Religious Studies a branch of Lviv Museum of the History of Religion, by the Lviv Branch of M. Hrushevsky Institute of Ukrainian Archeography and Source Studies of the National Academy of Science of Ukraine, by the Department of Religious Studies of H. Skovoroda Institute of Philosophy of the National Academy of Sciences of Ukraine. The neglected area of research is the problem of chaplaincy, which is generally devoted to a few special publications, or individual parts of the monographs ${ }^{76}$.

Church-Religious factor of Polish-Ukrainian relations in the XIXXX centuries was considered in the studies published in 2003 by the Institute of History of Ukraine of the National Academy of Sciences of Ukraine in the collection, dedicated to the memory of P.M. Kalynychenko, "Ukraine - Poland: History and Modernity" 77 .

In the 1940-80's the problem was researched mainly in the emigrant communities. In particular, Ukrainian researchers from the Vatican, Germany, France, Australia, the USA, Canada, and Argentina paid considerable attention to state-church relations in the Carpathian region. Unfortunately, some of them have a confessional (usually Catholic) and political orientation. However, a well-known Canadian researcher of Ukrainian descent, Ivan Pavlo Khymka, studying the Greek Catholic clergy, demonstrated how at the end of the XIX century it gave way to a secular, mostly socialist, elite to a leading role in the national movement of Galicia ${ }^{78}$.

\footnotetext{
76 Литвин М. Українсько-польська війна 1918-1919 рр. Львів, 1998. С. 188-199; Кияк Р. Капелянська служба у Збройних силах України. Нова зоря. 1996. Ч. 21.

77 Реєнт О. Українсько-польські відносини в XIX - на початку XX ст. Історіографічні дослідження в Украӥні / Голова редкол. В. Смолій; відп. ред. Ю. Пінчук. Вип. 13. У 2-х ч.; Україна - Польща: історія і сучасність. Збірник наук, праць і спогадів пам'яті П.М. Калиниченка (1923-1983). Ч. 1. Київ, 2003. С. 90-97; Марчук В. Церковно-релігійне життя в Західноукраїнській Народній республіці (1918-1919 рр.). Історіографічні дослідження в Україні. С. 215-220; Заброварний Б. Депортації українського населення із Закарпаття в 19441947 роках. Історіографічні дослідження в Украӥні. С. 359-374.

${ }^{78}$ Himka J.-P. Priests and Peasants: The Greek Catholic Pastor and the Ukrainian National Movement in Austria, 1867-1900.Canadian Slavonic Papers. 1979. N 21 (1). P. 1-14; Himka J.-P. The Greek Catholic Church and Nation-Building in Galicia, 1772-1918. Harvard Ukrainian Studies. 1984. N 8 (3-4). P. 426-452; Himka J.-P. Galician Villagers and the Ukrainian National Movement in the Nineteenth
} 
A rich source material is represented in the post-war publications "Basil the Great"(Rome), which were written with the involvement of the documents of the Vatican Archives and the Ukrainian Catholic University named after Pope St. Clement (Rome) ${ }^{79}$.

Diasporic scientist Stakhiy Stebletskyi researched the repression of Russian imperial power against the Ukrainian and Belarusian Catholic churches in the XVIII - XX centuries ${ }^{80}$. In 1985 Ukrainian emigration publishing house "Smoloskyp" named after V. Stefanyk (Toronto; Baltimore) published a documentary compilation "Martyrology of the Ukrainian Church", which compiled various documents, materials and memoirs that reproduce the list of Greek Catholic bishops and priests, who were imprisoned and tortured in the Soviet concentration camps, as well as activities of the religious communities in the underground ${ }^{81}$.

State-church relations in the region have always been the focus of Polish researchers, whose studies have contained a great deal of fact, but, as a rule, have been confessionally engaged. At the same time they are the basic studies for researching the policy of Latinization of the border, first of all the Chelm Land, Podlasie, Lemkivshchyna, conducting the Jesuit reform of the Basilian order at the end of the XIX - beginning of the XX centuries ${ }^{82}$.

Century. Houdmills, 1988; Himka J.-P. Religion and Nationality in Western Ukraine: The Greek Catholic Church and the Ruthenian National Movement in Galicia, 18671900. Montreal-Kingston (Ontario), 1999.

79 Патрило І. Джерела і бібліографія історії Української Церкви. В 3-х томах. Рим, 1975, 1988, 1992.

80 Стеблецький С. Переслідування Української і Білоруської католицької церкви російськими царями. Мюнхен: Українське католицьке видавництво, 1954. С. 59-60, 78

${ }^{81}$ Мартирологія Української Церкви / Упор. О. Зінкевич, Т. Лончина. Торонто; Балтимор, 1985. 839 с.

82 LubieńskiHenryk. Kościół Grecko-Katolickiwwojewództwachpołudniowowschodnich. Warszawa, 1935. 213 s.; UmińskijJózef. Historiografm Kościelna (stanbadań i wazniejsze postulaty).Kwartalnikhistoryczny. Lwów, 1937. R. LI. S. 329-332; Jurkiewicz Jarosław. Watykana Polskawokresiemiedzywojennym 1918-1939. Warszawa, 1958. 313 s.; SliwaW. Kościół grecko-katolickiwPolscewlatach 1918-1939. Kościól wIIRzeczypospolitej/ Red. Z. Zilinski, S. Wilka. Lublin, 1981. S. 149-164; Prus Edward. Władyka świętojurski. Warszawa, 1985. 286 s.; Krasowski Krzysztof. Episkopat KatolickiwIIRzeczypospolitej. Warszawa; Poznań. 288 s.; Soczyński Roman. 400-lecieUniiBreskiej. 1596-1996. Warszawa, 1996. 232 s.; 
Serious studies include Richard Tozhetsky's publications on Polish-Ukrainian relations in the 1920-40's. In particular, the Warsaw historian objectively showed the family roots of Andrey Sheptytsky, his political intelligence, organizational abilities in building a metropolis, ecclesiastical and diplomatic actions in Rome, Paris, Belgium, USA, Brazil, Argentina in support of "independence of his people", as well as against the Entente's intervention in the affairs of the Western Ukrainian People's Republic and ... non-accession of Eastern Galicia to Poland" ${ }^{\prime 83}$.

Stanislav Stempnya's church and religious studies, published in a five-volume editorial entitled "Poland - Ukraine. 1000 Years of Neighborhood" (Przemysl, 1990-2000), are noteworthy. In particular, the second volume is devoted to the history of Eastern Christianity at the Galician ethnic and cultural border ${ }^{84}$, the third - to the history of the Przemysl Greek Catholic Eparchy (authors - Tadeusz Sliva, Tomasz Stryek, Anna Krochmal, Dariusz Ivanenko, etc. $)^{85}$, and the fifth - to the place and role of the Greek Catholic Church in the Ecumenical Church ${ }^{86}$.

Summarizing the historiographic review, we should note that the sacrificial chronicle of the UGCC at the end of the XIX XX centuries did not become the subject of a comprehensive scientific study. Theologians, religious scholars, historians and educators have covered some of its sections in special publications.

The whole set of identified sources, which are necessary for the study of the social and creative activity of the church, its priests and believers, we propose to classify by their origins into the following groups: program documents of councils and synods, official documents of the UGCC leadership, pastoral letters of metropolitans; the epistolary of clergymen with official institutions, public

RzemieniukF. UniciPolscy. 1596-1946. Siedlce, 1998. 286 s.

83 TorzeckiR. Metropolita Andrej Szeptycki. Znak. 1988. N 9. S. 55-63; Тожецький Р. Митрополит Андрей Шептицький. Ковчег. Ч. 1. Львів, 1993. C. 101-112.

${ }^{84}$ Polska - Ukraina. 1000 lat sąsiedztwa. T. 2: Studia z dziejow chrześciaństwa na pograniczu kultumym i etnicznym / Pod red. S. Stępnia. Przemyśl, 1994. 430 s.

${ }^{85}$ Polska - Ukraina. 1000 lat sąsiedztwa. T. 3: Studia z dziejow chrześciaństwa na pograniczu kultumym i etnicznym / Pod red. S. Stępnia. Przemyśl, 1996. 336 s.

Polska-Ukraina. 1000 lat sąsiedztwa. T. 5: Miejsce i rola Kościoła Greckokatolickiego w Kościełe powszechnym. Przemysl, 2000. 568 s. 
organizations, societies and parties, individuals; documents of central and local authorities and administrations of Austria-Hungary, Russia, Poland, Germany (General Governorate), USSR-UkrSSR (legislative, executive and judicial bodies, police structures, communist organizations); documents of the authorities and administration of the Western Ukrainian People's Republic, the command of the Galician army, the Reverend Service; documents of the political parties, nongovernmental organizations and associations; documents of the authorities and administration of independent Ukraine (after 1991); works of Ukrainian ecclesiastical, public-political and state figures; documents of the Apostolic Capital, international organizations and conferences; memories of direct participants and witnesses of events; periodicals and non-periodicals; materials of personal origin; photo and video documents, works of art.

The most unpublished documents, which are directly related to the problem, were found in the funds of the Central State Historical Archives of Ukraine in Lviv: 358 (Sheptytsky Andrey-Olexandr, Earl, Metropolitan of the Greek Catholic Church), 408 (Greek Catholic Metropolitan Ordinariate, Lviv), 201 (Greek Catholic Metropolitan Consistory, Lviv), 409 (Central Administration of the Greek Catholic Metropolitanate Estates, Lviv), 684 (Protohegumenate of the Order of St. Basil the Great), 508 (Youth Society of Virgin Mary, Lviv) etc. Unfortunately, part of these documentary collections is now in the archives and libraries of eastern Poland, in particular in the National Library of Poland (Shevchenko Scientific Society archive).

Documents on Church-Religious Life in Galicia, Socio-Political Activity of Metropolitan A. Sheptytsky and separate Bishops in the 1920-40's are also contained in the funds of the State Archives of the Lviv oblast: 1 (Lviv Voivodeship Administration), 110 (Lviv City Starostvo), 121 (Lviv Voivodeship Department of the State Police), etc.; State Archives of Ivano-Frankivsk Oblast: 2 (Stanislav Voivodeship Department, Stanislav (1921-1939), 68 (Department of State Police in Stanislav District, Stanislav (1921-1939), 69 (Stanislav County State Police Office (1921-1939), 226 (Prosecutor's Office of the District Court, Stanislav (1922-1939) and others.

The repressive actions of totalitarian power against the Greek Catholic Church in the 1940's are disclosed in the materials of the Central State Archives of Higher Authorities and Administration of 
Ukraine, the Central State Archives of Public Associations of Ukraine. The plans of the leaders of the Central Committee of CPSU and the Kremlin overseers to neutralize the "Uniate Nationalists" are revealed in the secret materials of the State Archives of the Russian Federation, the Russian Center for the Preservation and Study of Documents of Recent History (first of all, Fund 17 - Central Committee of CPSU).

In the Archives of the Security Service of Ukraine in IvanoFrankivsk oblast there are criminal cases against the repressed figures of the Greek Catholic Church, in particular a case of Bishop Hryhoriy Khomyshyn (1867-1945), which was started in 1945. Similar cases of repressed priests are in the Archive of Security Service of Ukraine in the Lviv oblast and the Archive of Security Service of Ukraine in the Ternopil oblast.

Specific information on the national and cultural life of the Galician and Bukovynian Ukrainians, publishing on religious thematic and church art of that time is contained in the departments of manuscripts, rare books, art and Ukrainian studies of the Stefanyk National Science Library in Lviv, also at the Scientific Library of Ivan Franko National University of Lviv, state, public and church libraries of Poland, Russia, Canada, Vatican ${ }^{87}$.

Important sources of information on church-religious and personal life, national upbringing, mentality of Galicia people, theological studies were religious periodicals and non-periodicals: "Missionary" (1897-1944), "Small Missionary" (1903-1914, 1939), "Nyva" (19041914, 1916-1939), "Osnova" (1906-1914), "Our Friend" (19221939), "Progress" (1921-1927), "The Knighthood of the Blessed Virgin" (1935-1939), "Catholic Action" (1934-1939), "Dzvony" (1931-1939), “Good Shepherd” (1930-1939), "Sivach” (1936-1939), "Christ is our Power" (1934-1939), "Nova Zorya" (1926-1939), "Notes of the Order of Saint Basil the Great" (1924-1939, 1942), "Theology" (1923-1942) and others. Most of them have been published in Lviv, some in Zhovkva, and "Nova Zorya" in Stanislaviv.

Ecclesiastical authorities have traditionally published official information: "Lviv Archdiocesan Records" (1889-1944), "Przemysl

${ }^{87}$ Нариси історії архівної справи в Україні / За заг. ред. І. Матяш, К. Климової. Київ, 2002. С. 537-556. 
Eparchy Records" (1889-1918), "Bulletin of the Przemysl Eparchy" (1889-1918), "Bulletin of the Stanislav Eparchy" (1886-1939) ${ }^{88}$. The secular press, published in Lviv, Stanislaviv, Kolomyia, Ternopil, Zhovkva and other cities, is also widely used.

A considerable number of sources on the investigated subjects was published in the collections of documents and materials prepared by the archeographers of the Vasyl Stefanyk Precarpathian National University ${ }^{89}$, I. Krypiakevych Institute of Ukrainian Studies of the National Academy of Sciences of Ukraine ${ }^{90}$, T. Shevchenko Kyiv National University ${ }^{91}$, Lviv Theological Academy ${ }^{92}$.

Some documentary collections, published in the UkrSSR, which contained the materials on state-church relations in the region in the XIX - XX centuries, have not lost their informative value ${ }^{93}$.

Important sources of the study include public speeches and studies by the prominent church figures - A. Sheptytsky, H. Khomyshyn, Y. Dzerovych, J. Slipyj, H. Kostelnyk, L. Lyubachivsky, L. Husar, S. Mudryi, and others, who largely determined the vectors of the

88 Кревецький I. Українська католицька преса. Нова зоря. 1928. Ч. 101; Канчалаба О. Релігійно-церковна періодика XIX - першої половини XX ст. у фондах ЛНБ ім. В. Стефаника НАН України. Українська періодика: історія $i$ сучасність. Вип. 6. Львів, 2000. С. 189-193; Крив'як Б. Видавничопросвітницька діяльність Василіянського Чину в Україні. Київська церква. 1999. Ч. 6. С. 36-37; Мартинюк М. Українські періодичні видання Західної України, країн Центральної та Західної Свропи (1914-1939рр.): Матеріали бібліографії. Львів, 1998.

89 Західно-Українська Народна Республіка 1918-1923. Док. і мат. У 5-ти томах / Відп. ред. О. Карпенко. Т. 1-2. Івано-Франківськ, 2001

90 Культурне життя в Україні: західні землі. Т. 1-3. Львів, 1995, 1998, 2006; Літопис нескореної України. Т. 1-2. Львів, 1993, 1995; Депортації: Західні землі України кінця 30-х - початку 50-х рр. Документи, матеріали, спогади/ Відп. ред. Ю. Сливка. Т. 1-3. Львів, 1996-2003.

91 Сергійчук В. Нескорена церква: Подвижництво греко-католиків України в боротьбі за віру і державу. Київ, 2001. 496 с.

92 Митрополит Андрей Шептицький: життя і діяльність. Документи і матеріали 1899-1944 / Упоряд. О. Гайова, А. Кравчук. Т. 1. Церква і церковна єдність; Т. 2. Кн. 1 Церква і суспільне питання. Пастирське вчення та діяльність. Т. 2. Кн. 2. Церква і суспільне питання. Листування. Львів, 1995-1998. Т. 1. 521 с. Т. 2, кн. 1.572 с. Т. 2., кн. 2.571 с.

93 Діяння Собору УГКЦ 8-10 березня 1946 р. Львів, 1946. 167 с.; Правда про унію. Док. і мат. Вид. друге, доп. Львів, 1968. 422 с.; Документи свідчать. Вид. друге, доп. / Упор. А. Гайдаш. Ужгород, 1985. 160 с. 
complex transformations that the Greek Catholic Church has undergone over the past century ${ }^{94}$.

The used religious-memoir literature (M. Vavryk, I. Nazarko, I. Lebedovych, M. Tsehelsky, M. Chubaty, etc.) is characterized by various facts, and mainly by personal vision of the events in socialpolitical, church-religious and cultural-artistic life in Ukraine.

Thus, the available historiography and the base of sources make it possible to reveal the nature, social mechanisms and consequences of ethno-confessional transformations of church-religious life in the Western Ukrainian lands under the authority of foreign states, which sought to deprive the Galician Ukrainians of spiritual leadership and the national government - of institutions. The tendencies that are taking place in the church-religious relations and national-cultural life of Greek Catholics of independent Ukraine are also revealed. The search for truth is accomplished by analyzing the whole set of documented facts.

94 Митрополит Андрей Шептицький: Життя і діяльність. Т. 1-2. Львів, 19951999; Костельник Г. Нова доба нашої Церкви. Львів, 1926; Костельник Г. Вибрані твори. Київ, 1987; Костельник Г. Ultra posse. Вибрані твори / упоряд. та передм. О. Гірняк. Ужгород: Гражда, 2008; Гузар Л. У пошуках гармонії. Історичний контекст укладення Берестеської унії і перше поунійне покоління : матеріали Перших «Берестейських читань». Львів, Івано-Франківськ, Київ, 16 жовтня 1994 р. / ред. Б. Гудзяк. Львів: Інститут Історії церкви Львівської Богословської Академії, 1995. С. 1-6. 
DOI https://doi.org/10.36059/978-966-397-213-8/32-66

\section{PART 2. \\ THE STRUGGLE FOR THE NATIONAL IDEA PRESERVATION AS AN ELEMENT OF THE GREEK-CATHOLIC CHURCH ACTIVITY}

It is a well-known fact that Ukrainian nation builds its national life on the geographical and cultural crossroads of the East and the West. This very proximity of both Western and Eastern civilizations, Christianity and Islam, Catholicism and Orthodox Christianity is to blame for the intricacies of the church and religion processes in Ukraine. Therefore, the people's national and cultural identity, as well as their religious traditions, were formed under the influence of both West and East. Still, as a famous Lviv dissident Ivan Gel' puts it, it is Europe that is responsible for the biggest impact on the ethnical culture of Ukraine as the latter has always been an integral part of the former ${ }^{95}$.

The long history of the Ukrainian Church witnessed several crucial events. They are the baptizing of the year 988, the Union of Brest in XVI century, undercover church activity and the revival of the Greek Catholic church in the second half of the XX century.

The event with the greatest importance was the baptizing of the Kyivan Rus', as the state managed to become fully Christian in the period of one-two generations lifetime. Still, there was strong evidence of Christianity present on the territory of the modern Ukraine long before baptizing, it is documented in the historical manuscripts, and it might have got to the country through the modern Transcarpathian region, which bordered on the Holy Roman Empire $^{96}$. Various historical sources testify to the spread of Christianity in the south of present-day Ukraine as far as the II century. In the "Zhytije sviatyh" («Lives of the Saints») there are repeated mentions about the Rus' Christians who lived in the VIII -

\footnotetext{
95 Гель І. Духовність України і спільний європейський дім. Украӥна. Наука i культура. Вип. 26-27. Київ: Знання, 1993. С. 132.

96 Пап Степан. Історія Закарпаття. Т. 1. Івано-Франківськ, 2001. С. 234-236.
} 
IX centuries; and in 839 there was the first mention of the bishops in Przemysl ${ }^{97}$. The existence of Christians among the Rus' people is also confirmed by the contract of Prince Igor with the Greeks in 944. His wife Olga was a Christian, who adopted Christianity during her official visit to Constantinople in 946, which was under the rule of the Emperor Constantine VII Porphyrogennetos ${ }^{98}$. Afterwards she invited German bishops and priests to come and preach in the Kyivan Rus'. According to the legend, Christian disciple Andrew the Apostle once visited the Kyiv Mountains and predicted the appearance of a large city with numerous temples ${ }^{99}$.

Having baptized Rus'-Ukraine in 988, Volodymyr the Great (Vladimir the Great), the Grand Duke of Kyiv, officially recognized Christianity as a state religion. The historian of the Ukrainian church, bishop Andrii Sapeliak states that with this act Volodymyr the Great created "the lasting Christian foundation for the unity of the Kyiv state, which exists in Eastern Europe, alongside the Roman-German Empire in the West and Byzantine in the South. The direct relations of Kyivan Rus' with Rome, which was the center of Christianity, also served as a guarantee of its independence, in a way"100.

Two prominent Slavic disciples, Saints Cyril and Methodius, made their important contribution to laying foundation of the Ukrainian Church; long before the baptism of the state took place both of them popularized Christianity on the western boundaries of the Kyivan Rus'. Their work was highly appreciated and supported by the Pope. The peculiarity of their missionary and scholarly work was that "the activity of the Saint Brothers Cyril and Methodius built a bridge between the West and Eastern Christianity" ${ }^{101}$. Thus, the main principle of the formation of the Cyril and Methodius culture, which is basically a combination of Byzantine and Roman

\footnotetext{
${ }^{97}$ Polska-Ukraina. 1000 lat sasiadstwa. T. 1. Przemyśl, 1990. S. 39-133; T. 3. 1996. S. 21-36.

98 Історія України / Заг. ред. В. Смолія. 3-є вид. Київ, 2002. С. 32-33.

99 Андрієнко О. 3 історії Української церкви. Київська старовина. 1992. № 1. C. 136 .

100 Сапеляк А. Київська церква на слов'янському Сході. Буенос-Айрес; Львів, 1999. С. 7.

${ }^{101}$ Полонська-Василенко Н. Історія України. Т. 1. Київ: Либідь, 1992. С. 94.
} 
ecclesiastical elements ${ }^{102}$, influenced Ukrainian Christianity from its onset. At the same time, the young Ukrainian Church clearly defined its identity as a part of the Ecumenical Church, it introduced the Slavic language into the church ceremonies, consequently, Slavic obtained the same level of importance as Greek and Latin, which clearly prevailed in the Christian world.

A well-known historian M. Chubaty, who dealt with the history of church, introduced the scientific concept of Ukrainian Christianity as a cross between Eastern Christianity and Western Christianity, formed on the basis of the pre-Christian culture of the Rus-Ukraine of the Dnieper region, he emphasized that as early as the end of the IX century it led to the creation of a clearly defined spiritual image of the Ukrainian nation with its individuality ${ }^{103}$. Strong political and ecclesiastical ties with Rome also contributed a lot to this process. The center of the Universal Church was visited by five embassies during the reign of Volodymyr the Great, later on this tradition found its continuation with his successors, especially during the rule of Yaroslav the Wise, who strengthened relations with the West by the means of dynastic marriages. The existing cult of St. Pope Clement, whose relics were transported to Kyiv, serves the clear evidence of the natural connection between the early Kyiv Christianity and Rome, which was the citadel of the European civilization back then.

After the collapse of the Roman Empire and the heyday of the Byzantine Empire, in 1054 there happened a split of the United Apostolic Church into Western Roman (Catholic) and Eastern Byzantine (Orthodox) ones. The hierarchs of Kyiv did not support the split because they had strained relations with Byzantium. Further actions of the Kyivan Rus' rulers proved they wanted to continue mutually beneficial relations with Western countries, those include an appeal of Grand Duke Iziaslav to Pope Gregory VII in 1073, keeping in touch with Pope Clement III on the part of the Kyiv Metropolitan Archbishop, developing relations with rulers of Germany, Poland, Hungary, England with the help of marriage ties, even though these

\footnotetext{
102 Паславський І. Берестейська Унія і українська християнська традиція. Львів: Місіонер, 1997. С. 8-9.

103 Чубатий М. Історія християнства на Руси-Україні. Т. 1. Рим; Нью-Йорк, 1965. C. 108.
} 
countries remained under the jurisdiction of Rome. The Ukrainian church of the period of Kyivan Rus' developed rather successfully, there were built grand temples in big cities, at the beginning of the XI century there existed 400 churches and 17 monasteries, with lots of them situated in Kyiv. It's worth noting that 600 churches burnt down in Kyiv in 1124 because of a massive fire, as it is written in the manuscript ${ }^{104}$.

Since the ancient period, churches were perceived as a centre of public and cultural as well as educational life. They had schools opened on their basis, and many monasteries were places where books were created and preserved. In the XIII century the Kyiv Metropolis (founded in 1037) ruled over 21 eparchies. After the Universal Church split into two, the Ukrainian Church tried to maintain neutrality - "it tried to be an equilibrium factor, the third party, a buffer between East and West, both of which tried hard to influence the Ukrainian position, it being the center of their regional interest"105. Byzantium side was particularly aggressive. It made attempts to limit the political, cultural, and ecclesiastical ties of Rus' with the West, and played its part in intrigues and strifes between the princes in order to weaken the Kyiv state and its church. Therefore Dmytro Stepovyk called it "Byzantine church imperialism"

After Kyivan Rus'-Ukraine lost its might, the Kingdom (Principality) of Galicia-Volhynia inherited its status and became the centre of ethno-political life, since its appearance on the geopolitical map of Europe in $1199^{107}$. The princes of Halych did their best to create the Metropolis of Halych and succeeded in 1302. Centered in Halych, it maintained close relations with Rome, which might be proved by the fact that Pope Innocent IV granted the royal title to Daniel of Galicia in 1253. This fact was of such a great importance

\footnotetext{
104 Полонська-Василенко Н. Історія України. Т. 1. Київ: Либідь, 1992. С. 236.

105 Сімкайло М., о. Берестейський собор і його значення. Берестейська Унія (1596-1996). Статті і матеріали. Львів: Логос, 1990. С. 75.

${ }^{106}$ Степовик Д. Множинність і єдність церкви. Київська Старовина. 1993. № 5. C. 10 .

107 Київська Русь: культура, традиції / Відп. ред. Я. Ісаєвич. Київ, 1982; Крип'якевич I. Галицько-Волинське князівство. Львів, 1999; Ісаєвич Я. Галицько-Волинська держава. Львів, 1999; Александрович В. Мистецтво Галицько-Волинської держави. Львів, 1999.
} 
that Mykhailo Hrushevsky stated "it was under Daniel's reign... that we got proclaimed a union with Rome" ${ }^{\text {"108 }}$.

For some time, Rome expressed full support to the Ukrainian Church and the state-building activities of the princes from GaliciaVolhynia. However, after the state had fallen victim to Polish expansion and annexation, Rome changed its church policy towards the Ukrainian lands dramatically and fully assisted to the Polish Catholicism promotion. At the beginning of the XV century, in 1414 despite the scarcity of Catholics living in the region there was created the Latin Metropolis in Lviv. It had to serve a single political purpose: to destroy the spiritual stronghold of the enslaved people ${ }^{109}$.

One could witness a serious decline of spirituality on the territory of Ukraine during the XIV - XVI centuries. After the Union of Lublin was signed in 1569, the Polish-Lithuanian Commonwealth got control over the Right Bank Ukraine. Still, it was Galicia region, which suffered the most under the Polish rule: its society was divided into higher and lower strata: the former one being flourishing Polish with its culture, language and Catholicism, while the latter one remained Ukrainian, where people still practiced Orthodox faith and used their national language. Naturally, there appeared certain contradictions between these strata, they were exacerbated by national and religious chauvinism, which revealed itself to the full scale during the Ukrainian Revolution of the XVII century, which happened shortly after ${ }^{110}$.

Thanks to the Jesuits influence, the Polish Catholic Church grew stronger and stronger. Their extensive missionary work was carried out by the orders of Dominicans, Bernardines, Franciscans in the XIII - XV centuries. They used to found Polish schools and spread Catholicism by all means available. The state policy of Poland was aimed at destruction of the Ukrainian Church, which remained the spiritual core of the Ukrainian nation.

\footnotetext{
108 Грушевський М. Історія України-Руси. Т. V. Київ, 1994. С. 508; Т. III. Київ, 1993. С. 69-73.

109 Панас Кость, о. Історія Української церкви. Львів, 1992. С. 44; Львів: історичні нариси. Львів, 1996. С. 521.

${ }^{110}$ Полонська-Василенко Н. Історія України. Т. 1. Київ: Либідь, 1992. С. 374.
} 
Another threat to the Ukrainian Church was posed by Moscow. After Constantinople had fallen in 1453, Moscow declared itself the heir to Byzantium and the "Third Rome". This became the state ideology under the reign of Ivan the Terrible, when Moscow was recognized as the capital, and after the government got united with the church. Under the pretenses of guardianship over the Orthodox believers and making an attempt to annex the Ukrainian lands, Moscow proclaimed Jon the Patriarch of Moscow and "All Great Russia", including Ukraine ${ }^{111}$.

Under these circumstances, the Ukrainian Church leaders concluded that the only way to preserve the church and the identity of the Ukrainian nation was to sign a union with the Roman Church and recognize the Holy See. In its time the First Council of Lyon in 1245, where some of the Ukrainian Church representatives were present, also served as an important milestone in the unification process. Archbishop Petro Akerovych informed the Apostolic Capital about the Tatar-Mongol invasion. The Second Council of Lyon declared the union between the Eastern and Western churches. This union was caused more by political than religious motives, therefore, it was fragile and non-lasting. Still, the leaders of the Kyiv Metropolis clearly understood that the union with Rome would be beneficial for the state, so they repeatedly tried to achieve it. The proof of this might be seen in the fact of participation of Metropolitan bishop Hryhoriy in defending the interests of the state, consistently argued for union with Rome. This was evidenced by the participation of Metropolitan Gregory in the Council of Constance in 1418, which was the first pan-European forum of the church and secular elite. In his speech, the Metropolitan bishop stated that the Ukrainian church was ready to recover the spiritual unity with the Holy See.

In 1439 Pope Eugene IV convened the Council of Florence in order to introduce the Union and the Ukrainian Church delegation (100 people), headed by Metropolitan bishop Isidore of Kyiv, played

111 Нагаєвський I., о. Католицька церква в минулому і сучасному України. Філадельфія, 1950. С. 27-28. 
a rather important role in $i^{112}$. The actions of Isidore contributed to the important decisions of the council, primarily it concerned the recognition of the Pope as the head of the Universal Church and the unification of the Western and Eastern churches. The union was signed by 115 bishops of the Latin Church.

Soon afterwards the Kyiv Metropolis returned from Moscow to its homeland, which strengthened the Kyiv-Halych Metropolis. According to the decision of the Union, the Eastern churches received the same status as Latin ones, and this fact significantly restricted processes of catholicization and polonization of Ukrainians. In 1458 Pope Pius IV appointed Gregory II of Kyiv the Metropolitan bishop, and he was in charge of the Ukrainian and Belorussian territories ${ }^{113}$.

The fate of the Ukrainian Church was heavily affected by the fall of Byzantine under the Turkish attack, and consequently the fall of the Patriarchal Center of Orthodoxy of Tsarhorod (Constantinople). Under the Turkish pressure, the Ecumenical Patriarch of Constantinople renounced his union and terminated relations with Rome. Both Lithuania and Poland also caused great damage to the national and religious life of Ukraine. Their Latin-Catholic circles refused to accept the Union, because it did not fit into the policy of spreading Catholicism among Ukrainians and Belarusians. They expected that the Union would become the instrument of Latinization of the Ukrainian Church. Their motto was "Whoever is not Latin Catholic is not a Christian". The Orthodox church was also constantly attacked by Protestants, not just by Latin Catholics. Some Ukrainian magnates, especially Konstantyn Ostrogski, who owned vast territories of Volyn and Galicia, came to the defense of the Ukrainian Church $^{114}$.

From the very start of their existence, religious fraternities contributed a lot to the preservation and development of the

\footnotetext{
112 Чубатий М. Історія християнства на Руси-Україні. Т. 2. Рим; Нью-Йорк, 1965. С. 164; Пашук А. Українська церква і незалежність України. Львів, 2003. C. 46-57.

113 Сапеляк А. Київська церква на слов'янському Сході. Буенос-Айрес; Львів, 1999. C. 15.

114 Сліпий Йосиф, митрополит. Історія Вселенської церкви на Україні. T. IV. Ч. 2. Рим, 1994. С. 29; Грушевський М. Історія України Руси. Т. V. С. 590-618.
} 
Ukrainian Church. They provided financial assistance to citizens, organized cultural and educational activities, and defended the church from the Latin-Catholic influence ${ }^{115}$. However, in the second half of the XVI century, fraternities increasingly extended their rights and started to interfere in the church activity: they wanted to have control of internal affairs, to have a say about the competence of bishops, to elect priests and bishops. They were seriously supported by the Patriarch Jeremias II of Constantinople who removed them from jurisdiction of bishops and subordinated them to himself in 1586, by means of granting the right of stauropegion. As a result, the church began to decline and the relations between the fraternities and the church hierarchy, which sought to get rid of dependence on secular structures, escalated. The contradiction between the Ukrainian Church and the Patriarch of Constantinople reached a threatening level. The hierarchs of the Orthodox Church fought against fraternities' policies. Bishop Hipatius Poceij, who became a Metropolitan bishop of Kyiv later as well as one of the creators of the Union, considered fraternities to be a pillar of the reformation movement, and he was right. He also believed that secular interference into the internal affairs of the church was heretical.

Comparing to the beneficial position of the Latin Catholic Church, the Ukrainian one was in a humiliating position, as it was secondary one and tried to develop without the state support. The decline of religious education had a negative impact on the intellectual and cultural level of the priesthood. The same result was provided by the practice of secular officials to interfere into the religious personnel problems. The Ecumenical Patriarchate of Constantinople did not really care about the state of affairs of the Ukrainian Church. Its interest was limited to the amount of money it received.

At the same time, the Moscow Church was gradually moving away from it, especially after the formation of its own patriarchate in 1589. It intensified its actions in cooperation with the current tsar in the aspect of expansion and strengthening of its influence on the Ukrainian Church. Still the Kyiv Metropolis tried to remain

115 Ісаєвич Я. Братства та їх роль в розвитку української культури XVI XVIII ст. Київ, 1966; його ж. Львівське успенське братство, його школа i друкарня. Львів: історичні нариси. Львів, 1996. С. 82-89. 
independent, as it was westward-leaning and considered cooperation with Rome its priority, with Rome being the center of the Universal Church. The Kyiv Metropolis refused to accept the Moscow Church's policy of state domination, autocephalous isolation, and rejected Constantinople's calls ${ }^{116}$.

Under these circumstances, the hierarchs of the Ukrainian Church, who had been in search of a radical solution to the urgent problems of the church for a long time, came to the conclusion about the possibility of a union with Rome. The main aim of the union was to get the Ukrainian church out of the deep crisis, and therefore save it as well as the identity of the Ukrainian nation. The intentions of the Ukrainian hierarchs were in perfect tune with the course, adopted during the Council of Florentine and met its conditions ${ }^{117}$. The fact that Hipatius Pociej joined the ranks of the Ukrainian bishops in 1593 was also an important contribution to the process of unification, as this person was a prominent church figure, writer and theologian, and later on his activity was closely connected with the Union of Brest in $1596^{118}$. Polish King Sigismund III was among the long-standing supporters of the union, he was clearly supported by the whole hierarchy of the Latin Church. The union initiative was fully approved not only by the Ukrainian bishops, but also by Pope Clement VIII, while he was informed about the state of the Ukrainian church and consequently was interested in its restoration, being an advocate of the ecumenical process.

At the same time, the union had many opponents. The Constantinople patriarch and other patriarchs of the East were the first to disapprove of it. After a meeting in Iasi in 1595, they sent a pastoral letter to the Ukrainian clergy of four believers in which they strongly disapproved of the intentions of Metropolitan bishop M. Rogoza and other bishops to unite with the Holy See and accused them of betrayal of the Orthodox Church. On the opposite side, there

116 Нагаєвський I., о. Католицька церква в минулому і сучасному України. Філадельфія, 1950. С. 41.

117 Паславський І. Берестейська Унія і українська християнська традиція. Львів: Місіонер, 1997. С. 37.

118 Паславський I. Іпатій Потій. До 450-річчя від дня народження. Ратуша. 1991. 28 вересня. 
were Catholic circles of Poland, who considered the union from a political-state point of view, and consequently they did not want to equalize the Ukrainian Church with Latin, and thus give Ukrainian the same rights Poles had ${ }^{119}$. Subsequently, a certain number of Ukrainian representatives could see through it and, as a result, ambitious K. Ostrogsky became an active opponent of the union, moreover he managed to persuade several bishops to join his side, including Bishop Gideon Balaban of Lviv, Mykhail Kopystensk of Przemysl, some influential representatives of nobility and clergymen who did not support the concept of a local church union ${ }^{120}$.

During the Synod of Brest in 1595, the initiators and creators of the union worked out and approved 33 articles on the conditions of the Ukrainian Church entry into the Holy See. The main conditions were as follows: the church retained the Eastern rite, its customs, the liturgical language; it preserved the right to elect bishops from among their candidates and their further ordination by a metropolitan bishop; it obtained the same equality as the Latin church in terms of taxation and privileges; Ukrainian bishops were to be granted seats in the Senate; Ukrainian nobility and city dwellers should have received equal rights with the followers of the Latin rite and should have been equally allowed to run for positions in city and state governments; it would be forbidden to force Orthodox faith followers into Catholicism, etc ${ }^{121}$.

On September 28, 1595, the Ukrainian delegation (23 people) left for Rome and arrived to the residence of Pope Clement VII on November 15, he met them two days later, and, having heard their statement on church unity, expressed the consent of the Holy See. On December 23, a solemn act of reunification or restoration of the union of the Ukrainian Church with the Ecumenical Church took place in the presence of 33 cardinals, the diplomatic corps of Europe,

119 Сапеляк А. Київська церква на слов'янському Сході. Буенос-Айрес; Львів, 1999. C. 28.

${ }^{120}$ Кметь В. Львівська єпархія: короткий огляд історії. Шематизм ЛьвівськоСокальської Української Православної церкви Київького Патріархату. 2000 рік. Львів, 2000. С. 17-19.

121 Завірач Василь, о. Флорентійський Вселенський Собор і Берестейська унія. Берестейська Унія (1596-1996). С. 65-66. 
and other representatives of the hierarchy. According to the Papal Bull of Pope Clement VII from February 23, 1596 the Ukrainian Church was defined as a local autocephaly in the union with Rome, and the document itself became the main canonical document of the Union of Brest.

Even before the Ukrainian ambassadors had left for Rome, the Pope had addressed the Polish King and the Senate, in his letters he had asked them to support the Uniate Church and grant Senate seats to its bishops, while the hierarchs of the Latin Church in Poland and influential politicians were to guarantee the exercise of equal rights for both churches ${ }^{122}$. Metropolitan bishop M. Rogoza received a letter, which instructed him to convene a meeting of Ukrainian bishops for the final settlement of the unification process, which had received full support in Rome ${ }^{123}$. The ratification of the Roman Act on the reunification of the Ukrainian Church with the Ecumenical church took place at the council held in the St. Nicholas Church in Brest (October 6-8, 1596), there were present Ukrainian as well as Polish bishops, papal delegates, royal ambassadors and priests ${ }^{124}$.

Simultaneously with the Union of Brest, there was held a different council headed by Prince K. Ostrogsky. He convened a meeting for the hierarchs of the Orthodox Church, including bishops from Lviv and Przemysl, nobility representatives and priests (about 200 people). Despite the king's objections and defying canonical dogmas, he declared that meeting to be a synod, and then the decision against the Union was made ${ }^{125}$. Still, actions of K. Ostrogsky could not stand in the way of ratification of the union and that's what happened during the Council of Brest with the support of majority of church followers and priests. Anyway, the determined struggle of K.Ostrogsky and his adherents hindered the development of the Ukrainian church, it led to appearance of the two opposite camps - the one of the supporters of the union and its opponents.

${ }^{122}$ Грушевський М. Історія України-Руси. Т. V. Київ, 1994. С. 596-603.

123 Сапеляк А. Київська церква на слов'янському Сході. Буенос-Айрес; Львів, 1999. C. 40.

${ }^{124}$ Грушевський М. Історія України -Руси. Т. V. Київ, 1994. С. 605-612.

125 Ibid. 
In these circumstances, the Ukrainian Church found itself in a difficult position immediately after the Union of Brest: The Orthodox camp considered it to be a traitor, and therefore an enemy, while the Polish Catholic church continued to treat it as secondary and, consequently, lower. On the positive side, having received the new canonical status and being in direct subordination to the Pope, the Ukrainian union church was to be respected by both camps, or at least taken into account. More than that, it was headed by prominent people, by Metropolitan bishop Hipatius Poceij (1599-1613) and Josyf Veliamyn Rutsky (1613-1637), both of them made a significant contribution to the establishment of the Union and the maintenance of the church in the first half of the XVII century. The latter one made considerable efforts to end the hostility of the Ukrainian Churches and it was during his reign, when the bold project of Meletius Smotrytsky was born - to create the Kyiv Patriarchate, which would unite the churches and be subject to the Pope, while maintaining full autonomy. Two attempts to unite the churches during the councils, first in Kyiv (1628) and then in Lviv (1629), failed mainly because of the resistance of the Cossacks. Metropolitan bishop of the Orthodox Church Peter Mohila (Petro Mohyla) (1631-1647) was among the supporters of the possible Kyiv Patriarchate under the patronage of the Pope, he regularly contacted with Rome, but he was strongly opposed by both the Cossacks and the Orthodox clergy, the latter one appeared to be increasingly Moscow-leaning ${ }^{126}$.

After the Pereyaslav Military-Political Agreement was signed between Bogdan Khmelnytsky and Moscow in 1654, in 1685 the Kyiv Orthodox Metropolis was subordinated to the Moscow Patriarchate by force. Soon afterwards, all the northern and western eparchies of the Ukrainian Catholic Church fell under the Moscow influence. Due to the looming threat on the side of aggressive Moscow church, in the early XVIII century all the remaining eparchies of Ukraine and Belarus, which had recognized the Pope's rule, united into the Kyiv Orthodox Catholic Church. This was how the paths of the two Ukrainian Orthodox Churches diverged. In

126 Панас Кость, о. Історія Української церкви. Львів, 1992. С. 77-78; Пашук А. Українська церква і незалежність України. С.94-106, 126; Кальницький М., Малаков Д., Юркова О. Нариси з історії Києва. Київ, 2002. С. 107-109. 
1720 an important synod in Zamosc was held, and it marked a crucial milestone in the history of the Ukrainian Church as it finally defined its face. As P. Isaiv put it «it basically reformed the Uniate Church (the Union church) as an independent church unit under the auspices of the Catholic church. The former Uniate Church, which had been kind of faceless, became the Greek-Catholic Church of the Ukrainian

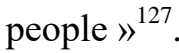

The Kyiv Metropolis was not the only one to go the difficult road to the union with Rome. At the same time, the Transcarpathian Eparchy faced similar difficulties. Despite the fact that Christianity appeared in this region earlier than in Kyiv, it was only at the end of the XIV century that the church was structured and taken into the care of the bishop of Przemysl, and in 1490 there was formed an eparchy subordinated to the Patriarchate of Constantinople. Under the influence of the Ukrainian Church, in the course of the Council of Uzhhorod in 1646, 400 priests (about half of the total amount of them in the region) decided to accept the union with Rome. Still, it was only in 1721, that the rest of the Orthodox clergy joined them. Thus, at the beginning of XVIII century, the Ukrainian Greek Catholic Church united all the eparchies of the western lands and the Right Bank of Ukraine ${ }^{128}$.

The majority of church and national history researchers believe that the Union of Brest comes second in the significance of the events in the history of Ukraine and Ukrainian Christianity, right after the Baptism in 988. The factors taken into account are the positive outcome for Ukraine, a natural result of objective processes in the historical development of the church, the context of the integration process of the Eastern and Western traditions. Metropolitan bishop Josyf Slipyj, a prominent constructor and historian of the Ukrainian Church, highly appreciated the Union of Brest. He emphasized its great importance for the revival and renaissance of the Ukrainian Church, and stated that the union had become an effective means of forming the Ukrainian people as a separate nation ${ }^{129}$. The Union of

127 Ісаїв П. Історія церкви. Енциклопедія украӥнознавства. Загальна частина. Т. 2. Київ, 1995. С. 613.

${ }^{128}$ Ibid. C. 616; Пашук А. Українська церква і незалежність України. С. 138-188.

129 Сліпий Йосиф, митрополит. Історія ... С. 30-113. 
Brest was certainly successful, if one takes into account its consequences, because as the modern historian Dmytro Stepovyk put it, it "corresponded to the general integration process, the interests of the Ukrainian people" 130 .

An important consequence of the Union of Brest was the upraise of one of the oldest monk orders - the Order of St. Basil the Great in Ukraine. Monasteries of this order led quite hermit lives, were subject to local bishops and played a small role in the social and church life of the region. After the union, Metropolitan Bishop Yosyf Rutsky united the monasteries, made them independent from bishops, put an archimandrite to head them, founded novitiates, developed theology and philosophy studies. The Metropolis of Kyiv was assisted by the Holy See, which approved all the measures taken. With the permission of Pope Paul V, since 1615 monasteries became the basis for new schools and colleges for Ukrainian youth to be established. The Basilians launched a network of printing houses, in particular in the cities of Suprasli, Univ, Uhertsi, and later on in Pochaiv, Lviv, Zhovkva $^{131}$. In the middle of the XVIII century, the OSBM Congregation in Ukraine united 130 monasteries and some 700 Basilian monks. The division of Poland in 1772 dealt a heavy blow to the Basilian Order and disrupted its structure in Ukraine. Monasteries that remained on the territory that Russia received were liquidated, and in 1839 there had been 190 of them, monasteries of the Kholmshchyna region were an exception, where they were destroyed in 25 years ${ }^{132}$.

At the end of the XVIII century, the once mighty Polish state was in a deep crisis. Taking advantage of the favorable geopolitical situation, neighbouring Russia, Austria and Prussia made three divisions of the Commonwealth of Poland in between 1772-1795 and erased from the map of Europe as a state. As a result of these events,

${ }^{130}$ Степовик Д. Множинність і єдність церкви. Київська старовина. 1993. № 5. C. 12 .

131 Ісаєвич Я. Українське книговидання: витоки, розвиток, проблеми. Львів, 2002. С. 276-285.

132 Стоколос Н. Українська церква у контексті конфесійних трансформацій на Правобережній Україні під владою Російської імперії. Украӥнський історичний журнал. 2002. № 4. С. 94-109. 
the Carpathian Terrain was incorporated into the Austrian Empire. Of all the new lands, Galicia was the largest and most neglected province ${ }^{133}$.

It was clear that Ukrainian Galicia (which constitute $71 \%$ of the population of 2 million people in total in 1773) in the hope of the best life welcomed the transition of power to Habsburgs, who were known as monarchs who sought to adapt the absolute monarchy to market relations and new trends in social and political life. The imperial reforms of Maria Theresa, Joseph II, Franz I reformed agrarian relations and triggered the cultural and educational awakening of Ukrainians. Still, in the lives of the churches there was a major change introduced, from that time on they were subordinate to the state. In 1784, in the former Dominican monastery in Lviv there was established a Greek Catholic seminary, the same year there were created Faculties of Philosophy and Theology in the Emperor Franz University of Lviv. Also there were issued special decrees in order to equate Ukrainian priests in rights and privileges with their Latin counterparts, education in Ukrainian language was allowed in schools $^{134}$.

The restoration of the Metropolis of Halych became a significant event in the ecclesiastical and religious life of the region and for the church in general. After the division of the Commonwealth, the outpost of the Kyiv Metropolis was on the territory belonging to the Russian Empire. Therefore, the bishops of Halych and Chelm had an idea to transfer the metropolis centre to the reconstructed city of Lviv, which had just broken through the medieval walls in order to become the center of dynamic events of a new historical era. Galician hierarchs repeatedly appealed to the emperor, especially after 1803, when Polish priests launched a campaign in order to subordinate Ukrainian eparchies to the Latin rule. However, it was only in 1808 when they received the Bull of Pope Pius VII and the emperor's permission to restore the Halych Metropolis in the largest

\footnotetext{
133 Верига В. Нариси історії України (кінець XVIII - початок XX ст.). Львів: Світ, 1996. С. 145.

134 Великий А. Г., ЧСВВ. 3 літопису християнської України. Т. VIII: XIX ст. Рим: Вид-во оо. Василіян, 1976. С. 48-49; Історія України. Львів: Світ, 1996. С. 159 .
} 
city of the region, in Lviv. The church was headed by Antin Anhelovich (1756-1814). The re-built archdiocese included Przemysl-Sambir-Sianotska, Kholm-Bielsk and Lviv-GaliciaKamenets eparchies ${ }^{135}$.

The Napoleonic wars and the Congress of Vienna in 1815 halted to a stop the implementation of the Austrian reforms concerning Galicia. Still, Metropolitan bishop Antin Anhelovich managed to resolve a number of issues that contributed to the spiritual and cultural progress of the country and to the organizational strengthening of the church. The Metropolitan bishop help to lay the foundation of the Teachers' Institute in Przemysl, defended the Orthodox calendar from changes in its system of holidays, and defended the right to receive education in a native language in the system of official teaching.

A particularly large-scale cultural and educational campaign was launched by Mykhailo Levytsky (1774-1858), first the Bishop of Przemysl, and then Metropolitan Bishop of Lviv in $1815-1858^{136}$. He also launched the building of schools, this was approved by the Przemysl synod, which decided there was an urgent need to restore the parish schools having been destroyed by the wars and to introduce Ukrainian into them. The Metropolitan bishop also succeeded in introducing a new statute for Austrian schools in Galicia. As a result, in the period between 1816 and 1819 there were 383 new parochial schools established in the province ${ }^{137}$. As a person responsible for the school and its development, M. Levytsky appointed a talented organizer and defender of the mother tongue of the priest Ivan Mohylnytsky, who had created the statute of the Przemysl Teachers' Institute. His initiative was also defining in the decision to establish a cultural-educational "Society of Galician Greek Catholic Priests for the Propagation of Enlightenment and Culture among the Faithful" in

135 Федорів Юрій, о. Історія церкви в Україні. Торонто, 1967. С. 258-259; Ададуров В. Львів у наполеонівську епоху. Львів: місто - суспільство культура : Збірник наук. праць / За ред. М. Мудрого. Львів: ЛДУ ім. І. Франка, 1999. C. 209.

136 Сапеляк Андрій, владика. Київська церква на слов'янському Сході. БуеносАйрес; Львів, 1999. С. 101.

137 Петрів І. Митрополит Михайло Левицький - перший кардинал-українець. Берестейська Унія (1596-1996). Статті і матеріали. Львів: Логос, 1996. С. 187. 
1816 in Przemysl, the task of this organization was to publish and distribute spiritual literature in the Ukrainian language. The same year, they printed "Bukvar" ("The ABC"), shortly afterwards Reverand I. Mohylnytsky compiled a grammar of the Ukrainian language. Later, in 1839, M. Levytsky, the first cardinal, who was Ukrainian by nationality, voiced the protest against the liquidation of the union by the Russian government on the Right Bank, Volyn and Belarus.

The next Bishop of Przemysl Ivan Snigursky continued to address problems of civil patriotism and enlightenment. Thanks to his persistent activity in 1832,411 public schools were operating in the eparchy ${ }^{138}$. In the 1820 s - 1830s, the young bishop I. Snigursky surrounded himself with a group of patriotic priests and intellectuals, who organized editions of books in Church Slavonic in Przemysl Greek Catholic printing house. As the result of their activity there appeared several books: "The Wedding of Rus"” by Josyf Lozynsky (1835), "The Alphabet and the Latin alphabet" ("Abetka i abetsadlo") by Markian Shashkevych ${ }^{139}$. I. Snigursky sought to create a number of new eparchial structures and a network of elementary schools in Nadsiannia $^{140}$.

Since 1815, the Metropolitan Greek Catholic Consistory launched a broad campaign to promote Ukrainian in schools. Because of the lack of teachers, Metropolitan bishop Mykhailo Levytsky gave the task to the parish priests to implement these activities. Still, the problem was that the Polish and Austrian authorities obstructed development and spread of Ukrainian Cyrillic writing because they did not consider the Rusyn language to be equal to Polish. Publicist speeches of Galician scholars, especially representatives of the Greek Catholic clergy, were of great importance for the formation of

\footnotetext{
138 Ясіновський Ю. Дяко-учительський інститут у Перемишлі. Перемишль $i$ Перемиська земля протягом віків. Перемишль; Львів, 2003. С. 249-259.

139 Перемишль і Перемиська земля протягом віків. Вип. 3. Перемишль; Львів, 2003. С. 22-23.

140 Лірвак 3-над Сяну: Перемиські друки середини ХІХ століття / Упор. В. Пилипович. Перемишль, 2001. 451 с.; Дух і ревність. Владика Снігурський та інші перемишляни / Упор. В. Пилипович. Перемишль; Львів, 2002. 498 с.
} 
national character and its identity, as well as protection of the mother tongue $^{141}$.

Despite his spiritual opponents efforts, Metropolitan bishop M. Levytsky issued three memorials (1817, 1821, 1830), concerning the "independence of the Ukrainian language". The Greek Catholic deans were supposed to supervise Ukrainian schools. Ukrainians also sought for the replacement of Roman Catholic chaplains in six Ukrainian schools in the region by Uniates (union priests) ${ }^{142}$.

The long-standing Polish domination deteriorated not only the Ukrainian language, historical memory, customary law, but also the intellectuals of the enslaved people. In the XIX century, according to the Ukrainian adversaries, there remained only "hlop and pip" (a common worker and a clergyman) in the Ukrainian province. Therefore, one these social strata gave a start to the national, cultural and political revival and this was a characteristic feature of the process $^{143}$. Consequently, it is only natural that priests were on the forefront of the national and cultural revival, as they were people with certain social status and had trust of the peasantry ${ }^{144}$.

A new stage of Ukrainian revival in Galicia was started in the 1830's by a group of young theologians, the "Ruska Trijtsia" (Rus' Trinity). Their activity aimed at protection of their national language was increasingly resembling the national liberation struggle. The "Ruska Trijtsia" actively promoted their mother tongue, considering it to be the main feature of the identity for people. In 1833, they compiled the first collection of works in the vernacular language (in the spoken language), it was called "Syn Rusi" ("The Son of Rus""), but it was banned from publication for ideological reasons. Their next collection "Zoria" ("The Morning Star") (1834) also was not published due to the censorship of a political nature, in particular because of M. Shashkevich's poems in which he called out to people

141 Великий А. Г., ЧСВВ. 3 літопису християнської України. Т. VIII: XIX ст. Рим: Вид-во оо. Василіян, 1976. С. 102-104, 105.

142 «Русалка Дністрова»: Документи і матеріали / Упор. Ф. І. Стеблій та ін. Київ: Наук. думка, 1989. С. 243-244.

143 Великий А. Г., ЧСВВ. 3 літопису християнської України. Т. VIII: ХІХ ст. Рим: Вид-во оо. Василіян, 1976. С. 113.

${ }^{144}$ Ibid. C. 113-114. 
to fight for their rights. Finally, in 1837, they managed to publish an almanac in spoken Ukrainian in the printing house of the Royal Hungarian University (Buda), it was called "Rusalka Dnistrova" ("The Nymph of Dniester") and had more than 200 copies $^{145}$.

The almanac "Rusalka Dnistrova" («The Nymph of Dniester») brought recognition to its publishers among the Slavic community and was highly appraised by the nationally active part of Galician society ${ }^{146}$. It is clear that the reaction of the Austrian authorities and the Polish administration in Galicia was totally opposite. The collection was confiscated and almost completely destroyed according to the special order of the Galician governor ${ }^{147}$.

Representatives of the Transcarpathian clergy also showed interest in the ethno-national heritage. In particular, the monk of the Mukachevo monastery, Ioannykij Bazylovych, wrote the first scientific history of Transcarpathia - "A Short Sketch on the Foundation of Fedir (Fyodor) Koriatovych" (Kosice, 1799-1805), in which he substantiated the authenticity and identity of the local Ruthenians as an integral element of the Slavic part. Subsequently in 1830, the famous ecclesiastical activist Mykhailo Luchkai published his "Grammar of the Slavic-Rus' Language" in the city of Buda and shortly afterwards (1843) there appeared a six-volume "History of the Carpathian Ruthenians". Works of Transcarpathian authors were also published in the cities of Przemysl, Lviv, and Kolomyia ${ }^{148}$.

In 1848, the whole of Europe was ignited by the revolutionary movement, which became known as the "spring of the nations". The Austrian Empire had its most extreme case and therefore experienced several groundbreaking changes. The new Austrian government declared democratic freedoms of conscience and religion, freedoms of the press, assembly, organizations. On April 17, Emperor Ferdinand I signed a law to abolish serfdom, to free peasants from

145 «Русалка Дністрова»: Документи і матеріали. С. 75, 98; Шашкевичіана. Збірник наукових праць. Вип. 1-2. Львів; Броди; Вінніпег: Просвіта, 1996. С. 230.

146 Демкович-Добрянський М. Українсько-польські стосунки у XIX сторіччі. Мюнхен, 1969. С. 23.

147 Центральний державний історичний архів України у м. Львові (далі ЦДІАУЛ). Ф. 146. Оп. 7. Спр. 2772. Арк. 123-124.

148 Пап С. Історія Закарпаття. Т. 3. Івано-Франківськ, 2003. С. 140-151. 
duty, and to grant them liberty; on April 25, 1848 there was a proclamation of the constitution and declaration of the start of general elections to parliament, it was also allowed to form the National Guard. This revolution triggered democratic transformations and therefore led to the unprecedented rise of the national movement in Galicia, giving it its political character. Struggling with the Polish separatism, the Austrian government, in particular the governor of Galicia, Count F. Stadion, was forced to treat the Galician Ruthenians (this was how local Ukrainians called themselves then) well, as they were still loyal to Vienna and stated their modest demands in the petition to the Emperor. This petition was dated April 19 and the delegation was headed by Mykhail Kuzemsky, a wingman. The demands were moderate indeed: to introduce the Ukrainian language in schools, to issue state orders in the Ukrainian language, to allow Ukrainians to run for positions in the self-governing bodies, to guarantee equal rights and privileges to the Greek Catholic clergy in comparison to the Latin ones ${ }^{149}$.

The course of social and political events in Galicia clearly demonstrated the desire of the Ukrainian Church to participate in the national movement. At that time, the church underwent transformation from a spiritual force into a social institution ${ }^{150}$. It should be taken into account that the contemporaries of the events treated the cultural and political uprising of Galicia, recognition of its Ukrainian essence, as well as the rapid rise of the national liberation movement during the revolutionary events of 1848 quite differently, especially in the context of the Ukrainian geopolitical position in between the West and the East, therefore their ambiguous views resulted in different directions of church policy ${ }^{151}$. At that time, the clergymen became almost the only mediator and representative of the population in their relations with the state authorities.

\footnotetext{
149 Головна Руська Рада. 1848-1851. Протоколи засідань і книга кореспонденції / За ред. О. Турія. Львів, 2002. С. Х-ХХХІІ; Великий А. Г., ЧСВВ. 3 літопису християнської України. Т. VIII: ХІХ ст. Рим: Вид-во оо. Василіян, 1976. C. 114-115.

150 «Русалка Дністрова»: Документи і матеріали. С. 247-251.

151 Турій О. Конфесійно-обрядовий чинник у національній ідентифікації українців Галичини в середині XIX століття. Записки НТШ. Т. CCXXXIII. Львів: НТШ, 1997. С. 75.
} 
Thus, it is quite natural that the Supreme Ruthenian Council (SRC), the first Ukrainian political organization in Galicia, established on May 2, 1848, was headed by the authoritative Bishop of Brest Hryhoriy Yakhimovych (1792-1863), and his vice was Miykhailo Kuzemsky (1809-1879), also a canonic clergyman, and the secretary was the experienced reverand, Mykhailo Malynovskyi (1812-1894). The majority of Council members were people related to church. In its manifesto to people, the leadership of the SRC declared the unity of a 15 million (Ukrainian) "great Ruthenian people" who "spoke the same language" and had a powerful state in the past. The main directions of the program of the organization included preservation of the Greek Catholic faith and rite as well as granting the church the same rights as other churches had, democratization of public education and implementation of the native language in all state and public institutions, fighting for and defense of the constitutional rights and freedoms of the people ${ }^{152}$. The first Ukrainian magazine "Zorya Halytska" («The Star of Halych») became the spiritual body of the Council. There were rural, school, financial and other departments under the Council. In the districts and dean's offices, they formed 50 so-called "smaller" (deanal) councils, which were led by clergy representatives. In July 1848, district councils began to appear in the cities of Berezhany, Zhovkva, Kolomyia ${ }^{153}$.

The Galician clergymen actively participated in the first elections to the Austrian Parliament in 1848. During the election campaign, the Supreme Ruthenian Council relied mainly on their priests. In the end, even though, as the result of the election, Ukrainians managed to get only 39 (including 27 peasants and 9 clergy) seats out of the 96 mandates given to Galicia, this was a certain achievement, because from that time on they could use the parliament to be heard and representatives to solve their problems. The Ukrainian Parliamentary

152 Великий А. Г., ЧСВВ. 3 літопису християнської України. Т. VIII: XIX ст. Рим: Вид-во оо. Василіян, 1976. С. 118; Верига В. Нариси історії України (кінець XVIII - початок XX ст.). Львів: Світ, 1996. С. 167; Зоря Галицьька. 1848. 15 травня.

${ }^{153}$ Головна Руська Рада. 1848-1851. С. XXIV-XXV. 
Club was formed and headed by Bishop Hryhoriy Yakhymovych ${ }^{154}$. Under his leadership, Ukrainian ambassadors created four memorials on national relations in the province, as well as a petition with 15,000 signatures on the issue of division of Galicia into Ukrainian (Eastern) and Polish (Western). The proposal was to have a different governor in Eastern Galicia, and on the territory of the region Ukrainian would be introduced in institutions, schools, temples, while Galician Ukrainians were to be given positions in state authorities. Although the emperor and his government generally acknowledged the general validity of the Ukrainian project, they did not dare to implement it because of Poles.

One of the most prominent events that took place in the course of "the Spring of Nations" was the first Prague Slavic Congress, which was convened in Austria in June 1848 and during which, according to the aims of its organizers, they were to formulate the principles of the Austrian Slavs' interaction - to secure their national rights, to oppose German centralism and to transform the Habsburg Empire into a federal association. The Galician delegation, led by priest Hryhoriy Hynylevych (1809-1871), highlighted the problem of the division of Halychyna (Galicia), stressed on the importance of introduction of the Ukrainian language, and emphasized the ethnic equality of Ukrainians among other peoples. In October 1848, despite the disapproval of the Austrian administration of Galicia, the Supreme Ruthenian Council convened a "congress (meeting) of Ruthenian scientists" in Lviv. It was attended by 119 representatives of the Galician intelligentsia (about $90 \%$ of them were priests under the patronage of M. Kuzemskyi). The congress passes an important decision, they decided to establish the first scientific society "Ruthenian Matytsia" in Lviv. The statutory task of this organization was to publish and spread "good and useful books for strengthening of faith and morality, spreading knowledge, development of eloquence, calligraphy, technology, economy and pedagogy"155.

\footnotetext{
${ }^{154}$ Мудрий Софрон, о. Нарис історії церкви в Україні. Рим; Львів: Вид-во оо. Василіян, 1995. С. 311.

${ }^{155}$ Великий А. Г., ЧСВВ. 3 літопису християнської України. Т. VIII: XIX ст. Рим: Вид-во оо. Василіян, 1976. С. 119; Сухий О. Від русофільства до
} 
It is also worth mentioning that the Supreme Ruthenian Council managed to get back some of the national symbols: the blue-yellow flag, which is the flag of modern Ukraine, and the coat of arms of the Halych-Volyn princes - a golden lion against a blue background; also they founded a prominent institution for conducting cultural and educational work in Lviv - Narodny Dim (a communal hall), which operated until $1939^{156}$.

In connection to the above-mentioned events, it is worth to mention activity of the conscious compatriot Vasyl Podolynskyi, who was the Lemko priest from the village Vetlyny, but who tried to contribute to the creation of the Ukrainian state. In the summer of the same year he published a book "The Word of Precaution" (in Polish), in which he detailed the future national-state concept of the region's development. Considering the four perspectives of the future of Galicia (as a part of Austria or Poland, or Russia, as an independent state), the author came to the conclusion that the only change for his shattered people to preserve their nation was to have a united independent Ukrainian state, which should include Galicia. Other ways brought national destruction ${ }^{157}$.

Unfortunately, as early as the beginning of 1850's, the reactionary regime gained its powers back in Austria, and consequently set out to return to absolutism. The constitutional rights of Ukrainians were abolished. The post of governor of Galicia was taken by Count A. Golukhovsky and his entry into office meant strengthening pressure on the Greek Catholic Church and leaders of the SRC. The latter one was forced to dissolve on June 30, 1851. The omnipotent Polish administration ignored the draft of the governmental decree about the division of Galicia into Ukrainian and Polish ones. The Ukrainian language was gradually ousted from schools. All these facts led to the spread and popularization of Russophilism ("Moscowphilism") primarily as a protest against the increase of the forced Polish and Latin influence on Ukrainians. On the other side, Russia

\footnotetext{
москвофільства. Російський чинник у громадській думці та суспільнополітичному житті галицьких українців у XIX столітті. Львів, 2003. С. 250-311. ${ }^{156}$ Галицькі митрополити. Біографічний довідник. Львів: Логос, 1992. С. 32. 157 Франко І. Панщина та їі скасування 1848 р. в Галичині. Франко I. Зібрання творів. Т. 47. Київ, 1986. С. 122.
} 
was pursuing its own goals, that's why it supported this trend not only morally but also financially ${ }^{158}$. During this difficult period, responsibilities of the patriotic clergy increased. In 1856, Mykhailo Levytsky (1774-1858) received the title of Cardinal from Pope Pius IX. He was the first among the Galician metropolitan bishops to be promoted, and that led to certain uplifting of the reputation of the Greek Catholic Church and its influence on the solutions of some national-religious problems of Western Ukrainians.

After the defeat of Austria in the war with Piedmont (1859) and the threat of a new national liberation movement in the empire, Austrian government was forced to return to the constitution of 1860 , which was somewhat liberalized the following year. Using the defeat of Austria in its war against Prussia, the Hungarians gained the same status as Austrians and their own parliament. Subsequently, in 1867, the Austrian-Hungarian Empire was formed ${ }^{159}$. Austria saved its influence on 17 crown lands, including Galicia and Bukovina; its constitution and laws proclaimed the equality of all peoples of the empire, as well as the right to preserve and use their mother tongue in schools and public institutions. Still, in reality, Ukrainians did not get the declared rights. That is why the Ukrainian representatives and ambassadors in the Vienna Parliament and in the Diet of Galicia and Lodomeria fought hard for the realization of civil rights. An important role in this struggle belonged to Hryhoriy Yakhymovych, who headed the Metropolis of Halych in 1860 and tried to support the ambassador priests in every way possible.

The elections to the Diet of Galicia and Lodomeria reflected the real social influence of the Greek Catholic clergy, which had to be drawn into political battles, as there was no other social force capable of taking the political lead in Ukrainian society at that time. At the beginning of 1861 the bishop of the Greek Catholic Church addressed the clergy and religious followers with a vast explanation of the essence of the elections and tasks of the elected representatives in the local parliament. He appealed to their wise choice of "sensible, intelligent, religious, conscientious men who had a distinct

158 Нариси з історії суспільних рухів та політичних партій в Україні (XIX ХХ ст.). Львів: Світ, 2001. С. 18-19.

${ }^{159}$ Цьольнер Е. Історія Австрії. Львів, 2001. С. 399-409. 
commitment to our Ruthenian cause" ${ }^{\$ 60}$. However, having learned their bitter lesson in 1848 , the clergy tried to secure their own proper representation in the elected bodies of state power. Therefore, among the 77 candidates proposed by the Ruthenian election committee headed by H. Kuzemsky, who was originally from Krylos, there were 58 priests, 19 representatives of the secular intelligentsia and no peasants. Yet the election results brought disappointment to the clergy: among the elected people there were only 22 priests, 8 representatives of the secular intelligentsia and 16 peasants, who received ambassadorial rights ${ }^{161}$. Reverand Volodymyr Terletsky blamed it on the Polish nobility, he claimed they discouraged peasants from voting for their pastors, and that fact accounted for the poor representation of the clergy in the outcome of the election ${ }^{162}$. However, the working processes of the Diet of Galicia and Lodomyria proved there were basic differences between the positions of the clergy and the peasantry in socio-economic issues, especially when they discussed the problem of eliminating the natural and monetary tributes of the parishioners in favor of priests, and an issue of regulating the payment for the rites ${ }^{163}$.

Among the ambassadors to the State Council in Vienna, there was Reverend Ivan Ozarkevych (father of the writer Natalia Kobrynska) who consistently defended the interests of voters since 1873 . Out of the 16 Ukrainian ambassadors of that time, 11 people were priests. I. Ozarkevych became the leader of the Galician deputation, which reported to the emperor on the arbitrariness of local authorities on December $12,1895^{164}$. Shortly afterwards, in 1908 , there were elected

\footnotetext{
160 Турій О. «Попи і хлопи»: Соціальна «доктрина» греко-католицького духовенства i національно-політична мобілізація українського селянства Галичини в середині ХІХ століття. Ковчег. Ч. 3. Львів, 2001. С. 314-315.

161 Ibid. C. 316-317; Чорновол I. Українська фракція Галицького краєвого сейму 1861-1901. Нарис з історії українського парламентаризму. Львів, 2002. С. 82-135.

162 Терлецький В. И наше слово о виборах и сойм. Слово. 1861. 11 травня.

163 Турій О. Соціальний статус і матеріальне становище греко-католицького духовенства Галичини в середині ХІХ ст. Ковчег. Ч. 2. Львів, 2000. С. 115-118.

164 Королько А. Культурно-просвітницька і громадсько-політична діяльність о. Івана Озаркевича (1826-1903) в контексті українського національного відродження. Питання історії України. Чернівці: Технодрук, 2013. Т. 16. C. 37-44.
} 
the following people to the Vienna parliament from the National Democratic Party: priests Josyf Folysa (Lviv district), Stepan Onyshkiewicz (Sudova Vyshnia, Sambor) and Tyt Voinarovsky (Kolomyia district), who divided 30000 morgens of land among the farmers of Pokuttya ${ }^{165}$.

Activity of the Metropolitan bishop H. Yakhymovych started from a series of protest statements to the emperor with the following demands: to introduce the spoken Ukrainian language in schools with the majority of Ukrainian learners, to teach it in secondary schools, to implement its usage in administrative bodies and public institutions; to make fluency in Ukrainian an obligatory criterium while filling in government positions. Responding to these statements, the government agreed to grant free usage of the Ukrainian language in Galicia, and agreed to publish books in the spoken language of the people. While paying great deal of attention to the development of schooling and education in general, Metropolitan bishop H. Yakhymovych tried to fight two opposing social movements that seized schools and churches as well. These polar opposites were great affection to and subsequently influence from Polish Latinism and Russophilism, tendencies which found lots of followers among Greek-Catholics in the late 1860s - early 1870s.

Metropolitan bishop Spiridon Lavrynovych (elected in 1863) continued the course of $\mathrm{H}$. Yakhymovych, aimed at the further building of the network of public schooling, and making the idea of national identity of Ukrainians stronger. This case was largely contributed to by the so-called "Concordia", a declaration of inter-rite mutual understanding between Poles and Ukrainians in Galicia; it was approved by Pope Pius IX, the emperor, Latin and Ukrainian bishops, and it was in full operation until the collapse of the Austro-Hungarian Empire in 1918 and the emergence of two independent states, the Polish state and the Western Ukrainian People's Republic on its remnants. The main achievement of "Concordia" was the prohibition for Latin-Catholic Ukrainians and Greek-Catholic Ukrainians to switch/change their rite. In this way both rites in Galicia remained invariable in numbers, their territories were inviolable and their

165 Арсенич П. Греко-католицькі священики в національних змаганнях українців Галичини. Нова Зоря. 1991. Квітень. Ч. 5-6. 
identities were preserved. These all acted for the national and ecclesiastical interests of Ukrainian Galicia. It normalized publicchurch cooperation and relations inside the population of the region $^{166}$.

Traditions of the "Ruthenian Trinity" ("Ruska Triitsia") and of the "Spring of Nations" of 1848 were further strengthened in the Galician society by the intrigues of Polish government and church circles as well as by organized attacks and tangible successes of Russophilism in the $1860 \mathrm{~s}^{167}$. The Greek Catholic Church also gradually strengthened its position. Its main stronghold, the Eparchy of Lviv, had 1.3 million believers in most territories of Galicia and Bukovina. Another eparchy, Eparchy of Przemysl which belonged to the Halych Metropolis had 855,000 Greek Catholics ${ }^{168}$. About 1,200 priests worked tirelessly among the Galician peasantry ${ }^{169}$. Besides religion, literary works and arts contributed to the growth of the national and united identity of the Galicians, especially works of writers from the Dnieper region, in particular patriotic poetry of Taras Shevchenko. Gradually the center of the pan-Ukrainian national movement shifted to Galicia, and the region got the name "Ukrainian Piedmont".

Occupying a prominent place in the socio-cultural processes of the national movement, the patriotic clergymen tried to resist the assimilation processes and attempts to alienate rural culture from the urban. Metropolitan bishop Josyf Sembratovych (1870-1882) launched a large-scale struggle against immorality and drunkenness. Purposeful sermons in churches, missions on the periphery, an established network of fraternities in combination with active cultural and educational work produced tangible results, they improved reputation of the church and at the same time contributed to

166 Великий А. Г., ЧСВВ. 3 літопису християнської України. Т. VIII: XIX ст. Рим: Вид-во оо. Василіян, 1976. С. 154.

167 Аркуша О., Мудрий М. Русофільство в Галичині в середині XIX - на початку XX ст.: генеза, етапи розвитку, світогляд. Вісник Львівського університету. Серія історична. Вип. 34. Львів, 1999. С. 231-268; Турій О. Греко-католицька церква та українська національна ідентичність у Галичині. Ковчег. Ч. 4. Львів, 2003. С. 67-85.

168 Федорів Юрій, о. Історія церкви в Україні. Торонто, 1967. С. 311

169 Верига В. Нариси історії України (кінець XVIII - початок XX ст.). Львів: Світ, 1996. С. 200. 
the promotion of Christian morality and national upbringing. Despite the obstacles on the part of the Polish administration, Ukrainian schooling system was developing. This was largely facilitated by the school reform of the 1860s-1870s, having been carried out by the Austrian government under pressure from Ukrainian ambassadors and the Greek Catholic hierarchy. There was introduced compulsory primary education of children in their native language, so in the academic year 1869/1870, there were 1293 Ukrainian public elementary schools in operation, and by the end of the XIX century the amount of literate Ukrainians reached nearly $30 \%{ }^{170}$.

The progress of the national-cultural life was definitely marked and it was manifested by the foundation of the regional society "Prosvita" ("Enlightment"), which was the most popular organization in terms of amount of members. This scientific society was headed by the son of a Greek Catholic priest, Anatol' Vakhnyanyn (18411908), and the head was chosen in the course of the first meeting in Lviv, on December 8, 1868. The main task of "Prosvita" was to popularize adult education by means of publishing books and organizing a wide network of reading rooms in Ukrainian villages ${ }^{171}$. In 1912, it had 77 branches in Galicia, and its network could included 504 reading rooms and 2,664 libraries, hundreds of amateur art groups, which brought together about 200,000 members. According to the calculations of Lviv historian Volodymyr Pashuk back in 1914 "Prosvita" united 36,5 thousand members ${ }^{172}$. One of the characteristic features of the society "Prosvita" was that its peripheral branches and rural centers were mostly headed by priests.

Galician clergy took an active part in founding of a range of national societies and communities, which had to care about the wellbeing and welfare of citizens. They were two priests from village Olesko (near the town of Zolochiv), who founded the regional agricultural society "Rural Master" in 1899. Their names were Yulian

170 Стеблій Ф. Духовний П'ємонт українців. Львівщзина. Історико-культурні та краєзнавчі нариси. Львів: Центр Європи, 1998. С. 208-209.

171 Товариство «Просвіта» у Львові. Статути / Упор. В. Пашук. Львів, 1999. $272 \mathrm{c}$.

172 Пашук В. Товариство «Просвіта» у Львові. Львів. Історичні нариси. Львів: Інститут українознавства ім. І. Крип'якевича НАНУ, 1996. С. 245. 
and Toma Dutkevych and the aim of the organization was to protect peasants from the arbitrary rule. This organization stood on the forefront of the farmers' protection; it contributed to the educational and economic culture, as well as provided gardeners, farmers and beekeepers with necessary information ${ }^{173}$.

Readers of the region greatly appreciated literary and publicist works of the priests who were members of the "Prosvita" organization. The list of these popular authors included the names of Tyt Blonsky (1830-1897), Volodymyr Herasymovych (1870-1940), Ivan Hushalevych (1866-1934), Vasyl Zalozetskyi (1933-1915), Vasyl Il'nytskyi (1823-1895), Dmytro Yosyfovych (1867-1939), Bohdan Kyrchiv (1856-1900), Yurii Kmit (1872-1946), Mykhailo Petrushevych (1859-1895), Ivan Pleshkan (1866-1933) and others. ${ }^{174}$

There were also many talented composers among the clergymen. They were: Mykhailo Verbytsky (1819-1870), Porfyrii Bazhanskyi (1830-1920; the author of the opera "Dovbush"), Sydir Vorobkevych (1836-1903, Chernivtsi), Teofil' Bobrynskyi (1848-1882), Mykola Kumanovsky (1846-1924), Viktor Matiuk (1862-1902). There were also a lot of pedagogical workers, actors, ethnography scientists, librarians and museum workers ${ }^{175}$.

There were organized archeological and bibliographical exhibitions to celebrate the 900th anniversary of introduction of Christianity to Rus' and the 40th anniversary of the reign of Monarch Franz-Joseph. These events were organized with the great assistance and participation of church hierarchs and representatives of the Stauropegian Institute (which was established in 1788 in Lviv) ${ }^{176}$.

173 Злупко С. На чатах рідної землі: Євген Храпливий - учений, організатор, патріот. Львів: ЛНУ ім. І. Франка, 1999. С. 264-269.

174 Арсенич П. Греко-католицькі священики в національних змаганнях українців Галичини. Нова Зоря. 1991. Квітень. Ч. 5-6.

175 Загайкевич М. Михайло Вербицький: сторінки життя і творчості. Львів, 1998. 148 с.; Арсенич П. Греко-католицькі священики в національних змаганнях українців Галичини. Нова Зоря. 1991. Квітень. Ч. 5-6; Грабовецький В. Ілюстрована історія Прикарпаття. Вид. 2. Т. 3. Івано-Франківськ: Нова Зоря. C. 373-376.

176 Орлевич I.В. Діяльність Львівського Ставропігійського інституту (кінець XVIII - 60-i pp. XIX ст.). Автореф. дис. на здобуття наук. ступ, канд. іст. наук. Львів, 2000. 20 с.; Киричук О.С. Ставропігійський інститут у громадському житті Галичини (друга пол. ХІХ - поч. ХX ст.). Львів, 2001. 19 с. 
A year later, using the exhibits of the previous event as a basis, there was founded the Museum of the Stauropegian Institute, which had 60 manuscripts, 243 old printed books, 313 objects of church art presented $^{177}$.

The church leadership supported the scientific projects of the Shevchenko Scientific Society, in particular its Archaeographic Commission (it was founded in 1896 by Mykhailo Hrushevsky, and its vice-president was Ivan Franko), which launched a broad research program on the publication of "Acts to the Church Union". Thus, a series of articles on the history of the church appeared on the pages of the "Notes of the Shevchenko Scientific Society": about the life of village parishioners in Galicia in the 18th century (M. Zubrytsky), reviews on the printed pastoral messages of bishops of Lviv (I. Levytsky), and others ${ }^{178}$.

The Galician clergymen made a significant contribution to the Ukrainian cooperative movement. In 1883, Yevhen Dutkevych, a priest from Lviv, co-founded the "People's Trade Association", which spread its influence rather quickly and in a short time had its branches all over Galicia; soon afterwards there were hundreds of rural shops to work with it. Subsequently, rural dwellers created lots more cooperatives unions in their villages, in particular there was established a dairy cooperative union. Its creator was a priest from the Stryi region, Ostap Nizhankivsky. Soon, the dairy union, known in the Eastern Europe under the name "Maslosoiuz", was founded in the same county.

Timely creation of political institutions for civil society became another indication of the maturity of the community, of its active nationalization, as it proved positive politicization of the national movement. In 1890, a Rus'-Ukrainian Radical Party was formed in Lviv $^{179}$. Shortly afterwards there appeared the centrist Ukrainian

177 Скочиляс I. Дослідження візитаційної документації Львівської єпархії у Галичині в другій половині ХІХ - першій половині XX століть. Ковчег. Ч. 3. Львів, 2001. С. 470-489.

178 Ibid.

179 Нариси з історії суспільних рухів та політичних партій в Україні (XIX ХХ ст.). / за заг. ред. Я.Й. Малика. Львів: Світ, 2001. С. 23. 
National Democratic Party (1899) ${ }^{180}$ and the Ukrainian Social Democratic Party (1899), which was Marxist-leaning. With a noticeable assistance from Metropolitan bishop Sylvester Sembratovych the Ruthenian-Ukrainian Christian Union was formed in 1896 and it became a Ukrainian party of clerical nature. Soon after its creation, the Ukrainian National Democratic Party took the lead in the political movement of the region. It was the most powerful and influential one and defended the slogans of democratic nationalism, social reforms, as well as stood for political, economic and cultural independence, the division of Galicia into Polish (Western) and Ukrainian (Eastern), establishment of a national cultural autonomy within the Austrian-Hungarian state, but with the separate local parliament and administration.

There was one more organization closely connected with the Greek Catholic Church. It was the Catholic Union, and since 1911 it was reorganized into the right wing nationalistic Christian Social Party. This party was headed by a talented educator, historian and political figure Alexander Barvinsky (1847-1926) - ambassador of the Galician Diet and the Austrian Parliament, a full member of the Shevchenko Scientific Society, who was at the same time an editor of the party newspaper "Ruslan"181. He promoted the policy of the "new era", that is, understanding between Ukrainians and Poles in Galicia, and the possibility of national-political and cultural-economic development of both peoples under the auspices of the Austrian state $^{182}$.

The multi-vector process of the national movement in Galicia also included the wide-scale activity of the Order of St. Basil the Great. It is worth noting that after the Austrian government had banned to maintain relations with Rome, a lot of monasteries and monastic schools were closed, there was a restriction for the number people

\footnotetext{
180 Расевич В. Українська національно-демократична партія (1899-1918 рр.). Автореф. дис. на здобуття наук. ступ. канд. іст. наук. Львів, 1996. С. 17.

181 Аркуша О. Олександр Барвінський (до 150-річчя від дня народження). Львів, 1997; Олександр Барвінський. 1847-1927. Матеріали конференції, присвяченої 150 річниці від дня народження Олександра Барвінського. Львів, 2001.

182 Кугутяк М. Галичина. Сторінки історії. Івано-Франківськ, 1993. С. 64-74; Аркуша О. Галицький сейм: виборчі кампанії 1889 і 1895 pp. Львів, 1996. C. 11-36.
} 
who wanted to become monks, and monasteries became subordinate to local bishops, therefore the Order was in decline until the 1880's, with only 14 monasteries remaining in Galicia and 60 monks residing there $^{183}$. The renewed process of national revival in Galicia and the effective activity of the Greek Catholic Church prompted the leadership of the Order to make radical reforms. Supported by Metropolitan bishop Josyf Sembratovych of Galicia, the proto-abbot of the Galician province of Order of St. Basil the Great Rev.Fr. K. Sarnytskyy sent to Pope Leo XIII the draft of a reform, and it was approved by the Vatican. Subsequently there came the Apostolic Letter to Lviv (dated from May 12, 1882) with a "Special Protection" outlining the reform program for the Order. According to the program, the Order of St.Basil the Great was subordinated to Rome directly, and the Order of Jesuits was supposed to see the implementation of the Letter through. The main tasks of the Order could be listed as follows: to promote and strengthen the unity of Galicia's Ukrainians with the Holy See and the Catholic faith; to take part in education and religious education of the Ukrainian people, in particular youth; to continue education and training of highly educated, devoted to church and people priests, pastors, figures of the church hierarchy ${ }^{184}$. The reformation process started with the opening of the novitiate in Dobromyl, where new students studied all year long, afterwards they studied philosophy, theology, rhetoric in the monasteries of Galicia for three years, and thus they could become priests.

The Galician public and the Greek Catholic clergy watched the reformation of the Order of the Basilians without enthusiasm, as they believed that the Jesuits would definitely denationalize it. As a result, the reform was delayed until 1911. However, the reformation proved to be effective, it saved the Order and the Greek Catholic Church received many outstanding members. In 1888 the future Metropolitan

183 Ваврик М., ЧСВВ. Нарис розвитку і стану Василіанського Чина. XVII ХХ ст. Рим, 1979. С. 52-53.

184 Апостольський лист Папи Лева XIII «Про реформу Чину св. Василія Великого Української нації в Галичині». Записки ЧСВВ. С. 2. Т. 11. Рим, 1982. C. 351 . 
bishop Andrey Sheptytsky joined its ranks as a future monk ${ }^{185}$. The monks of the Order of St. Basil launched extensive apostolic work in Galicia: during 1889-1893 they carried out about 200 missions, mostly in villages. They founded religious communities and organizations popular among Galicians, and then worked there with great results. The Apostleship of Prayer had about 500,000 members, the Marian Wives amounted to 25,000. On the eve of World War I, 16 Basilian monasteries with 211 monks and 23 novices were operating in the country ${ }^{186}$.

Moral and religious education in the region as well as raising the national consciousness of the Galician people greatly relied on the publishing activity of the Basilian Order ${ }^{187}$. The main center of the Basilian Order' book publishing was the town of Zhovkva, there, in the summer of 1895, a large printing house was built at the monastery, and in 1898 they already had their own publishing house. Among the co-founders of the latter, there was the abbot of the Basilian monastery of St. Onuphrius, Andrey Sheptytsky. At the end of the XIX century, the order of the Basilians used to publish two dozen books annually, the number of copies of some of them reached 10-12 thousands, while the monthly edition "Missioner" ("The Missionary"), published since May 1, 1897, had 20 thousand copies $^{188}$.

It is worth noting that the last decade of the XIX century was characterized by a large flow of Galician emigrants going over the ocean (about 80 thousand people). The next decade their number amounted to more than 224 thousand, and the majority of them were peasants. Under these circumstances, it was the Basilian Order, in

185 Патрило І. Нарис історії Галицької провінції ЧСВВ. Записки ЧСВВ. Т. II, секція 2. Рим, 1982. С. 67-68; Добромильська реформа і відродження Української церкви. Львів: Місіонер, 2003.

186 Ваврик М., ЧСВВ. Нарис розвитку і стану Василіанського Чина. XVII ХХ ст. Рим, 1979. С. 64-65; Історія релігії в Україні. Т. 4. Католицизм. Київ, 2001. C. 353-371.

187 Архів Святоонуфріївського монастиря Отців Василіан (Львів). Постуляційний фонд.

${ }^{188}$ ЦДІАУЛ. Ф. 684. Оп. 1. Спр. 1563. Арк. 70-93; Лозинський М. Видавнича діяльність Василіянського Чину в умовах Добромильської реформи і в сучасний період. Добромильська реформа $і$ відродження Української церкви. Львів: Місіонер, 2003. С. 146-151. 
particular from the Galician Province, which sent missionaries to the new Ukrainian settlements in Canada, the United States, Brazil and Argentina. At the beginning of the XX century, all of them united in two overseas missions (in Canada and Brazil consequently), and they were under the rule of Bishop S. Ortynsky, who left for the United States after some time ${ }^{189}$.

Among the other prominent people, it was Metropolitan bishop Sylvester Sembratovych (1885-1898), who greatly facilitated the successful development and activity of the Basilian Order (the Order of St. Basil the Great) in the Galician province. He promoted the concept of the Ukrainian nation as a confessional community, initiated reforms that had to bring the Greek Catholic Church closer to the Western traditions and to restore the union in the Dnieper region $^{190}$.

During the rule of Metropolitan bishop S. Sembratovych there happened two significant events in the life of the Greek Catholic Church. In 1885 the Stanislav Eparchy was finally established. Its first bishop was the rector of the Theological Seminary in Vienna, a prominent theologian and historian of the Ukrainian Church, Reverend Yulian Pelesh, the person who granted priesthood to Andrey Sheptytsky. His residence was in the restored Holy Resurrection Cathedral. During 1891-1896 he was the Bishop of Przemysl. Also Yulian Pelesh was the author of the two-volume "History of the Union of the Ukrainian Church with Rome" (1880). The second Stanislav Greek Catholic bishop was Y. Kuilovsky, who ruled from 1891 to 1899 . He was followed by A. Sheptytsky (from 1899 to 1901), then by H. Khomyshyn (from 1901 to 1945), and by Assistant Bishop J. Liatyshevsky in 1929-1945 ${ }^{191}$. In general, at the end of the XIX century, the Metropolis of Galicia had five eparchies on the territory of the Ukrainian lands, which belonged to AustrianHungarian state. They were: Lviv-Galicia-Kamenetsk, which was

189 Ваврик М., ЧСВВ. Нарис розвитку і стану Василіанського Чина. XVII XX ст. Рим, 1979. С. 64-65; Історія релігії в Україні. Т. 4. Католицизм. Київ, 2001. С. 67-68.

190 Чорновол I. Українська фракція Галицького крайового сейму 1861-1901. Львів, 2002. С. 258-259; Сухий О. Від русофільства до москвофільства. C. 176-352.

191 ЦДІАУЛ. Ф. 358. Оп. 2. Спр. 4. Арк. 1-7; Спр. 10. Арк. 1-2; Полєк В. Духовна освіта на Прикарпатті. Нова зоря. 1991. Листопад. Ч. 33-34. 
ruled over by the Metropolitan bishop with the help of the Assistant Bishop, Przemysl-Sambir-Sianotsk, Stanislav, Mukachevo-Uzhhorod and Presov.

The second notable event of the period was the Synod of Lviv which was held in September-October of 1891. Among the people who participated there were three bishops, 160 priests and a papal legate. This synod organized the ecclesiastical rule of law, the judiciary and the liturgy, assured faithfulness of the Greek Catholics to the Holy See. In general, it helped to revive national life in the church, religious and social-political spheres ${ }^{192}$.

After the Synod of 1891, the spiritual and socio-political life of Greek Catholics became more active. Due to the efforts of the church, there were founded various social and religious structures, which included the Missionary Community of St. Paul; The Saint Peter Community of Aid to the Poor Parishes; The Institute of St. Yoshaphat for youth education; charity organizations of the Servant Sisters, who took care of children and the senior people. The Catholic Ruthenian-Ukrainian Union, led by Olexandr Barvinsky, was of a great importance and published the popular magazine "Ruslan". These various and effective activities of the church, organized in particular by Metropolitan bishop Sylvester Sembratovych, were highly appreciated and praised by the Holy See. At the glorifying celebration of the 300th anniversary of the Union of Brest in Rome, Pope Leo XIII dedicated a speech to the Ukrainian Church and granted Metropolitan bishop S. Sembratovych the rank of a cardinal ${ }^{193}$.

The Greek Catholic Church reached the XX century with several significant achievements: the loss of leadership in the processes of political nation-building did not deprive it of the role of the ethnospiritual leader of the Catholics of the Eastern Rite in the regions of Galicia and Transcarpathia. The trials of previous centuries have demonstrated that the church and its parishes are ready to engage in liberation campaigns in order not only to gain national-cultural rights, but also to struggle for the statehood and unity of Ukraine.

\footnotetext{
192 Великий А. Г., ЧСВВ. 3 літопису християнської України. Т. VIII: XIX ст. Рим: Вид-во оо. Василіян, 1976. С. 245-248.

193 Пашук А. Українська церква і незалежність України. С. 222-223; Історія релігії в Україні. Т. 4. Католицизм. Київ, 2001. С. 353-371, 407.
} 


\section{PART 3. \\ CONTRIBUTION TO THE CONSOLIDATION \\ OF THE STATE-UNIFYING FORCES (FIRST DECADES OF THE XX CENTURY)}

During the first decade of the new century, Galician Ukrainians made considerable progress in all areas of social-political, economic and cultural-educational life. Overcoming the obstacles, which the Austrian authorities and the Polish administration had put in their way, the Ukrainian cooperative movement continued to develop. The development of the cooperative enterprises met the material needs of small producers, strengthened rural economy and laid the economic foundation for the national liberation movement ${ }^{194}$. It was the community "Vidrodzhennia" ("Renaissance"), founded in 1909 with the help of priests, which became the organizer of the anti-alcohol movement ${ }^{195}$.

There could be seen a considerable rise in the reputation of the Ruthenian Pedagogical Society while in between 1902-1910 it was headed by the Greek-Catholic priest Ivan Chapelsky (1858-1918) ${ }^{196}$. The Shevchenko Scientific Society in Lviv took care of national science and culture issues. It managed to unite the scientific and literary as well as artistic elite of Ukraine thanks to the leadership of such people as M. Hrushevsky, I. Franko, V. Hnatiuk ${ }^{197}$. It was in the printing house of this society where dozens of religious books appeared to meet their readers. Due to the efforts of the Galician community, particular its priests and clergymen, Ukrainian schooling developed greatly. Before the war, one could find 6 state and

\footnotetext{
${ }^{194}$ ЦДІАУЛ. Ф. 358. Оп. 1. Спр. 112, 125; Історія споживчої кооперації України. Львів, 1996. С. 103-109.

195 Савчук Б. Корчма: алкогольна політика і рух тверезості в Західній Україні у XIX - 30-х роках XX ст. Івано-Франківськ, 2001. С. 118-122.

196 Товариство «Рідна школа»: історія і сучасність. Науковий альманах. Ч. 1. Львів, 2001. С. 168-169.

197 Грицак Я. Нарис історії України. Формування модерної української нації XIX -XX століття. Київ, 1996. С. 207.
} 
15 private grammar schools as well as 3 thousand public schools and 7 Ukrainian departments in the Lviv University in the region ${ }^{198}$.

In the first third of the XX century the Metropolitan bishop of the Greek-Catholic Church could be called the central figure of Galicia. His name was Andrey Sheptytsky, and he received his church name Reverend Andrey on August 22, 1892 at the hands of the Bishop Yulian Pelesh. Soon afterwards, on June 22, 1896, he already had a rank of a Doctor of law and a novice master and was appointed an abbot of the Lviv monastery of St. Onuphrius, from where he exercised extensive missionary activity. The following year he was elected a secretary of the protohegumen of the Galician province of the Order of St. Basil, and on May 1, 1897 he together with Reverend Platonid Filias co-founded the first religious monthly magazine "Missionar" ("Missionary"), which was rightly called the Apostle of the Ukrainian People ${ }^{199}$. The founders of the magazine did not want to limit it only to religious subjects, they regularly wrote about moral, family and other aspects of secular life ${ }^{200}$. Later on, this magazine was in a full responsibility of the Metropolitan bishop Andrey Sheptytsky. Not only he assisted the editorial staff financially, but he also published the Pastoral Letters on its pages.

On February 2, 1899 Franz Josef appointed the 34-yearold Andrey Sheptytsky a bishop of the Stanislaviv Eparchy. He began his activities by attending parishes, during such visits he got familiar with the way of life of the peasantry, he taught and blessed people, helped the poor, and won the love and respect of the parishioners. On February 14-15, 1900 A. Sheptytsky visited the Ukrainian grammar school in Kolomyia and received a warm welcome from its pupils ${ }^{201}$. His first pastoral letter to the clergy and the Christ followers concerned urgent problems of the Ukrainian people and the clergy in particular - he urged people to live according to the Christian laws of

\footnotetext{
198 Полонська-Василенко Н. Історія України. Т. 2. Київ: Либідь, 1992. С. 434.

${ }^{199}$ ЦДІАУЛ. Ф. 358. Оп. 2. Спр. 4. Арк. 1-7; Слуга Божий Митрополит Андрей Шептицький. Календар 2004 р. / Упор. О. Гайова, відп. ред. о. Т. Янків. Львів, 2004. 26 c.

${ }^{200}$ Химка І.-П. Греко-католицька церква і національне відродження в Галичині 1772-1918. Ковчег. Львів, 1993. Ч. 3. С. 89.

${ }^{201}$ Ibid.C. 3-16.
} 
justice, to unite, to care for public education, to educate young people about their duties to society, to value independence and honest work $^{202}$.

The Greek Catholic clergy used to not only support but also to lead the national movement. This went on until the 90's of the XIX century. However, the radicalization of the national movement and the rise of anti-clericalism in the environment of social democracy and a part of the young intelligentsia were responsible for slowing down of the cleric national movement. Some representatives of the church also contributed to this process. In particular, the new bishop of Stanislaviv Hryhoriy Khomyshyn (who was appointed since June 19, 1904) and his supporters believed that the church should limit its interference into the liberation movement ${ }^{203}$.

37-year-old Bishop Hryhoriy Khomyshyn started his activity conducting meetings for the clergy, as well as visiting different parishes. He successfully preached and blessed people during these activities. He was rather functional in removing the Russophiles from the capitol, and he secured the allocation of government funds in order to open a seminary in Stanyslaviv (1907). On his initiative, there were purchased two squares in the city, on the first one there was built a luxurious building, which housed a hotel later (now it is "Dnister"), a cinema hall (now People's House No. 1), and private rented premises. In order to develop national capital, he became a co-sponsor of the Land Mortgage Bank ${ }^{204}$.

It was clear that at the beginning of the XX century Metropolitan bishop Andrey Sheptytsky opposed such ideas of Hryhoriy Khomyshyn. First of all, he considered them wrong, and then he had strong objections concerning indirect participation of clergymen in the national movement. Of course, in the new political

202 Сапеляк А. Київська церква на слов'янському Сході. Буенос-Айрес; Львів, 1999. C. $107-108$.

${ }^{203}$ ЦДІАУЛ. Ф. 164. Оп. 1. Спр. 163. Арк. 1 -40; Оп. 2. Спр. 204. Арк. 1-25.

204 Єгрешій О. Єпископ Григорій Хомишин і питання українсько-польського порозуміння 1904-1939 pp. Івано-Франківськ, 2001. 71 с.; Сгрешій О. Взаємовідносини митрополита Андрея Шептицького і єпископа Григорія Хомишина. Галичина. 2001. № 5-6. С. 315-321; Пелехатий І. Я згину в тюрмі, а ви мусите жити... . Нова зоря. 1997. 25 березня. 
situation, the church should have remained separated from the national movement, but it had to support it as long as it adhered to the Christian principles of morality. A. Sheptytsky emphasized that, while dealing with national affairs, no one had a right to break Christian ethics, because evil not only remained unhelpful to "the pure and holy case of the people, but also harmed it directly"205. That is why in the Pastoral Epistle of the Metropolitan bishop and Bishops to the People on the murder of the Galician governor, Polish Count Andrzej Potocki, by the Lviv student Myroslav Sichinsky in 1908 , this terrorist act was strongly condemned ${ }^{206}$.

Andrey Sheptytsky took the post of the Metropolitan bishop at a festive celebration on January 17, 1901 at St. George's Cathedral ${ }^{207}$. After this event, as many historians noted down, there started a new epoch in the history of the Greek Catholic Church. At that time the Greek Catholic Church had 1854 parishes and 2934 thousand of followers ${ }^{208}$. Metropolitan bishop A. Sheptytsky paid great attention to the problems of the clergy. He saw the low level of education of the parish priests as one of the reasons for the decline of church life at the turn of the century, and, therefore, sought to "shape the personality of the newest Ukrainian priest.., to nurture the Ukrainian clergyman capable of fulfilling the great mission of the Ukrainian Church"209. With this aim, he started building seminaries: in 1901 he reorganized the Lviv Seminary; students of this seminary attended lectures at the University of Lviv before the founding of the Theological Academy in 1928 by the Metropolitan bishop; in

\footnotetext{
205 Филипович Л. Митрополит Андрей (Шептицький) i Іларіон (Огієнко): проблема національної церкви. Церква і соціальні проблеми. Енцикліка «Сотий рік». Львів, 1993. С. 189.

${ }^{206}$ Спільне Пастирське послання митр. Андрея Шептицького та ін. єпископів до народу 3 приводу вбивства ц.-к. Намісника А. Потоцького 3 долученою інструкцією до духовенства. Митрополит Андрей Шептицький: Життя $i$ Діяльність. Документи і матеріали 1899-1944. Церква і суспільне питання. Т. ІІ. Кн. 1. Львів: Місіонер, 1998. С. 424.

207 Гайова О. Митрополит Галицький. Украйнський альманах 2001. Варшава, 2001. С. 99-103; ЦДІАУЛ. Ф. 358, оп. 2, спр. 4, 10.

208 Химка Іван-Павло. Греко-католицька церква в Галичині в 1772-1918 роках. Третій міжнародний конгрес украӥністів. Історія. Ч. І. Харків, 1996. С. 216.

209 Сапеляк А. Київська церква на слов'янському Сході. Буенос-Айрес; Львів, 1999. C. 111.
} 
1906 he established a seminary in Przemysl, and the following year there was created the Stanislaviv Theological Seminary.

Much work was done for the organizational development of the church. It is worth mentioning that in 1908 Pope Pius X extended the canonical powers of Metropolitan bishop A. Sheptytsky. In addition to the previous Galician Lviv, Przemysl and Stanislaviv eparchies A. Sheptytsky got under his control the Greek Catholic eparchies of the rest of Ukraine, Belarus, and Russia. That is, he received patriarchal authority with the right to appoint bishops on the vast territories of the east of Ukraine and beyond that. The head of the Ukrainian Church made a lot of efforts to bring Ukraine and Russia together in the light of the church union. He considered it his sacred task to provide church unification on the basis of the Union of Brest. At the end of 1886 he went to Moscow, where he visited the Trinity Lavra of St. Sergius. In November 1887 A. Sheptytsky visited Kyiv for the first time. On February 22, 1908 he had a private meeting with Pope Pius X discussing the authority of Catholic priests of the Eastern Rite in the Russian Empire. In October 1908 he secretly went to Ukraine again, he also visited Belarus, Lithuania, and Russia, laying the foundations of communities of Catholics of the Eastern Rite in St. Petersburg and Moscow ${ }^{210}$.

The very fact that a Ukrainian Metropolitan bishop of Galicia was granted the status of patriarch by the Apostolic Capital significantly strengthened the church and weakened the position of Polish Latinism in Galicia. It also meant that the city of Lviv received a new status and was considered as a stronghold of Kyiv Catholic Orthodoxy. Therefore, the role of church in national and cultural progress was still quite important. Led by Metropolitan bishop Andrey Sheptytsky, Galician clergy made a significant contribution while trying to solve the deep-rooted but topical problems, especially in the development of public schools. The clergy collaborated with the so-called "Ridna shkola" ("Native School"). On June 20, 1909 A. Sheptytsky blessed the educational institution of the Ruthenian Pedagogical Society. With the active involvement of the church representatives, there

210 ЦДІАУЛ. Ф. 358. Оп. 2. Спр. 4. Арк. 1-7; Оп. 2. Спр. 4. Арк. 1-2; Оп. 3p. Спр. 113. Арк.1-50; Слуга Божий Митрополит Андрей Шептицький. Календар 2004 р. / Упор. О. Гайова, відп. ред. о. Т. Янків. Львів, 2004. С. 2-24. 
happened considerable progress in the development of culture, especially in the rural areas. During the period from 1900 to 1914, Galicia opened 2,000 new reading rooms, 430 "Prosvita" houses and People's Houses (organizations which dealt with education and informing people of current political, social and economic issues, as well as provided them with literature and place for meetings and debate). All in all, there were 2,664 libraries and 2,944 reading rooms in operation all over the region, and they were headed mostly by priests ${ }^{211}$. The Greek Catholic Church supported large-scale public actions in order to establish a Ukrainian university. As a Metropolitan bishop, an Ambassador to the Galician Diet and the Austrian Chamber of Lords (since 1903) Andrey Sheptytsky made a report on the necessity of a Ukrainian university at the 22nd session of the Parliament on June $28,1910^{212}$. It was in 1913 , when there finally was received a permission to establish a university.

It is worth mentioning that the church and the Metropolitan bishop himself contributed to a large scale of the progress of national culture and art. Famous Galician politician Longyn Tsehelsky noted down that Metropolitan bishop A. Sheptytsky was involved in the creation or financing of the following institutions: the National Museum, the People's Hospital, the Maternity Council, an Orphanage, Dyakiv educational institution, the Theological Academy, the Women's Grammar School of the Sisterhood of the St. Basil Order, "Ridna shkola" school, an art studio, Hrinchenko School, Prince Lev school and others ${ }^{213}$.

Metropolitan bishop A. Sheptytsky took great care of the preservation and development of the cultural and artistic heritage in the region, the development of museums, book printing, church construction by common people. The Church Museum, founded in

\footnotetext{
211 ЦДІАУЛ. Ф. 358. Оп. 2. Спр. 118, 119; Герасимович I., Терлецький О. Шкільництво в Галичині в другій пол. XIX і на поч. XX ст. Енцииклопедія українознавства. Загальна частина. Т. 3. Мюнхен ; Нью-Йорк, 1949. С. 928-931; Rzemieniuk F. Unici Polscy 1596-1946. Siedlce, 1998. S. 139.

212 Промова митрополита гр. А. Шептицького в парламенті вельмож 28 червня 1910 р. Руслан. 1910. Ч. 134; Слуга Божий Митрополит Андрей Шептицький. Календар 2004 р. / Упор. О. Гайова, відп. ред. о. Т. Янків. Львів, 2004. С. 2-24.

213 Цегельський Л. Митрополит Андрей Шептицький. Львів: Місіонер, 1995. C. 46-47.
} 
December 1905 in Lviv by Metropolitan bishop Andrey Sheptytsky, was first housed in the ancillary premises of the Cathedral of St. George Cathedral, and since 1911 it was located in the representative palace (the current address is Drahomanov St., 42), which was also purchased by its founder. At the same time, the Metropolitan bishop provided the financial support to all his projects. In particular there was an annual sum of 18,000 crowns (3,600 USD) appointed for maintenance of the museum and, in particular, a unique collection of Carpathian icons (which included works by Ivan Rutkovych and Iov Kondzelevych). A lot of promising and famous scientists and culture activists as well as art appraisers were closely connected to the museum and took interest in its activity, it was the centre for meetings ${ }^{214}$. Until 1939 it housed 80,000 exhibits and a unique library (it contained 30,000 volumes of old printed books, books and albums), the museum managed to organize 70 exhibitions and published 16 volumes of scientific notes ${ }^{215}$.

As a result of the efforts by Metropolitan bishop and the Galician hierarchy, on the eve of the First World War, the Greek Catholic Church was the national-spiritual stronghold of the Ukrainian lands. Its organizational status in June 1914 was as follows ${ }^{216}$ :

\begin{tabular}{|c|c|c|c|c|c|}
\hline $\begin{array}{c}\text { Eparchies } \\
\text { (dioceses) }\end{array}$ & deaneries & parishes & churches & priests & $\begin{array}{c}\text { church } \\
\text { followers }\end{array}$ \\
\hline $\begin{array}{c}\text { Lviv } \\
\text { Przemysl }\end{array}$ & 53 & 754 & 1308 & 886 & 1335977 \\
Stanislaviv & 21 & 629 & 1320 & 826 & 1252492 \\
\hline Total & 115 & 1816 & 3224 & 2250 & 3610469 \\
\hline
\end{tabular}

The monastic life was in its prime time during that period. Prominent place in it was occupied by the Order of St. Basil the Great and Metropolitan bishop A. Sheptytsky constantly took care of it. Before the outbreak of World War I, this order had 16 monasteries

\footnotetext{
214 Літопис Національного музею у Львові. 2000. № 1 (6). С. 5-10, 43.

215 ЦДІАУЛ. Ф. 358. Оп. 2. Спр. 122. Арк. 1-20; Митрополит Андрей Шептицький. Матеріали та документи (1865-1944). 2-ге видання. За ред. Заборовського Я. Ю. Львів; Івано-Франківськ, 1995. С. 21.

${ }^{216}$ Rzemieniuk F. Unici Polscy 1596-1946. Siedlce, 1998. S. 149.
} 
on the territory of the land as well as two overseas missions, that amounted to the staff of two hierarchs, 85 priest monks, 77 members of the brotherhood, 47 students, i.e. a total of 211 monks and 23 novices $^{217}$. In order to strengthen missionary work and to improve the theoretical level of priests training, Metropolitan bishop revived the ancient Order of Students and personally developed a new monastic charter in 1903. Klymentiy Sheptytsky, who was the brother of Metropolitan bishop, headed the Order. In addition, in August 1913, the head of the church invited priests of the Belgian Order of the Redemptorists, who accepted the Eastern rite, to take part in the missionary work in Galicia, Volyn, Podlachia and Polesia ${ }^{218}$.

Metropolitan bishop Andrey Sheptytsky was clearly concerned about the problem of national and political consolidation of Ukrainians. He did not make any controversial statements concerning one or the other side of the conflict, as he did not want to bring political discord into the church environment. However, it seemed that he sympathizes strongly to the Ukrainian National Democratic Party. Andrey Sheptytsky went so far that he even participated in the meetings of the UNDP's Wide People's Committee, offering mediation in the settlement of the discord between the Ukrainian ambassadors to the Austrian State Council from Galicia and Bukovina. Due to his mediation there were conducted some PolishUkrainian negotiations in the first half of 1914 and they concerned the issue of implementation of the Diet electoral reform ${ }^{219}$.

Despite the formally proclaimed equality of all Catholics of the Austro-Hungarian Empire, the Greek Catholic Church, compared to the Latin one, was in a worse position because it was a spiritual representative of a nation that had deprived of its national state, elite or even self-understanding for centuries. Therefore, the struggle for the equalization of rights with the Latin clergy was an important

\footnotetext{
217 Ваврик М., ЧСВВ. Нарис розвитку і стану Василіанського Чина. XVII ХХ ст. Рим, 1979. С. 65.

218 Слуга Божий Митрополит Андрей Шептицький. Календар 2004 р. / Упор. О. Гайова, відп. ред. о. Т. Янків. Львів, 2004. С. 17.

219 ЦДІАУЛ. Ф. 358. Оп. 1. Спр. 74. Арк. 1-2; Расевич В. Митрополит Андрей (Шептицький) і проблема національно-політичної консолідації українців (19001918 роки). Ковчег. Ч. 2. Львів, 2000. С. 212-223.
} 
component of the liberation movement of Western Ukrainians, and Greek Catholic priests took the lead in the process of forming their leadership and ideology in the first half of the nineteenth century.

World War I, which began on August 1, 1914, became a turning point in the formation of the self-defining ideas, on the basis of which the Ukrainian liberation movement unfolded in both the AustrianHungarian Empire and the Russian Empire. The ideas of state independence and unity penetrated into the national consciousness of Ukrainians deeply, therefore they formed the basis of future programs of action for various political organizations.

Western Ukrainians were quicker to fully assess and apprehend the difficult geopolitical situation, created by the War. Consequently, they made an attempt to use interstate contradictions in order to achieve their own national aspirations. On August 1, 1914, there was created the Supreme Ukrainian Council in Lviv. It was a cross-party political leadership of the Galicia region. In order to implement its state and political intentions, the Council formed the Ukrainian Military Administration, which began the formation of the Ukrainian army, with the official permission from Vienna ${ }^{220}$. At the same period, emigrants from the Dnieper region founded the non-partisan Union of Liberation of Ukraine in Lviv, which proclaimed a program of struggle for an independent Ukrainian state, and the implementation of this idea was closely connected with the military defeat of imperial Russia ${ }^{221}$.

The Greek Catholic Church supported national and political forces since the outbreak of the War. It fully agreed with the prospect of creation of an independent unified Ukraine, which had to be formed on the ruins of the Russian Empire. In a special memorandum to the Austrian government "On the future military legal and ecclesiastical system of the Russian Ukraine in anticipation of its occupation by Austrian troops" from August 15, 1914, Metropolitan bishop Andrey Sheptytsky outlined a plan to solve the Ukrainian problem after Austrian troops would enter the territories of Ukraine, which had been under the Russian rule. Metropolitan bishop intended to separate the Ukrainian church from the Russian church influence, from the

220 Литвин М., Науменко К. Історія галицького стрілецтва. Львів, 1990.

221 Патер І. Г. Союз визволення України. Львів, 2000. 
power of St. Petersburg Synod. There was also a proposal to bring back to life the Hetman institution, while the Austrian laws were still to be introduced (taking into account the territorial proportions). This would make Ukraine a full-scale member of the legal system of Europe $^{222}$. The outlined plan of reorganization of the Ukrainian Orthodox Church did not affect the canonical bases of either the Orthodox or Catholic Churches, but it would put the former in the rank of self-governing, autocephalous churches. Unfortunately, socialists from the Dnieper region ignored this state-building plan. It is worth mentioning that this memorial was discovered by the Russian police and presented to Tsar Nicholas the Second by Sturmerg, who was the Minister of Internal Affairs, on July 27, 1916. The Tsar (Emperor) wrote with his own hand on it: "What a scoundrel!"223. On August 21, 1914, Metropolitan bishop Andrey Sheptytsky addressed the clergy and the church followers with a Pastoral letter, in which he noted that Russia's goal was to capture Galicia and stifle the Ukrainian national movement ${ }^{224}$.

The Greek Catholic Church was loyal to official Vienna and the leadership of the church found themselves in a difficult situation in those days because of the mass repression of the Polish-Austrian authorities against the Ukrainian population of the region. Under the pretext of fighting against Moscowphiles, tens of thousands of Ukrainians were deported to the concentration camps of Thalerhof, Gmünd, Theresienstadt, and Esztergom. In general, from the 6,000 Ukrainians, who were arrested and taken to Thalerhof,

\footnotetext{
222 Меморандум митр. А. ІІІептицького «Про церковну організацію». Церква і церковна єдність. Документи і матеріали. Т. 1. Львів: Свічадо, 1995. C. 130-131.

223 Гайковський М. Сучасне і майбутнє України: думки і візії митрополита Андрея Шептицького. Київська иерква. 2000. № 1. С. 43-46; Донесення працівника МВС Росії Штюрмерга. Церква і иерковна єдність. С. 133.

${ }^{224}$ Мазур О., Патер І. Львів у роки Першої світової війни. Львів. Історичні нариси. Львів, 1996. С. 306. Байса Г. Монахи Студитського уставу. Постуn. 2000. 22 січня.
} 
1767 died. The Sknyliv Lavra of students in Lviv was completely destroyed ${ }^{225}$.

During the first days of the war, a large-scale battle for Galicia broke out on the Carpathian territories. On September 3, 1914, Russian troops of the Southwestern Front occupied the city of Lviv and they brought on serious losses to the Austrian-Hungarian forces. Later on, they reached the San River and took under siege the mighty fortress of Przemysl, and thus they occupied almost all of the Carpathian region ${ }^{226}$.

The new authority of the occupation regime launched a large-scale campaign against the political and social activists of the region. Governor-General O. Bobrynsky issued a decree "on the prohibition of the functioning of various clubs, unions and societies and the temporary closure of educational establishments, boarding schools and courses existing in Galicia, with the exception of educational workshops". Therefore, Ukrainian societies, publishing houses, newspapers, and schools were closed ${ }^{227}$.

The Russian occupational authority sought to neutralize and, if possible, eliminate the Greek Catholic Church as well as convert its followers into the Russian Orthodoxy. Representatives of the united church (i.e. Greek-Catholicism) were regarded as the spiritual pillar of Ukrainian separatism ${ }^{228}$. The program of activities of the Russian administration in the field of church policy, prepared by The St. Petersburg "Galician-Ruthenian Charitable Society" prepared the whole program, activities of which were supposed to influence directly the church policy under the Russian administration. The specific proposals outlined there included the following ones: to give to the Orthodox clergy all the churches on the territories, where the majority of people would reject Greek-Catholicism; to shut down Jesuit and Basilian orders; to get rid of Metropolitan bishop Andrey

\footnotetext{
225 Талергофський альманах. Львів, 1935. Вип. 3. С. 138; Кугутяк М. Пам’яті жертв трагічних подій у Перемишлі і Синевідську восени 1914 року. Галичина. 2003. № 9. С. 134-144.

${ }^{226}$ Нагаєвський І. Історія Української держави ХХ ст. Київ, 1993. С. 56.

${ }^{227}$ Грушевський М. Ілюстрована історія України. Нью-Йорк, 1990. С. 527.

228 Великий А.Г., ЧСВВ. Світло і тіні української історії. Причинки до історії української церковної думки. Рим: вид. оо. Василіян: 1969. С. 34.
} 
Sheptytsky and Bishop Hryhoriy Khomyshyn ${ }^{229}$. In order to implement plans to convert Greek Catholics into Orthodoxy, there arrived 200 Orthodox priests, they were headed by Archbishop of Volyn Yevlohiy (Heorhievsky) ${ }^{230}$.

Still, Metropolitan bishop Andrey Sheptytsky stood in the way of denationalization of the church, as he was trying to minimize the success of Russian politicians. Their intentions were to launch a great spiritual expansion, and they had been preparing for this for decades, while they had been supporting the Galician Moscowphiles financially ${ }^{231}$. On September 6, 1914, in the Dormition Church, the Metropolitan bishop delivered a speech after a sermon in which he described the tragedy of the war, and he urged the Lviv inhabitants to defend their faith from the Moscow attacks ${ }^{232}$. Metropolitan bishop was consequently arrested on September 18 and on September 19, 1914, he was taken to Russia, mainly because of this evidently antiRussian speech. After being taken to the Monastery of St. Euthymius in Suzdal on September 17, 1916, Andrey Sheptytskyy stayed there until the February Revolution of 1917. Shortly after the deportation of Metropolitan bishop, there were arrested and exiled more people, including bishops Yo. Botsyan and D. Yaremko (died in 1916), prorector of Stanislaviv theological seminary Ye. Lomnytsky (died in exile in 1915) and more than fifty priests of the region ${ }^{233}$. Still, bishops Evlogii and Antoniy (who had arrived from Kharkiv) found it really difficult to convert Greek-Catholics into the Russian Orthodoxy ${ }^{234}$. During the ten months of the Russian occupation, they

\footnotetext{
${ }^{229}$ Ibid. C. 35.

${ }^{230}$ Мазур О., Патер І. Львів у роки Першої світової війни. Львів. Історичні нариси. Львів, 1996. С. 312; ЦДІАУЛ. Ф. 408, оп. 1, спр. 684, арк. 2-88.

231 Москвофільство: документи і матеріали / Вступна стаття, коментарі і матеріали О. Сухого; заг. ред. С. Макарчука. Львів, 2001. 236 с.; Сухий О. Від русофільства до москвофільства. Російський чинник у громадській думці та суспільно-політичному житті галицьких українців у XIX столітті. Львів, 2003. C. $176-372$.

232 Проповідь митр. Шептицького. Церква і иерковна єдність. Документи i матеріали. Т. 1. Львів: Свічадо, 1995. С. 132-133.

233 Вивезене росіянами українське духовенство. Нива. Львів, 1916. Цвітень. Ч. 4. С. 262-264.

${ }^{234}$ Великий А.Г., ЧСВВ. Світло і тіні української історії. Причинки до історії української церковної думки. Рим: вид. оо. Василіян: 1969. С. 36.
} 
were only 81 out of the 1784 Greek-Catholic parishes that had fully or partially converted to Orthodoxy, and that amounted to four percent $^{235}$.

On the eve of the Russian occupation, one of the proto-abbots of the province called Platon Filias evacuated most of the monks to the west, namely to Croatia, Moravia and Austria. Afterwards the Holy See appointed him the Apostolic Administrator for Ukrainian Catholics who were exiled or deprived of their homeland because of the military conflict ${ }^{236}$. The proto-hegumen succeeded in placing the Galician monks of the Order of St. Basil in Croatian monasteries, he managed to release Ukrainian priests from the Austrian concentration camps of Thalerhof, Gmund and Dabie, he also succeeded in gathering of the 75 dispersed students of spiritual seminaries, and establishing a Basilian religious seminary for them in the Moravian city of Kromeriz. Reverend Yosafat Kotsylovsky became its rector. $\mathrm{He}$ also managed to reopen the publication of the "Missionary" in Zagreb.

In the first days of the war, the proto-hegumen gathered 62 monks and placed them in the Krekhiv Monastery, which was situated in the mountain corner of Lviv's Roztochia. However, by the end of 1914 there remained only seven monks, while majority of them was mobilized to the Austrian-Hungarian army, some went to the West, and some were deported by Russians ${ }^{237}$.

While the new regime was preparing for the visit of Nikolai II, they carried out brutal limiting actions against the so-called "mazepyntsi" (i.e. people who had Ukrainian nationality and were eager to defend their national rights) in Przemysl and nearby villages. Bishop Konstiantyn Chekhovych of Przemysl passed away, after being seriously pressured by Russian officers, who demanded a conversion to the Orthodox rite and even sealed a part of the Episcopal Chamber on April 15, 1915. At the same, the corresponding member of the Russian Academy of Sciences Ye. Shrumylo sent to Petrograd the Przemysl crown of Daniel of

\footnotetext{
${ }^{235}$ Ibid.C. 36-37.

236 Назарко І. Київські і галицькі митрополити. Торонто: Вид-во ОО. Василіян, 1962. C. 174.

${ }^{237}$ Мiсiонар. Ч. 3.1920. С. 56-58.
} 
Galicia and the flag of the Przemysl "Sokil"; this was done on the pretext of the possible destruction of the city, allegedly to preserve the ancient artifacts from being lost forever.

All the negative actions of the new regime, which included destruction of Ukrainian cultural and educational institutions, persecution of Catholics of the Eastern rite, and the forcible conversion of them to Orthodoxy, as well as repressions and deportation actions (over 12,000 people were taken to Siberia alone, though they first had to go through Kyiv prisons), provoked protest of the local Christian public. The Supreme Ukrainian Council, Ukrainian Parliamentary Representation, the Union of Liberation of Ukraine informed European society about violent actions of Russian occupying power, and their gross violation of international law ${ }^{238}$. A. Sheptytsky was well informed about the foundation of the Union of Liberation of Ukraine (which took place on August 4, 1914) and he promised to help and support this organization ${ }^{239}$. Occupation policy of Russia in Galicia was condemned even by well-known Russian state and church figures, including the State Duma deputies P. Miliukov, O. Kerensky, writer V. Korolenko, and Krasnoyarsk bishop Nikon ${ }^{240}$.

It is well-known that the Russian army left the fortress of Przemysl, Lviv and almost all of Galicia as the result of the Gorlice offensive operation of the Austro-German troops in May-June $1915^{241}$. Immediately after the territory was freed, the activity of Ukrainian institutions, especially public-political organizations, publishing houses, cooperatives, scientific and educational institutions resumed.

The Greek Catholic Church, which was headed by Stanislaviv Bishop Hryhoriy Khomyshyn after the deportation of A. Sheptytsky, started to gradually get rid of the negative results of the Russian rule.

\footnotetext{
238 Патер I. Перемишль і Перемищина під час російської окупації у березнічервні 1915 року (за матеріалами ЦДІА України у Львові). Перемишль і Перемиська земля протягом віків. Перемишль; Львів, 1996. С. 166-167.

239 Литвин В. Україна: доба війн і революцій (1914-1920). Київ, 2003. С. 46-47.

240 Федорів Ю. Історія церкви в Україні. Торонто, 1967. С. 350; Русские ведомости. Москва, 1916. 11 сентября.

241 Мазур О., Патер І. Львів у роки Першої світової війни. Львів. Історичні нариси. Львів, 1996. С. 315.
} 
The main problem was the huge lack of priests. According to the calculations of the Polish historian of the United Church (GreekCatholic), F. Rzhemenyuk, a lot of priests irrevocably lost their parishes in the course of the Russian occupation of Galicia, among the 2483 active Greek Catholic priests 350 ones were interned by the Austrian authorities, 350 moved to the Western countries just before the Russians came, 61 people left for Russia, and 120 either converted to Orthodoxy or collaborated with Orthodox structures. As the result, there were 1572 priests and clergy representatives left ${ }^{242}$. It is worth mentioning that several dozen priests as chaplains were part of the front Ukrainian regiments and the Legion of Ukrainian Sich Riflemen.

As it was already noted down, the newest era of national liberation was started by the legion of the Ukrainian Sich Riflemen. The Greek Catholic Church made a significant contribution to the formation of national-patriotic feelings and the high morale of the riflemen and their commanders. The Greek Catholic Church took care of the legion and their spiritual life from the first days of its existence. In the ranks of the army, there were active the following field priests: Reverend A. Przepiursky, M. Yizhak, Yu. Fatsievych, and Reverend P. Bodnar who was working in the hospital. Metropolitan bishop Andrey Sheptytsky visited the regiments of the Legion of the Ukrainian Sich Riflemen called "Kish" and "Vyshkil" on October 27-28, 1917, which were stationed in the village Rozvydiv in the Lviv region. There he blessed the flag of the Ukrainian Sich Riflemen, which was embroidered with the emblems of Kyiv and Galicia ${ }^{243}$.

Only in 1915, Greek Catholic chaplains created 226 field chapels on the front. They went on with their missionary work and their efforts brought results. The religious magazine "Missionary" was much popular among the soldiers, as it published messages from the hierarchs of the church, articles of spiritual and intellectual content, as well as world and regional messages, in particular, about the founding of the orphanage in Lviv under the name "Ukrainian Orphans Protection" or about the release of disabled military

\footnotetext{
${ }^{242}$ Rzemieniuk F. Unici Polscy 1596-1946. Siedlce, 1998. S. 143-144, 151-152.

243 Якимович Б. Збройні Сили України. Нарис історії. Львів: Інститут українознавства НАНУ, 1996. С. 84; ЦДІАУЛ. Ф. 408. Оп. 1. Спр. 566. Арк. 1-3.
} 
prisoners from the Russian captivity, which had been possible due to the interference of Pope Benedict XV ${ }^{244}$.

The release of Andrey Sheptytsky from exile in March 1917 gave a powerful boost to the national and organizational strengthening of the church. Just after his release, Metropolitan bishop arrived in the city of Petrograd to meet with O. Kerensky, P. Miliukov, as well as members of the Ukrainian National Council to clarify the political, religious, and church-relevant situation after the fall of the tsar and change of the rule. He managed to achieve an official recognition of the Greek Catholic Church and get the same rights for it comparing to the Catholic Church in Russia as a result of his meeting with G. Lvov, the Head of the Russian Provisional Government. At the end of April in 1917, in Kyiv, he held negotiations with the leaders of the Central Council, M. Hrushevsky and S. Rusova, on the problems of the church and national-state prospects. This visit of Metropolitan bishop brought back to life the issue of the Greek Catholic Church and its activity under the rule of the Ukrainian People's Republic, as well as the issue of its contribution into the liberation process.

It should be noted that the religious and ecclesiastical activities of Metropolitan bishop were constantly directed at the expansion of the sphere of influence of the Greek Catholic Church in Russia, as there were hundreds of thousands of displaced people and prisoners of war from Galicia. This activity had to lay the foundation for unification of the churches of the West and the East. The ideas of ecumenism became the basis of his work in the city of Petrograd, where on May 19-31, 1917, he held the synod of the Russian Greek Catholic Church and during this synod Leonid Fedorov, the monk-student, was granted the title of the exarch. At the same time, Metropolitan bishop managed to establish a Catholic Apostolic Vicariate for all Ukraine in Kyiv, it was headed by Reverend Mykhailo Tsehelsky.

After his unsuccessful attempt to get to Rome bypassing the front lines, Metropolitan bishop Andrey Sheptytsky returned to Lviv on September 10, 1917, where he was greeted by the parishioners. Metropolitan bishop continued his work as a spiritual leader, and in his Pastoral Letters, which resumed to be published

${ }^{244}$ Місіонар. 1918. Ч. 5. С. 67-68; ЦДІАУЛ. Ф. 408. Оп. 1. Спр. 321. Арк. 2-30. 
after his return, he addressed the clergy and urge them to work even more selflessly in order to restore the church structures destroyed by war, he also talked about the necessity of national upbringing and the need to nurture a feeling of patriotism, love for the people of the native land and their mother tongue ${ }^{245}$.

A. Sheptytsky openly revealed his national and state positions by the fact that he manifested his support of the Treaty of Brest-Litovsk from 9 February 1918. Later he manifested the right for national selfdefining of Ukrainians is the speech from 28 February 1918, which he delivered in the city of Vienna in the Chamber of Ambassadors while he was defending the right of peoples to their own political state. A. Sheptytsky thanked the Austrian Government for understanding of Ukrainian aspirations, and then he supported Eastern Galicia in its wish to become independent ${ }^{246}$. As well as the rest of Ukrainian ambassadors, he wanted the Austrian Parliament to ratify the Treaty of Brest-Litovsk and recognize the separation of Ukrainian lands from the Polish lands as well as granting them (i.e. Ukrainians) national and cultural autonomy. After official Vienna had ignored the demands of Ukrainians, Metropolitan bishop supported a parliamentary representation with the idea to convene a representative constitutional assembly in Lviv, as it was supposed to make decision on the political prospects of the Ukrainian lands within the Habsburg multi-ethnic empire.

In the autumn of 1918, powerful national liberation movements destroyed the Austrian-Hungarian Empire from within, and its fragments became the following independent states: Poland, Hungary, Czechoslovakia, Yugoslavia. On October 18-19, a representative assembly of about 500 Ukrainian political and religious figures was held in Lviv, and they managed to elect the Ukrainian National

245 ЦДІАУЛ. Ф. 408. Оп. 1. Спр. 572. Арк. 1; Місіонар. 1918. Ч. 5. С. 68; Ульяновський В. Церква в Українській державі 1917-1920рр. (доба Української Центральної Ради). Київ: Либідь, 1997. С. 85-89; Дорошенко Д. Арест и ссылка митрополита А. Шептицкого. На чужой стороне. Прага, 1925. Вып. ХІІ. С. 160-166; Лотоцький О. Сторінки минулого. Т. 3. С. 376-379; Грушевський М. Спомини. Київ. 1989. № 9. С. 131; Шевців Іван, о. Збірник. Статті, доповіді, промови. Львів: «Свічадо», 1996. С. 67.

246 Красівський О. За українську державу i церкву. Львів: Інститут українознавства ім. І. Крип'якевича НАНУ, 1995. С. 8-9. 
Council and proclaim the revival of an independent Ukrainian state on the Ukrainian ethnic lands of the former Austrian-Hungarian state. A massive rally on the square near the St. George's Cathedral in Lviv was held on October 20, and it unanimously approved the proclamation of the sovereignty of the Ukrainian lands ${ }^{247}$. The Greek Catholic Church strongly supported the state-forming decrees of the assembly. Metropolitan bishop A. Sheptytsky, bishops H. Khomyshyn and Yo. Kotsylovsky, as well as nearly two dozen priests were elected to the National Council and became active participants of its legislative process.

The Greek Catholic clergy welcomed the proclamation of the independent Ukrainian People's Republic in January 1918, they took an active part in the November National Democratic Revolution of 1918 and development of the West Ukrainian People's Republic, the latter one was created by the Provisional Basic Law from November 13, $1918^{248}$.

Pope Benedict XV followed the national-democratic revolutions in Central and Eastern Europe closely. It was at the beginning of November 1918, when he ordered the Nuncio to Vienna to form "friendly relations with the various nations of the former AustrianHungarian Empire that managed to create independent states" ${ }^{249}$. In general, the state building process of the young republic had a rapid pace. On November 9, 1918, there was formed a government and Oleksandr Barvinsky was appointed the state secretary of religious issues. In accordance with the Provisional Basic Laws of the Western Ukrainian People's Republic, county commissioners, who were chosen form the county National councils, became the local authority. It is worth mentioning that many priests were members of the county National councils ${ }^{250}$.

\footnotetext{
247 Західно-Українська Народна Республіка. 1918-1923. Т. 1. Івано-Франківськ, 2001. С. 184-203; Литвин М., Науменко К. Історія ЗУНР. Львів: Інститут українознавства ім. І. Крип'якевича НАНУ, 1995. С. 28-29.

248 Лебедович І. Полеві духовники Української Галицької Армії. Вінніпег, 1963. C. 31 .

249 Хома І. Апостольський престіл і Україна 1919-1922. Рим, 1987. С. 6-7.

250 Лужницький Г. Українська церква між Сходом і Заходом. Філадельфія: Провідіння, 1954. С. 544; Павлишин О. Організація цивільної влади ЗУНР 
During the first half of November 1918, Greek-Catholic priests became a part of the local executive and representative bodies of the Ukrainian administration. There was a fair share of clergy in county councils as well. In particular, there were four priests in the Kosiv district council, which consisted of 25 members in total, and out of five members of the Radekhiv council there were 2 priests. It is also worth mentioning that one in seven members of the National Council of the Western Ukrainian People's Republic was also a priest (that amounts to $14 \%)^{251}$.

There was also a great involvement of priests in party and political activity. In particular, many priests shared the state-political views of the ruling Ukrainian National Democratic Party, therefore there were 20 priests among the 139 delegates at an extraordinary congress of the party on March 28-29, 1919, in Stanislaviv. That Congress declared that the state was in need of freedom of conscience and religion, equality of religious denominations and their internal selfgovernment ${ }^{252}$.

That is no secret that A. Sheptytsky had a great reputation and influence in Ukraine (the so-called Great Ukraine). The Directorate of the Ukrainian People's Republic was interested not only in the unification of the Ukrainian People's Republic and the West Ukrainian People's Republic, but they also discussed the project of forming a new Kyiv Patriarchate, which, according to V. Vynnychenko, could have been headed by A. Sheptytsky. In fact, on December 19, 1918 the Foreign Minister of the West Ukrainian People's Republic Longyn Tsehelsky met the head of the Directorate of the Ukrainian People's Republic in Kyiv, and they discussed the

у повітах Галичини (листопад-грудень 1918 року). Украӥна модерна. Львів, 1999. Число 2-3. С. 132-193.

251 Павлишин О. Соціально-політичний портрет українського проводу Галичини та Буковини в революції 1918-1919 років. Україна модерна. Вип. 4-5. Львів, 2000. С. 187-245; Західно-Українська Народна Республіка. 1918-1923. T. 1. C. 286-366, 410-411, 466-516, 445-550.

252 Кугутяк М. Історія української націонал-демократії 1918-1929. Т. 1. С. 120-122; Т. 2. С. 105-116; Нагаєвський І. Історія Української держави двадцятого століття. Київ: Український письменник, 1993. С. 381. 
fate and place of the Metropolitan bishop of Galicia, who had been practically held captive by Poles in the St. George Cathedral ${ }^{253}$.

Despite the fact that after Lviv had been captured on November 22-23, 1918, Andrey Sheptytsky was confined to his Metropolitan Chamber (in fact, he was held captive there); he continued to defend the interests of the West Ukrainian People's Republic and the church. It was on his behalf that Bishop of Stanislav Hryhoriy Khomyshyn addressed the church followers with a Pastoral Letter from Metropolitan bishop. That letter urged all priests to pray in their sermons and Holy Liturgies for the President of the National Council of the West Ukrainian People's Republic Yevhen Petrushevych, for the Ukrainian state, its government and the Galician $\operatorname{army}^{254}$. The Metropolitan bishop refused to maintain any relations with the Occupation Administration of Lviv, and soon afterwards, he refused from collaboration with Jozef Bilczewski, the Archbishop of Latin Rite, because of the latter's chauvinism and support of militaristic actions in the country ${ }^{255}$.

Dozens of patriotic priests joined the Galician Army, its combat groups and district military crews either as volunteers or by the invitation from the army commanders; they became field priests (chaplains). Other priests voluntarily served on the battlefields or at different institutions, primarily in hospitals. Field priests of the Galicia Army adopted and enhanced the traditions of chaplains of the Legion of Ukrainian Sich Riflemen and Ukrainian regiments of the World War period ${ }^{256}$.

It should be emphasized that it was only the Galician army, which introduced the institute of field priests in its structure, the only one of all military formations during the liberation events of Ukraine from 1914 to 1923. It also should be noted that its contemporaries

253 Цегельський Л. Від легенд до правди. Львів, 2003. С. 181-186; Володимир Винниченко та ідея українського патріархату. Нова Зоря. 1993. Жовтень. Ч. 35-36.

254 Цвенгрош Густав. Національно-державницькі погляди митрополита Андрія Шептицького й польсько-українська війна 1918-1919 pp. Україна-Польща: Історична спадщина й суспільна свідомість. Матеріали конференції. Київ: Либідь, 1993. С. 178.

255 Футулуйчук В. Служба преподобництва УГА. Українські варіанти. 1999. № 1-2. С. 70-73.

256 Литвин М. Українсько-польська війна 1918-1919 рр. Львів, 1998. С. 188-189. 
considered the Galician army to be the most efficient one in terms of fighting. Its personnel had distinguishingly high moral and combat qualities as well as discipline. This was largely caused by the military clergy and the fact that the personnel of the army were highly religious. There was a clear organizational system of field clergy in the army; it was headed by the Reverend of the military ministry, the recent Chaplain of the Legion of the Ukrainian Sich Riflemen, Reverend Mykola Yizhak. There was a clear hierarchy within the clergy staff of the military organization, there were main offices in the headquarters of the army and corps, which subordinated the departments of the clergy serving with the smaller military units ${ }^{257}$.

Among the significant events of the time for the Greek-Catholic clergy there was one of a paramount importance. It was the congress in Stanislaviv on May 7-8, 1919, which was convened by Bishop Hryhoriy Khomyshyn on the instructions of the Metropolitan bishop (who remained in the blocked city of Lviv). The Congress called on to the clergy and the church followers and encouraged them to work hard and defend the independence of the West Ukrainian People's Republic from its enemies. It also sent greetings to the soldiers of the Galician $\operatorname{army}^{258}$. The clergy also addressed a memorial to the Apostolic Capital, in which they condemned the "behavior of the Roman Catholic (Polish) clergy in Volyn, Kholmshchyna and the occupied parts of the West Ukrainian People's Republic" 259 .

The Ukrainian-Polish war ended with the defeat of the West Ukrainian People's Republic, whose government and army retreated beyond the Zbruch River and united their forces with the Ukrainian People's Republic. On June 25, 1919, the Supreme Council of the Paris Peace Conference authorized the occupation of Eastern Galicia by Poland. It marked the beginning of the diplomatic struggle for restoration of independence of the republic. At the same time, the Greek Catholic clergy in the province face massive repressions. The Polish occupation authorities continued to keep A. Sheptytsky in

\footnotetext{
257 Вісник Державного Секретаріату Військових Справ. 1919. Ч. 6. С. 6.

258 Шах С. Вступне слово. Лебедович I. Полеві духовники Української Галицької Армії. Вінніпег, 1963. С. 19.

259 Кугутяк М. Історія української націонал-демократії 1918-1929. Т. 1. Київ; Івано-Франківськ, 2002. С. 132-133.
} 
isolation and prevented him from meeting J. Pilsudski, the head of the Second Commonwealth, when he visited Lviv in June 1919. In the end, Metropolitan bishop managed to send J. Pilsudski a letter requesting a release of about a thousand arrested and detained priests $^{260}$.

In August 1919 bishops Hryhoriy Khomyshyn and Josaphat Kotsylovsky together with A. Sheptytsky held a joint meeting in Przemysl and addressed a pastoral letter to the clergy and the church followers condemning the war, expressing condolences to those who had sacrificed their lives defending Ukraine, and expressed their hope for the future victory. Still the situation in the region was very difficult. The wrath of the war caused grief and brought enormous damage to the Ukrainian people and their $\operatorname{church}^{261}$.

Andrey Sheptytsky was kept under arrest in his Metropolitan Chambers until December 1919. The Polish authorities were aware of his great authority among people of the country and in the Vatican, therefore they tried to remove him from the metropolitan throne and get him away from Lviv in general. Warsaw suggested Pope to recall A. Sheptytsky to Rome, or transfer him to the North America. At the same time, Polish priests and the press inspired a large-scale action to compromise the Metropolitan bishop and ruin his reputation. In particular, head of the Stanislav Voivodeship Yuristovsky issued an order according to which all county constables were to collect materials that would help "to accuse Metropolitan bishop Sheptytsky of anti-Polish activity"262.

Following the Treaty of Riga, large territories inhabited by Ukrainians were included into the Second Commonwealth. According to calculations of Lviv ethnologist Stepan Makarchuk, there lived 4 million 686 thousand Ukrainians in Poland in the early 1920's. Most of them inhabited Lviv, Ternopil, Stanislav

260 Кривава книга. Дрогобич: Відродження, 1994. С. 75; Делятинський Р. І. Становище та діяльність духовенства станіславівської єпархії УГКЦ в 19191920 рр. Вісник Прикарпатського університету. Історія. Вип. VII. ІваноФранківськ, 2003. С. 69-77.

${ }^{261}$ Хома І. Апостольський престіл і Україна 1919-1922. Рим, 1987. С. 51.

${ }^{262}$ ЦДІАУЛ. Ф. 358. Оп. 1. Спр. 32. Арк. 154; Ф. 408. Оп. 1. Спр. 7. Арк. 1-7; Спр. 49. Арк. 1-3. Спр. 579. Арк. 2-20. 
Voivodeship and Volyn ( 3 million 920 thousand) ${ }^{263}$. Contrary to the international agreements on Galicia, the Polish government pursued a rigid occupation policy on its lands, as they sought to destroy Ukrainian institutions, and assimilate its population through the Polish influence. About 200,000 Polish colonists were relocated to Eastern Galicia, most of them former soldiers. These colonists were ousting Ukrainians from the border areas as well as many towns of the county ${ }^{264}$.

The post-war years prepared another challenge for the Greek Catholic Church. After his return from a three-year trip around Europe and America, during which Metropolitan bishop Andrey Sheptytsky had been trying to defend the rights of Western Ukrainians to have a national state and self-defining as a nation, he saw the total loss of faith by clergy and church goers as well as the destruction of spiritual shrines, which was all the result of military hostilities. Under these circumstances, he made a decision to bet on consolidation of national patriotic forces in order to revive and develop the church and to rebuild national life, and that became his main task. His Pastoral Epistle to the clergy and the faithful from July 12, 1923, called out for unity and solidarity ${ }^{265}$.

The Polish administration was extremely hostile when Metropolitan bishop wanted to return, they even tried not to let him get to Lviv, having detained him in Poznan for two months. He was considered capable of destabilizing political and religious life, and therefore he was thought to be an implacable enemy of the reborn Poland. A. Sheptytsky was supposed to promote "chauvinistic Ukrainian nationalism" and to exacerbate relations between Ukrainians and Poles, so he was really a persona non grata in the eyes of the Polish authorities ${ }^{266}$.

263 Макарчук С.А. Этносоциальное развитие и национальные отношения на западноукраинских землях в период империализма. Львов: Вища школа, 1983. C. 111.

264 Заборовський Я. Ю. Митрополит Андрей Шептицький. Нарис про життя i служіння церкві та народові 1865-1944. Митрополит Андрей Шептицький. Матеріали та документи. 2-ге вид. Львів; Івано-Франківськ: Олір, 1995. С. 42.

${ }^{265}$ Шептицький А. Пастирське послання. Церква і суспільне питання. Т. 2. К. 1. Львів: Місіонер, 1998. С. 212-215.

${ }^{266}$ Rzemieniuk F. Unici Polscy 1596-1946. Siedlce, 1998. S. 195-203. 
After the events of 1923, many Galician politicians and public figures started to understand that, under the circumstances, Ukrainians should fight for their national interests, taking the Polish political and legal system as a basis. It should be mentioned that the governmental decree from September 26, 1922 on self-government of the Lviv, Ternopil and Stanislav provinces declared certain rights for Ukrainians: it envisaged the creation of plenipotentiary Ukrainian local councils, it guaranteed access of Ukrainians to the administrative structures, it also promised equality of the GreekCatholic and Latin Catholic churches and an opening of the Ukrainian university. This decree was not the only one of its kind, similar documents used to be released from time to time, but they were not usually enforced, as it happened with the Concordat between the Holy See and Poland regarding the Ukrainian Greek-Catholic Church, which was adopted in $1925^{267}$.

The majority of scholars, who studied the modern Ukrainian history, pointed out that the national character of the Greek Catholic Church was finally crystallized in the interwar period of the twentieth century. There were 16 bishops under the leadership of Metropolitan bishop A. Sheptytsky. The Ukrainian Greek-Catholic Church in Galicia had 128 deaneries and 1907 parishes in the 1920's, and that was where 2298 priests worked $^{268}$. In addition, the Greek-Catholic church had its eparchies in the Transcarpathian region and overseas. However, on February 10, 1934, the Vatican Congregation for the Oriental Churches established the Apostolic Administration for the Lemkiv region. It was done without informing A. Sheptytsky, but by the agreement with Belvedere. This new structure was fully subordinated to the Vatican directly, and this fact strengthened the position of the Roman Catholic Church there and halted the process of ethnic identification of the Lemkos ${ }^{269}$.

\footnotetext{
${ }^{267}$ ЦДІАУЛ. Ф. 358. Оп. 3. Спр. 63. Арк. 2-8; Стемпень С. Поляки і українці в II Речі Посполитій і спроба діалогу. Украӥна-Польща: історична спадщина і суспільна свідомість. Київ: Либідь, 1993. С. 212; Історія релігії в Україні. Т. 4. Католицизм. С. 403.

${ }^{268}$ Prus Edward. Wtadyka Swiętojurski. Warszawa, 1985. S. 76-77.

269 Стоколос Н. Проблема етнічної і конфесійної ідентифікації лемків. Етнос $i$ релігія: теорія $і$ контекст сьогодення. Збірник наукових праць. Київ, 1998. C. $18-19$. 
Activities of Metropolitan bishop A. Sheptytsky and the clergy were focused on developing the influence of the church in the spheres of social, political, cultural and educational life of the region. The church maintained its parish libraries, folk choirs, amateur theaters, folk groups. Greek Catholic priests worked in different community organizations and societies, such as "Prosvita" ("Enlightenment"), "Ridna shkola" ("Native School"). The monastic orders also launched their missionary apostolic work, primarily the Basilians. They tried to strengthen ties with cooperatives ${ }^{270}$.

Being aware of the great influence Christian literature could have on people, church hierarchs led by A. Sheptytsky paid much attention to the works of religious publishers. The largest publishing center was the Basilian Publishing House, where the popular magazine "Missioner" ("Missionary") was published (with the circulation of $50,000$ copies $)^{271}$. Each eparchy published its own editions, the popular magazines were "Nyva" ("Field"), "Bohoslovia" ("Theology"), "Dzvony" ("Bells"), "Pravda" ("Truth"), "Meta" ("Aim"), "Nova Zorya" ("New Star"), "Beskyd", "Khrystos - nasha syla" ("Christ is our Might") and many others ${ }^{272}$.

Although in some of his speeches Metropolitan bishop A. Sheptytsky stated that the church should not interfere in politics, the situation forced the Ukrainian Greek-Catholic church to cooperate with the national-democratic political stratum, in particular the Ukrainian National Labour Party, and subsequently the Ukrainian National Democratic Alliance, and eventually it was forced to create their own parties ${ }^{273}$.

On August 4, 1925, there appeared the Ukrainian Christian Organization. Its creation was an initiative of $\mathrm{H}$. Khomyshyn, S. Tomashivsky, O. Nazaruk, Reverend T. Halushchynsky, and

270 Крутій-Вігоринський І. Друкарня оо. Василіян. Жовківщчина. Т. 2. Жовква; Львів; Балтимор. 1995. С. 195; Дрогомирецька Л. Греко-католицьке духовенство Галичини в українському кооперативному русі (1920-1939рр.). Вісник Прикарпатського університету. Вип. VII. Історія. С. 77-89.

${ }^{271}$ Жовківщина. Жовква; Львів; Балтимор. 1994. Т. 1. С. 155,167-169; Т. 2. С. 56-61, 190-197; Т. 3. 1997. С. 320-324.

272 Діло. 1926. 6 жовтня.

273 Федунків Зеновій-Роман. Греко-католицьке духовенство в просвітніх змаганнях галицьких українців. Нова зоря. 1993. Грудень. Ч. 40. 
Reverend V. Skruten. This Ukrainian Christian Organization stood on the positions of national democracy and was defending the autonomy of Galicia, promoting the concept of the monarchy, proposed by V. Lypynskyi. The main task of the organization was to popularize culture and education and to "bring up people on the religious and moral principles of the Catholic Church"274. However, people joined the ranks of the new structure rather slowly: in 1927 there were only 600 people in the Ukrainian Christian Union, and 381 of them were priests ${ }^{275}$. Under the auspices of the organization in the summer of 1934 , there was founded a network of reading rooms "Skala" ("Rock"), this network included some 14.3 thousand members and had 289 reading rooms in $1937^{276}$. The party had its printed edition starting from 1926, it was the magazine "Nova Zoria" ("New Dawn"). Being loyal to the Polish state, the party advocated the autonomy of Ukrainian lands and for some time it cooperated with Ukrainian National Democratic Alliance. However, the National Democrats constantly criticized the ritual innovations borrowed from the Latin rite (in particular, the introduction of celibacy) and introduced to the masses on the initiative of H. Khomyshyn and J. Kotsylovskyi; and this fact cooled down their relations with the bishops as well as the relations between the Ukrainian Christian Union and the Ukrainian National Democratic Alliance ${ }^{277}$.

In the course of the Catholic Action there was founded another clerical-conservative party in the fall of 1930. It was the Ukrainian Catholic People's Party (since 1932 it was called the Ukrainian People's Renewal), and it was the result of efforts of A. Sheptytsky. The party was headed by I. Volyanskiy, while its unofficial guardian

\footnotetext{
274 Нарис історії Станіславівської дієцезії. Нова Зоря. 1926. 28 квітня.

275 Єгрешій О. Григорій Хомишин і український націоналізм. Питання історії Украӥни: Зб. наук, статей. Чернівці, 2002. Т. 5. С. 101-104; Сгрешій О. Суспільно-політична та культурно-просвітницька діяльність єпископа Григорія Хомишина (1904-1945 рр.) Автореферат дис. на здобуття наук, ступеня канд. іст. наук. Івано-Франківськ, 2003. С. 11.

${ }^{276}$ ЦДІАУЛ. Ф. 201. Оп. 46. Спр. 2626. Арк. 59; Ф. 358. Оп. 1. Спр. 42. Арк. 1-7.

277 УХО та її завдання. Наші вicmi. 1925. Ч. 1. С. 5-6; ЦДІАУЛ. Ф. 408, оп. 1, спр. 592, арк. 1-20; Стемпень С. Між окциденталізацією та візинтинізацією: проблема обрядової ідентичності Греко-католицької церкви в Речі Посполитій міжвоєнного періоду. Ковчег. Львів, 2003. Ч. 4. С. 86-99.
} 
was H. Khomyshyn. The new party demanded national-territorial autonomy for Ukrainian lands under the Polish rule. However, the party failed to establish its network and did not hold any party congresses. At the same time, party leaders took active part in consolidation efforts to unite Ukrainian nationalism during the AllUkrainian National Congress meetings (1933-1936). In the elections to the highest legislative bodies of Poland $(1935,1938)$, this party made an agreement with the Ukrainian National Democratic Alliance and nominated a candidate for an ambassador to the Parliament and for a senator, having the consent of the government ${ }^{278}$. At the same time, namely on January 1, 1931, in opposition to H. Khomyshyn, Metropolitan bishop A. Sheptytsky initiated creation of the Ukrainian Catholic Union $^{279}$. In this way, the hierarch of the church actually expressed his disagreement with the policies of the certain leaders of the Ukrainian National Democratic Alliance. In particular, there was some dissatisfaction with compromise of the Ukrainian SocialRadical Party and the Ukrainian Social-Democratic Party. He also was seeking to strengthen his own political role. There were also published the weekly magazine "Meta" ("Purpose") with the supplement "Hrystos - nasha syla" ("Christ is Our Might"), the literary and scientific monthly magazine "Dzvony" ("Bells") (19311939, J. Slipyj was the editor-in-chief) $)^{280}$.

The large-scale Catholic Action of the 1930s contributed to the strengthening of church structures and their connection with the most remote parishes. As it is known, the encyclical of Pope Pius XI in 1922 was the impulse of the Action, as it was written because of the influence the world war and social revolutions had left, together with the manifestations of chauvinism and militant atheist communism. It defined the great potential of the common people in the pursuit of peace and freedom.

\footnotetext{
278 Швагуляк М. Українська католицька народна партія. Довідник з історії Украӥни. Київ, 2002. С. 921.

279 Роль і місце мирян в церкві. Інформаиійний бюлетень. Львів, 1998. С. 21; Діло. 1930. 26 квітня.

${ }^{280}$ Швагуляк М. Християнський католицький союз. Довідник з історії України. Київ, 2002. С. 964-965.
} 
The course of the Catholic Action took place in rather unfavorable conditions. In the summer of 1930, a large-scale sabotage campaign was carried out by the Organization of Ukrainian Nationalists. In the course of the campaign, at least 2,200 terrorist attacks happened as well as arsons of landlords' mansions and police positions, and "Strzeltsi" centers ${ }^{281}$. As a reaction to these actions, the authorities sent gendarmerie units and military units to Ukrainian villages. There was the principle of collective responsibility, which was exploited as a main principle of this "pacification".

Police reports were full of information about the "anti-Polish" publications, press and leaflets of the Ukrainian Military Organization - Organization of the Ukrainian Nationalists, which were confiscated from priests, and many parishioners were deprived of weapons ${ }^{282}$. The hierarchs of the Greek Catholic Church condemned both sabotage actions and mass military and political repressions on the side of the authorities. Metropolitan A. Sheptytsky went to Warsaw, but Polish leadership, in particular J. Pilsudski, refused to meet him. Therefore, A.Sheptytsky appealed to Pope Pius XI together with the bishops. It was even in the League of Nations that the Galicia's case was discussed ${ }^{283}$.

The international feedback on the "pacification" contributed to the Ukraine's desire to unite its national forces. This should have been facilitated by the Catholic Action, which was headed by a committee led by Bishop Ivan Buchko. First of all, the activity of mass religious congregations became more evident. Within a year, the Apostleship of Prayer managed to unite more than 100,000 Galicians, while the 229 Marian organizations managed to gather 17,000. A significant event of the Action was the formation of the Catholic Action of Ukrainian Youth (CAUY) on the initiative of Metropolitan bishop. It was supposed to educate youth in the Christian and national-patriotic

${ }^{281}$ Кугутяк М. Галичина: сторінки історії. Івано-Франківськ, 1993. С. 183.

282 ДАЛО. Ф. 121. Оп. 3. Спр. 630. Арк. 11-15; ЦДІАУЛ. Ф. 358. Оп. 8. Спр. 44. Арк. 34; Rzemieniuk F. Unici Polscy 1596-1946. Siedlce, 1998. S. 208-209; Швагуляк М. «Пацифікація». Польська репресивна акція у Галичині 1930 р. i українське суспільство. Львів, 1993. С. 10-33.

${ }^{283}$ Два документи Ватикану в справі пацифікації. Діло. 1931. 4 червня. 
spirit $^{284}$. The formation of CAUY was proclaimed on May 7, 1933, at a festive assembly of 60,000 boys and girls from all over Galicia in Lviv. Metropolitan bishop A. Sheptytsky was also present there $^{285}$. The ranks of the youth organization included "Luhy" (about 47,000 members; 1937), "Plast" $(6,000 ; 1930)$, the League of Ukrainian Students, and other communities influenced by the Greek Catholic Church ${ }^{286}$. In 1934 the General Institute became the governing body of the Catholic Action, and it published the magazine "Katolytska aktsia" ("Catholic Action").

The leadership of the Greek Catholic Church kept a close eye on the events in the Soviet Ukraine, where patriotic Ukrainians faced mass repression and terror. Religious magazines constantly informed readers about the terrible destruction of the church in the Stalin empire, arrests and exile of Metropolitan bishop V. Lypkivsky together with twelve bishops and several hundred priests to Solovetsky concentration camps ${ }^{287}$. The press pointed out the crimes of the Stalinist regime against its own people, emphasizing that Bolshevism and communism were the greatest enemies of society. The issue of Famine in the Soviet Ukraine gained a lot of attention. In December 1932, in Lviv, political and ecclesiastical officials considered the problem of famine in Ukraine and had an intention to send a special commission there. On July 24, 1933, Metropolitan bishop A. Sheptytsky, together with all the bishops of the church, issued an alarming note "In the cause of events in Great Ukraine to all people of good will", which was full of concern for Ukrainian people's fate ${ }^{288}$. In those days the magazine "Missionary" published an editorial by Reverend R. Krynytsky called "No Words...", which stated that the Kremlin leaders were "exterminating the 40 million nation by means of famine" 289 . It is worth mentioning that the leaders

\footnotetext{
${ }^{284}$ Роль і місце мирян в церкві. Інформаційний бюлетень. Львів, 1998. С. 23. 285 Ibid.

286 Трофим'як Б. Фізичне виховання і спортивний рух у Західній Україні (з поч. 30-х рр. ХІХ ст. до 1939 р.). Київ, 1997. С. 162-164, 250-256; Вацеба О. Нариси 3 історії західноукраїнського спортивного руху. Івано-Франківськ, 1997. C. 124-130.

${ }^{287}$ Місіонар. 1926. Ч. 11. С. 242; ЦДІАУЛ. Ф. 408, оп. 1, спр. 13, арк. 1-4.

${ }^{288}$ Мiciонар. 1937. Ч. 9. C. 203.

${ }^{289}$ Ibid.C. 202.
} 
of the Ukrainian Greek-Catholic church joined the Public Rescue Committee of Ukraine created together with the public and political figures of Galicia. Their task was to collect donations for the starving, but those donations were not accepted by the Soviet government.

The Galician political elite were anxiously watching as the confessional and ethnic transformations in Transcarpathia took place. At that moment, Transcarpathia was a part of Czechoslovakia, and in the 1920s there was an active campaign for people to convert to Orthodoxy, which was, in fact, initiated by the active Russian emigrants of the empire period, and which was supported by the Czech government. For purely political reasons official Prague tried to weaken the influence of the Greek Catholic Church, to separate local population religiously and nationally, to get them lost in the multiethnic (Hungarian, Romanians, Slovaks, etc.) environment ${ }^{290}$.

Metropolitan bishop A. Sheptytsky paid great attention to the development and spread of culture and education. He was particularly serious about the organizational patronage over public structures of public trusteeship - trustee societies, orphans protections and burial committees. He tried to support financially and morally the underprivileged Western Ukrainian population. It was at the end of the First World War, on March 23, 1918, when the first meeting of the charitable society took place in the St. George Cathedral in Lviv, with the participation of H. Khomyshyn, S. Fedak, and K. Studynsky. Shortly afterwards this society got the name "Protection of Metropolitan bishop Andrey Sheptytskyi for Orphans in Lviv". Its material basis was the "honorary gift" of its patron after he had returned from the Russian captivity. The Society purchased lands for charity purposes in Zarvanytsya, some real estate in the village Korshiv, a forest in Bohorodchany region. It looked after hundreds of children $^{291}$. In 1924 , there were more than 1,300 children in the

\footnotetext{
290 Столокос Н. Після Ужгородської унії. Етноконфесійні трансформації та адаптація греко-католиків Закарпаття. Людина і світ. 2001. № 5. С. 2-7.

291 Савчук Б. Просвітницька та соціально-економічна діяльність українських громадських товариств у Галичині (остання третина XIX - кінець 30-х рр. ХХ ст.). Івано-Франківськ, 1999. С. 81.
} 
similar ecclesiastical institutions of the Lviv Diocese, Stanislav and Przemysl Eparchies ${ }^{292}$.

In order to organize the collection of donations, the Metropolitan ordinance allocated specific counties to concrete societies ${ }^{293}$. It was also important that they were not only various church structures (diocesan committees of orphans' care, St. Josaphat Institute in Lviv, Mary's Ladies' Associations, etc.) that took part in charitable events. Some local community organizations like "Ridna shkola" ("Native School"), "Ukrainska zakhoronka" ("Ukrainian Burial Community"), Ukrainian Regional Society on Care for Disabled and others were also much involved.

In order to socially support the widows and orphans of priests, there was set up an Aid Committee in Lviv in 1926 under the protection of the Metropolitan bishop. It dealt with voluntary donations of priests and secular individuals; priests had a recommendation to pay 3 zloty's (since 1936 - 5) to the deceased's heir. In 1929 the Committee bought a two-storey house on the street Sheptytsky, 38, with the financial support of the Institute of Widows and Orphans ${ }^{294}$. There were also some donations from Diaspora and the Metropolitan ordinariate forwarded some of this money to the Ukrainian Fund for Military Widows and Orphans in Lviv. In 1930 this fund took care of 130 people, all of whom received the sum of 10 zloty's five times a year ${ }^{295}$. The community "Ukrainska zakhoronka" ("Ukrainian Burial Community", which was established in 1933) was also subsidized by the Metropolis, in the mid-1930s these communities cared about 500 children in 8 institutions around the city of Lviv, they also had two free canteens for the under aged. There was also functioning a number of other

\footnotetext{
292 Гнот С. Греко-католицька церква і організація суспільної опіки Галичини (1921-1939). Актуальні проблеми державного управління. Вип. 6. Львів, 2001. C. 300 .

293 Львівські архієпархальні відомості. 1925. 1 жовтня.

${ }^{294}$ Нова Зоря. 1926. 31 грудня; Ibid.1932. 15 червня; Ibid.1936. Червень.

295 ЦДІАУЛ. Ф. 358. Оп. 1. Спр. 115. Арк. 68; Ibid.Спр. 108. Арк. 8; Діло. 1931. 8 травня; Ibid.1939. 9 червня.
} 
clerical and philanthropic societies ("Dolia"/“Fate", "Buduchnist"/“Future", etc.) ${ }^{296}$.

There was also constant financial and organizational assistance provided to the Ukrainian Regional Society on Care for Disabled (created in 1921-1922, the chairman was D. Paliyiv, since 1932 it was headed by doctor S. Hyzha), which took care of the sick veterans of the Ukrainian Galician Army. Traditional fundraising events were held on the Green Holidays, November 1, and during various social, cultural and religious events ${ }^{297}$.

The majority of listed above public organizations founded the Ukrainian Council of Public Trustees. They did it together with bishop ordinariates on March 17, 1933. The council coordinated activity of Ukrainian organizations, promoted the idea of public custody among people, as well as the legal framework for this type of social work ${ }^{298}$.

With the participation of the priesthood, they revived the work of the anti-alcohol and anti-nicotine society "Vidrodzhennia" ("Renaissance") (created in 1909 on the basis of church sobriety fraternities). In 1931 Galician priests actively participated in the organization of local plebiscites on the problem of existence of taverns in the villages ${ }^{299}$. The largest public action of the society was the holiday of the ascetic sobriety movement, which was organized in honor of Metropolitan bishop Yosyf Sembratovych. It took place on May 23, 1937 in Lviv at the square called "Sokil-Batko" ("FatherFalcon"). March of several thousands and the celebration, in which Metropolitan Bishop A. Sheptytskyi and high clergy took part, proved

\footnotetext{
296 Гнот С. Греко-католицька церква і організація суспільної опіки Галичини (1921-1939). Актуальні проблеми державного управління. Вип. 6. Львів, 2001. С. 303; Дутчак П. Клерикально-філантропічні товариства в Західній Україні (20-30-ті рр. ХХ ст.). Питання історії України. Т. 6. Чернівці, 2003. С. 154-157. 297 ЦДІАУЛ. Ф. 358. Оп. 1. Спр. 131. Арк. 2-30; Савчук Б. Просвітницька та соціально-економічна діяльність українських громадських товариств у Галичині (остання третина XIX - кінець 30-х рр. XX ст.). Івано-Франківськ, 1999. С. 78-79; Нова Зоря. 1927. 13 лютого; Діло. 1932. 26 березня.

298 Діло. 1933. 6 травня.

${ }^{299}$ ЦДІАУЛ. Ф. 358. Оп. 1. Спр. 136. Арк. 1-20; Федунків 3.-Р. Протиалкогольне товариство «Відродження». Нова зоря. 1993. Жовтень. Ч. 37; Каховський І. За тверезість. Короткий історичний огляд Українського протиалкогольного й протинікотинового руху. Львів, 1934. 48 с.
} 
that anti-alcohol and anti-nicotine ideas were supported by Galicians $^{300}$.

Metropolitan Andrey Sheptytsky was one of the initiators of the conservation of the nature of the Carpathian region. He became the sponsor of the cedar reservation in the vicinity of Mount Yaitse. Purchased in 1936 by Metropolitan bishop, the steppe reservation "Devil's Mountain" in the Rohatyn region was given into the scientific care of Shevchenko Scientific Society. In general, in the Carpathian Gorgans, a lot of forest land was owned by the Greek Catholic Consistory, which enabled the Ukrainian naturalists to develop effective conservation activities ${ }^{301}$.

After World War I, the archives and library of the Metropolitan Ordinariate were refitted and supplemented. The library catalog consisted of 32 sections, including archives, manuscripts, UkrainianPolish and Ukrainian-Moscow cases, dictionaries and encyclopedias, maps and plans. The library also included works by the Ukrainian People's Republic and the West Ukrainian People's Republic activists, "Red Guelder Rose Chronicle", books of the nationalpatriotic publishing house "Chervona Kalyna" ("Red Guelder Rose") on the history of Cossacks period and Liberation struggle of the first third of the XX century ${ }^{302}$.

The Archives of the Metropolitan Ordinary consisted of two large sections: old acts and new acts. The search and analytical work of the archive was coordinated by Professor Ivan Shendryk, who prepared "Materials for bibliography of the Sich Riflemen" (Lviv, 1937, 61 p.). It was later published in the series of the Bibliographic Commission of the Shevchenko Scientific Society "Materials to the Ukrainian bibliography" ${ }^{, 303}$.

\footnotetext{
300 Савчук Б. Корчма: алкогольна політика і рух тверезості в Західній Україні у XIX - 30-х роках XX ст. Івано-Франківськ, 2001. С. 168-171.

${ }^{301}$ ЦДІАУЛ. Ф. 358. Оп. 1. Спр. 78. Арк. 1.

302 Васьків А. Бібліотека і архів Митрополичого ординаріату Греко-католицької церкви після Першої світової війни. Республіканець. 1994. № 5-9. С. 85-88; ЦДІА України у Львові. Ф. 408. Оп. 1. Спр. 686. Арк. 3; Ibid. Спр. 711. Арк. 54. 303 Ibid. Спр. 688. Арк. 6-10, 63; Ibid. Спр. 705. Арк. 1, 56; Центральний державний історичний архів України, м. Львів. Путівник. Львів; Київ, 2001. С. 231-232.
} 
The personal library of A. Sheptytsky was also well-completed and stuffed. In the late 1930s it included 4 thousands of items to be preserved (its inventory manuscripts were well-preserved in the Department of V. Stefanyk Lviv National Academic Library). They included ancient books and books printed in the $16^{\text {th }}$ century, literature on church history (in Ukrainian, Russian, German, Serbian and Croatian, Polish, French); there was also a large collection of editions on the history of Ukraine, local history, country study and folklore ${ }^{304}$.

Before the beginning of World War II, the Ukrainian Greek Catholic Church was one of the most respected institutions in Poland, it was an important element of the Universal Church and played a prominent role in the socio-political and national life of the Western Ukraine. It consisted of five dioceses (eparchies), the Apostolic Administration for Lemkivshchyna, the Apostolic Visitation Office of Volyn, and there worked 10 bishops, 2950 priests, 520 hieromonks, 1090 nuns, 540 students of theology ${ }^{305} .4 .3$ million Greek Catholics were members of 3040 parishes, 4440 churches and 195 monasteries $^{306}$. There were 40 religious congregations in the Carpathian region and they carried out their purposeful pastoral work. 35 publishers prepared and printed out thousands of books and 38 periodicals. In particular, a bi-weekly magazine of the Ukrainian Catholic organization "Nova Zoria" ("New Dawn"), which was first published on January 7, 1926, stood on the "defense of the Catholic worldview... before the onslaught of Bolshevism" and "modern sectarianism, 307 .

In October 1929, on the basis of a seminary, there was established the Theological Academy. Its work was seriously favoured by Metropolitan bishop A. Sheptytsky, and it made a significant

\footnotetext{
304 Дзьобан О. Бібліотека митрополита Андрея Шептицького у Львові. Записки Львівської наукової бібліотеки ім. В. Стефаника. Львів, 2002. Вип. 9/10. С. 141-151; Львівська наукова бібліотека ім. В. Стефаника НАН України. Відділ рукописів. Ф. 9, спр. 5002.

305 Гордієнко В. Сталінізм і Українська греко-католицька церква. Матеріали наук. конференції. Львів, 1990. С. 43.

306 Великий А.Г., ЧСВВ. Світло і тіні української історії. Причинки до історії української церковної думки. Рим: вид. оо. Василіян: 1969. С. 163.

${ }^{307}$ Мельничук П. 3 історії «Нової зорі». Нова зоря. 1991. Червень. Ч. 11-12.
} 
contribution to the development of national education, preservation of historical and cultural monuments. The rector of the Academy Josyf Slipyj hired well-known representatives of science, culture and clergy to the professorial and pedagogical staff of the institution, in particular the headmaster of the Museum of Taras Shevchenko Scientific Society Yaroslav Pasternak, historians Ivan Krypiakevych $^{308}$ and Mykola Chubatyi, archaeologist Yurii Poliansky and others. There was established a special church museum which was situated in five halls of the Academy, and it was a well-known researcher of church architecture, Mykhailo Drahan ${ }^{309}$, who headed it.

There were five seminaries, which prepared the future priests. The Ukrainian clergy carried out their catechetical and educational work in 8 thousand national, 380 secondary and several higher schools, and they had 520 national, 20 secondary and higher educational institutions under their rule ${ }^{310}$.

During that period it was the Ukrainian Theological Society (UBT, founded in 1923), which managed to become an important center of scientific, historical and theological studies. Its members were purposefully working on the information about the church history; they were especially interested in studying Episcopal visits. The "Archive of the Union History", which was founded in 1928 by A. Sheptytsky, was also very functional while conducting analytical and archeographic activity. Its staff organized a large archeographic corpus and worked on a series of explorations that were to summarize the process of historical transformation of the Eastern Church of the early modern period on the UkrainianBelarusian territories ${ }^{311}$.

308 Іван Крип'якевич у родинній традиції, науці, суспільстві. Львів, 2001. С. 7-16, 569-571.

309 ЦДІАУЛ. Ф. 408. Оп. 1. Спр. 24. Арк. 1-3; Коваль І. Ярослав Пастернак основоположник української церковної археології. Нова зоря. 1999. 26 травня; Бандрівський М. Пам'яткоохоронна діяльність Церкви в контексті національнокультурного руху в Галичині (кінець XIX - XX ст.). Автореферат дис. на здобуття наук, ступеня канд. іст. наук. Львів, 2001. С. 11.

310 ЦДІАУЛ. Ф. 408. Оп. 1. Спр. 606. Арк. 1-7; Ibid. Спр. 608. Арк. 1; Ibid. Спр. 615 Арк. 1-3.

311 ЦДІАУЛ. Ф. 408. Оп. 1. Спр. 816. Арк. 1-4; Ibid. Спр. 825. Арк. 2-6; Ibid. Спр. 824. Арк. 2-56; Скочиляс I. Дослідження візитаційної документації 
Metropolitan bishop Andrey Sheptytsky remained the head of the Ukrainian Greek Catholic Church for the total of 44 years, under the Austrian-Hungarian, Russian, Polish rules, and German and Soviet occupations. He proved to be an experienced religious, social and political figure, acting under extremely difficult conditions. The great majority of historians, political scientists, religious scholars, his advocates and foes cannot deny, but acknowledge his tremendous contribution into the strengthening of the church, protection of the national and religious needs of the church followers, and the political consolidation of Ukrainians.

It was thanks to the diplomatic talent of Andrey Sheptytsky that the magnificent organization of the Ukrainian Greek-Catholic Church was preserved in the turmoil of World War II, as well as during the epochs of Soviet and German totalitarianism. It was in 1944, after the death of Metropolitan bishop that the authorities decided to implement their long-standing intention to wipe the church away from the earth's face.

Львівської єпархії у Галичині в другій половині XIX - першій половині ХХ століття. Ковчег. Ч. 3. Львів, 2001. С. 483-488. 


\section{PART 4. \\ CONFESSIONAL-ETHNIC AND POLITICAL TRANSFORMATIONS DURING THE SECOND WORLD WAR (1939-1945)}

The middle, as well as the beginning of the twentieth century, had brought great ethno-religious transformations to Ukraine. Ukrainians were challenged by a new world war, mass repression of the Stalinist and Hitler's regimes. Ukrainians have suffered the greatest demographic losses among all the nations of Europe: scientists estimate that today the population of Ukraine could have reached approximately 100 million $^{312}$. Western Ukrainian areas were constantly in the center of military and political confrontation and armed struggle of foreign states. The church-religious complex of the region, that was annexed to the USSR as a result of World War II, has been damaged ${ }^{313}$. The confrontation of the church to the new communist government ended in disaster.

Under the totalitarian regime in the USSR, the priority of the ruling Communist Party was the struggle for influencing people's consciousness, its denationalization. The concepts of Christian morality were not within the ideological framework of the system. Consequently, the relations of the militant-atheist government with the church in Ukraine, whose people have always been deeply religious, often took radical confronting forms. After the affiliation of Western Ukraine to the USSR in the fall of 1939 and the defeat of the Ukrainian Orthodox Church in the Soviet Ukraine and the elimination of denominations that were supporting independence of the state and clergy, Moscow faced an organizationally strong and dangerous opponent - the UGCC.

312 Кульчицький С. Нi, то не був подарунок долі. Високий Замок. 1999. 18 серпня.

313 Литвин М., Луцький О., Науменко К. 1939. Західні землі України. Львів, 1999. $152 \mathrm{c}$ 
Before World War II, the Greek Catholic Church was one of the most respected in the Second Polish Republic and played a prominent role in the socio-political and national-cultural life of Western Ukraine. Its majestic structure consisted of 3040 parishes uniting 4.3 million believers, 4440 temples and chapels, the Theological Academy in Lviv, five theological seminaries, two theological schools, 127 monasteries and monastic houses ${ }^{314}$. The UGCC was the generator of the historical memory and national consciousness of Galician Ukrainians and resisted to the assimilatory policy of Warsaw. The guarantor of the ethnocentric course of the church in the XX century was its Metropolitan Andrey Sheptytsky - a man with the extraordinary human and civil qualities, an experienced parliamentarian, a consistent supporter of national and cultural rights of the people. The church under his authority in 1939 had 10 bishops, 2,950 priests, 520 hieromonks, 1,090 nuns and 540 theology students $^{315}$. The UGCC facilitated the development of Ukrainian business life, the formation of national economic, production, banking and museum structures, it was engaged in charity and philanthropy. Besides the Greek Catholics there were numerous and organized denominations of Roman Catholics ( 2 million), Orthodox (1.5 million, mainly in Volyn and Chelm) and Jews (0.8 million) ${ }^{316}$.

After the Western Ukraine's annexation in the fall of 1939, the Bolshevik authorities, providing the so-called "sovietization" of these lands, launched a widespread attack on religion and in particular on the Greek Catholic Church, as an important factor in the spiritual and political life of the region. First of all, its educational institutions were closed: The Theological Academy, theological seminaries, scientific

${ }^{314}$ Реєнт О.П., Лисенко О.С. Українська національна ідея і християнство. Київ: Богдана. 1997. С. 94.

315 Гордієнко В. Сталінізм і Українська греко-католицька церква. Матеріали міжнародної конферениї присвяченої життю $i$ діяльності митрополита Андрея Шептицького. Львів, 1990. С. 43.

316 ЦДІАУЛ. Ф. 358. Оп. 1. Спр. 112, 114, 118, 119, 124, 126, 128, 129, 132; Макарчук С. Этносоциальное развитие и национальные отношения на западноукраинских землях в период империализма. Львов, 1983. С. 146-148; Ковалюк В. Культурологічні та духовні аспекти «радянізації» Західної України (вересень 1939 - червень 1941). Украӥнський історичний журнал. 1993. № 2. C. 10 . 
institutions (Theological Scientific Society, etc.), publishing houses, religious publications were suspended and teaching of religion in schools and universities was cancelled. In other words, the first stage of the "sovietization" of the spiritual life of society was provided by eliminating the influence of the church on the believers.

The new authorities also made a huge damage to the Roman Catholic Church. "Priests and rabbis, those faithful slaves of the enemies, are actively manifesting their anti-people's activities", the Moscow magazine "Communist Education" noted on that days ${ }^{317}$. The NKVD structures, as well as the party and state authorities, followed the directive of the People's Commissar for Internal Affairs of the USSR L. Beria from September 15, 1939: "to clear the annexed territories from "hostile elements". They used well-known methods of struggle for the power - the mass repressions. Therefore, the priests were in the first wave of arrests and deportations in February 1940, when hundreds of thousands of Westerners were deported to the North and to Siberia ${ }^{318}$.

The repressive measures of the Soviet authorities did not bypass their serious opponent, the UGCC. On the first day of the war, on September 1, 1939, when the German bombardment of the Ukrainian cities of Lviv, Ternopil, Stanislaviv had started, the Metropolitan ordination addressed the clergy with a request to remain calm and warn the believers against the ideological invasion of provocateurs and communists ${ }^{319}$.

The new regime interpreted the historical mission of the Greek Catholic Church very carefully and step by step restricted its activities. Metropolitan A. Sheptytsky wrote in a letter to Rome on December 26, 1939: The Bolsheviks made great efforts "only to conquer, oppress, and destroy us". Summing up the consequences of the criminal acts of the authorities, he emphasized: "The number of victims who were deported, imprisoned or killed is very high. Only in

${ }^{317}$ Комуністична освіта. 1940. № 9. С. 18.

318 Депортації. Західні землі України кінця 30-х - поч. 50-х рр. Т. 1. Львів, 1996; Депортації українців та поляків: кінець 1939 - початок 50-х років. Львів, 1998. С. 74-76.

319 Сурмач О. Державно-церковні відносини на західноукраїнських землях (1939-1941). 1939 рік в історичній долі Украӥни і українців. Львів, 2001. С. 171. 
my eparchy, it is about 20,000 people. In my eparchy 12 priests were killed or died in prison, and about 20 in the Przemysl Eparchy. In addition, 33 priests were deported from my eparchy to Siberia" ${ }^{320}$. It should be emphasized that about one hundred priests moved across the San River to the German territory threatened by repressions.

Under such difficult conditions of the militant atheism system, the Greek Catholic Church had the smallest amount of loss among other denominations and was able to resist the Bolshevik anti-religious policies in an organized and effective manner. This merit belongs primarily to Metropolitan Andrey, who united the clergy and consistently followed the course he proclaimed concerning the new authorities, which was not favorable to $\mathrm{it}^{321}$. Lviv historian of the church Mykhaylo Haikovsky rightly points out that in one of the messages Andrey Sheptytsky clearly stated the approach of the Greek Catholic Church to the Bolshevik authorities. According to his words, "to obey the Laws, because they are not contrary to God's law", as well as to "not interfere with politics and secular affairs", there is a transparent position. He called not to support the new authorities, which from the first days tried to involve the masses in the political struggle of the poor against the rich, the bourgeoisie and other "enemies of the people"322.

Nevertheless, Moscow and Kyiv still abstained from radical measures to eliminate the UGCC, although its anti-Soviet orientation was well known. In our opinion, a radical course to eliminate the Greek Catholic Church - a recognized defender of the interests of the Ukrainian people in Poland - would contradict J. Stalin's main argument regarding the September 17, 1939 invasion: "to take under protection the Ukrainian population". The important thing is that on September 27 of the same year, after the start of the war actions by the Red Army, the Kyiv radio expressed gratitude to the Galician clergy for having "supported so faithfully the Ukrainian spirit of the

\footnotetext{
${ }^{320}$ Реєнт О.П., Лисенко О.С. Українська національна ідея і християнство. Київ: Богдана. 1997. С. 95.

321 Шептицький Андрей, митрополит. До духовенства. Львівські єпархіальні відомості. 1939. № 9-10. С. 205.

322 Гайковський М. Велике протистояння: опір греко-католицької церкви більшовицькому окупаційному режимові (вересень 1939 - червень 1941). Київська цеерква. 1999. № 5. С. 26.
} 
enslaved people",323. As V. Lentsyk rightly emphasized, two more important circumstances contributed to this: the uncertain situation in the region after the beginning of World War II, as well as the indisputable authority of Metropolitan Andrey Sheptytsky ${ }^{324}$.

Not daring liquidate the UGCC, the Soviet authorities used great economic oppression: they nationalized all church lands, confiscated a big amount of buildings, imposed excessive taxes. The monasteries had particularly significant losses. In the fall of 1939, the red "liberators" carried out a search in the Monastery in Hoshiv - they confiscated watches, razors and other things from the monks. All the buildings except the church were occupied by the army until 1941 and left furniture, pierced with bayonets, broken walls and doors ${ }^{325}$.

Church-religious magazines and publishing houses were liquidated. The activities of the Theological Scientific Society were prohibited. Its book collection was destroyed - 12,000 volumes, including 500 old books and manuscripts, 150 sets of journals in Ukrainian, Polish, Russian, German, English and other languages, as well as the scientific papers of theologians of the 1930's ${ }^{326}$.

Metropolitan sent an appeal letter directly to M. Khrushchev. In a letter, he informed the Secretary of the Central Committee of the CPSU about excessive taxes on clergy, the failure of which would lead to the prosecution of the priests. There is an impression, Metropolitan emphasized, that it was not so much about religious taxes ("cultural tax"), but "about the destruction of the Ukrainian clergy". At the same time, he drew M. Khrushchev's attention to extensive taxes on the peasants ${ }^{327}$.

When the People's Assembly of Western Ukraine in October 1939 adopted Declarations and decrees prepared in Moscow, including the confiscation of church lands and the liquidation of monasteries, Metropolitan Andrey Sheptytsky declared them illegal and openly protested. In a letter to the priesthood and monastic congregations,

\footnotetext{
${ }^{323}$ ЦДІАУЛ. Ф. 684. Оп. 2. Спр. 92. Арк. 95.

324 Західна Україна під большевиками. IX. 1939 - VI. 1941 / Збірник під редакцією М. Рудницької. Нью-Йорк, 1958. С. 143.

325 Яновський М. Правда про Гошівський монастир. Нова зоря. 1994. Січень. Ч. 2 .

326 Антонюк Н. В. Українське культурне життя в «Генеральній губернії» (19391944 рр.). Львів, 1997. С. 158.

${ }^{327}$ ЦДІАУЛ. Ф. 201. Оп. 4. Спр. 2632. Арк. 18.
} 
Metropolitan wrote indignantly: "The military circumstances have forced us to remain silent until now and not to be able to stand resolutely in your defense against violence. That is the most painful, because it had been covered by the lie expressed by the will of the people. This silence is contrary to our will. Let no one interpret that we agree with the spirit of violence. We do not agree, but we are also strongly protesting against the wrongdoing towards you" ${ }^{\text {"328. In }}$ particular, Metropolitan protested that part of the Declaration of the Peoples' Assembly, which proclaimed the confiscation of church lands and the liquidation of monasteries.

Metropolitan A. Sheptytsky did his best to maintain the church and its believers under new conditions. He prohibited the priests to leave the parishes, and continued to maintain relations with the Apostolic See. In October 1939, he secretly sent a trusted person to Pope Pius XII with a letter referring to the ordination of the rector of the Theological Academy Fr. Josyf Slipyj as the Bishop, the possible successor to the Metropolitan throne. Pope Pius XII, at the request of Metropolitan, approved the action of spreading the Uniate on the territory of the USSR, that was initiated by the secret Lviv Council of September 18-19, 1940. Metropolitan established four exarchates outside Galicia and appointed exarchs in the Soviet Ukraine (Bishop J. Slipyj), Russia (Student-monk K. Sheptytsky), Belarus (Bishop A. Nemantsevich), Volyn, Chelm region and Podlachia (Bishop M. Charnetsky). The main canonical, liturgical, and pastoral foundations of the new structure of the UGCC were established at the Council of the Exarchs. After some hesitations, Pope Pius XII approved the Exarchs as Apostolic at the end of 1941, and Metropolitan Andrey as the Apostolic Delegate for the Exarchs. So, under extremely difficult circumstances, the UGCC not only survived but also extended to a large territory of the East ${ }^{329}$. Metropolitan initiated the purification of the church from Latin rites, was preparing missionaries for apostolic work in the eastern regions, where many Ukrainian immigrants lived for a long time.

\footnotetext{
${ }^{328}$ ЦДІАУЛ. Ф. 358. Оп. 3. Спр. 12. Арк. 12-13.

329 Сапеляк А. Київська церква на слов'янському Сході. Буенос-Айрес; Львів: Інститут українознавства ім. І. Крип'якевича НАНУ, 1999. С. 168.
} 
According to the large number $(10 \%)$ of the deported population of the Western Ukraine ${ }^{330}$, Metropolitan tried to send Greek Catholic priests to their displacement areas (Siberia, Kazakhstan, the Far East). Moreover, he personally tried to go there ${ }^{331}$.

The annexation of the Western Ukrainian lands to the USSR was carried out with strong violation of the principles of international law. It was based on violence and ignoring of civilized norms of interstate relations and Christian morality. The policy of "sovietization" of 1939-1941 by totalitarian authorities in fact displaced the church from official social life and removed important social functions from it education, charity, financial and economic activities.

The beginning of the Soviet-German war on June 22, 1941 changed the religious situation in the Western Ukrainian lands, which were already occupied by the Wehrmacht troops in the first weeks of war. The OUN leadership, taking advantages of new geopolitical circumstances, proclaimed the Act of Restoration of the Ukrainian State on June 30, 1941 in Lviv. Very soon, on July 1, the Pastoral Letter of Metropolitan A. Sheptytsky stated: "With the will of the almighty and merciful God, united in the Trinity, a new era began in the life of the United State of Independent Ukraine. Military circumstances require many more victims, but this case, which was born in the name of God and with the grace of God will be brought to a successful end... The Ukrainian people must show in that historical wave that they have a sufficient sense of authority, solidarity and vitality to deserve a position among the peoples of Europe and develop it's own forces, that were given by God... We recognize Yaroslav Stetsko as the Head of the Regional Administration of the Western Regions of Ukraine. We expect from his government wise and fair governance, which will recognize and unite the needs and good of everyone living in our land despite the nationality or social strata ${ }^{332}$.

330 Депортації. Західні землі України кінця 30-х - початку 50-х рр. Документи, матеріали, спогади. Т. І. Львів, 1996. С. 8-12; Popiński K., Kokurin A. Drogi śmierci. Ewakuacja więzień sowieckieh z kresów Wschodnich II Rzeczy pospolitej w czerwcu i lipcu 1941. Warszawa, 1995. S. 7-74, 98-104.

${ }^{331}$ ЦДІАУЛ. Ф. 201. ОП. 1. Cnp. 4342. Арк. 25-40.

332 Українське державотворення. Акт 30 червня 1941. Збірник документів і матеріалів. Львів; Київ, 2001. С. 126. 
It is clear that the UGCC defended the independent aspirations of the Ukrainian people. On July 5, 1941, Metropolitan A. Sheptytsky addressed one more pastoral letter to the believers and called: "All those who feel themselves Ukrainians and want to work for the good of Ukraine, let them forget about any party division, let them work in unity and agreement over the restoration of our economic, intellectual and cultural life so much destroyed by the Bolsheviks"333. The Metropolitan was elected as a chairman of the National Council (members - J. Slipyj, G. Kostelnyk) ${ }^{334}$. The Council was soon destroyed by the German occupation authorities, and the members of the government led by Y. Stetsko were arrested and sent to Sachsenhausen concentration camp.

Despite the statements of the Soviet historiography and official propaganda of the communist regime, the UGCC has never been a collaborator, moreover an ally of the Nazis. The announced gratitude to the German army for the liberation from the Bolshevik regime was conditioned by the ending of the mass repressions, deportations and the bloody massacre of the NKVD before their escape. The residents of the region met the Act of June 30, 1941 with great enthusiasm and new hopes. These feelings are also present in Metropolitan A. Sheptytsky's message to the clergy and the believers on July 5, 1941. Metropolitan expressed the hope that "on the foundations of solidarity and hard work of all Ukrainians, United Ukraine will rise not only as a great word and idea, but as a living, healthy, powerful state organism, established on the sacrifice of the lives of certain people, and by the anthill work, the iron efforts and hard work of the others" ${ }^{335}$.

At first, the German authorities were loyal to the church, in particular to the Greek Catholic Church, and did not interfere into the manifestation of the religious feelings of the occupied population, the restoration of the activities of organizations, religious publishers, and educational institutions. Thanks to flexible diplomacy and tireless work of the St. George's throne, the UGCC gained more power and made its contributions to national and cultural life.

\footnotetext{
333 Церква і суспільне питання. Львів, 1999. Т. 2. Кн. 2. С. 924.

334 Пилипів I. Українська греко-католицька церква в період німецької окупації (1941-1944 рр.). Галичина. 2002. № 8. С. 108-115.

335 ЦДІАУЛ. Ф. 358. Оп. 1. Спр. 11. Арк. 25.
} 
The loyal relationship between the UGCC and the occupying authorities escalated into a confrontation in the fall of 1941, when Berlin openly expressed its invasive intentions on Ukraine and launched terror on its occupied lands against national movements, in particular the OUN. In the first pastoral letter to the believers in December 1941, Metropolitan A. Sheptytsky condemned the repressions, the arbitrariness of the Nazis, and called Ukrainians to maintain their national dignity, to defend their freedom, their families and communities ${ }^{336}$. Later, in August 1942, in a letter to Pope Pius XII, he openly emphasized: "The German authorities are evil, almost devilish, and much worse than the Bolshevik authorities" ${ }^{\prime 337}$.

In the pastoral letters, addresses of Metropolitan and other hierarchs of the church, the main calls were made toward national unity and harmony, which they considered to be a prerequisite for building an independent and powerful Ukrainian state. This thought is dominant in the already mentioned Metropolitan's message of July 5, 1941. Andrey Sheptytsky clearly affirms that United Ukraine will be built only under the conditions of solidarity and tireless work of all Ukrainians. At the same time, believers were called for religious unity, which should become the spiritual platform for the unification of all national forces during the war ${ }^{338}$.

In the same period, on July 20, 1941, the Galician press published "Metropolitan's letter to the clergy on the organization of the parish and the community". This pastoral letter outlined the urgent tasks of the priests during that difficult period: "In the first place it is necessary to take care of families and the property of the believers arrested and deported by the Bolsheviks. Their families need help, which the pastor should be glad to give by himself and organize so that widows, orphans, or women and children who were left without care of their father and husband for a long time, they have the right to

336 Шептицький Андрей, митрополит. Як будувати рідну хату? Митрополит Андрей Шептицький. Матеріали та документи (1865-1944). 2-ге видання / За редакцією Заборовського Я.Ю. Львів; Івано-Франківськ: Олір, 1995. С. 70-104.

337 Береславський М.3. 3 історії Української греко-католицької церкви. Львів, 1992. С. 30.

338 Шептицький Андрей, митрополит. Послання до духовенства i вірних Архієпархії. Львівські єпархіяльні відомості. 1942. Ч. 1. С. 9. 
seek that care from the church" 339 . Public attention was also drawn to the need to restore the national schools, as well as the activities of public cultural and educational organizations and cooperatives and to organize local self-government.

Under the pressure of the German military administration, on July 25, 1941, Andrey Sheptytsky addressed to the harvesting farmers: "The team of the German army asks me to instruct the Highly respected clergy to announce to the people the proclamation of the German Economic Commission... The believers must be encouraged to work harder and more properly on their farm lands because it depends on their own future livelihood, covering all expenses and rebuilding the economy". However, in the end he also mentioned "the help to the German army through the sale of farm products to the so-called collection points" 340 .

There were some attempts to consolidate the right-wing Ukrainian politics. In August 1941, the first organizational meeting of representatives of the OUN of Bandera and Melnik directions was held in the Metropolitan Chambers with the participation of Andrey Sheptytsky and Josyf Slipyj. But it failed ${ }^{341}$. The unity was not achieved. With the assistance of Metropolitan, in 1942 negotiations were held in Lviv among the OUN and the representatives of the Polish underground. Unfortunately, coordination of military-political efforts against the Nazis was not achieved again ${ }^{342}$.

During that period, the UGCC was doing everything possible to support people on spiritual level, to preserve their high moral and ethical values. The priests called to maintain a Christian family life. The Church strongly condemned Nazis' terror and repressions as methods of political struggle. Metropolitan A. Sheptytsky expressed his negative approach to terror and repressions in his famous pastoral

\footnotetext{
339 Малик Я., Сурмач О. Преса про діяльність Української греко-католицької церкви в період німецької окупації. Українська періодика: історія і сучасність. Львів, 1999. С. 169-173.

${ }^{340}$ Ibid

341 Архів СБУ у Львівській області. Спр. П-32693 (Сліпий Й.). С. 44-45.

342 Потічний П. У ПА та німецька адміністрація. Зустрічі. 1991. № 2. С. 137-142.
} 
letter "Do not kill" (November 21, 1942). He warned that the curse of the church would fall on all who sheds innocent blood ${ }^{343}$.

The confrontation between the UGCC led by Metropolitan A. Sheptytsky and the Nazi regime manifested itself with the increasing terror in the occupied territories. In a letter to Pope Pius XII on August 31, 1942, he angrily wrote about mass executions of Jews in Ukraine. He referred condemning the genocide of the Jews directly to A. Hitler. Only the patronage of Governor-General G. Frank saved Metropolitan from arrest. According to the witnesses, A. Hitler noted that A. Sheptytsky should be hanged for such actions, but Metropolitan A. Sheptytsky can afford it. It is also important that Metropolitan hided in his chambers and saved from the deaths Rabbi Ezekiel Levi and 150 Jews in the monasteries ${ }^{344}$. In 1942, Andrey Sheptytsky appealed to the Reich Commissar H. Himmler protesting against the use of extra police units in the raids against Jews.

Special attention was provided to the education of the young generations. In July 1941, six kindergartens were opened in Lviv and Andrey Sheptytsky personally greeted children in St. George's Cathedral. On the initiative of the church, kindergartens were also established in the cities of Zolochiv, Zbarazh and other settlements. Metropolitan ordination was fighting against the propaganda of atheism and called priests to catechize students, encouraged young people to study crafts and trades, organized a fundraising to help high school and professional youth. Archbishop Josyf Slipyj and Fr. Dr. Havryil Kostelnyk repeatedly served the Holy Mess and memorial services for students - victims of Bolshevik and Nazi terror. "Metropolitan Andrey Sheptytsky People's Hospital" with 82 employees, including 17 doctors and 18 nuns, was reopened ${ }^{345}$.

343 Кравчук А. Християнська соціальна етика під час німецької окупації Галичини, 1941-1944: Митрополит Андрей (Шептицький) про солідарність, опір владі та захист святості життя. Ковчег. Львів, 2000. Ч. 2. С. 224-269.

344 Гайова О. Митрополит Галицький. Украйнський альманах 2001. Варшава, 2001. С. 103; Кравченюк О. Велетень до Святоюрської гори. Торонто, 1963. C. 103 .

345 Малик Я., Сурмач О. Преса про діяльність Української греко-католицької церкви в період німецької окупації. Українська періодика: історія і сучасність. Львів, 1999. С. 172; Дітвора своєму опікунові. Рідна земля. 1943. Ч. 35; Краківські вісті. 1942. Ч. 146, 262; 1943. Ч. 4; Львівські архієпархіальні відомості. 1942. Ч. 5. С. 93; Ч. 6. С. 131. 
The care about scientists also continued. The scientific collection of "OSBM Notes" has been restored. The diplomas of Doctor of Theology were re-registered. Metropolitan repeatedly had meetings with leading scientists from the cities of Kyiv, Kharkiv, Dnipropetrovsk $^{346}$.

The Church helped to save lives of 40,000 Red Army prisoners of the German concentration camps in the Metropolitanate's territories. UGCC helped to 25,000 children evacuated from Pokuttya region during the terrible floods and provided other charity actions. Greek Catholic parishes sheltered the fugitive-priests from eastern Ukraine. Orphanages were established and taken under the protectorate in the towns of Zbarazh, Zolochiv and in the village of Voinyliv in Stanislav region $^{347}$.

On November 18, 1941, Alfred Rosenberg sent the Reichscomissar for Ukraine Erich Koch secret instructions, which recommended that churches and sects should be banned from political activities and public statements. The bishops were not supposed to be representatives of the Ukrainian nation, but officials appointed by the Ministry of the Occupied Territories of the East. His new instructions, dated by May 13, 1942, required that religious communities could exist only if they were not engaged in politics and were not dangerous for the German authorities ${ }^{348}$. There was a similar Nazi policy towards the religious communities of the Galicia District, which was part of the General Governorate (established on October 12, 1939).

The Ukrainian Central Committee (established in 1940 in Krakow, headed by professor-geographer Volodymyr Kubiyovych) and its regional representative - Ukrainian Regional Committee in Lviv (existed until 1942) tried to control the socio-cultural, in particular church-religious, life of almost 4.3 million Greek Catholics ${ }^{349}$. The

\footnotetext{
346 Малик Я., Сурмач О. Преса про діяльність Української греко-католицької церкви в період німецької окупації. Українська періодика: історія і сучасність. Львів, 1999. С. 172.

347 Антонюк Н.В. Українське культурне життя в «Генеральній губернії» (19391941). Львів: Наукова бібліотека ім. Стефаника, 1997. С. 166; Державний архів Львівської області. Ф. 3, оп. 1, спр. 71, арк. 118.

348 Лисенко О. Церковне життя в Україні. 1943-1946 pp. Київ: Інститут історії України НАНУ, 1998. С. 13.

349 Антонюк Н. В. Українське культурне життя в «Генеральній губернії» (19391944 рр.). Львів, 1997. С. 16-28; Жуковський А., Субтельний О. Нарис історії 
clergy played a significant ideological and organizational role in the social activities of these political structures. In particular, almost all 32 UCC delegates in the Galicia district were in different periods headed by Greek Catholic priests Fr. Y. Pleshkevych Fr. M. Yuzvyak, Fr. S. Leshchynsky, Fr. Dean M. Rusyn, Fr. I. Hodunko ${ }^{350}$.

During the spring of 1940, an advisory Council for the Affairs of the Greek Catholic Church was established. This council was aimed to resolve the social and territorial-organizational problems that arose in connection with the new conditions of religious life. Representatives of the council provided material help to priestsUniates from the East, placed them in Greek Catholic parishes, searched for them a job places in secular institutions and asked for financial assistance from the government ${ }^{351}$.

The church repeatedly warned citizens from unwise actions, called to be politically restrained and not to be involved into interethnic provocations by the Nazis and Polish chauvinists and rebel leaders ${ }^{352}$. The warning came from the general guidelines of the church, which at the period of the devastation of human souls and the devaluation of human life actively opposed the most terrible sin - human killing. This issue was discussed at the third and fourth archdiocesan councils of $1942-1943^{353}$. The fifth council of 1944 once again drew the attention of the people to the struggle against disagreements, hostility and hatred among the nations, which "in the storm of war, only grows" 354 .

України. Львів, 1992. С. 117; Кубійович В. Українці в Генеральній Губернії. 1939-1941. Історія Українського Центрального Комітету. Чикаго, 1975. С. 3-12; Шаблій О. Володимир Кубійович: Енциклопедія життя і творення. Париж; Львів, 1996. 704 с.; ЦДІАУЛ. Ф. 408. Оп. 1. Спр. 631. Арк. 2-8.

350 Лисенко О. Церковне життя в Україні. 1943-1946 pр. Київ: Інститут історії України НАНУ, 1998. С. 21.

351 Антонюк Н. В. Українське культурне життя в «Генеральній губернії» (19391944 рр.). Львів, 1997. С. 157.

352 Слово Митрополита. Краківські вісті. 1943. Ч. 179; Послання Всепреосв. Митрополита Кир. Андрея до Духовенства і вірних. Львівські архієпархіяльні відомості. 1943. Ч. 8/9. С. 109-110.

${ }^{353}$ Антонюк Н. В. Українське культурне життя в «Генеральній губернії» (19391944 рр.). Львів, 1997. С. 164-165; Львівські архієпархіяльні відомості. 1942. Ч. 12. С. 205- 208; 1943. №6/7. С. 85-88. Ч. 8-9. С. 109-110.

354 Львівські архієпархіяльні відомості. 1944. Ч. 1/3. С. 3. 
The UGCC used all possible ways to revive the religious life, as well as to legally lead the spiritual life of the people and promote their national and cultural development. In 1943, the Church Archaeographic Commission was established as a center for the objective research of the history of Ukrainian churches. This commission united well-known scientists Ivan Krypiakevych, Dmytro Doroshenko, Oleksandr Ohloblyn and others ${ }^{355}$. However, they were not able to develop large-scale work.

The hierarchy of the Greek Catholic Church tried to have a dialogue with the Ukrainian Autocephalous Orthodox Church and the Autonomous Orthodox Church, which operated in the western region during World War II. It should be noted that not only in Galicia, but also in the Dnieper Ukraine, the Germans quite calmly welcomed the revival of the Ukrainian Orthodox Church ${ }^{356}$. The occupation authorities returned the temples and monasteries to the believers, which were confiscated by the Stalin regime. The authorities also allowed the resumption of the UAOC, destroyed by the Bolsheviks, headed by Archbishop P. Sikorsky, and the development of the church structures of other denominations, educational institutions, and publishers that published religious literature. Archival documents show that the Soviet government was well-informed and had all detail information about the church policy of Berlin on the occupied territories, which caused discomposure for Stalin and forced him to take urgent measures.

In the fall of 1943, the Kremlin leaders radically changed their church policies. Some additional factors that are important in the context of war actions caused this situation. The war testified to the low morale and political spirit of the army, destroyed by violent collectivization, famine, mass repressions and terror by the Stalinist regime against its own people. As a consequence, the millions of soldiers and commanders of the Red Army were captured during the first months of the war. There were hard military defeats, and a million of Soviet people joined the ranks of the Wehrmacht and the police. In order to uplift the moral and political spirit of the army and the people, Stalin had to forget about some communist postulates like

355 Логос. 1995. Т. 4. Кн. 3. С. 135-147.

356 Центральний державний архів громадських об'єднань України (ЦДАГО України). Ф. 1. Оп. 23. Спр. 45. Арк. 16. 
"religion is the opium of the people" and to reconsider the attitude towards religion and the church. The allies - members of the antiHitler coalition: The United States, England, France also played important role. The allies-states did not accept Moscow's brutal attitude towards religion because of violation of the human rights declared by the Constitution and acts of the League of Nations.

On September 4, 1943, for the first time in 20 years, there was a meeting of the head of the Soviet state, J. Stalin, with the hierarchs of the Russian Orthodox Church, who, headed by Metropolitan Sergey, survived in the horrific repressions. Important decisions were adopted on the support of the church by the state: the call of the Council, the opening of temples and spiritual educational institutions, the increasing of rights and freedoms of religious communities, the release from prisons and concentration camps of the repressed church leaders. The Council for ROC Affairs was established under the Soviet People's Commissar. Stalin appointed NKVD Colonel G. Karpov as a chairman of the council ${ }^{357}$. Undoubtedly, the main purpose of the "religious revival" in the USSR, initiated by Stalin during the war, was to use the church and its authority among compatriots to implement pragmatic political and ideological plans in the country and beyond. The communist regime had never allowed the church to participate in the ideological sphere of society, in the education of the Soviet people.

The communist leaders of Moscow and Kyiv have already developed a specific attitude towards the Ukrainian Greek Catholic Church. It was associated with "Ukrainian bourgeois nationalism" because it remained a source of the Ukrainian national idea, an effective factor in the formation of the consciousness of Western Ukrainians. Moscow considered the UGCC as a collaborator, arguing that all 32 Galicia district delegates were headed by Uniate priests. The other argument was that the church participated in the formation of the Ukrainian division "Galicia" within the Wehrmacht,

357 «Русская православная церковь стала на правильный путь». Докладные записки председателя Совета по делам Русской православной церкви при СНК СССР Г.Г. Карпова И.В. Сталину 1943-1946 гг. Исторический Архив. 1994. Т. 3. C. $139-148$. 
maintained contacts with the German administration, and at the same time assisted the "Bandera followers"

There was a department of spiritual guardianship under the Military Administration of the "Galicia" Division. It was headed by the Vice-Rector of the Lviv Theological Seminary, Professor of the Lviv Theological Academy, Doctor of Theology Vasyl Laba, who signed the official documents as the "Referent of the Pastoral Office under the Main Directorate of the "Galicia" Division"359. On the request of Bishop Hryhori Khomyshyn, at the beginning of July, 1943, on the square in Stanislaviv the future soldiers of the division were blessed by Bishop Ivan Lyatyshevsky, a leader of the Ukrainian national bulletin "Nova Zoria", and by several priests. In April 1945, this fact became the basis for the arrest and numerous interrogations of a leader of the "nationalist organizations" and, consequently, his exile to the Jambul region of Kazakhstan ${ }^{360}$.

As for Bandera movement, throughout the Nazi occupation period, Greek Catholic priests not only actively worked in the fields of culture and education, took care of the spiritual status of the believers, but also aided the Ukrainian resistance movement represented by OUN and the UPA. Monasteries and churches were the spiritual and material support for the rebels and underground in their struggle against the Nazis, and later against the Stalinist regimes. Based on the principles of Christian morality, the Metropolitan Consistory forbade the clergy to engage in the armed struggle. However, it was closely connected with the people and did not stand apart from the tragedy of the land. The monasteries assisted the wounded UPA soldiers. In the Monastery in the village Uhniv, Peremyshliany district in the Lviv region, an underground hospital for the ill rebels was operating ${ }^{361}$.

The contacts between insurgents and Ukrainian authorities in the eastern Ukraine maintained. The Ukrainian National Council (established on October 5, 1941 in Kyiv with the participation of the OUN-M) tried to harmonize both church-religious and national life. To this aim, the Ukrainian Church Council was formed, which in

\footnotetext{
${ }^{358}$ Боляновський А. Дивізія «Галичина». Історія. Львів, 2001. С. 118-127.

${ }^{359}$ Ibid. C. 44-45.

${ }^{360}$ Соколовський О. Слуга Божий Спископ Кир Іван Лятишевський: хронологія останніх років земних скитань. Нова зоря. 1993. Вересень. Ч. 33-34.

361 ДАЛО. Ф. 3. Оп. 1. Спр. 436. Арк. 148.
} 
early 1942 decided to ask A. Sheptytsky to become a Patriarch of the UAOC. It is well known that the revived autocephalous eparchies were extremely poor - both financially (lacking church utensils, liturgical books) and organizationally (lacking staff, educational institutions). This request was formally presented to Metropolitan in April in Lviv by Fr. J. Kladochny ${ }^{362}$. However, the proposal was not accepted. At the same time, Metropolitan A. Sheptytsky did not refuse assistance to the autocephalists, noting that "those not-united, who will accept the Catholic faith, do not renounce the Orthodox faith, but supplement it with the doctrine of the Catholic Church, the united thought" ${ }^{363}$.

Already mentioned Joseph Kladochnyi maintained in Kyiv the relations with the head of the Ukrainian National Council M. Velychkivsky, the mayor of the city of Kyiv, prof. V. Bagaziy, deputy chairman of the Leadership of the Ukrainian Nationalists, archaeologist and poet O. Olzhych-Kandyba, Ukrainian leader of the Kuban region in 1917-1921, S. Manchula. Together with Fr. J. Kladochnyi, a catholic pastor Yuri Protsyuk was engaged in pastoral activity in the capital. In 1941-1942, Greek Catholic parishes were established for tens of thousands of Galicians living in the cities of Kamianets-Podilskyi, Proskuriv, Vinnytsia, Zhytomyr, and even Chernihiv $^{364}$.

Unfortunately, the leadership of the church failed to make agreement with the command of the Army Craiova, whose militants inflicted many grievances on individual parishes and patriotic laymen not only in Zakerzonia and Volyn, but also in Galicia ${ }^{365}$.

However, the church leadership tried to get in touch with the restored Soviet authorities in the fall of 1944. In October, seriously ill Andrey Sheptytsky sent a letter to the Council on Religious Affairs under the USSR government. However, Metropolitan died on November 1, 1944, in the middle of his actions to protect the church in a new situation. His majestic funeral in Lviv, to which Khrushchev arrived with a wreath from Stalin, turned into a demonstration of the

362 Шкраб'юк П. Виноградник Господній; Історія життя о. д-ра Йосифа Кладочного. С. 167-168.

363 Ibid.

${ }^{364}$ Ibid. C. 168-170.

${ }^{365}$ Каспришин Р. Іродів ніколи не бракувало. Місіонар. 2001. № 2. С. 57. 
power of the Greek Catholic Church in the western region. The Metropolitan throne was occupied by Josyf Slipyj, who in November congratulated the "liberators" and in December 1944 sent to Moscow a venerable delegation of Greek Catholic hierarchs, led by Archimandrite Klymentiy Sheptytsky. The delegation was received by the Council on Religions under the Government of the USSR. During the negotiations, the head of the commission conveyed the letter of Metropolitan to Stalin ${ }^{366}$. Another letter to the Government substantiated the request not to interfere with the activities of the UGCC. The delegation also donated 100 thousand rubles to the Red Cross Fund. After consulting with V. Molotov and M. Khrushchev, Chairman of the Council, Colonel I. Poliansky, on behalf of the Soviet leadership, stated that the Ukrainian Catholic Church has equal rights with other denominations operating in the USSR and may operate within the framework of existing legislation. It is clear that I. Polyansky informed Stalin in detail about the course of the five-day negotiations (December 22-27, 1944). Obviously, in connection with the war, the "leader of the nations" did not want to engage in open conflict with the UGCC ${ }^{367}$.

During the offensive of the Soviet army in Lviv, in July 1945, the OUN and the UPA distributed a leaflet "Ukrainian Greek Catholics" with the warning: "Let all the traitors and werewolves understand that while we, the Ukrainian rebels, are walking in the world, until then all the Stalin agents and ministers who help the Bolsheviks to lay the yoke on the neck of the peoples will be taught our insurgent custom, no matter who it is ${ }^{, 368}$. It is clear that the church hierarchy tried to avoid the mass bloodshed in the region, which was criticized by some rebel commanders.

In the 1940s-1950s, 200 priests of the Stanislav eparchy were repressed for the support of the "bourgeois nationalism". The spiritual bishops, who conveyed their pastoral messages to them even from a

\footnotetext{
366 Одинцов М.И. Путь длиною в семь десятилетий от конфронтации к сотрудничеству: государственно-церковные отношения в истории советского общества. На пути к свободе совести. Москва, 1991. С. 64; ЦДАГО України. Ф. 1. Оп. 23. Спр. 1638. Арк. 17-18.

367 Білас I. Репресивно-каральна система в Україні 1917-1953. Кн. 1. Київ: Либідь - Військо України, 1994. С. 310.

368 Сергійчук В. Нескорена церква: подвижництво греко-католиків України в боротьбі за віру і державу. Київ, 2001. С. 72-75.
} 
distant Siberian exile, did not leave their faithful in this difficult time, asking "to maintain their parental faith, their native fatherland, their churches and their homes, their language and God's truth"369.

So, after the liberation of the western region from the Nazi invaders, a new phase in the history of the church begins. The change in Stalin's course on religion during the war (1943) marked the transition of authorities from fierce confrontation to a more flexible policy on the church and the believers. The reasons for switching to partnership mode were not in the attempts to democratize the regime, but in the desire to camouflage its repressive nature, to suppress the image of a post-war "socialist" society in the eyes of the world public. However, in the early postwar years, many believers and some of the clergy were repressed. It is important that according to court sentences, they were not punished for pastoral activity, but as "enemies of the people". At the same time, the clergy and believers were constantly under the control of the state security agencies, who sought to turn the "separate" church into tools for strengthening of the totalitarian regime in the new regions of the UkrSSR.

Some sort of tolerance of the Soviet power to the church did not last long: in 1946 the regime organized a Lviv "council", which in fact drove the UGCC into the underground, which lasted until the end of the $1980 \mathrm{~s}^{370}$. The forced confessional-institutional transformation of the region's largest church was caused not so much by military and political circumstances as by the arguments of the strategic plan - by the need to neutralize the patriotical priesthood, which did not accept communist social ideals, politics of the Sovietization, and which spiritually supported the Ukrainian rebels.

\footnotetext{
${ }^{369}$ Ibid. C. 27.

370 Лисенко О.Є. Церковне життя в Україні. 1943-1946 pp. Київ, 1998. С. 245-363; Ковчег. Львів, 2002. Ч. 2. С. 165-188.
} 
DOI https://doi.org/10.36059/978-966-397-213-8/122-152

\section{PART 5. THE SUFFERING PATH OF THE CHURCH IN THE SECOND HALF OF THE 1940s - 1980s}

The activities of the Initiative Group gave reasons to the state security authorities to move to the next stage of implementation of the general plan for the liquidation of the UGCC. In September 1945, the National Security Service of the UkrSSR developed appropriate measures to accelerate the process of transition of the Uniate priests to the Orthodox Church. It was planned to hold diocesan congresses at which this issue would be agreed in the dioceses. However, the rejection of such an idea by a large part of the priests, and by G. Kostelnyk himself, forced the Chekists to take into account the specificity of the canon law.

In December 1945, at the NCSD of UkrSSR, it was decided to prepare the General Church Council of the UGCC (the Galician Council) as "the only canonical form of organizational consolidation of the liquidation of the Greek Catholic Church and its reunification with the Orthodox Church". As stated in the corresponding letter of S. Savchenko to V. Merkulov, the convening of such a "council will be the most sensual blow to the Vatican, ...it will break the ground of the "nationalist bandit underground of the OUN and other terrorist groups and will create preconditions for the use of Uniate priests in the Orthodoxy for religious and patriotic work in the western regions of Ukraine". People's Commissar S. Savchenko assured that the opportunities of the authorities at that time "fully guarantee the holding of the "Galician Council" in the desirable for us direction", and asked to allocate 500,000 rubles for these events. At the end of January 1946 a telegram came from V. Merkulov, which reported about the permission to hold a church council, allocation of over 400 thousand rubles to ensure this event, as well as the recommendation to avoid the name of council as "Galician"371.

371 Ліквідація УГКЦ (1939-1946): документи радянських органів державної безпеки. К.: ПП Сергійчук М.I., 2006. Т. 2. С. 497-498. 
Appropriate measures were also carried out by the Soviet authorities. In mid-December 1945, in Kyiv, a joint meeting of the Commissioners of the Council of the ROC and the RSRK took place at the regional executive committees of the western Ukrainian regions, in which, in addition to the republican heads of these structures P. Khodchenko and P. Vilkhovyi, Moscow leaders G. Karpov and I. Polyansky also participated. This meeting outlined a general approach to the organization and holding of the council. The meeting was followed by another in a narrow circle, which discussed the readiness to convene a "council of representatives of the Greek Catholic clergy to formally approve and announce the act of breaking with the Vatican and reuniting with the Russian Orthodox Church",372. After this meeting, G. Karpov and I. Polyansky attended a reception at the chair of the UkrSSR, M. Khrushchev and his deputy L. Korniets, where, according to P. Khodchenko, approved the measures for the preparation of the council.

In the process of elaborating this problem, the chronological boundaries for the implementation of this event were determined the first decade of March 1946, which was dedicated to the so-called "Orthodoxy Week". Thus, the holding of the council by the authorities of the UGCC priests pursued the aim of legalizing by church and canon law the actual state of the church's defeat, which was carried out at that time by the active methods of the authorities and the repressive bodies.

The structures of the NSCD have formed an extensive intelligence network for the systematic secret collection of information regarding the UGCC. In order to prevent any unforeseen actions, numerous arrests have been made among the Greek Catholic clergy. During the period of restoration of the Soviet authorities (from the summer of 1944 to March 1946), 287 people were arrested "on the Uniate line", including 1 metropolitan, 4 bishops, 182 priests, 11 monastery chairmen, 6 deacons, 23 monks, 9 students of theological academy and other believers connected with the activities of the nationalist underground or units of the $\mathrm{UPA}^{373}$. Under the jurisdiction of the

\footnotetext{
372 ЦДАГО України. Ф. 1. Оп. 23. Спр. 1639. Арк. 149-150.

373 Ліквідація УГКЦ (1939-1946): документи радянських органів державної безпеки. К.: ПП Сергійчук M.I., 2006. T. 2. С. 518.
} 
G. Kostelnyk Initiative Group, 1805 parishes led by their pastors were replaced by administrative methods. Often, written commitment was obtained through "individual processing" and during the clergy meetings.

Thus, from the organizational point of view of the Soviet authorities, the necessary preconditions were created for holding a council at which the expected decisions had to be adopted. To deprive any possibility of avoiding direct or indirect participation in the planned action, the authorities once again went on a demonstrative intimidation. On March 1, 1946, in the newspapers of the western regions of Ukraine, a message from the Prosecutor of the UkrSSR R. Rudenko was published about the charges of the hierarchs of the church arrested in 1945 (J. Slipyj, G. Khomyshyn, M. Charnetsky, M. Budka, I. Lyatyshevsky, and others.) $)^{374}$. The arrested were accused of active cooperation with the German authorities, assistance in the "armed struggle of the German invaders against the Red Army", "their participation in the formation of the SS division "Galicia" to fight the guerrilla movement and the Red Army". Such allegations came under the qualification of Articles 54-I and 54-II of the Criminal Code of the UkrSSR - "betrayal of the motherland, that is, actions committed by citizens of the USSR to the detriment of the military strength of the USSR, its state independence, namely: espionage, extradition of military or state secrets, moving to the side of the enemy, escape or flight abroad", for which a higher punishment was assumed - execution with confiscation of property, and in mitigating circumstances - 10 years' imprisonment also with confiscation of property.

However, in the message to the Central Committee of the Communist Party (b) the secretary of the Lviv Party Committee I. Hrushetsky noted that a significant part of believers met the message of the Prosecutor of the UkrSSR, as well as the news about the church council ambiguously, in most of the documents cited as negatively ${ }^{375}$.

\footnotetext{
374 Гайковський М.І.Хресною дорогою: Функціонування і спроби ліквідації Української Греко-Католицької Церкви в умовах СРСР у 1939-1941 та 19441946 роках: збірник документів і матеріалів/ упоряд.: Гайковський М.І. Львів: Місіонер, 2006. С. 330.

375 ДАЛО. Ф. П-3. Спр. 424. Арк. 48-51.
} 
In order to increase the level of representation of clergy at the council, it was decided to consecrate several of them as bishops. Representatives of the Council on Religious Affairs and ROC under the Government of UkrSSR P. Hodchenko and P. Vilkhovy in the letters to Moscow Patriarch Alexey and the Exarch of Ukraine Ioann, proposed to nominate and immediately consecrate at least two bishops among the Uniate priests. Among the most likely priests the most acceptable candidates were the members of the Initiative Group M. Melnyk and A. Pelvetsky, who proved themselves to be reliable leaders of the policy of the Soviet authorities and were supported by G. Kostelnyk ${ }^{376}$.

To fulfill this requirement, on the submission of the Initiative Group, according to the characteristic of the secretary of the Initiative Group S. Khrutsky, there had been selected ten the "most prominent and authoritative" Greek Catholic priests, who went to Kyiv. On February 22, they took part in a solemn liturgy celebrated by the Metropolitan of Kyiv and Galicia, Exarch of Ukraine Ioann. After that, A. Pelvetsky and M. Melnyk were consecrated in monastic order. On the same day, during the evening Mass at the Volodymyr Cathedral, with the participation of the senior hierarchs of the Ukrainian exarchate of the ROC, the act of appointing candidates for bishops took place, and on February 24-25, an ordination (consecration) of A. Pelvetsky and M. Melnyk was held. The first was appointed as bishop of Stanislav Eparchy, and the second as the bishop of Sambir-Drohobych Eparchy of ROC ${ }^{377}$.

The Soviet authorities, by all possible means, facilitated the activities of the newly ordained Orthodox bishops. Thus, after the formation of the Stanislav Orthodox Eparchy within the administrative-territorial areas at the regional executive committee, there officially was established a department for the affairs of the Russian Orthodox Church $^{378}$. At that time, the Orthodox Eparchy of

${ }^{376}$ ЦДАГО України. Ф-1. Спр.1638. Арк. 130-135.

377 Гайковський М.І.Хресною дорогою: Функціонування і спроби ліквідації Української Греко-Католицької Церкви в умовах СРСР у 1939-1941 та 19441946 роках: збірник документів і матеріалів/ упоряд.: Гайковський М.І. Львів: Місіонер, 2006. С. 324-326.

378 ДАІФО. Ф. Р-389. Спр. 3. Арк. 9. 
the ROC consisted of only four officially registered parishes in the cities of Stanislav, Halych, Snyatyn and Kolomya ${ }^{379}$.

After solving the task of providing the council with the bishops' presence, the authorities worked out the agenda of the council and a clear plan for its holding. On the eve of the council on March 6, 1946, a meeting of 18 priests was held at the apartment of the head of the Initiative Group G. Kostelnyk. Among the topics of the speeches there were: motives for reunification of the Greek Catholic Church with the Russian Orthodox Church; church issues related to turning to the Orthodox Church; territorial division of eparchies and deaneries according to the state administrative division into regions and districts $^{380}$.

The Soviet authorities closely monitored both the preparations for the council and its course. Since the beginning of March, Karpov communicated daily with Kyiv and Lviv, sending instructions and recommendations, and requesting regular updates on the progress of the council ${ }^{381}$. G. Karpov gave instructions to a delegate to Lviv, Utkin, and a local SRRS commissioner in the Lviv region, Vyshnevsky, to inform him every day from March 5 to March 10 on the events ${ }^{382}$.

Colonel S. Karin together with Captain O. Bogdanov, carried out direct organization of the relevant events on the line of the National Security and Defense Council and were responsible for holding the arrival and accommodation of the participants, giving food stamps, general protection of the place of the church meeting - St. George's Cathedral and hotels where the delegates settled. General coordination of activities, related to the plan, was carried out by the Deputy Commissar of the National Security Service of the UkrSSR, Lieutenant General P. Drozdetsky ${ }^{383}$.

\footnotetext{
379 Ibid

${ }^{380}$ ДАІФО. Ф. Р-389. Спр. 3. Арк. 5.

381 Білас І.Г. Репресивно-каральна система в Україні. 1917-1953: Суспільнополітичний та історико-правовий аналіз. Кн.2: Документи і матеріали. К.: Либідь - Військо України, 1994. С. 300.

382 Ibid. C. 301.

383 Сердюк Н.С. Репресії радянських органів державної безпеки щодо Української греко-католицької церкви в 1944-1949 рр.: автореф. дис. на здобуття наук. ступеня канд. іст. наук: спец. 07.00.01 «Історія України». К., 2006. С. 14.
} 
The authorities provided not only ideological and organizational but also financial support for the action to eliminate the UGCC. According to the order of the RNA of the USSR from January 24, 1946, signed by V. Molotov, there were allocated 400 thousand rubles from the government reserve fund for various expenses associated with the council ${ }^{384}$.

Scientific literature contains controversial information about the number of Greek Catholic priests who supported the Initiative Group on the eve of the council. A. Pelvetsky in his speech at the council said that 986 priests joined the Initiative Group and 281 clergymen $^{385}$ did not support its activity, which means the total number of priests was 1267. According to the Ukrainian researcher O. Utkin, the Initiative Group had an influence on 997 and general number of the priests was 1,270. The research of the Russian researcher D. Pospelovsky states that there were 2000 Greek-Catholic priests in total, but at the time of the council there were not imprisoned $1297^{386}$, and 997 supported "reunification" with the ROC ${ }^{387}$.

Undoubtedly, the accuracy of all these calculations is sufficiently conditional, mainly taken from the Soviet sources, as indicated by V. Sergiychuk. According to the data given by him, in December 1945, there were 2,286 Greek Catholic communities ${ }^{388}$ in four Galicia regions. That means that even the part of the priests who in fact were engaged in spiritual activity could not fully provide the pastoral mission in these communities.

According to the council's mandate commission, there were invited 225 delegates-priests - members of the Initiative Group and 22 delegates from laymen from three Greek-Catholic eparchies (Lviv, Sambir-Drohobych and Stanislav), 216 priests and 19 lay people

384 ДАЛО. Ф. Р-1332. Оп. 1т. Спр. 4. Арк. 20-23.

385 Діяння Собору УГКЦ 8-10 березня 1946 р. Львів: Видання Президії Собору, 1946. С. 61.

386 Уткін О. Львівський церковний собор 1946 р. в контексті тогочасних політичних реалій. Украӥнський історичний журнал. 1998. № 5. С. 109.

387 Поспеловский Д. Православная церковь в истории Руси, России и СССР: учеб. пособ. М.: Библейско-богословский институт Св. Апостола Андрея, 1996. С. 218.

388 Сергійчук В. Греко-католицька церква в 1944-1991 pp. Український історичний журнал. 1996. № 4. С. 112. 
arrived. The invited priests who did not join the Initiative Group, refused to participate in the council. According to J.Herych, the number of participants was much smaller than that presented by the mandate commission and A. Pelvetsky, and did not exceed 140 people $^{389}$.

On the morning of March 8, 1946, the Lviv Council began its work. The procedure of this action in a sublime and commendable tone was transmitted in the edition of the "Actions of the UGCC Council on March 8-10, 1946 in Lviv", issued immediately after its completion $^{390}$. The first reporter on the activities of the Initiative Group was the bishop of the Russian Orthodox Church A. Pelvetsky. In his report, he outlined the purpose of the work of the Council: "Before the normalization of church life, only the Council can open the door to us, which will confirm our return to the Orthodox Church",391.

After that, A. Pelvetsky, G. Kostelnyk made a report on the motives for reunification of the Greek Catholic Church with the Russian Orthodox Church. The main report of the council G. Kostelnyk began with the history of the Union, trying to convince the audience that Rome systematically and consistently used the Union of Brest to absorb Orthodoxy ${ }^{392}$.

The basis of G. Kostelnyk's report was the provisions set out in letters to the RNA and priests in May 1945. After his speech, a "discussion" began, in which pre-determined co-reporters with edited texts took part. All of them were in support of the proposals of the narrators A. Pelvetsky and G. Kostelnyk.

After that, it was proposed to proceed to the voting procedure. It took place in an open mode, with a rising of hands, with the voting

389 Герич Ю. Як відбувався «возсоєдинительний собор» у Львові 8 березня 1946 р. Календар «Світла». Торонто; Нью-Йорк, 1995. С. 88.

390 Діяння Собору УГКЦ 8-10 березня 1946 р. Львів: Видання Президії Собору, 1946. С. 35 .

391 Гайковський М.I. Хресною дорогою: Функціонування і спроби ліквідації Української Греко-Католицької Церкви в умовах СРСР у 1939-1941 та 19441946 роках: збірник документів і матеріалів / упоряд.: Гайковський М.І. Львів: Місіонер, 2006. 650 c.

392 Львівський церковний собор: документи і матеріали. 1946-1981. К., 1984. C. 65 . 
being watched by both the staff of the National Security and Defense Agency and the cinema lenses that filmed the "historical council" for the newsreel. Accordingly, the delegates unanimously supported the draft of the decision in four points: "1) to annul the Brest Union regulations of 1596 ; 2) to break away from the Roman (papal) Church; 3) to return to the Orthodox faith of the predecessors; 4) to reunite with the All-Orthodox Church in the Soviet Union"393. Further, several documents were unanimously adopted ${ }^{394}$. The main document was the resolution of the council ${ }^{395}$.

Although the council was no longer deciding the fate of the UGCC, since at that time it was essentially defeated, its decisions allegedly legitimized the process. Therefore, the main planned task of the council was fulfilled on the first day of its work ${ }^{396}$.

The next day, March 9, the process of church-canonical registration of the transition to Orthodoxy took place. In the St. George's Cathedral, 12 priests, who reunited with the ROC in Kyiv in February 1946, were confessed. The council considered the issue of "canonical registration", the decision on "reunification", and during the joint liturgy conducted by Bishops Makariy, Antonyi and Mykhail, bishop Makariy fulfilled the act of "joining to the Orthodox Church", after accepting the refusal of Catholicism by the 204 delegate priests. After the liturgy, a memorial service for the peace of the soul of Metropolitan A. Sheptytsky took place immediately, which, after the attacks on his name by the authorities, could be regarded as a concession by the organizers of the council to these "reunited" priests to appease their conscience.

After the liturgy, the council continued its work. In particular, a number of appeals and greeting telegrams were approved. The "Address of the Council to the Clergy and Believers of the Greek

\footnotetext{
${ }^{393}$ Ibid. C. 75.

394 Герич Ю. Як відбувався «возсоєдинительний собор» у Львові 8 березня 1946 р. Календар «Світла». Торонто; Нью-Йорк, 1995. С. 256-257.

395 Львівський церковний собор: документи і матеріали. 1946-1981. К., 1984. С. 127-128.

396 Гайковський М.І. Хресною дорогою: Функціонування і спроби ліквідації Української Греко-Католицької Церкви в умовах СРСР у 1939-1941 та 19441946 роках: збірник документів і матеріалів / упоряд.: Гайковський М.І. Львів: Місіонер, 2006. С. 364-365.
} 
Catholic Church in the Western Regions of Ukraine" gave reasons for the elimination of the Union of Brest in 1596, the break with the Vatican, and reunification with the Orthodox Church. In an address to the Patriarch Alexy of Moscow and All Russia, the delegates requested "to recognize our resolution and to accept us to the AllRussian Orthodox Church", certifying it with their signatures ${ }^{397}$.

Finally, the participants of the council approved changes in church-administrative, marriage, liturgical practices. From now on, the eparchy operated within the existing regional administrative division. The final part of the work of the council was occupied by a ceremony with the participation of the Metropolitan of Kyiv and Galician, Exarch of Ukraine Ioann. G. Kostelnyk in favor of Metropolitan resigned as the head of the Initiative Group, as such, who had fulfilled its task. Metropolitan read a letter of congratulation from the Patriarch of Moscow, in which the Greek Catholic Church was accepted to the Orthodox Church and handed it to G. Kostelnyk ${ }^{398}$.

Addressing the participants of the council, Metropolitan Ioann expressed a clear desire of the Moscow Patriarchate to subordinate the UGCC, to strengthen greatly themselves and their influence on the believers. "I pray with all my heart," he urged, "that the present triumph should be the beginning of the complete elimination of the Uniate in our country, and then Christians, not only of the whole of Ukraine but of our Union, will form one bonded family of love, one flock under the control of a single shepherd - the holy patriarch of Moscow" 399 .

On March 10, in the St. George's Cathedral the church service was held with the participation of guests, other ceremonies and a joint dinner at the restaurant of the "Bristol" Hotel. After that, the delegates left for their homes ${ }^{400}$.

\footnotetext{
397 Діяння Собору УГКЦ 8-10 березня 1946 р. Львів: Видання Президії Собору, 1946. С. $133,137-139,141-145$.

398 Діяння Собору УГКЦ 8-10 березня 1946 р. Львів: Видання Президії Собору, 1946. C. $118-122$.

399 Ibid. C. 125.

400 Гайковський М.І.Хресною дорогою: Функціонування і спроби ліквідації Української Греко-Католицької Церкви в умовах СРСР у 1939-1941 та 19441946 роках: збірник документів і матеріалів / упоряд.: Гайковський М.І. Львів: Місіонер, 2006. С. 365-366.
} 
At the beginning of April 1946, members of the former Initiative Group, G. Kostelnyk, M. Melnyk and A. Pelvetsky arrived in Kyiv, where they met with M. Khrushchev and M. Grechukha. They gave the documents approved by the Lviv Council to the leaders of the UkrSSR, had a conversation about bringing the decisions of the council to the masses, and about the publication of the book "Actions of the Lviv Council’"401.

On April 4, the Lviv delegation arrived in Moscow, where it was received by Patriarch Alexy. They read and gave him a petition for joining the Orthodox Church. Subsequently, the delegation attended a wide reception hosted by G. Karpov for Patriarch Alexy, Metropolitan Ioann and members of the Lviv delegation headed by G. Kostelnyk. At the same time, instructions signed by G. Karpov for the registration of priests and parishes were sent to places in connection with the "reunification" of the Greek Catholic Church with the ROC, which regulated the procedure for registration, indicating that the "reunited" priests and deacons, as well as congregations (communities) must be registered immediately ${ }^{402}$.

In Moscow, the members of the delegation in the interview to a TARS correspondent substantiated not only the church-canonical but also the political and ideological grounds. The impersonal answers to the questions were more indicative of the editorial style of the district party ideology instructor than of the clergy ${ }^{403}$. After the trip to Kyiv and Moscow, the practical mission of the members of the former Initiative Group was completed.

Despite the decisions of the Lviv Council, a significant number of Greek Catholic priests continued to actively and passively resist the measures taken by the Soviet authorities to completely eliminate the UGCC. In April 1946, a special message from the chief of the Lviv Regional Office of the NKVD, Voronin, to the higher authorities indicated numerous examples of the negative reaction of Greek

401 Пащенко В. Греко-католики в Україні (від 40-х років XX століття до наших днів). Полтава, 2002. С. 218.

402 ДАЛО. Ф. Р-1332. Оп. 1т. Спр. 5. Арк. 9.

403 Львівський церковний собор: документи і матеріали. 1946-1981. К., 1984.

C. 98-99. 
Catholic priests to the council and its decisions, their willingness to continue their religious activities in the Uniate rite.

It should be noted that the UPA command and the leadership of the OUN underground supported resistance to the violent annexation of the UGCC to Orthodoxy. They conducted widespread outreach activities, exerted moral pressure on the clergy, which was subject to government pressure. However, there have also been cases of murders of priests who converted to Orthodoxy ${ }^{404}$. According to the official authorities, by the end of 1946, in the Stanislaviv region, in the face of fear of possible reprisal by the UPA, 22 priests abandoned the transition to Orthodoxy and terminated their duties to the Initiative Group. In the Ternopil region, 55 Greek Catholic priests motivated their refusal by the fear of possible repression by the nationalist underground ${ }^{405}$.

Despite the pressure from the authorities and the new church leadership, some priests and believers in the UGCC have refused to convert to Orthodoxy ${ }^{406}$. In total, by the end of 1946,1111 or $43 \%$ of the Greek Catholic priests had moved to the ROC, including 532 from the Lviv Eparchy, 203 from Przemysl, and 277 from Stanislaviv. According to I. Bilas, as a result of the mass arrests, at least 1,600 priests were sent in prisons and camps, and several hundred went on to illegal status, many of them continued pastoral service $^{407}$.

Thus, in 1946, the Council of Lviv did not become a moment of decisive turning of the Uniate clergy and faithful to Orthodoxy, as was expected by the Soviet government and the ROC hierarchs. It was only one of the stages of the process of liquidation of the Greek Catholic Church, an integral part of the anti-union policy of the

\footnotetext{
404 Лисенко О. Церковне життя в Україні. 1943-1946 pp. К.: Інститут історії України НАНУ, 1998. С. 324.

405 Стоцький Я. Українська Греко-Католицька Церква і релігійне становище Тернопільщини (1946-1989). Тернопіль, 2003. С. 34-35.

406 Гайковський М.I. Хресною дорогою: Функціонування і спроби ліквідації Української Греко-Католицької Церкви в умовах СРСР у 1939-1941 та 19441946 роках: збірник документів і матеріалів/ упоряд.: Гайковський М.І. Львів: Місіонер, 2006. С. 417-418.

407 Білас І., Репресивно-каральна система в Україні 1917-1953 Суспільнополітичний та політико-правовий аналіз. К.: Либідь, 1994. Кн. 1. С. 130.
} 
Soviet regime in the overall process of Sovietization of the Western Ukrainian lands in the post-war period. The only achievement of the initiators of the council, if it can be treated as such, was imitation of legitimacy and an attempt to present a violent action to the world as a "free will of the Ukrainian people".

However, these efforts were unsuccessful, as evidenced by the reactions and feedbacks in the press of the state bodies and numerous Ukrainian diaspora. It was obvious to the world society that a largescale action to liquidate the Ukrainian Greek Catholic Church at the Lviv Council in 1946 was carried out jointly with Communist regime and the Russian Orthodox Church in its interests. It was directed against the Vatican and Catholicism and aimed to weaken their position in the Christian world.

The Soviet side monitored the reaction of the Western world, carefully recording the responses of the world press, generating relevant information reviews based on them. One such review contained excerpts from various leading newspapers in Europe and the United States concerning the fate of the Ukrainian Church. In particular, the American "New York Times" on March 17, 1946 published materials on the decision of the Lviv Council and a negative statement by Cardinal Tisseran regarding the repression against the church and believers in Western Ukraine ${ }^{408}$.

UGCC hierarchs of the Ukrainian diaspora also condemned the Soviet regime and the leadership of the Russian Orthodox Church for the violent illegal and non-canonical affiliation of the Uniate Church with the Orthodox Church. On behalf of Ukrainians of Greek Catholic Canada, they stated, "As citizens of Canada, we demand that the freedom proclaimed by the Atlantic Charter extends to those unfortunate people who are being persecuted by the Soviets, we demand the liberation and right to return to their parishes and cease persecution of the Ukrainian Catholics"409.

\footnotetext{
408 ДАЛО. Фонд П-3. Оп.1. Спр.439. Арк. 46-47.

409 Гайковський М.І. Хресною дорогою: Функціонування і спроби ліквідації Української Греко-Католицької Церкви в умовах СРСР у 1939-1941 та 19441946 роках: збірник документів і матеріалів / упоряд.: Гайковський М.І. Львів: Мicioнep, 2006. С. 390.
} 
Representatives of the Ukrainian Autocephalous Orthodox Church continued their support for the persecuted UGCC, which continued to operate outside the Soviet occupation zone of the Ukrainian and Eastern European territories. In particular, the participants of the Second Council of Bishops of the UAOC under the chairmanship of Metropolitan Polycarp (Sikorsky), held from March 14 to 18, 1946 in the German town of Essling-on-Necker, approved the appeal to all Christian churches, as well as a separate appeal to the Catholic Church, which contained condolences about the forcible accession of the Greek Catholics to the ROC. Bishop I. Teodorovych, on behalf of the clergy and believers of the Ukrainian Autocephalous Church in North America protested, so as Exarch Ladyka and Bishop Savariy from the Ukrainian Catholic Church in Canada.

The Second Congress of Ukrainians of Canada in June 1946 adopted a special resolution stating that it was "protesting to the whole cultural and freedom-loving world against the violent intervention of the Soviet government in the cause of the faith of the Ukrainian people and the use of the Russian Orthodox Church to consolidate its dictatorship over the Ukrainian people" ${ }^{\text {"410 }}$.

The defeat of the UGCC was particularly painful and outrageous with the representatives of the Foreign Office of the Ukrainian Supreme Liberation Council (UHVR) and OUN foreign units, as well as a large number of Western Ukrainian emigrants. In connection with the tragic events at home, UHVR issued in May 1946 an appeal to all Ukrainians abroad ${ }^{411}$. In another statement, the leadership of UHVR informed the world society that in Ukraine "the religious sentiments of the Ukrainian population are being harassed by Bolsheviks... The whole action was aimed at: a) destroying the Greek Catholic Church as a religiously national institution that very seriously protects the Ukrainian people from the Russification influences of Moscow, b) to break with the help of terror some of the clergy, to force it to cooperate with the NKVD and thus to undermine the authority of the church among our people in general" ${ }^{\prime 412}$.

\footnotetext{
${ }^{410}$ Швець І. Збірник. Статті, доповіді, промови. Сідней, 1996. С. 189.

411 Релігія в житті українського народу: зб. матеріалів. Мюнхен; Рим; Париж, 1966. C. 288.

412 Ibid. C. 289.
} 
Speaking of positive feedback on the decisions of the Lviv Council, only the representatives of the Orthodox Churches - Exarch of Bulgaria Stefan, Archbishop of New York, Carpathian-Rus' and of Vilna Corneliy, sent their congratulations to the Moscow Patriarch Alexy.

As for the scientific assessments of the Lviv Council itself and the decisions taken on it, in the church circles that have maintained the faithfulness to the union, and in scientific researches, the Council and the adopted resolutions are considered as illegitimate and noncanonical. Most contemporary church and secular scholars of the UGCC history follow these approaches. The essence of their position is as follows. The council in its current form was not legally able to resolve the issue of reunification of the churches. The meeting, referred to as the Council of the Ukrainian Greek Catholic Church, took place without the participation of any of its bishops, who were in prisons and exile. These facts automatically make it uncanonical, and the decisions made in that case were illegal because they grossly violated church laws established by the Ecumenical Councils. Therefore, according to church canons, none of the decisions of the Lviv Council can be considered legitimate.

Secondly, G. Kostelnyk was appointed head of the UGCC with the rights of its metropolitan not by the Vatican, that is, by the ecclesiastical authority, but by the decision of the Soviet regime, which, according to the provisions of the constitution for the separation of the church from the state, had no legal rights. In addition, the delegates of the council were not elected under canon law, and therefore could not legally and canonically represent the whole community of the clergy and the faithful. According to the historian of the church, Y. Fedoriv, "any council that goes against the will of hierarchs, without the participation of bishops, is not a council. Its decisions have no canonical significance. This (in theory) is also recognized by the Russian Orthodox Church",413.

According to Y. Herych, in accordance with church laws, the Russian Orthodox Church as a local church did not have the right to interfere in the internal affairs of another local church, especially the

${ }^{413}$ Федорів Ю. Історія Церкви в Україні. Торонто, 1967. С. 315. 
Greek Catholic, subordinated to the Vatican. Thus, in his opinion, the Soviet authorities, which, according to a secretly concluded plan and with the help of the repressive bodies and the ROC, liquidated the Greek Catholic Church in the territory of Ukraine, and formally consolidated this action with the Lviv pseudo-council in 1946, violated elementary human rights recognized worldwide, even in other totalitarian states ${ }^{414}$.

This view is supported by I. Bilas, who, comparing the liquidation of the Metropolitanate of Kyiv in 1839 and Lviv in 1946, concluded that the leader of the liquidation of the UGCC, G. Kostelnyk, was not its metropolitan, like Metropolitan J. Semashko was, he had no authority to convene the council in 1946, and did not seek the approval from the highest ecclesiastical authority. Thus, the council of 1946 was convened against all the rules of the Catholic Church. The council in Lviv aims to liquidate the Greek Catholic Church and therefore cannot be called a Greek Catholic. Therefore, all Catholics were morally obliged to reject the decisions of this council, because according to the norms of the Catholic Church, such a council is illegal. G. Kostelnyk also did not receive authority from the ROC, because he was not Orthodox. The council of 1946 could not be Orthodox for the reasons that the decisions of the council did not concern the Orthodox, but the non-Orthodox. Thus, Kostelnyk could only be authorized to convene such a council from the government of the UkrSSR. Since the council of 1946 solved matters of great importance that could drag the country into international complications, it is clear that G. Kostelnyk could not convene the council at his own risk and on his own behalf. Therefore, the council is not a private issue, but a state event.

The Lviv council of 1946 was the culminating moment of the antiunion policy of the Soviet authorities and aimed at the elimination of Greek Catholicism in Western Ukraine. In the course of the research, it was found out that the decision to convene the council was not made by church figures, even by members of the Initiative Group, but by the state security service. In the opinion of the special services, the council, as an action of church-canonical registration of the process of

414 Герич Ю. Як відбувався «возсоєдинительний собор» у Львові 8 березня 1946 р. Календар «Світла». Торонто; Нью-Йорк, 1995. С. 88-91. 
transfer of Greek Catholics to the jurisdiction of the ROC, had to formally complete the process of liquidation of the union in Galicia.

The political regime, which established itself in 1944 in the Western Ukrainian region, was of a totalitarian nature and acted exclusively by command, administrative, and repressive methods. The Communist Party, the majority of which were newly arrived Russians from the east, promoted the unification of the sociopolitical, economic, and church-religious life of the region in accordance with models in the Soviet Union. In this connection, mass deportations of patriotic Ukrainians to Siberia, as well as actions to discredit the Greek Catholic clergy and the new bishop of the UGCC, Josyf Slipyj, began. In response, the OUN leadership appealed to the population in July 1945 not to undergo conversion to Russian Orthodoxy $^{415}$.

However, after the devastating blows of totalitarianism, the Greek Catholic Church did not perish in the Precarpathian lands. It was reorganized in the catacombs and served underground for almost half a century.

In general, the catacomb period of church activity can be divided into three stages: 1) resistance to the repressive actions of the authorities, 1946-1953; 2) organizational revival of structures and activation of underground activities, 1953-1963; 3) the struggle for the preservation of the church and its legalization, 1963-1989. The most important, in our opinion, were the last years of the Stalin regime. Even before the Lviv "council", in April 1945, the entire ecclesiastical hierarchy - Metropolitan Josyf Slipyj and ten bishops were arrested and, on the verdict of the Military Tribunals in Kyiv, imprisoned for a long time ${ }^{416}$. None of them renounced their faith and loyalty to the Apostolic See in exchange for the freedom promised by the NKVD. Bishops Hryhory Khomyshyn, Josafat Kotsylovsky, Mykyta Budka, Hryhory Lakota died in prisons and in exile. The bishop of Mukachevo Theodore Romzha was killed in the fall of

415 Сергійчук В. Нескорена церква: Подвижництво греко-католиків України у боротьбі за віру і державу. Київ, 2001. С. 72-75.

${ }^{416}$ Від прокурора УРСР. Вільна Україна. 1946. 1 березня. 
$1947^{417}$. During 1945 - 1946, the Soviet security authorities arrested over 800 Greek Catholic priests and threw them into prisons and concentration camps ${ }^{418}$.

The main reason for the arrest was the resistance to conversion to Orthodoxy. "Arguments" of the power were accusations of "cooperation" with the Nazis (J. Slipyj blessed the soldiers of the "Galicia" division to fight the Red Army), as well as with the Ukrainian rebels, among which the chaplains served ${ }^{419}$.

As a result of resistance of the Greek Catholic clergy and believers, the implementation of the decisions of the Lviv "Council" has been extended for several years. At the end of 1947, only 1,124 of the 2,700 priests accepted Orthodoxy ${ }^{420} .312$ parishes were converted to orthodoxy ${ }^{421}$. According to information from the Lviv region, at the end of 1946, 101 parsons refused to convert to Orthodox Christianity, and in addition, 55 people were arrested. Many priests went on to secular life. In the region, the number of existing churches sharply decreased - to 269 , ie twice only in 1946 . The same pattern was observed in the Transcarpathian region, where in 1947 Malyi Berezny and Boroniav monasteries were liquidated, and 173 parishioners from 299 refused to leave their native church, even after 128 of them were arrested and sent to Siberia or Kazakhstan ${ }^{422}$.

With the active involvement of law enforcement, most Greek Catholic parishes have been converted to Orthodox. In particular, in 1946 Orthodox became 1685 temples, in 1947 - 222, 1948 - 56,

417 Пушкаш Л. Кир Теодор Ромжа. Життя і смерть єпископа. Львів, 2001. С. 77-135; Судоплатов П. Разведка и Кремль. Москва, 1996. С. 299-300; Баран В. Україна: новітня історія(1945-1991 рр.). Львів, 2003. С. 72.

${ }^{418}$ Gudziak B., Hurkina S., Turij O. Hierarchia i duchowieństwo ukraińskiego kościola grecko-katolickiego w podziemiu.Polska - Ukraina. 1000 lat sąsiedztwa. T. 4. Przemyśl, 1998. S. 311-312, 315.

419 ДАІФО.Ф. Р-389. Оп. 1. Спр. 4. Арк. 79.

${ }^{420}$ Ibid. Ф. 4648. Оп. 4. Спр. 4. Арк. 40.

${ }^{421}$ Gudziak B., Hurkina S., Turij O. Hierarchia i duchowieństwo ukraińskiego kościola grecko-katolickiego w podziemiu.Polska - Ukraina. 1000 lat sąsiedztwa. T. 4. Przemyśl, 1998. S. 315.

422 ЦДАВО України. Ф. 4648. Оп. 3. Спр. 8. Арк. 34; Бендас Д. Священики мученики, сповідники вірності. Ужгород, 1999. С. 72-74. 
1949 - 327; in 230 "unincorporated" temples the church service was terminated $^{423}$.

On the eve of the first arrests, the leaders of the Metropolitanate took care of the preservation of the church hierarchy. In the spring of 1945, Metropolitan Josyf Slipyj appointed four administrators of the Metropolitanate at once - his successors: Bishops Mykyta Budka (1877-1949) and Mykola Charnetsky (1884-1959), Archimandrite Klymentiy Sheptytsky, and J.de Vokht from the Order of Redemption $^{424}$. After the NKVD authorities arrested both bishops together with Metropolitan in April 1945, the Metropolitanate was headed by Fr. Klymentiy Sheptytsky. Because of his arrest in June 1947, the management moved to Fr. J. de Vokht, a Belgian citizen who had to leave Galicia at the end of 1948. I.Ziatyk became the head of the Metropolinate but the KGB authorities arrested him and sent to Siberia, where in 1950 a priest died of beating. The duties of the underground church leader were assumed by Fr. M. Khmiliovsky, who, under the pseudonym Mykhaylo Lavrivskyi was hidden in the survived female monasteries, appealed to the clergy and the faithful with letters, lifted their spirits in the struggle to preserve the church in the catacombs. At the same time, he cooperated with the Ukrainian underground of the OUN and the UPA. However, M. Khmiliovsky in 1949 was captured and sentenced to exile ${ }^{425}$. Remaining without a higher hierarchy, the local structures of the church continued to operate.

Similar measures to appoint his successors were taken before his arrest in April 1945 by Stanislav Bishop Hryhory Khomyshyn ${ }^{426}$. He ordained as bishops-assistants the professors of the Theological Seminary S. Lukach, S. Vapovych and I. Slesyuk and appointed Fr. G. Balagurko as the General Vicar of the eparchy, who had to succeed

\footnotetext{
423 Баран В. Україна: новітня історія (1945-1991 рр.). Львів, 2003. С. 72.

424 Кардинал Йосип Сліпий і сучасність. Івано-Франківськ, 2002. С. 125-128; Боцюрків Б. Українська Греко-католицька церква в катакомбах (1946-1989). Календар «Благовіста». 1998. С. 93.

${ }^{425}$ Gudziak B., Hurkina S., Turij O. Hierarchia i duchowieństwo ukraińskiego kościola grecko-katolickiego w podziemiu.Polska - Ukraina. 1000 lat sasiedztwa. T. 4. Przemyśl, 1998. S. 312.

426 Rublowa N. Świadectwo wiary... Polska-Ukraina. 1000 lat sąsiedztwa. T. 5. Przemysl, 2000. S. 123-127.
} 
him. However, in 1945 G. Balagurko, S. Lukach and I. Slesyuk were arrested, charged with "cooperation with the Germans", "organization of an illegal bishopric", "illegal ties with the Vatican" and sentenced to long terms of imprisonment. Only Fr. S. Vapovych managed to avoid arrest and escape to the Carpathians, but he could no longer manage the eparchy. The same was the situation in Transcarpathia. On the eve of the tragic death, Bishop Theodore Romzha consecrated Bishop Olexandr Hira. But as early as 1949, the heir was arrested and exiled to Siberia (died in 1983) ${ }^{427}$.

On September 20, 1948 one of the "initiators" of the "cathedral" in 1946, Fr. G. Kostelnyk was killed at the exit of the Church of Transfiguration in Lviv. The circumstances of his death and the organizers of the action have not been revealed till nowadays. Lviv archives, including the Security Service of Ukraine, do not even have investigation documents. Authorities have accused the OUN in the organization of a terrorist act (the murderer V. Pankov allegedly committed suicide) and used this to launch a new wave of repression against the liberation movement and the unconquered church. The secretary of the "group" Serhiy Khrutsky was evicted to the Kemerovo region. Another "initiator" was soon poisoned in a train when he returned from Moscow. The other members of the group died not by their own natural deaths ${ }^{428}$. The offensive against the priesthood has increased even more since the assassination of Yaroslav Halan in 1949 in connection with involvement in the action by priests. During this dramatic period, the Metropolitan, 10 bishops, 1400 priests and 800 UGCC monks and nuns were repressed. Even Greek Catholic icons were painted over ${ }^{429}$.

Despite the physical threats posed by law enforcement agencies, only half (116 of 235) of the Trans-Carpathian Greek Catholic priests accepted the jurisdiction of the Moscow Patriarchate by 1949. Therefore, in March 1949, the authorities initiated an appeal "To the Greater Clergy and All Pious Believers of the Greek Catholic Church

\footnotetext{
427 Пекар А. Нариси історії Церкви Закарпаття. Т. 2. Рим; Київ, 1997. С. 491.

${ }^{428}$ Пащенко В. Греко-католики в Україні (від 40-х років ХХ століття до наших днів). Полтава, 2002. С. 106; ЦДАГО України. Ф. 1. Оп. 24. Спр. 3613. Арк. 1-2. ${ }^{429}$ Винниченко І. Україна 1920-1980-х рр.: депортації, заслання, вислання. Київ, 1994. С. 62; ДАТО. Ф. Р.3270. Оп. 2. Спр. 17. Арк. 30.
} 
in Transcarpathia", signed by the rectors of six churches and monasteries led by Archdeacon Irynei Kondratovych (1881-1957), a former member of the Communit Party of Hungary (1919). These priests performed similar functions as G. Kostelnyk's group in Lviv. On August 28, 1949, a group of 35 priests proclaimed the liquidation of the Uzhgorod Union in 1646 and reunited with the ROC. On the same day, thousands of believers who traditionally gathered for the Feast of the Assumption of the Virgin Mary at the Holy Nicholas Monastery on Chernecha Mountain in Mukachevo, learned of this "joyful" action ${ }^{430}$. And only about 80 parishes with 44 churches of the Mukachevo Eparchy, which appeared in Slovakia in 1944, were registered at the Apostolic Administration of the Mukachevo Eparchy (General Vicar A. Tynk), which Rome canonically subordinated to the jurisdiction of the Bishop of Presov ${ }^{431}$.

Despite the persecution, much of the Greek Catholic clergy continued to resist the communist regime. It took various forms and methods: active - outright refusals to accept Orthodoxy, agitation among the faithful, or passive - formal rejection of their parishes and the underground service of the church rituals ${ }^{432}$.

The OUN and UPA leadership led a decisive fight against the forcible conversion of the population of the region to Orthodoxy, openly threatened to converted parishes and sometimes committed terrorist acts against them. In particular, four priests were killed in the Stanislaviv region before $1952^{433}$. A large number of priests, including those who were forced to convert to Orthodoxy, worked closely with the Ukrainian underground. The monks of the Hoshiv Monastery cared for the wounded rebels and raised money for them $^{434}$. At the end of 1952 in the Stanislav region under the influence of the OUN fighters, 63 parishioners refused to leave the

\footnotetext{
430 ЦДАВО України. Ф. 4648. Оп. 3. Спр. 80. Арк. 31; Пащенко В. Грекокатолики в Україні (від 40-х років XX століття до наших днів). Полтава, 2002. С. 126-129; Сергійчук В. Нескорена церква: Подвижництво греко-католиків України в боротьбі за віру і державу. Київ, 2001. С. 155.

431 Пекар А. Нариси історії Церкви Закарпаття. Т. 2. Рим; Київ, 1997. С. 324.

432 ДАІФО. Ф. Р-389. Оп. 1. Спр. 6. Арк. 123; ДАТО. Ф. П-1. Оп. 1. Спр. 2345. Арк. 76.

Андрухів І. Галицька Голгофа. Івано-Франківськ, 1997. С. 38.

${ }^{434}$ ЦДАГО України. Ф. 1. Оп. 24. Спр. 13. Арк. 1-14.
} 
UGCC. There were 70 church communities operating here. At the same time, 22 priests returned to the Stanislaviv Orthodox Bishop a certificate of adherence to Orthodoxy ${ }^{435}$.

Large-scale force and propaganda campaigns succeeded in converting 1124 priests to Orthodoxy and handing over 2,500 churches in Western Ukraine to the ROC. At the initiative of the USSR government, Greek Catholic parishes were liquidated in Romania in 1948, and in April 1950 the hierarchs of the Eparchy of the Greek Catholic Church in Czechoslovakia were arrested and converted to Orthodoxy. Bishop Pavel Gojdic, sentenced to life in prison, died there; Assistant Bishop V. Hopko was only released during the "Prague Spring" in 1968, when the Greek Catholic Church became legalized ${ }^{436}$. In 1944-1956, the activities of the Greek Catholic communities were also suspended in Poland (the General Vicariate was created in 1967, the Przemysl Eparchy was established in 1991, and the Przemysl-Warsaw Metropolinate of UGCC was established in 1996) ${ }^{437}$.

The monks gave the great resistance to totalitarian authorities, only a few of them denied the union. Despite the brutal repression and harassment, by the end of the 1940's there were three in the Lviv region, and six Greek Catholic monasteries in the Stanislav region (Pidmykhailivtsi, Hoshiv, Voynyliv, Stanislav) ${ }^{438}$. Believers from the surrounding villages, where the Greek Catholic communities had already been liquidated, came to the monasteries and convents in Hoshiv in the Bolekhiv district. Consequently, the priests and monks continued their religious activities as parish priests and catechists.

\footnotetext{
435 Андрухів І. Галицька Голгофа. Івано-Франківськ, 1997. С. 38.

${ }^{436}$ Ісіченко І., архиєп. Історія Христової церкви в Україні. Харків, 1999. С. 200; Пекар А. Нариси історії, церква Закарпаття. Т. 2. С. 282-380; Магочі П. Пряшівська греко-католицька єпархія: русинська чи словацька церква? Ковчег. Ч. IV. Львів, 2003. С. 170-173.

${ }^{437}$ Ukraińcy w najnowszych dziejach Polski(1918-1989). T. 1 / Pod red. R. Drozda. Slupsk; Warszawa, 2000. S. 159-184; Drozd R. Polityka władz wobec ludności ukraińskiej w Polsce w latach 1944-1989. Warszawa, 2001 S. 30-307; Козак М. Пом'яни, Господи, душі слуг твоїх. Перемишль; Львів, 2002. С. 14-22.

438 ЦДАВО України. Ф. 4648. Оп. 3. Спр. 80. Арк. 34; ЦДАГО України. Ф. 1. Оп. 24. Спр. 12. Арк. 96-105.
} 
On September 29, 1949, in a report to Nikita Khrushchev, P. Vilkhovy, the Commissioner of the Council for Religious Cults under the USSR Council of Ministers on the UkrSSR, stated his deep concern of such a situation. And in the beginning of December of the same year he was received by the Deputy Chairman of the Council of Ministers of the UkrSSR Leonid Korniets, with whom he discussed "proposals for the liquidation of all monasteries". Therefore, the "commissioner" prepared proposals for the closure of three Greek Catholic monasteries in Lviv region, and on December 9, 1949 L. Korniets sent to the head of the Lviv regional executive committee Semen Stefanyk "instructions for taking measures". However, he didn't had strong intentions to go against public opinion ${ }^{439}$. The female monasteries survived for the longest period, especially in the village Sukhovoly (till 1952) and the city of Lviv (till 1957). The activity of all the others were ceased by the Soviet authorities in 1950 , when, as a result of mass repression, about one hundred nuns and forty female servants were arrested and deported to Siberia and the Far East, 29 of whom died in exile ${ }^{440}$. Those who left have created smallcongregations, mostly in private urban dwellings. They continued to work as nurses, seamstresses, cleaners, and at the same time served as liaison between clergy and laymen ${ }^{441}$.

By the early 1950s, the Soviet government officially abolished five Greek Catholic eparchies and two apostolic administrations, and imprisoned all the rulers. From the Greek Catholic bishops, Ivan Buchko, who in 1945 was named by the Pope as an exarch and apostolic visitor for Ukrainian Catholics in Western Europe, remained at freedom (he was in the Vatican). As evidenced by the certificate of the Commissioner for Religious Cults under the USSR Council of Ministers of the UkrSSR, P. Vilkhovy, from October 6, 1949 in the

\footnotetext{
439 Сергійчук В. Нескорена церква: Подвижництво греко-католиків України в боротьбі за віру і державу. Київ, 2001. С. 232; ЦДАГО України. Ф. 1, оп. 24, спр. 12, арк. 97-99.

${ }^{440}$ Боцюрків Б. Українська Греко-католицька церква в катакомбах (1946-1989). Календар «Благовіста». 1998. Гурово Іловецьке, 1998. С. 94; Сергійчук В. Нескорена церква: Подвижництво греко-католиків України в боротьбі за віру і державу. Київ, 2001. С. 253-260.

441 Сапеляк А. Київська церква на слов'янському сході. Буенос-Айрес; Львів, 1999. C. 188.
} 
western regions there were closed all existing Greek Catholic temples, including in Drohobych - 658, Stanislav - 567, Lviv - 522, Trenopil - 539, Chernivtsi - 2, Volyn - 2, as well as the bigger part of the monasteries ${ }^{42}$. However, only one-third of the priests converted to Orthodoxy, $15 \%$ were saved by escape or emigration, and half of those who were removed from the service, were repressed or converted to church underground ${ }^{443}$.

Under these conditions, parishioners for the most part kept loyalty to the faith of their fathers, so often they confessed only to their former pastors and boycotted the Orthodox priests. As a result, for example, eight priests were changed in Zhovkva, Lviv region in $1946-1949^{444}$. In the Stanislav region in 1949 , there were only 276 priests in 605 churches. The situation has not improved over the next four years: in 1953, there were only 240 priests in the 614 operating churches ${ }^{445}$.

The church service of the Greek Catholic rite by the Orthodox priests, at the request of parishioners, was a common phenomenon. This was a form of resistance to the Soviet regime and $\mathrm{ROC}^{446}$.

Metropolitan Josyf Slipyj, in the difficult conditions of exile, sent pastoral letters to the clergy and faithful, which were spread throughout the believers. For example, on the occasion of Christmas 1947, he called on all Greek Catholics to steadfastly withstand the persecution of the authorities, to remain faithful to their father's faith and to the church that had always served their people faithfully ${ }^{447}$. Together with Metropolitan, dozens of oppositional priests, who continued pastoral activity in prisons, concentration camps, and settlements, were exiled.

\footnotetext{
442 Сергійчук В. Нескорена церква: Подвижництво греко-католиків України в боротьбі за віру і державу. Київ, 2001. С. 220.

443 Ісіченко І., архиєп. Історія Христової церкви в Україні. Харків, 1999. С. 200-201; Архів УСБУ по Львівській обл. Спр. о. Матея (Шипітки). П-34395. Арк. 57, 69, 107, 269.

${ }^{444}$ ЦДАВО України. Ф. 4648. Оп. 3. Спр. 70. Арк. 28.

445 Андрухів І. Галицька Голгофа. Івано-Франківськ, 1997. С. 38-50.

446 Боцюрків Б. Українська Греко-католицька церква в катакомбах (1946-1989). Календар «Благовіста». 1998. Гурово Іловецьке, 1998. С. 95.

447 Мартирологія українських церков. Т. II: Українська Греко-католицька церква. Торонто; Балтимор, 1987. С. 470.
} 
The death of J. Stalin in March 1953 gave rise to wide hopes of legalization of the church. In the same year, there were recorded the first complaints of believers and the clergy about the return of the religious buildings, which were given to the collective farms and various organizations. Moscow, in the person of the "reformer" L. Beria, even began negotiations with Metropolitan Josyf Slipyj ${ }^{448}$, as evidenced by his letter to the then secretary of the Central Committee of the Communist Party of Ukraine, M. Pidhorny, sent to Kyiv in January $1961^{449}$. Being inprisoned, Metropolitan wrote a "History of the Ecumenical Church in Ukraine", which was confiscated by the Interior Ministry, and its author was sentenced in 1959 to eight more years of exile.

On March 27, 1953, there appeared a decree of the Presidium of the Supreme Soviet of the USSR on the amnesty of the prisoners, who had to stay in jail up to five years. In addition, in September a decree gave the Supreme Court the right to review the infamous decisions of the NKVD "triples" and the special meeting of the NKVD-KGB-MIA of the USSR, which affected most of the repressed Greek Catholics. Thus, during the Khrushchev "thaw", tens of thousands of exiles returned to their native land, including liberated Greek-Catholic priests ${ }^{450}$. By March 1957, 65.5 thousand Ukrainians had arrived, many of them were priests. On August 6, 1956 a letter to the chairman of the ROC Committee of the USSR Council of Ministers from Kyiv reported that of the repressed 344 Uniate priests there returned to the western Ukraine 243 of them. Most of them have already started religious activities, did a service, campaigned against the ROC and its patriarch Alexy. Numerous statements were received by the authorities from the believers with the requirements of the UGCC rehabilitation, registration of church communities in accordance with the Constitution ${ }^{451}$.

\footnotetext{
448 Пащенко В. Греко-католики в Україні (від 40-х років ХХ століття до наших днів). Полтава, 2002. С. 151.

449 Сліпий Й., митр. Історія Вселенської церкви на Україні. Т. 4, ч. 1. Рим, 1996. С. 1-3; Архів Служби безпеки України. Спр. 87. Т. 10. Арк. 278; Т. 5. Арк. 295.

450 Сергійчук В. Нескорена церква: Подвижництво греко-католиків України в боротьбі за віру і державу. Київ, 2001. С. 285-288; Пащенко В. Греко-католики в Україні (від 40-х років ХХ століття до наших днів). Полтава, 2002. С. 146-147; Арсенич П. Йосиф Сліпий та його соратники - репресовані священики. Кардинал Йосиф Сліпий і сучасність. С. 126-127.

${ }^{451}$ ЦДАГО України. Ф. 1. Оп. 24. Спр. 4263. Арк. 202-205.
} 
We should agree with the researchers that 1953 can be considered the last year of the internal crisis, in which the repressed church was after the so-called Lviv "council"" 52 .

The repressed Uniate priests were financially and morally supported by the Roman Catholic clergy of Transcarpathia, Drohobych and Lviv regions. For the Oriental Catholics, church services were often celebrated during the Orthodox holidays in accordance with the Greek Catholic rite ${ }^{453}$.

Of great importance for the catacomb church was the return of hierarchs, in particular Bishop M. Charnetsky to Lviv in 1956, Bishop I. Lyatyshevsky to Stanislav, and Bishop O. Hira to Mukachevo. Despite constant surveillance and the threat of repression, they primarily restored church structures, strengthened the church organizationally, and cared for the replenishment of clergy to work underground. In April 1959, Bishop M. Charnetsky ordained fifty priests during the two years before his death. He accepted another 280-300 priests to the UGCC from the Orthodox Church. They wished to return to their native church, officially remaining in the service $^{454}$. Bishop I. Lyatyshevsky (1870-1957), although the relevant Soviet authorities monitored and recorded all his visitors, united priests in Stanislaviv region, formed an initiative group for the revival of the UGCC, which made numerous statements to the authorities. The number of unbundled parsons in the area has increased to $84^{455}$. They conducted extensive pastoral work, although the authorities persecuted them, searched, seized church books, and imposed penalties. Often, non-Orthodoxy communities opened their own churches in which underground clergy send the Divine Service (usually on major religious holidays). In 1958, 14 Greek Catholic churches operated in the Stanislaviv region ${ }^{456}$. Widespread listening

\footnotetext{
452 Пащенко В. Греко-католики в Україні (від 40-х років ХХ століття до наших днів). Полтава, 2002. С. 143.

453 Сергійчук В. Нескорена церква: Подвижництво греко-католиків України в боротьбі за віру і державу. Київ, 2001. С. 236; Пащенко В. Греко-католики в Україні (від 40-х років ХХ століття до наших днів). Полтава, 2002. С. 168-169.

454 Бойко I. Владика Миколай Чарнецький: ісповідник, мученик, чудотворець. Львів, 1997. С. 61.

455 ДАІФО. Ф. Р-389. Оп. 2. Спр. 18. Арк. 102-103.

456 Андрухів І. Галицька Голгофа. Івано-Франківськ, 1997. С. 55-56.
} 
to religious radio broadcasts from the Vatican, which was organized specifically for Greek Catholics in Ukraine, has become common.

It is clear that the process of returning from exile of the opposition clergy was extremely disturbing to the authorities of the western regions of Ukraine. On April 6, 1955, in a letter to Moscow, the secretary of the Lviv Regional Party M. Lazurenko reported that there returned to Ukraine 30 former priests of the UGCC and the former General Vicar of the Metropolitan, M. Khmilevsky, who was secretly ordained as a bishop, and who had been sentenced for 10 years in prison in 1950 for cooperation with the OUN and UPA and a relationship with the Vatican. M. Lazurenko complained that almost all of them conduct "activities hostile to the Soviet authorities", keep contacts with Metropolitan J. Slipyj and other UGCC hierarchs in exile, provide them with material assistance ${ }^{457}$.

After returning from their places of imprisonment, Greek Catholic priests became actively involved in the activities of the catacomb church. In a report to Moscow on December 10, 1956, the commissioner of the ROC Affairs Council under the Council of Ministers of the UkrSSR, Korchovy, reported that of the 267 priests, who returned, only 14 agreed to lead Orthodox parishes, while the rest held underground worship in the Greek Catholic rite, became the "moral base of the OUN underground" "58. Therefore, the Soviet authorities took all measures to combat the UGCC, involving the Russian Orthodox Church. A special meeting of the ROC Affairs Council under the Council of Ministers of USSR, on April 10, 1959, adopted a secret resolution to strengthen the work to "eliminate the remnants of the union in the western regions of the USSR", which envisaged the activation of the Moscow Patriarchate of the Orthodox priesthood against the underground UGCC. The priests were asked to expose the Vatican as the enemy of Orthodoxy and the instigator of the Cold War, to combat the clandestine activities of the Uniates, to bring their cases to court, to evict outside the regions, to register only Orthodox Church communities, to suspend the payment of pensions to the families of the inprisoned priests ${ }^{459}$. However, this counterpropaganda was ineffective.

\footnotetext{
${ }^{457}$ ЦДАГО України. Ф. 1. Оп. 24. Спр.4081. Арк. 2-5.

458 ЦДАГО України. Ф. 1. Оп. 24. Спр. 4263. Арк. 288-300.

459 Ibid. Оп. 24. Спр. 5028. Арк. 65-67.
} 
The international community also opposed the lawlessness in the USSR. In December 1962, at a meeting with M. Khrushchev, US Ambassador N. Kazens sent a request to J. Kennedy and Pope John XXIII to release Metropolitan J. Slipyj. Therefore, at the beginning of February 1963, Metropolitan left for Rome, where he participated in the Second Vatican Council as the head of the UGCC. On his way, during his short stay in Moscow, he consecrated as a Redemptorist Bishop the Abbot Vasyl Velychkivsky and appointed him as a head of the UGCC in the underground ${ }^{460}$.

Metropolitan J. Slipyj was active in Rome. Already in 1963, the Ukrainian Catholic University of St. Clement the Pope was established. On the following year, the monastery for the monksstudents was opened, as well as the cathedral of Saint Sophia - the spiritual center of the Ukrainian Greek Catholics, and the publication of the magazine "Theology" was established. Metropolitan kept in touch with the region (mainly through Poland), sent pastoral letters, and provided information on the activities of the religious underground. Pope Paul VI named J. Slipyj the Supreme Archbishop of the Ukrainian Catholic Church and Cardinal. Appointment of V. Velychkovsky as Archbishop by J. Slipyj proved to be an extremely successful choice. It led to the extensive construction of the UGCC in the catacombs. At his initiative, the process of returning Orthodox priests was initiated. V. Velychkovsky founded three secret women's monasteries in Lviv: Monastery of the Servants, of St. Basil and St. Victoria, where girls made monastic vows. At a secret residence in Lviv, he met with the General Vicar of Przemysl, V. Hrynyk, through whom he maintained regular contact with Cardinal J. Slipyj. In case of a new arrest (and he had already served 10 years of exile), V. Velychkovsky in 1964 consecrated Volodymyr Sternyuk as a Bishop and Chorniy, N. Deyneka, P. Kozak and J. Girnyak as Assistant Bishops. In 1967 he reported to Cardinal J. Slipyj that 150 parishioners, over 100 Basilians, 60 students, 54 redemptorists were active in Galicia and

460 Чернега М. Життя і терпіння Спископа Величківського. Нова зоря. 1997. 27 травня; Сергійчук В. Нескорена церква: Подвижництво греко-католиків України в боротьбі за віру і державу. Київ, 2001. С. 402, 403, 404, 412, 416, 422. 
Transcarpathia. There were 240 Basil nuns in 14 secret houses. About 50 priests converted from Orthodoxy, 40 more were ordained ${ }^{461}$.

One of the biggest problems of the catacomb church in the 1960s was the replenishment of the Greek Catholic priesthood. By this time the reserve of the former seminarians, the monks who had escaped arrest, had run out. It was from this environment that Bishop M. Charnetsky consecrated fifty priests after a short period of study. There was a need to train priests from the young generation, who grew up in the conditions of a totalitarian system, which was dominated by the atheistic ideology. The undergraduate seminary courses mostly involved the sons and relatives of the Greek Catholic priests and lay activists. In addition, the training of candidates in the Orthodox seminary, as well as the Roman Catholic ones in Riga and Kaunas, was practiced. Underground training lasted 4-6 years or more in private homes with several and sometimes with one candidate ${ }^{462}$. Having successfully passed the exams before the priests, the students were allowed to be consecrated by the bishops V. Velychkovsky, V. Sternyuk and others. The consecration of Lviv candidates by the bishops of Stanislav and vice versa was practiced for conspecific purposes.

It should be noted that in the conditions of the underground activity the church structure, in particular the system of subordination, had its own peculiarities. The so-called "old" priests, ordained before 1946, recognized the rule of bishops of their diocese, that is, still under legal conditions. Priests, consecrated in the underground, obeyed the bishops who consecrated them. The priests acted independently, with almost no one working in their native places. From time to time, secret meetings have been organized, in particular in the city of Lviv - at home of Olena Kulchytska or in Transcarpathia. Those priests who formally adopted Orthodoxy also participated. The activities of the UGCC brought the hierarchy closer to the priesthood; the bishops worked directly among the people, and this fact positively influenced the Ukrainian society, facilitated its consolidation.

\footnotetext{
461 Gudziak B., Hurkina S., Turij O. Hierarchia i duchowieństwo ukraińskiego kościola grecko-katolickiego w podziemiu.Polska - Ukraina. 1000 lat sasiedztwa. T. 4. Przemyśl, 1998. S. 323.

462 Стоцький Я. Монастир Отців Василіян Чесного Хрес та Господнього в Бучачі 1712-1996. Львів, 1997. С. 135.
} 
Although the confrontation between the Greek Catholic Church and the Soviet authorities never ceased, the Khrushchev "thaw" days and the first years after its displacement in 1964 brought some relief from anti-religious pressure. This made it possible to restore the structure of the previous metropolis. Bishop V. Velychkovsky headed the Archdiocese of Lviv until his arrest in 1969. He had assistant priests A. Zofiyovsky and I. Chornyak, and in 1964 consecrated as the successor the Redemptorist Fr. Volodymyr Sterniuk. The IvanoFrankivsk Eparchy was ruled by Bishop Ivan Slesyuk (1893-1973), who consecrated as an assistant and successor Fr. S. Dmyterko. The Mukachevo-Uzhhorod Eparchy was governed by Bishop O. Hira. According to Fr. B. Botsyurkiv, in 1968 several hundred GreekCatholic priests, about 480 nuns, who were united in 14 secret religious houses, were active in Ukraine. The core of the church was the monastic orders - about 240 Basilians, students, and Redemptorists. 40 priests were ordained, 50 returned from Orthodoxy, 20 candidates were trained. In some localities, Greek Catholics opened closed temples and invited clergymen to attend. In fact, 88 Greek Catholic churches operated in western Ukraine ${ }^{463}$.

In these circumstances, governmental institutions have made a number of important decisions to combat both the "illegal activities of the Uniate Church and sectarians" and religion in general. In 1969, Bishop V. Velychkovsky, as well as prominent priests P. Horodotsky in Lviv and R. Bakhtalovsky in Kolomyia were arrested, searches were made in the premises of Bishop V. Sterniuk, in the premises of dozens of priests and monks. Many churches were removed from registration. The offensive on religion and the UGCC continued over the coming years, however, in less brutal forms. The KGB has widely used provocations to discredit the Greek Catholic hierarchy, including Bishop Volodymyr Sterniuk. In 70 closed temples of the western region, the authorities have equipped anti-religious, especially antiUniate museums and galleries, which, along with other factors, carried out ideological treatment of the population ${ }^{464}$.

M. Pidhorny's meeting with Pope Paul VI in 1967 and the events in neighboring Czechoslovakia in 1968 and the revival of the Greek

\footnotetext{
463 Боцюрків Б. Українська Греко-католицька церква в катакомбах (1946-1989). Календар «Благовіста». 1998. Гурово Іловецьке, 1998. С. 102.

464 Пащенко В. Православ'я в новітній історії України. Ч. 2. Полтава, 2001. C. 306 .
} 
Catholic Church there have intensified the activities of the clergy and faithful of the UGCC in western Ukraine. The message issued by the commissioner of the Council of Religious Affairs also did not help. It stated unequivocally that the Greek Catholic communities would not be registered as the UGCC was liquidated and the priests and initiators of the unlawful opening of Uniate churches would be punished by 10 years in prison. Applications for legalization of the UGCC continued to be received. The authorities were gravely concerned about the Ukrainian dissidents advocating for the UGCC. In the early 1970's Moscow launched a broad campaign to combat "Ukrainian nationalism". Seeing in the awakening of national consciousness a direct threat to the totalitarian communist regime, the Soviet authorities resorted to arrests and other repressive actions in order to intimidate the people and stop the national movement. The peak of the repressions occurred in 1972-1973. In December 1973, there were arrested bishops S. Dmyterko and I. Slesyuk, several priests. Soon, underground priests I. Kryvyi and P. Chuchman were murdered.

Helsinki agreements forced the Kremlin to weaken the offensive; on the other hand, they started legal movement for human rights. The coming to the Apostolic See of Pope John Paul II in 1978 intensified the Vatican's policies for the protection of the UGCC. In a letter to the Soviet government, the Holy Father, referring to the Universal Declaration of Human Rights, signed by L. Brezhnev in 1975, urged not to make obstacles to the believers. Moscow was particularly disappointed with the resolution of the Synod of Ukrainian Bishops in Rome of December 2, 1980, on the non-canonical charscter of decisions of the Lviv Council in $1946^{465}$.

Despite persecution and arrests, on September 9, 1982, an "Initiative Group for the Protection of the Rights of Believers and the Church" was formed. It was run by the later arrested and imprisoned dissidents J. Terelia and V. Kobryn, who set up the publishing house "Chronicles of the Catholic Church in Ukraine". The movement for the legalization of the church, to which the Ukrainian Helsinki Group and other opposition structures joined, had intensified ${ }^{466}$.

\footnotetext{
465 Боцюрків Б. Українська Греко-католицька церква в катакомбах (1946-1989). Календар «Благовіста». 1998. Гурово Іловецьке, 1998. С. 114.

466 Пащенко В. Православ'я в новітній історії України. Ч. 2. Полтава, 2001. С. 318; Історія України. Вид. 2-е. Львів, 1998. С. 381-401.
} 
During the 1980s, the UGCC lost its prominent hierarchs. On September 7, 1984, the Archbishop of Lviv, Cardinal Josyf Slipyj died in Rome. His successor was Myroslav Ivan Lyubachivsky, Cardinal since 1985. Bishop Olexandr Hira died in exile in Kazakhstan.

With the democratization of the USSR, almost all political prisoners, including Greek Catholic priests, were released in the late 1980s. They led the national movement for human rights and freedoms. Established in 1987 in Lviv, the Committee of Defence of the Ukrainian Catholic Church, under the leadership of Ivan Gel, published the magazine "Christian Voice", organized large gatherings of believers, and signed petitions for the legalization of the UGCC. In the same year, a group of Ukrainian Catholic clergy led by Bishop Pavlo Vasylyk announced their departure from the underground. Bishop V. Sternyuk, S. Dmyterko, and I. Marhitych were openly demanding the revival of the UGCC. This movement was especially intensified in connection with the state-level celebration of the 1000th anniversary of the baptism of Rus'-Ukraine. The UGCC actually went out of the underground, becoming a significant factor in Ukrainian statemaking ${ }^{467}$.

Thus, in the 1950s and 1980s, most Greek Catholics maintained the faith of their parents. Hundreds of priests continued their pastoral illegal activities, which intensified in the late 1950s - early 1960s after the return of a large proportion of prisoners from the Siberian camps and settlements. The repressed church was an expression of universal values, unlike the official one, which was an element of the ideological policy of the totalitarian system. Gorbachev's proclamation of a course on the restructuring and democratization of society created the conditions for church and religious revival in the UkrSSR, which was fully used by the political opposition and millions of believers. The religious opposition prepared the ground for the final stage of the struggle for the democratization of society, the return of its people to the world civilization.

467 Дідула П. Щоб не зрадити ідеї патріархату. Патріархат. 2002. № 3. С. 12-13. 


\section{PART 6. \\ THE UGCC AS A CHURCH-RELIGIOUS INSTITUTION OF INDEPENDENT UKRAINE}

Adequate representation of the public place and state-building role of Greek Catholicism in independent Ukraine at the beginning of the third millennium is impossible without a thorough analysis of the profound transformational processes in the religious sphere of the state and particularly the western region in recent decades. It is known that until 1988 the official government of the UkrSSR-USSR implemented a policy of forced secularization of the population. In the 1988-1991 a religious favouritism of Russian Orthodox Church was a sign of religious policy of the government. However, in the western regions this process ended in 1989, followed by the shortlived favoritism of the Ukrainian Autocephalous Orthodox Church. The political defeat of the pro-communist forces in the 1990 local elections in the Lviv, Ivano-Frankivsk and Ternopil regions marked the beginning of a period of religious pluralization. On a nationwide scale, the religious pluralisation of society was proclaimed in 1991, the time when independence was proclaimed. However, the sharp turn of the state authorities from the traditional church-religious policy was caused not so much by the democratism of its statements as by the real threat of significant social unrest on the ethno-religious field.

An important component of the national liberation movement of the late 1980s - early 1990s became a wide public movement for the restoration of the Ukrainian Greek Catholic Church, which "in its scope went beyond purely religious issues and acquired a political character" $^{\prime \prime 68}$.

The UGCC has shown exceptional vitality, and its clergy and believers - an unwavering faith in the restoration of the parental Church. The foundation of the Church's revival was the existence of

468 Кобута С. Політичні аспекти легалізації Української Греко-Католицької Церкви (1987-1991). Людина і політика. 1999. № 3. С. 23. 
active underground organization. According to the head of the UGCC in Rome, Cardinal Myroslav Lubachivsky, in the late 1980's, its underground consisted of ten bishops, about one thousand priests, one thousand two hundred monks and nuns, and 4.5 million believers ${ }^{469}$.Other data include reports from official authorities: in 1988 in the Lviv, Ternopil, Ivano-Frankivsk and Transcarpathian regions there were 260 priests, 385 monks and nuns and only 100,000 Greek Catholics believers ${ }^{470}$.

Movement for the legalization of the UGCC has been especially strengthened since the start of Mikhail Gorbachev's reforms, who in 1985 , in the face of a clear socio-economic crisis of the Soviet totalitarian system began a radical change in politics for its preservation. A course on the democratization of society, publicity and pluralism was proclaimed.

The turning point was the meeting of $\mathrm{M}$. Gorbachev with the hierarchs of the ROC on April 29, 1988 at which the General Secretary declared abolition of discriminatory acts on religion, return of the usurped churches to the communities, preparation of the new state law on freedom of conscience. He stressed that restructuring, publicity and democracy, without any restriction, refer to state-church relations ${ }^{471}$. This decision, among other reasons, was prompted by the state-level celebration of the 1000th anniversary of the baptism of Rus'-Ukraine. By the way, on this occasion Pope John Paul II in July 1988 in the St. Peter's Cathedral celebrated a Liturgy in Ukrainian language for 15,000 Greek Catholics of the West ${ }^{472}$

In order to avoid an aggravation of the religious situation the leaders of the UGCC in Rome have made attempts to contact and communicate with the leaders of the ROC in the USSR. In particular, on November 6, 1987 Cardinal M. Lubachivsky made an appeal to the Orthodox hierarchs with a proposal for reconciliation. The Synod

\footnotetext{
469 Кобута С. Політичні аспекти легалізації Української Греко-Католицької Церкви (1987-1991). Людина і політика. 1999. № 3. С. 24.

${ }^{470}$ ЦДАГО України. Ф. 1. Оп. 25. Спр. 3143. Арк. 41; Спр. 3330. Арк. 9-20; арк. 27.

471 Правда. 1988. 30 апреля.

472 Слово Святішого Отця Івана Павла II до України. Львів, 2001. С. 86-92.
} 
of Bishops of the UGCC, held in the Vatican from September 24 to October 8, 1988, made a similar appeal ${ }^{473}$.

However, in August 1987 a group of Lviv priests left the underground and signed a collective statement to Moscow for the legalization of the UGCC. This movement, which was widely supported by Greek Catholics, was led by Bishop from IvanoFrankivsk Pavlo Vasylyk ${ }^{474}$. Also in 1987, referring to the declared in Constitution of the USSR freedom of conscience, two bishops and 23 priests issued a petition-appeal to Pope John Paul II about leaving the underground and requests to support "in every possible way the case of legalization of Ukrainian Catholic Church in the USSR" "475. In October 1988, a delegation of the Ivano-Frankivsk eparchy of the underground UGCC arrived in Moscow and negotiated with the Council for Religious Affairs at the Council of Ministers of the USSR on the legalization of the Church. However, they ended without success, as the authorities at the time considered such statements and facts of the exit of parishes from the underground as a kind of manifestations of religious extremism. Moreover, on the orders of Moscow, the party organs of Ukraine tried to neutralize the activity of believers of the underground Church.The media intensified propaganda campaign to discredit the UGCC and anti-union content was urgently printed ${ }^{476}$.

The socio-religious movement in Western Ukraine was flowing into the powerful stream of the Ukrainian national revival of the late 1980s. The desire of the Soviet authorities for a democratic image in the world community narrowed its capabilities to combat it. In 1987, Moscow was forced to release about 300 Ukrainian political prisoners out of the 350 who, through formal publicity, were strongly involved in further fighting the totalitarian system. Leaders of the Ukrainian Helsinki Group, the Initiative Committee for the Release of Prisoners

\footnotetext{
473 Поступ. 2000. 13 травня.

474 Бюлетень релігійної інформації. 1997. № 13-14; Ієрархи Української Греко-Католицької Церкви в Україні. Поступ. 1999. 11 вересня.

${ }^{475}$ ЦДАГО України. Ф. 1. Оп. 25. Спр. 330. Арк. 9-20.

476 Ржезац Т., Цуркан В. Розшукуються... Київ, 1989. С. 20-113; Пащенко В. Греко-католики в Україні (від 40-х років XX століття до наших днів). Полтава, 2002. C. 446.
} 
of Conscience L. Lukyanenko, V. Chornovil, I. Gel, M. Horyn, S. Khmara actively supported the legalization of the UGCC. At the end of 1987 a recent political prisoner, Ivan Gel, founded the Committee for the Protection of the UGCC, which included church leaders. In order to promote social and political movement for the revival of the Church he established edition of the magazine "Christian voice" $"$.

The catalysts for the legalization of the underground Church were also the obstacles created by the authorities in celebration of the millennial anniversary of Baptism in 1988. Actually, at that time, Greek Catholics were able to conduct unauthorized by the authorities mass worships in the village Hrushiv of Lviv region and the village Zarvanytsya of Ternopil region. This once again drew the attention of the anti-communist opposition and the public to the problem of respect for the rights of believers and freedom of religion in the USSR. Thus, a wave of new church services of political character swept through many settlements in Lviv, Ivano-Frankivsk and Ternopil regions.

Groups of Greek Catholic bishops and priests have repeatedly appealed to higher authorities and international organizations for the legalization of the Church. In January 1989, Ivano-Frankivsk Bishop P. Vasylyk one more time requested M. Gorbachev to meet and negotiate on "urgent issues related to the organization of the Church"478. In May of the same year, a delegation of bishops and priests of the UGCC arrived to Moscow with a petition for M. Gorbachev to restore the Church, and they also negotiated in the Council on Religious Affairs. When the delegation did not receive a positive response, a group of Greek Catholics began a hunger strike in Moscow, which lasted until the end of November, 1989. In addition, petitions were sent to states-participants of the Vienna and Paris forums of the Conference on Security and Cooperation in Europe. Special attention was paid to the events in honor of the 1000th anniversary of the baptism of Rus'-Ukraine. When President Gorbachev met with Pope John Paul II in Rome and established

\footnotetext{
${ }^{477}$ ЦДАГО України. Ф. 1. Оп. 25. Спр. 3143. Арк. 49.

478 Документи патріаршого Собору Української Греко-Католицької Церкви. Перша сесія. Жовтень 1996 рік. Львів: Свічадо, 1998. С. 26.
} 
diplomatic relations between the USSR and the Vatican, it became possible to raise the issue of legalization of the UGCC and the registration of its communities at the highest level. As a result of these measures the Kremlin agreed to prepare a new law on freedom of conscience, which would be consistent with international legal acts on issues of human rights and religious freedom ${ }^{479}$.

Revival of the UGCC was actively promoted by Ukrainian sociopolitical groups: People's Movement of Ukraine, Helsinki Union, Ukrainian Christian Democratic Front, etc. The first gathering of the Movement in September 1989, which brought together about 280,000 members, adopted a resolution "On Churches in Ukraine". It declared freedom of religion, filled with real meaning the law on separation of the Church from the state, accused the ROC of serving the Communist regime, demanded legalization of the UGCC and condemned the Moscow Patriarchate for obstacles to the revival of national churches ${ }^{480}$. Nevertheless, the second gathering of the Movement in 1990, when the problem of legalization was solved and the process of revival and reconstruction of the Ukrainian Greek Catholic and Autocephalous Orthodox Churches began, noted the important role of religious factors in state building ${ }^{481}$.

Recognizing dangerous for the system situation in Ukraine, particularly in the western regions, party and security forces prevented the Greek Catholic movement from growing. They had high expectations of the Orthodox Church, whose hierarchy was openly opposed to the legalization of the $\mathrm{UGCC}^{482}$. Therefore, the Communist Party, the authorities and the ROC were united against the revival of the UGCC. Undoubtedly, the leaders of the ROC did not want to lose their influence in the western region, because in 1986 there were 1852 out of 6747 (27\%) ROC religious communities concentrated - one half of 4,418 (in 1988) Orthodox parishes in Ukraine. Their return to the UGCC could have seriously damaged the prestige and financial positions of Russian Orthodoxy. Thus, the state-level anti-unitary campaign, strengthened by the hierarchs of the

\footnotetext{
${ }^{479}$ Історія релігії в Україні. Київ: Знання, 1999. С. 614.

480 Літературна Україна. 1989. 19 жовтня; Вістник Руху. 1990. № 5. С. 20.

481 Літературна Україна. 1990. 1 листопада.

482 Правда Украины. 1989. 23 мая.
} 
ROC, continued until the end of 1989. During this period, the agonizing state transferred about 800 inactive temples to the ROC in Galicia, in order to avoid claims by Greek Catholics in the future. However, there was no unity among the Orthodox hierarchy ${ }^{483}$

In the second half of 1989 mass protests by Greek Catholics coordinated by hierarchs led by Archbishop Volodymyr Sterniuk gathered crowded religious actions. Its apogee - the demonstration of 100,000 people on September 17, in Lviv, under the slogans of legalization of the UGCC. The process of self-revitalization of the Greek Catholic faith developed into the possessing of parent churches. The first in the region to become the property of the UGCC on October 29 was the Transfiguration Cathedral in Lviv and the Church of the Holy Trinity in Shchyrka in Lviv region. Realizing that the process of reviving the Church could not be stopped, party-state officials tried to put it under their control. On November 21, 1989 the Council in Religious Affairs of the Council of Ministers of the UkrSSR issued a statement authorizing the registration of Greek Catholic communities, which were granted all the rights established by law for religious associations ${ }^{484}$.

Archbishop V. Sterniuk gathered the ecclesiastical council of the UGCC in Lviv on January 23, 1990 with the participation of six bishops and 150 priests. It proclaimed the legalization of the Church, recognized the pseudo-council of 1946 in Lviv as non-canonical, made demands to rehabilitate repressed representatives of the Greek Catholic clergy, to return to the Church its temples and to recognize the church organization of the UGCC. This act led to the process of mass transfer of the believers from Orthodoxy and registration of the Greek-Catholic communities. In February 1990, more than 435 applications for registration of the restored parishes were done. In addition, by the end of the year, 1677 Greek Catholic communities had been revived ${ }^{485}$. In early 1989, Bishop Sofron Dmyterko (who

\footnotetext{
${ }^{483}$ Московский церковный вестник. 1989. № 17. С. 3.

484 Ibid. Арк. 41.

485 Васьковський В. «Горячі точки»: стан справ і шляхи врегулювання. Людина i cвim. 1990. № 10. C. 31 .
} 
ordained more than 65 priests during the underground period) legalized pastoral activity in Ivano-Frankivsk ${ }^{486}$.

The decisive role in the process of community legalization was played by the initiative of democratically elected local councils, which, despite the uncertain policy of Kyiv, adopted radical statements and easily implemented them. In particular, on May 4, 1990, the Lviv Regional Council adopted a resolution "About religious denominations in Lviv region", which defined the procedure for the transfer of temples to the restored denominations, the St. George's Cathedral - the historical residence of the Metropolitan of the UGCC - returned to the Metropolitanate. Lviv Regional Council proposed to the Verkhovna Rada of UkrSSR to consider restoring the rights of the Ukrainian national churches ${ }^{487}$.

At the time of the UGCC's exit from the underground and during the first recovery period, it had only three eparchies in Ukraine: Lviv, Ivano-Frankivsk, and Mukachevo, which through the Apostolic Nuncio in Ukraine was subordinated to the Vatican. They formed the Metropolitanate of Lviv, led by Archbishop Volodymyr Sterniuk, the head of the UGCC - High Archbishop and Cardinal Myroslav-Ivan Liubachivsky was in Rome. On February 3-10, 1991, the last out-ofUkraine Synod of the entire hierarchy of the Church, with the participation of bishops from Western Ukraine, gathered in the Vatican. They discussed the situation in Ukraine and decided to move the Head of the UGCC to Lviv ${ }^{488}$. Already on March 30, Metropolitan M. Liubachivsky arrived at the historical centre of the UGCC in Ukraine and celebrated the Bishops' Mass in the St. George's Cathedral and on the next day he attended a grand academy where he was greeted by the leaders of the region and thousands of Greek Catholics $^{489}$.

\footnotetext{
486 «Вірю, що усі з’єднаємося у Христі»: Інтерв’ю 3 Ординарієм ІваноФранківським Владикою Софроном Дмитерком ЧСВВ 3 нагоди його 80-літнього ювілею. Нова зоря. 1997. 27 травня.

${ }^{487}$ Постанова Львівської обласної ради. Людина і світ. 1990. № 9. С. 13.

${ }^{488}$ С тоцький Я. Історичні аспекти відновлення, реорганізації та структурування православних і католицьких церков в Україні у 1988-1999 роках. Київська Церква. Київ; Львів, 1999. № 2-3. С. 54.

489 За вільну Україну. 1991. Червень. Спецвипуск.
} 
The arrival of the Head of the UGCC in Ukraine and his approval on the St. George's throne marked the final legalization of the Church, the end of the catacomb existence and the beginning of a new era in its history. The long-standing struggle of the Ukrainian people for the revival of the national Church ended with victory.

On April 23 of that year, the Verkhovna Rada of the UkrSSR adopted the Law "On Freedom of Conscience and Religious Organizations", which regulated one of the most important problems of the ethnic and national development of society. Finally, all bans on religion and ecclesiastical organizations were lifted and citizens of the republic were legally granted the right to freedom of conscience and religion, the interests of believers and religious organizations were combined with the interests of the state ${ }^{490}$.

Thus, religion acquired a new social status, filled with ethnonational content. This was a period of radical rethinking of the role and place of religion in society and the state, the return to the people's life of the rites, customs and historical traditions of national spirituality. Some legislative acts in Ukraine recognized such religious holidays as Christmas, Easter, Trinity.

On July 16, 1990, in a deep crisis of the totalitarian regime and the collapse of the USSR, after a fierce struggle between the democratic and communist parliamentary blocs, the Verkhovna Rada of the UkrSSR adopted the Declaration of State Sovereignty of Ukraine ${ }^{491}$, which proclaimed "the rule, autonomy, completeness and indivisibility of the power of the republic within its territory, and independence and equality in external relations!". The attempt of the Kremlin military-party bureaucracy through a coup d'etat on August 19-21, 1991 to save the communist empire ended in failure and accelerated the final collapse of the USSR. On August 24, an extraordinary session of the Verkhovna Rada adopted the Resolution and the Declaration of Independence of Ukraine. Ukraine has become an independent democratic state with an indivisible and inviolable

\footnotetext{
490 Закон України «Про свободу совісті та релігійні організації». Відомості Ради УРСР. 1991. № 25. С. 656-666.

491 Зайцев О., Зайцев Ю. На шляху до незалежності. Історія України. Вид. 2-ге. Львів: Світ, 1998. С. 407.
} 
territory with only its own constitution, laws and regulations of the government $^{492}$.

With the proclamation of independence, UGCC believers, along with the believers from other denominations, were given the opportunity to perform their rights, both religious and national-state. However, in the sphere of ecclesiastical relations Ukraine received the complex inter-denominational relations from the communist regime. There were many obstacles to the religious revival in general, and the restoration and reconstruction of the UGCC in particular. In those days, there were three major, most numerous Christian churches in Ukraine: the Ukrainian Orthodox Church, headed by Metropolitan Filaret (5 031 religious communities), subordinated to the Moscow Patriarchate as an autonomy, Ukrainian Greek Catholic (1912 Communities) led by Patriarch and High Archbishop Cardinal Ivan Myroslav Liubachivsky and Ukrainian Autocephalous Orthodox Church led by Metropolitan Mstyslav (811 communities) ${ }^{493}$. The appearance in the arena of the religious life of the Ukrainian national churches of the UGCC and the UAOC significantly narrowed the influence of the Russian Orthodox Church, that is, its exarchate of the UOC. The Ukrainianization of the religious and ecclesiastical sphere did not suit Moscow at all, and the hierarchy of the Russian Orthodox Church strongly committed obstacles in the development of national churches. In addition, there were no friendly relations between the hierarchs of the UGCC and UAOC who tried to establish themselves in Western Ukraine and struggled for influence. However, inside the complex inter-denominational processes, sometimes through sharp inter-denominational conflicts, the UGCC has demonstrated a truly record-breaking tempo of its revival and development. It should be noted that the revival of ethno-national and religious life in the western region of Ukraine took place in the conditions of taking of power structures by national patriotic forces. In particular, in the Lviv, Ternopil, Ivano-Frankivsk regions the executive bodies were headed by the representatives of the Movement. In the elections to the Verkhovna Rada of Ukraine, the democratic bloc won in five oblasts: Lviv (all 24 Movement candidates), Ivano-Frankivsk, Ternopil,

492 Ibid. C. 433.

493 Людина і світ. 1991. № 5. С. 41. 
Volyn, and Kyiv ${ }^{494}$, which were forced to pursue their policies in the religious sphere on the principles of religious pluralism.

The persecution of the Ukrainian Greek Catholic Church by Communist Party, liquidation of its organizational structures as well as educational institutions, long-standing information blockade and other repressive measures by the Soviet authorities, imperial activities of the Moscow ROC, caused a number of problems, that were facing hierarchs and clergy to revive the national church. The most important among these were the general aspects of national-spiritual revival, raising the role of religion in the spiritual life of society, establishing the place of lay people in the process of state-building, the consolidation of ethnic groups in independent Ukraine.

First of all, it was necessary to restore and improve the organizational structure. In general, the UGCC came out of the underground being structured. It had an extensive network of parishes, underground seminaries, which filled the priesthood ranks, the centers of monastic life, and, most importantly, a big amount of faithful lay people. At the time of the legalization of the UGCC, there were three eparchies: Lviv, Ivano-Frankivsk and Mukachevo, which was directly under the control of the Vatican. The of Lviv and IvanoFrankivsk eparchies constituted the Metropolitanate of Lviv, which was headed by Archbishop Volodymyr Sterniuk before the arrival from Rome the Head of UGCC ${ }^{495}$.

With the active participation of the Lviv, Ivano-Frankivsk and Ternopil communities, Greek Catholic structures were being built in the east of the country, including the capital. In 1991, the Kyiv State Administration passed to Greek Catholics the Church of St. Nicholas on the Askold's Grave. Among the founders of the community were artist Nina Boyko, professor of architecture Larysa Skoryk and other well-known scientists, politicians and artists. According to the first parish priest, Ihor Onyshkevych (Order of St. Basil the Great), this church "should become a temple of prayer for all who gave their lives

\footnotetext{
494 Зайцев О., Зайцев Ю. На шляху до незалежності. Історія України. Вид. 2-ге. Львів: Світ, 1998. С. 406.

${ }^{495}$ Стоцький Я. Історичні аспекти відновлення, реорганізації та структурування православних і католицьких церков в Україні у 1988-1999 роках. Київська Церква. 1999. № 2-3. С. 54.
} 
for the freedom of Ukraine, sacrificed themselves for the Church of Christ" and therefore "has become the throne of Christian martyrs" After his arrival in Ukraine, the High Archbishop Cardinal Myroslav Ivan Lubachivsky in May 1992 called the first after 1946 Synod of Bishops on the Ukrainian soil. 28 bishops from Ukraine and the diaspora came to Lviv to discuss the urgent problems of building the Church. As a significant achievement there was marked the increase of number of Greek Catholic communities up to 2700 , restoration of the 33 monasteries and 5 religious schools ${ }^{497}$.

One of the painful problems in the process of building the Church was the lack of high-level priests training. Indeed, according to 1996 statistics, the situation with the clergy, their experience and education was difficult. In particular, in the Sambir-Drohobych diocese of 184 priests 108 were from the spiritual institutions of independent Ukraine, 65 were transferred from the Russian Orthodox Church, and only 11 parishioners who left the underground, were educated and ordained before 1946, or trained in underground seminaries ${ }^{498}$. The situation in the Ternopil Eparchy was even more complicated at this time, where out of 226 priests, 160 , or $70 \%$, were young people who came from the revived seminaries. 53 parishioners passed from Orthodoxy and 13 came from the underground ${ }^{499}$. The diversity of priesthood training, the heterogeneity of their education and work experience have adversely affected the overall condition of the Church.

It should be noted that the Consistory of the Metropolitanate together with the hierarchs of the Church in Ukraine and the diaspora, tried to improve the situation in this area. In 1994, the Theological Academy was restored in Lviv and enrolled 127 of its first students. Five institutes operate at the academy ${ }^{500}$. Among them is the Institute for the History of the Church, the first non-governmental scientific institution to investigate the situation of the Church under the

\footnotetext{
496 Онишкевич Ігор Ілля «Ми молемося за єдність українських християн...». Нова зоря. 1993. Вересень. Ч. 35-36.

497 Людина і світ. 1992. № 11-12. С. 43.

${ }^{498}$ Ibid. 1992. № 11-12. C. 11.

${ }^{499}$ Ibid. C. 15.

${ }^{500}$ Ibid. 1998. № 10. C. 27.
} 
conditions of a totalitarian communist regime. Its activity is based on the method of "living history", which means the collection of oral testimony and their computer analysis. The Institute publishes a digest of church history "The Ark" (Part 1, 1993; Part 2, 2000) organized a series of "Brest readings", prepares collections of documents $^{501}$. There is also a Training Institute at the academy where priests deepen religious knowledge.

In 1994, the Institute of Higher Religious Culture at the University of Lublin (Poland) was opened for Greek Catholics, where in 1996 250 students - priests, monks and nuns - studied, 45 of them completed a two-year course and received diplomas ${ }^{502}$. All these measures have undoubtedly changed for the better the staffing situation in the short time of the Church's reconstruction process. A total of 1678 future priests were educated in eight educational institutions of the UGCC in $1994^{503}$. Improvement of this sphere continues. Within the Church there is also a hospital named after Metropolitan Andrey Sheptytsky, radio "Voskresinnya", the TV channel "Sobor" TV, the publishing houses "Missionary", "Svichado", "Nova Zorya" and others.

The celebration of the 400th anniversary of the Union of Brest was a powerful impulse for raising the authority of the UGCC and its further development. Major anniversary events took place in Rome, led by Pope John Paul II, with the participation of all Greek Catholic hierarchs and cardinals, archbishops, bishops of the Latin Church. At the opening of the Synod of Bishops of the UGCC in the Apostolic Capital on 16 November 1995, the Apostolic Letter of the Pope on this historic date was published ${ }^{504}$. In a speech at the Synod of Bishops of the UGCC, referring to the Ukrainian hierarchy, the Pope called: "Worthy Brothers! The upgrade process - and you know it well - will be long and will require patience and resilience, but it will

\footnotetext{
${ }^{501}$ Інститут історії Церкви Львівської богословської академії. Львів, 2000. 20 с.

502 Документи патріаршого Собору Української Греко-Католицької Церкви. Перша сесія. Жовтень 1996 рік. Львів: Свічадо, 1998. С. 5.

${ }^{503}$ Головащенко С. Історія християнства. Київ: Либідь, 1999. С. 300.

${ }^{504}$ Католицький щорічник 1996. Київ, 1996. С. 8-10; Місіонар. 1996. № 13. С. 8-9.
} 
surely bring the expected results.You are on the right way. Continue to finish what you started" $" 505$.

The main celebrations of the Brest Jubilee in Ukraine took place in October 1996. At the altar in the square, near the Opera House in Lviv, Cardinal Myroslav Ivan Lubachivsky celebrated the Holy Liturgy. A solemn academy was held at the high-level in Opera House, announcing congratulations from the Government of Ukraine and honorable guests. They expressed recognition of the historical merits of the Greek Catholic Church for the Ukrainian people and the national-patriotic, state orientation of its activities during the period of struggling for independence of Ukraine, the revival and development of the Church $^{506}$.

At the same time, in October 1996, Metropolitan Cardinal M. Lubachivsky called the Council of the UGCC. It was attended by all hierarchs of Ukraine and diaspora who reported on the activities of eparchies and exarchates. Initially, the main slogan of the Council was: "Moral and Spiritual Revival of Ukraine and Ecumenism"507. On behalf of the Government of Ukraine, the Council was first congratulated by the Chairman of the State Committee for Religious Affairs of Ukraine A. Koval ${ }^{508}$.

The Patriarchal Council of the UGCC in 1996 also noted the progress in the revival and development of the monastic orders, whose activity in Ukraine was traditional until the ruins of the 1940s. The most numerous and influential was the Order of St. Basil the Great, which up to 1939 consisted of three provinces (Galician, Transcarpathian, and overseas American-Canadian), had 49 monasteries and 650 monks. On the lands of Ukraine the communist regime closed and appropriated all monasteries (31), most of the 350 monks were repressed ${ }^{509}$. Following the legalization of the UGCC, 17 monasteries have been returned to the Basilians in

\footnotetext{
${ }^{505}$ Ibid. C. 30.

506 Сапеляк А. Київська Церква на слов'янському Сході. Буенос-Айрес; Львів, 1999. С. 212-213.

507 Документи патріаршого Собору Української Греко-Католицької Церкви. Перша сесія. Жовтень 1996 рік. Львів: Свічадо, 1998. С. ХІ-ХІІ.

508 Ibid. C. XXI.

509 Людина $і$ світ. 1998. № 10. С. 27; Львівська богословська академія. Львів, 2000. $90 \mathrm{c}$.
} 
Ukraine, which fully resumed their pastoral work, and are serving 62 parishes and about 250 affiliated churches and missions in 9 villages in eastern Ukraine ${ }^{510}$. The great importance for the Church had the renewed Basilian publishing office established by Metropolitan Andrey Sheptytsky in 1898. Thanks to the Western Diaspora, the Basilian printing house in Zhovkva was modernized and in a short time published hundreds of books of religious content $^{511}$. Therefore, for a short period, as early as the mid-1990s, the Greek Catholic Church solved the problem of structuring and come to the Christian world with a grand structure with a large-scale religious life and a well-developed national-state ideology. It, having a great influence on the laity of the western region of Ukraine, conquered supporters in the east and gained an important place in society.

\footnotetext{
${ }^{510}$ Інститут історії церкви Львівської богословської академії. Львів, 2000. 20 с.

511 Документи патріаршого Собору Української Греко-Католицької Церкви. Перша сесія. Жовтень 1996 рік. Львів: Свічадо, 1998. С. 29.
} 


\section{PART 7. \\ THE UGCC IN THE SYSTEM OF STATE-CHURCH RELATIONS IN UKRAINE}

The revival of Ukraine's independence has caused a wave of national and religious exaltation, a rethinking of the Church's role in developing the nation-state ideology of a society that has freed itself from the influence of a totalitarian system. The spiritual basis of the state-building process is the Ukrainian national idea, which consolidates the nation to solve complex problems of revival. The Church has played a decisive role in this area in the history of Ukraine for centuries. "Uniqueness and universality of the Christian Church as a factor of state-making activity of the Ukrainian people," stresses the UAOC Archbishop Ihor Isichenko, "in the period of state revival ensures the preservation of ethnonational identity, promotes the consolidation of society, acts as a guarantor of the nation's presence in the world Christian civilization" sovereign state is connected with the affirmation of ideological unity and national consciousness of the Ukrainian people as necessary factors for achieving the state aspirations.

The UGCC's unwavering position on this issue was supported by the Second World Forum of Ukrainians, which took place in Kyiv in August 1997 with the participation of the President of Ukraine Leonid Kuchma, delegates of the Ukrainian world community and representatives of the national Churches. In his speech, L. Kuchma emphasized that the Ukrainian people must deeply understand the national idea, to form and adopt a national-state ideology, in order not to turn off the chosen path of independence ${ }^{513}$. The documents of the Forum stated that "revival and strengthening of independent national Ukrainian state on ancient ethnic Ukrainian lands" requires, above all, "the revival of the national, state consciousness of the Ukrainian

512 Ісіченко Ігор, владика. Виступ на науковій конференції. Визвольний шлях. 1995. № 11. С. 1301.

${ }^{513}$ Визвольний шлях. 1997. № 10. С. 1169. 
people... without this the Ukrainian independent state would be a ghost". The resolution also emphasized: "The Ukrainian national idea, which is able to unite all citizens of Ukraine.., to serve the preservation and strengthening of Ukrainian statehood, should be a purposeful formation of civil society in Ukraine" ${ }^{\text {. }} 14$.

The formation of national-state ideology is closely connected with the problem of the relationship between the Church and the state, which has deep historical roots. In this context, the positive role of the Christian Church of Volodymyr the Great in the consolidation of the Ukrainian ethnic group and the strengthening of the state of Kyivan Rus-Ukraine should be noted. The Orthodox Church of the Cossacks and Khmelnytsky period took part in the national liberation movements of the Ukrainian people and the development of the state. But in the conditions of loss of statehood, after 1686, when the Metropolitanate of Kyiv passed under the authority of the Moscow Patriarchate, it has become an instrument of anti-Ukrainian forces and no longer carried the Ukrainian national idea. Therefore, only the Greek Catholic Church, through the Union of Brest, managed to preserve national identity, to implement the Ukrainian church policy, to continue the struggle for the realization of the Ukrainian national idea and statehood in the conditions of statelessness, expansion of the Western and Eastern Churches. It played a significant role in the era of national revival in Galicia in the second half of the nineteenth century, as it was noted in the previous sections of this paper. "In Galicia in the nineteenth and early twentieth centuries," said Lyubov Kiyanovska, "it was the priests who awakened the consciousness of their Nation in the Ukrainian people, and established such important public institutions as schools, theaters, and scientific centers, - this phenomenon does not exist in any country in Europe. On this background, the most important place belongs to Metropolitan Andrey Sheptytsky"515.

National-state aspects in the activities of the Ukrainian GreekCatholic and Orthodox (first of all autocephalous) Churches in the era of liberation struggle of 1917 - 1920 aimed at realizing the natural

\footnotetext{
514 Визвольний шлях. 1997. № 10. С. 1175.

515 Кияновська Л. Пам’яті митрополита Андрея Шептицького. Київська Церква. 1999. № 6. С. 133-134.
} 
right of the Ukrainian people to statehood in the form of the UPR and ZUNR, raising the national consciousness of the Ukrainian ethnos and the role of the Church in these processes. In his speech at St. Peter's Church in Rome on the occasion of the 50th Anniversary of the First November Breakdown of 1918 in Galicia Major Archbishop of the UGCC, Cardinal Josyf Slipyj emphasized: "The purpose of the Ukrainian people on earth is to fight for the Ukrainian state, for the Christian state of their nation". Remembering the restoration of an independent Ukrainian state - ZUNR, he said: "It was a powerful act that we imposed on the glorious earlier times of Svyatoslav, Volodymyr, Yaroslav, Daniel and others and began to think their statesmen's thoughts. Our Ukrainian people have once again joined the ranks of free nations and the family of independent states... This act was blessed by our Church because it prayed for it for the creation of our own state, for its approval and for its construction... The idea of rebuilding the Ukrainian state must be leading in all our thoughts, struggles, sufferings and achievements. Let the raised state flag of the United Ukraine flutter over all of us forever!" Meanwhile Galicia in a newly formed in November 1918 state had its own national UGCC, the UPR raised the question of a church independent from Moscow. "No matter how successful in the future our achievements will be in the plane of political struggle," wrote S. Petliura, "the whole idea of our state independence will be blocked "in the hands and feet" by this dependence in the ecclesiastical plane, striking and undermining the independent struggles of our nation"

Relations between the Ukrainian Orthodox Church and the restored nation state of the UPR were fully in line with the situation that means that the Church supported it with all possible social and moral measures. The greetings of the Orthodox clergy to S. Petliura in March 1921 stressed that the close unity of Church and state is based on the national-state concept of the UOC, which together with the people is fighting for the freedom of Ukraine. "The close union of the state and the church," it was stressed in the greeting, "is the only condition of our national and state life" $" 517$.

516 Петлюра С. Статті. Київ, 1993. С. 213.

${ }^{517}$ ЦДАВО України. Ф. 1072, оп. 1, спр. 3, арк. 159. 
It should be noted that the hierarchs of the Orthodox Church, and especially the Minister of Religions of the UPR I. Ohienko and later Metropolitan Ilarion, followed conceptual view that in the conditions of independent state there should be an independent national church, that is autocephalous. This idea is best described in a letter of the head of Ukrainian Orthodox Church Council to the head of Directory on May 25, 1920. 'Ukraine's statehood will only have a solid foundation when the Ukrainian people will have their own, completely independent national church..," the authors of the letter stressed. "The goal of this movement has been and now is only one: approval of the united autocephalous Ukrainian national church, which, at the same time, should be one of the main pillars of the statehood of the Ukrainian people"518.

Thus, the UOC hierarchs tried to get rid of dependence on the Moscow Patriarchate and Russian church centralism, to carry out democratization, celebrate liturgies in the Ukrainian language using the example of the UGCC, to revive national customs, rituals and traditions declared by the UNR decree on autocephaly. Indicative phenomenon at that time was the rebellion of Orthodox communities in Vinnytsia in the summer of 1920, which asked S. Petliura to send the pro-Russian bishops Amvrosiy and Pymen to Bolshevik Moscow because they issued an order "to prevent any Ukrainianization of the church at all costs". Believers asked to establish the UAOC in order to "educate the Ukrainian people in the national spirit and go toward the autocephaly of the Ukrainian Church" ${ }^{, 19}$. It should be noted that not all bishops supported these views of the unity of the Orthodox Church and the state in the state-forming process of the UNR, as well as the Ukrainian state of Hetman P. Skoropadsky. Minister of Religions of the Hetman's Government O. Lototsky, acknowledging the ideas of autocephalousness, stressed the clear delineation of the functions of the state and the church toward limiting its interference with secular affairs. The UAOC First Hierarch V. Lypkivsky found it impossible to identify a nation with an Orthodox religion because the Ukrainian nation is a political, territorial and state, but not a religious

\footnotetext{
${ }^{518}$ ЦДАВО України. Ф. 1072. Оп. 1. Спр. 3. Арк. 12.

519 Рибачук М. Ф., Уткін О.І., Кирюшко М. І. Національне відродження і релігія. Київ, 1995. С. 8.
} 
concept $^{520}$. V. Lypynskiy made a profound contribution to the concept of the relationship between the Church and the state in his research "Religion and Church in the history of Ukraine". First of all, he rejects the concept of state church and clearly defines the areas of activity of the Church (spiritual) and the state (material), defines the important role of the Church in the struggle for the statehood, calls the national and Ukrainian the Church, which "will be able to teach its believers in their struggle for the Ukrainian state to fulfil the

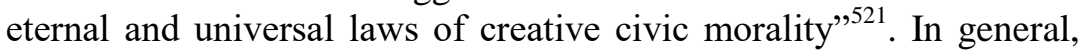
the concepts of Ukrainian Orthodoxy in the era of liberation struggles concerning the state formation, the Church's participation in the economic, cultural, educational programs of the state was not sufficiently substantiated and did not influence the state-making process. While the UGCC, even in the conditions of statelessness, not only developed its national-state doctrine, but also created the material basis for the implementation of its ideas in the form of national, cooperative, scientific, cultural and educational organizations, and most importantly, in the grand structure of the national Church.

Let us briefly consider the national-state views of Metropolitan A. Sheptytsky. It is known that at the beginning of the XIX century among the Greek Catholic clergy in Galicia there appeared a widely educated, interested not only in their Church but, above all, in the national interests of the Ukrainian people, leaders, who contributed to the development of the Ukrainian national idea through their activities. Metropolitan Andrey Sheptytsky made the most significant contribution to the formation of the national-state ideology of the UGCC, who for almost half a century of modern Ukrainian history was a leader of the Church and a spokesman for the interests of the Ukrainian people and secular national life. His merits in combining church interests with national ones are highly appreciated by domestic and foreign scientists. The leading position in the society of Metropolitan was provided by his unwavering desire to devote his life and activity to the Ukrainian people, which he has repeatedly expressed and implemented in everyday life, as well as the level of

${ }^{520}$ Ibid. C. 9.

521 Липинський В. Релігія і церква в історії України. Київ, 1995. С. 11. 
scholar of the European dimension. He has written numerous religious and secular scientific papers and has brought together the most famous scholars in Galicia, among them were theologians J. Slipyj and P. Filyas, historians I. Krypiakevych and I. Skruten, art critic I. Svientsitski, archeologist J. Pasternak, lawyer R. Kovshevych, philosopher M. Conrad and other representatives of the Ukrainian scientific elite who made a significant contribution to the development of the national idea.

"With the coming of Bishop Andrey to the Metropolitan throne of Kyiv-Galician in 1900," noted the scientist from Lviv Mykhaylo Haykovsky, "at the head of the Church and the nation appeared a person who contributed to the spiritual and national revival of Ukraine, especially Galicia, and brought the humiliated by AustriaHungary and Russia Ukrainian people into the European and into the world political arena. Since his arrival the regeneration process of the statehood revival of Ukrainian nation started in Galicia"522. His activity was based on a deep understanding that in Ukraine the fate of the people and the Church are inextricably connected. The Christian religiosity of Ukrainians has been long ago recognized as a phenomenon in the world society.

Devoting his life and work to the interests of Ukrainians, Metropolitan A. Sheptytsky developed a strong national-state doctrine of the Greek Catholic Church. First of all, we should note his "Memorandum on the future structure of the Ukrainian state" of August 1914 after the Austrian troops occupy the territory of Ukraine controlled by Russia. Referring to the Austrian government, he wrote: "We need to solve the triple problem: the military, legal and church organization of the region... in order to alienate these regions as far as possible from Russia and to make this national area attractive to the population and independent from Russia. For this purpose, all traditions of Ukraine, suppressed by Russia, should be used and so firmly revived in the minds of the masses that no political

522 Гайковський М. Сучасне і майбутнє України: думки дивізї митрополита Андрея Шептицького. Київська Церква. 2000. № 1(7). С. 44. 
combination would be able to destroy the consequences of our victory" ${ }^{\prime \prime 23}$.

As for the military organization in the Ukrainian territories, Metropolitan considered it necessary to build it on the tradition of Zaporizhzhya Cossacks, create a Ukrainian army with all national outward signs and spirit. This should have contributed to the development of the national movement in the Russified, denationalized region. According to Metropolitan, it was advisable to revive the institution of Hetman ${ }^{524}$. He proposed to radically destroy the Russian state system and its imperial legislation, to implement Austrian laws, taking into account the peculiarities of the Ukrainian national mentality, which would immediately involve Ukraine in the European legal space ${ }^{525}$.

In the case of church organization, Metropolitan considered first of all to "separate as far as possible the Ukrainian Church from the Russian Church.., to separate the clergy from political and police activity on purely church and Christian area". He stressed that in the Ukrainian state a national church should be preserved with its traditional rituals, customs, which constitute the spiritual values of the nation, without any influence of Moscow. Thus, a "perfect plan for the reorganization of the Ukrainian Orthodox Church was developed," rightly observes M. Haikovsky, "which did not affect the canonical foundations of either the Orthodox or Catholic Churches, but put it in the rank of self-governing autocephalous Churches",526.

Thus, at the beginning of the First World War Metropolitan A. Sheptytsky proclaimed the nation-state aspirations of the Ukrainian people and outlined a strategic plan for development of the state, which was based on a strong foundation: the national army, the European legal field, and the Ukrainian Church. It is for these views that the Russian authorities after the occupation of Galicia intensified

523 Государственный архив Российской Федерации (ГАРФ). Ф. 102. Оп. 1. Спр. 131. Арк. 109.

524 Государственный архив Российской Федерации (ГАРФ). Ф. 102. Оп. 1. Спр. 131. Арк. 110.

525 Ibid

526 Гайковський М. Сучасне і майбутнє України: думки дивізії митрополита Андрея Шептицького. Київська Церква. 2000. № 1(7). С. 45. 
their attack on the UGCC. A report from the Police Department was found in one of the archives in Moscow, which stated that in the national movement for the "rejection of the whole Ukraine from Russia... the Uniate clergy under the leadership of Metropolitan Sheptytsky has played an important role in the last decade" ${ }^{, 527}$. The state ideas of Metropolitan were partly realized with the formation in November 1918 of the Western Ukrainian People's Republic. He personally participated in the process of its formation and development, was together with the bishops H. Khomyshyn and J. Kotsylovsky a member of the Ukrainian National Council representative body of the Republic.

The Head of the UGCC sincerely welcomed the proclamation of the Act of the restoration of the independent Ukrainian state on June 30, 1941. In a pastoral letter to the clergy and the believers on July 1, 1941, he wrote: "A New Era began in the life of the State United Independent Ukraine... Ukrainian People must show in that historical wave that they have a sufficient sense of authority, solidity and vitality to earn a position among the nations of Europe in which all God-given power could be developed" ${ }^{\text {"28 }}$. In another pastoral letter from July 5, Metropolitan appealed: "All who feel themselves Ukrainian and want to work for the good of Ukraine... let them work in unity and harmony to rebuild the economic and cultural life, destroyed by the Bolsheviks. Then in God's hope, that on the foundations of solidarity and hard work of all Ukrainians, United Ukraine will rise not only as a great word and idea, but as a living, viable, healthy, powerful state organism" ${ }^{, 529}$. It is well-known that these hopes of the head of the UGCC and of the whole Ukrainian people did not come true: independent Ukraine did not fit into the geostrategic plans of both J. Stalin and A. Hitler. German occupation authorities launched a widespread attack on the Ukrainian national movement, repressing its members. In these extremely complex and difficult conditions for people under German occupation and the

\footnotetext{
527 Митрополит Андрей Шептицький: Життя i Діяльність. Документи i матеріали 1899-1944. Т. ІІ. Церква і суспільне питання. Кн. 2. Львів, 1999. C. 639.

${ }^{528}$ Митрополит Андрей Шептицький: Життя і Діяльність. Т. І. С. 517.

${ }^{529}$ Ibid. C. 518.
} 
Great War, Metropolitan A. Sheptytsky, being already ill, at the end of his life worked out and left a document that summarized the national-state thought of the Greek Catholic Church in the midtwentieth century. It is a decree to the clergy "The Ideal of Our National Life" known by another name "How to Build the Native Home?" written in December 1941 and approved by the Archdiocesan Council in 1941.

First of all, it defines the state-unification desire of the faithful: "The ideal of our national life is our native all-national HutFatherland" and prophetically says: "Divine Providence will enable the Ukrainian people to fulfill their natural right that is to choose and set up the control over their Native Hut" ${ }^{\prime 530}$. The following chapters of this deeply scientific paper outline what should be the Ukrainian state-Homeland - above all - powerful, monolithic and able to "combat different tendencies of internal disintegration and successfully protect the borders from external enemies" and most importantly, provide "true and sustainable happiness for citizens" that will contribute to the necessary condition of state formation - the consolidation of society from family and community to sociopolitical communities, societies, associations, cooperatives, unions "connected by a strong ties of solidarity" 531 .

Bishop also advised the constructors of the Ukrainian state to analyse more deeply the principles of national life, to gain a thorough knowledge of the laws of its development "and to our people, even if only to the faithful should be transfered the necessary knowledge and educate them in all those social virtues on which the value of the whole public work of the person depends" ${ }^{, 532}$. The concept of Metropolitan A. Sheptytsky regarding the state leadership of Ukraine looks more modern. He believes that only the people should choose, in particular "by plebiscites or referendums the form of authority: monarchical, oligarchic or democratic. Each of them serves primarily the interests of the people, "establishes righteous laws that conform to God's law and the common good and impartial and independent judging", provides freedom of a person, participation in government

\footnotetext{
${ }^{530}$ Ibid. C. 519.

${ }^{531}$ Митрополит Андрей Шептицький: Життя і Діяльність. Т. І. С. 520.

532 Ibid. C. 521.
} 
of as many citizens as possible. At the same time, he analyses the existing state systems, in particular, monarchical, republican and totalitarian, warning "not to follow false slogans of revolution and socialism, leading to anarchy, slavery, poverty and ruins"533.

Metropolitan exposes the Soviet totalitarian system with significant arguments "in which a dictator and party or monoparty (Stalin) has power.., considers himself competent to enter into all the smallest details of life of the units, wants to regulate everything, takes everything in its hands and leaves no freedom to the units"534. By the way, Ivan Franko gave the same assessment of the state of the socialist system, who called it "a huge people's prison", where executives concentrate "in their hands such enormous power over the lives and destinies of millions of their fellows that the greatest despots never had"535. However, Metropolitan A. Sheptytsky realistically evaluated the democratic systems of the West, did not hide their disadvantages, in particular, the demagogic nature of the declared and not always realized social promises, but comparing them with the totalitarian regimes of Nazi Germany and Bolshevik Russia, he concluded: "Tyranny is most harmful because under unjust authority, the more unity it has, the more it harms the people", and "democracy and freedom... can provide the people with peace, prosperity and happiness" $" 536$.

The head of the UGCC fought for the unity of the Ukrainian people and the Ukrainian Churches, which, unfortunately, he noted, "in religious life are divided as our people". In his view, the unity and power of the state to a large extent depended on the educational work of the clergy, on the Church in general, which played an important role in the system of formation of the moral values of the faithful, their national identity and statehood thinking. Then he described the large and important tasks for the clergy, the requirements in their pastoral work. Other factors influencing the formation of the nationalstate ideology of the Ukrainian ethnic group are also distinguished: family, community, voluntary organizations and societies. At the

\footnotetext{
${ }^{533}$ Ibid. C. 77.

534 Ibid.

535 Франко I. Твори в 50 томах. Т. 45. - С. 341-342.

536 Шептицький Андрей, митрополит. Як будувати Рідну Хату? ... С. 5.
} 
same time, it is noted that their positive role depends on how freely they act, "enjoy full freedom and have some established traditions". Therefore, the Ukrainian state should consider their freedom as "the most important thing" 537 .

"Taking care of the fate of Ukraine," notes the famous religious scholar Anatoliy Kolodnyi, "accompanied all the conscious life of Metropolitan Andrey - from God's call to become a Basilian monk to the last breath" ${ }^{, 538}$. And it is hard to disagree with this thought.

Let us consider the participation of the UGCC in the process of establishing of Ukrainian statehood. Describing the significance of the Church in state processes in Ukraine, we must remember that the socio-political and economic aspects of social life are closely linked to religious ones. An attempt by the Communist regime during 70 years to move the Church out from public life, or eliminate it totally, as it happened with the Ukrainian national Churches, was useless. After Ukraine's declaration of independence, the Church's influence on society has increased significantly, its nation-state ideology has been recognized because it corresponds to the demands of the time. Church-state relations are being transformed because modern political, economic and cultural processes, as Kyiv political scientist and religious scholar Serhiy Zdioruk rightly points out "cannot be resolved without taking in consideration the religious movements and church groups... Ukraine will not be able to effectively organize its security and implementation of national interest until the Ukrainian Church as the National Church standing on guard against the spirituality and morality of the Ukrainian nation will not take its proper place" ${ }^{, 539}$.

As already noted, the religious life of Ukrainian people in the XX century experienced devastating destruction. The first blow after the October 1917 Bolshevik coup was inflicted with Lenin's decree of February 2, 1918 about separation of church from the state and school, which was condemned by the ROC All Russian Local

\footnotetext{
${ }^{537}$ Митрополит Андрей Шептицький: Життя і Діяльність. Т. II, кн. 1. С. 528.

538 Колодний А. Андрей Шептицький про будівництво рідної хати. Київська Церква. 2000. № 1(7). С. 49.

539 Здіорук С. Національна церква у контексті державотворення в Україні. Розбудова держави. 1994. № 1. С. 56.
} 
Council as the beginning of the persecution of the Church. VIII Congress of the Bolsheviks in 1919 decided to attack "religious prejudices" and the resolutions of the Party and Government of the USSR in 1929 launched a complete destruction of the church, in particular the elimination of the UAOC and the mass repressions of the clergy. Restored under the German occupation UAOC, as well as UGCC - the national churches of Ukraine, were liquidated as collaborative and hostile to the Soviet regime. Despite the loyalty to the totalitarian system, the ROC was constantly oppressed. The CPSU, as the ruling party of militant atheism, considered inviolable duty of every Communist and nomenclature activist to take part in the fight against religion. It was only after 1985 during Gorbachev's reforms of political power, the liberation of the regime and a positive change in church-state relations began. The most important of these were the revival of the Ukrainian National Churches of the UGCC and the UAOC that made a significant contribution to Ukraine's independence. Sociological research of the Department of Religious Studies of the Institute of Philosophy of NAS of Ukraine confirmed that before the historic People's Referendum on December 1, 1991, approximately 97.4 percent of Greek Catholics and 96.9 percent of UAOC representatives supported the idea of independence of the Ukrainian state ${ }^{540}$. Chairman of the State Committee on Religion V. Bondarenko wrote: "It should be noted that since the first days of its revival the UGCC has again become an important factor in social development. Therefore, the West of Ukraine as a region of developed culture played a significant role in the revival and development of the young Ukrainian state" ${ }^{\text {"541. }}$.

We should note that after 40 years of deep underground persecution, Greek Catholic Church continued to generate Ukrainian national-state ideas and was fighting for civilized state-church relations. In the discussions of the Second Vatican Council in 1965 on "Declaration on religious freedom" Cardinal J. Slipyj, bishop A. Roboretsky and other Greek Catholic hierarchs made a number of proposals for this document. It regulated relations between the state

\footnotetext{
${ }^{540}$ Шуба О. Релігія в етнонаціональному розвитку України. Київ, 1999. С. 161.

541 Бондаренко В. Українська держава: співпраця на новому етапі. Людина i cвim. 1998. № 7. С. 26-27.
} 
and the Church, in particular it proclaimed the right of a person to freedom of religion and limited state intervention, strongly condemned the prohibition of religion, the right of parents to raise their children according to religious beliefs, etc. ${ }^{542}$.

The democratic processes that began in 1991 and continue in Ukraine today, according to O. Shuba, "found their expression in ethno-national and religious-church spheres. Stormy ethno-national and religious revival demanded to put it on the legal line and required the development of appropriate political and legal foundations" ${ }^{, 543}$. The main efforts of the state and the Ukrainian society focused on overcoming the consequences of the previous regimes, first of all in relation to religion, the Church and the believers, the restoration of religious institutions on the level necessary for church life. President Leonid Kuchma in a speech at the All-Ukrainian Christian Forum in 1997, said: "Adoption of the Constitution of Ukraine approved high standards of human rights relating to freedom of conscience and religion. During the years of independence, the state has shown its unwavering desire to cooperate with the Church, strongly supports the service, aimed at strengthening the moral health of the nation"544.

Indeed, overcoming the difficult legacy of the past, Ukraine in the post-totalitarian period has done much to secure the legal status of the Churches and the development of religious life. One of the first laws adopted independently of Moscow was the Law of Ukraine "On freedom of conscience and religious organizations". It is based on the human right to freedom of conscience and religion, the right of parents to raise their children in accordance with their own beliefs and attitudes towards religion. The state took over the duties of overcoming the negative consequences of the past, creating appropriate conditions for the Church. The proclaimed principle of separation of the Church and the State does not reject their close cooperation in all spheres of public life, requires mutual work and responsibility. It should be noted that in the course of state building

542 Сапеляк А. Українська Церква на Другому Ватиканському соборі. Львів, 1995. C. $162-163$.

543 Шуба О. Релігія в етнонаціональному розвитку України. Київ, 1999.

C. 162-163.

544 Людина і світ. 1997. № 5-6. С. 29. 
and in connection with the adoption of the Constitution, the specified law is being improved. Thus, in August 1996, at a session of the Verkhovna Rada of Ukraine, a draft of the law with the changes into the Law was introduced. In particular, the European Convention on Human Rights has caused this, so as the process of formation and structuring of independent religious organizations, normalization of inter-denominational relations, etc. ${ }^{545}$. In order to implement state policy in the religious sphere, a State Committee on Religious Affairs was established under the Cabinet of Ministers of Ukraine. It collaborates with religious organizations in Ukraine, helps them, together with local authorities, to resolve complex issues of interfaith relations, to ensure the functioning of church structures and to ensure the implementation of relevant state legislative acts. Thus, the state is interested in the full revival of religious life in Ukraine. It relies primarily on the national Ukrainian Churches, in particular the UGCC with its powerful structure and national-state ideology. Because history shows that the ethno-national revival and the rise of the state, the political awakening of the people depends largely on the ideology and practice of the Church. One such positive example was the 1999 presidential election, when most of the electorate, especially in the western region with its high religiosity, supported the candidate statesman Leonid Kuchma.

It should be noted that Ukrainian political parties who are on the state's position support the national-state ideology of the UGCC. Among them there are right-wing, center-right parties and the OUN. Despite some claims in the Ukrainian political thought that the ideology of Ukrainian nationalists denies the Christian choice and is not based on Christian principles, the facts suggest the opposite. Back to December, 1940 manifesto, the OUN said it was struggling "for human dignity and freedom, for the right to admit openly all beliefs, for the freedom of all religions, for complete freedom of conscience"546. Its leadership argued that the ideology of Ukrainian nationalism, struggle for national and political liberation of Ukraine, construction of an independent united Ukrainian state coincides with

\footnotetext{
545 Людина і світ. 1998. № 2. С. 28-30.

546 Бедрій А. Український націоналізм і християнство. Визвольний илях. 1962. № 1. C. 43.
} 
Christian ideology and the UGCC's aspirations that the Church and religion, in contrast to the policies of totalitarianism, are absolutely necessary values of the nation and the national state. By the way, the OUN opposed the separation of the church and the state, it supported the introduction of religion in schools. It identified only two churches in Ukraine - the Greek Catholic and Ukrainian Orthodox Churches, advocating their unification and further demarcation from Moscow and rapprochement with Rome.

The state policy of the UGCC, the UAOC, and the UOC of the Kyiv Patriarchate has caused outrage from the Communist Party of Ukraine. Its leader Petro Symonenko in the article "The Communists about the church and its role in modern Ukraine" in May 1999 stated that his party does not accept Catholicism in any form. He wrote: "The Catholic West is hostile to the Orthodox geo-cultural space". He claimed that religion of our ancestors is threatened by Catholicism and another source of threat is the uniatism, that is, the UGCC. Communist leader praised Lviv Pseudo Council of 1946, supported its decision to liquidate the UGCC and generally denied Greek Catholics right to exist. The Communist Party stands for the unbreakable unity of the Orthodox Churches of Ukraine and Russia, calls for a fight against the forces that separate the Ukrainian Church from Moscow, and consider Ukrainian Orthodox Church of the Moscow Patriarchate as their ally ${ }^{547}$.

The UGCC continues to treat the formation of national-state ideology as an important area of its social work. In address to the faithful and the people of Ukraine "On the tasks of the Christian in modern society" on March 12, 1999, the bishops of the UGCC emphasized: "Our country will not be saved by the wisest, most just laws or decrees, market reforms or other means if there is not a proper number of citizens who will carry out those prescriptions and measures in good faith" ${ }^{\text {,54 }}$. This reaffirms the social importance of civic peace and civic responsibility for strengthening statehood and establishing a modern Ukrainian nation.

547 Симоненко П. Комуністи про церкву та їі роль у житті сучасної України. Голос Украӥни. 1999. 26 травня.

548 Людина і світ. 1999. № 3-4. С. 33. 
With the development of human society, social problems are becoming more complicated. With the widening difference between rich and poor, city and countryside, with increasing national factors there are contradictions, tensions between communities and social groups. The hierarchs of the Church, the classics of its social thought long before K. Marx and F. Engels created the doctrine of social problems on religious grounds. The founders of Communist ideology K. Marx and F. Engels and their followers, V. Lenin and J. Stalin, proclaimed the only solution to the problem - the division of society into hostile classes and violent revolutions around the world.

To solve the complex socio-political problems that escalated in the era of the Industrial Revolution in Europe and at the turn of the XIX$\mathrm{XX}$ centuries, the Church proclaimed the other paths taught by the Apostolic See. At the end of the 19th century, the first social encyclicals of Pope Leo XIII appeared in the official moral teaching of the Universal Church that answered the social, political and economic problems of the time. In 1891 the encyclical "New Things" was published. The modern historian of the Church Fr. Ivan Muzychka wrote about this encyclical: "In his encyclical, Leo XIII began the modern preaching of the Church on the social issue. He condemned communism, basing his claim on natural human rights and the dignity of the human person, "whom God himself treats with great respect" 549 . Encyclical proclaims that only on the principles of justice, truth, freedom and love complex social problems can be solved. We should note that these and five other social encyclicals of Pope Leo XIII have been immediately translated and published in Lviv among the decrees of the Lviv Provincial Council of 1891 and were used by the hierarchs of the UGCC in their activities in Galicia $^{550}$.

In the era of the great military and socio-political disasters of the XX century, the Apostolic See has repeatedly responded with encyclicals on social problems in difficult circumstances, in particular, after the First World War and the Bolshevik revolution in

549 Музичка I., о. Вступне слово до збірника. Церква $і$ соиіальні проблеми. Енцикліка «Сотий рік». Львів, 1993. С. 7.

550 Додаток до Чинностей і Рішень руского провінціяльного Собору в Галичині, отбувшегося во Львові в р. 1891. Львів, 1897. С. 97-199. 
Russia. It should be noted that the papal social doctrine was developed by eminent hierarchs, among them a prominent place belongs to Head of the UGCC Metropolitan Andrey Sheptytsky. Among the papal encyclicals of this subject it is worth mentioning John XXIII "Pacem in terris", which outlines important aspects of church teaching on relations between states, people, and the political community, the priority of human rights and the individual in general. An important document of the Church on this issue is the Constitution of the Second Vatican Council in 1965 "Gaudium et spes" for the first time addressed to all people in the world. Basing on the text of the Constitution, Pope John Paul II later wrote: "Also in economic and social life we must respect and develop the dignity and fullness of the vocation of the human person as well as the good of the whole community. A human being is truly the center and purpose of all economic and social life" ${ }^{, 551}$.

In a pastoral letter "On the Social Question" (1904) A. Sheptytsky warned that in some matters the socialist doctrine coincides with the church and serves as a deception for the people. At the same time, he criticized socialists who did not recognize human rights to property. They "would like to take away and replace with the common property all that has been acquired, whether with legal inheritance, or with manual labor or intellectual work, or through savings". With this purpose, they "incite the poor against the rich and they set the principle that all private property should be demolished and common property established and given to the representatives of the communities or heads of state". Thus, they "intend to reach the absolute economic and social equality of all people through the demolition of private property". Metropolitan calls the communist theory utopian, because it made a working man "a servant of the public, who has no right to his work of any kind of relations, is forced to work only for the maintenance" 552 . The socialist doctrine, which proclaims and exercises "the power of the state over the family" and

551 Музичка I., о. Вступне слово до збірника. Церква $і$ сочіальні проблеми. Енцикліка «Сотий рік». Львів, 1993. С. 7-8.

552 Шептицький Андрей митрополит. О Квестії Соціяльній. Церква і суспільне питання. Кн. І. С. 147. 
the individual, is also strongly criticized because the state "should only take care of the rights of units".

In contrast to the socialist doctrine, Metropolitan A. Sheptytsky outlined the Church's social teaching, which covered all aspects of the economic order and was based on Christian principles. One of the main conditions for solving social problems he has identified not in a call to the struggle between the classes, proclaimed by Marxists, but in the need to eliminate the "brotherly struggle of the social classes" and follow the law of God which "unites people, because "People are all brothers, naturally they must live not in struggle, but in harmony and love... Capital and labor do not stand in natural contradiction". Metropolitan rejects Marx's economic theory, according to which labor is a commodity. He considers the statement that "labor is a product of value in terms of demand and sales" to be false ${ }^{553}$.

The development of socio-economic thought in Ukraine at the turn of the nineteenth and twentieth centuries was facilitated by the mutual influence of secular and Christian doctrines. "Under the influence of real socio-economic processes the Church ideology was filled with economic ideas and secular economic doctrines, views, and programs have paid more attention to ethical, moral, and human values in the interpretation of the evolution of business forms and its prospects," wrote Stepan Zlupko ${ }^{54}$. Thus, the social orientation of the Church, the practical activities of hierarchs and the priesthood have had positive consequences. However, in addition to Metropolitan A. Sheptytsky, these problems were raised in their writings by other leaders of the UGCC. In particular, the debates between I. Franko and A. Sheptytsky were appreciated by the famous theologian and philosopher Havryil Kostelnyk in his scientific paper "The boundaries of democracy", in which he considered the aspects of equality of people with socialization of property, public freedoms, relations between the state and the Church. He defended the idea that the private and public property complemented each other and have the right to exist. Moreover, he considered it possible to interfere with

\footnotetext{
553 Ibid. C. 167-176.

554 Злупко С. Вплив Енцикліки «Нові справи» на становлення і розвиток християнсько-демократичної економічної думки в Україні Церква $і$ соціальні проблеми. Енцикліка «Сотий рік». Львів, 1993. С. 50.
} 
the state in the sphere of property, to restrict it and to carry out land reforms. "Where, therefore, the overwhelming majority of the population are in need, there the social order departed from the natural purpose of the earth in terms of supporting human life",555. Therefore, H. Kostelnyk took into account the realities of the times and the radical changes in society after the First World War.

With the restoration of Ukraine's independence and the revival of the Greek Catholic Church, a new situation has arisen in our society. After a long stay of the Ukrainian lands in the position of a semicolony in the totalitarian Soviet system, the process of forming a fullfledged Ukrainian macro-society has been launched on a national basis with its own social structure, institutions and independent solution of social problems of the people. However, it proved to be very complicated and painful. After all, "long-term Moscow captivity crippled the Ukrainian people: it destroyed its normal social structure and subordinated the wide masses of Ukraine to the cultural, economic and political influences of Russian society", noted former UNR activist I. Mazepa ${ }^{556}$.

Realization of powerful social potentials of the Ukrainian people, reforms on the way of Ukraine from a totalitarian regime to a legal democratic civil society, to a developed market economy are slowed by the remnants of old institutions and ideas, lack of clear social, political and economic orientations. In the process of revival of the modern Ukrainian statehood, the powerful influence of spiritual aspects, moral factors that form the basis of the Christian religion and are one of the main activities of the Church, are not considered. Meanwhile, in times of the economic crisis, falling living standards of people, during the decline of morality and the indifference of a certain part of society to national-state aspirations more than ever requires the use of ideological and religious factors.

That is why the revived Greek Catholic Church lives the problems of the people, implements its social doctrine in new conditions. "The church has developed its own social teaching, which is nothing more than the codification and adaptation to the questions of the eternal

\footnotetext{
${ }^{555}$ Костельник Г. Границі демократизму. Львів, 1919. С. 63-64.

556 Кононенко К. Україна і Росія. Соціально-економічні підстави української національної ідеї 1917-1960. Мюнхен, 1965. С. 35-56.
} 
principles of law and the Gospel to let people know how to act in all areas, where social life comes into contact - meets morality. And that is why, not for economic or political reasons, the Church has condemned all systems that go against these moral principles," emphasizes Fr. Ivan Shevtsiv ${ }^{557}$.

It should be noted that the current authorities of Ukraine understand that many significant problems during the development of the Ukrainian state cannot be solved without the participation of the Church, which spreads its influence on Ukrainian society. As noted above, the core of the social doctrine of the UGCC is the pursuit of the harmony of individual and public interests, which corresponds to the concept of a restored state. Therefore, the Christian concept of social structure of society on the principles of the spiritual essence of a human being should become a reliable guide to self-improvement of a person and society in the XXI century.

${ }^{557}$ Шевців Іван, о. Збірник. Статті, доповіді і промови. Сідней, 1996. С. 41. 


\section{CONCLUSIONS}

Greek Catholicism, as a social product of the internal development of Ukrainian Christianity, organically synthesized the Eastern and Western Christian traditions and rather prominently displayed Ukrainian national and cultural identity in Central and Eastern Europe. It enabled Western Ukrainians to remain Orthodox for five centuries in faith and traditions, Catholics in love, and God-saved in the hope of ethno-spiritual liberation and unification of the lands. The revival of the Ukrainian Church on national and cultural grounds was not through reformation of Christian doctrine and church separatism, as it was in Germany, England and Russia, but through reconciliation of Eastern and Western Christianity, on the basis of the synthesis of all major church traditions, the assimilation of European social and historical experience.

In the first half of the XIX century, the Greek Catholic Church initiated and most of all contributed to the acceleration of the national identity of Western Ukrainians. Thanks to the clergy, its patriotic agitation from the altar and enlightenment activity in the second half of the century, national "awakening" was achieved in the Western Ukrainian lands.

At the turn of the XIX-XX centuries, the Greek Catholic clergy of Galicia gave way to the secular elite in the national movement. However, this generally had a positive effect on the church structure, as it forced the hierarchs to undertake the strengthening of their own spiritual and organizational foundations, which required purification from both Polish-Latin and Moscophile influences.

The coming of Stanislaviv Bishop Andrey Sheptytsky to the Metropolitan throne in 1901 balanced and even strengthened the role of the clergy.

However, at the turn of the century a new generation of clergymen began to emerge - public figures, who realized the need to fight for the national and political sovereignty of Ukraine, and consequently the separation of the Ukrainian lands from the Polish lands, the introduction of universal right to vote and the equality of the Ukrainian language. It is quite natural that the priesthood was represented in the Galician Sejm and the in the Vienna Parliament. 
Thanks to the personal involvement of Metropolitan Andrey Sheptytsky in the Liberation Competitions of 1914-1923, the Church was able to restore its social authority. As part of the representative revolutionary parliament - the Ukrainian National Council, the Church deputies became the creators of the Western Ukrainian People's Republic.

During the interwar period, the Greek Catholic Church restored the status of an independent moral, spiritual and social force that was closely linked to the national liberation movement - primarily to the centrist UNDO. The documented material confirms that in the interwar period the Greek Catholic Church, including its scientific, educational and publishing structures, its three thousand parishes were centers of national patriotic activity, becoming the spiritual foundation of the national liberation movement in Western Ukraine.

During the Second World War, the policy of the German occupation authorities against the Greek Catholic Church in the Metropolitanate of Galicia and in the part of the Przemysl Eparchy was due to the need for a positive influence on the Western Ukrainian population in order to carry out practical measures for the exploitation of the rich natural resources. The activities of churches in Ukraine were not prohibited. However, the Metropolitan Ordinary Council (not counting individual statements of a tactical character) treated Hitler's occupation, including the mass executions of Ukrainians, Poles and Jews of the region, as a global threat and a threat to the Greek Catholic Church in particular.

The policy of "Sovietization" of the western region of Ukraine in the 1940s caused new ethno-confessional transformations, the collapse of the established religious-church complex. In response to the decision of the Lviv "council" in 1946, the UGCC goes underground and continues pastoral activity in the new conditions.

Until 1988, the official government of the UkrSSR-USSR implemented a policy of forced secularization of the population. The political defeat of the pro-communist forces in the 1990 local elections in the Lviv, Ivano-Frankivsk and Ternopil regions marked the beginning of a period of religious pluralism. On the statewide level, the religious pluralism of society was proclaimed in 1991, the time of independence. However, the sharp departure of the state authorities from the traditional church-religious policy until recent 
time was caused not so much by the democratic principles of its statements as by the real threat of significant social upheaval on the ethno-religious ground.

The current leadership of the church believes that the purpose of the ecumenical movement is to create a Patriarchate of the Ukrainian Church, which should be based on national churches - Orthodox and Greek Catholic. The UGCC, relying on Christian values and moral foundations for centuries, seeks to nurture not only a rich spiritually but also a nationally conscious person by forming a system of ideas and values that can be accepted by society as the basic conditions for its revival. Much attention is paid to the revival of the traditional values of the Ukrainian family, which needs special attention from both the church and the state. In general, the Ukrainian Greek Catholic Church uses all the means available in its arsenal to elevate the national dignity of Ukrainians, to restore historical memory, to assert the spiritual unity and statehood of an independent Ukraine. 


\section{REFERENCES}

\section{Archives}

1. Архів Святоонуфріївського монастиря Отців Василіан (Львів).

2. Архів Служби безпеки України.

3. Архів Управління Служби безпеки України по Львівській області.

4. Государственный архив Российской Федерации.

5. Державний архів Івано-Франківської області.

6. Державний архів Львівської області.

7. Державний архів Тернопільської області.

8. Львівська наукова бібліотека ім. В. Стефаника НАН України. Відділ рукописів.

9. Центральний державний архів вищих органів влади та управління України.

10. Центральний державний архів громадських об'єднань України.

11. Центральний державний історичний архів України у м. Львові.

12. Діло 1926

\section{Materials of periodicals}

13. Діло 1930

14. Діло 1931

15. Діло 1932

16. Діло 1933

17. Діло 1939

18. Зоря Галицька 1848

19. Комуністична освіта 1940

20. Краківські вісті 1942

21. Краківські вісті 1943

22. Львівські архієпархіальні відомості 1925

23. Львівські архієпархіальні відомості 1932

24. Львівські архієпархіальні відомості 1942

25. Львівські архієпархіальні відомості 1943

26. Львівські архієпархіальні відомості 1944

27. Місіонар 1918 
28. Мiciонар 1920

29. Місіонар 1926

30. Місіонар 1937

31. Нова Зоря 1926

32. Нова Зоря 1927

33. Нова Зоря 1932

34. Нова Зоря 1936

35. Рідна земля 1943

36. Руслан 1910

37. Русские ведомости 1916

38. Талергофський альманах 1935

\section{Monographs, brochures, articles}

39. Авакумов Ю. Митрополит Андрей (Шептицький) i проблеми церковної єдності в Росії. Ковчег. Ч. 3. Львів, 2003. С. 101-114.

40. Ададуров В. Львів у наполеонівську епоху. Львів: місто - суспільство - культура : Збірник наук. праць / За ред. М. Мудрого. Львів: ЛДУ ім. І. Франка, 1999. С. 202-224.

41. Александрович В. Мистецтво Галицько-Волинської держави. Львів: Інститут українознавства ім. І. Крип'якевича НАН України, 1999. 132 с.

42. Андрієнко О. 3 історії Української церкви. Київська старовина. 1992. № 1. С. 124-137.

43. Андрій Палій - будівничий та керманич «Маслосоюзу». Статті, спогади, листи. / Упор. Р. Матейко. Тернопіль: Економічна думка, 2001. 294 с.

44. Андрухів I. Галицька Голгофа. Ліквідація УГКЦ на Станіславщині в 1945-1961 pp. Івано-Франківськ, 1997. 84 с.

45. Андрушків Б. Зарваниця - святиня землі української. Тернопіль: Підручники і посібники, 2001. 192 с.

46. Антонюк Н. В. Українське культурне життя в «Генеральній губернії» (1939-1944 рр.). Львів, 1997. 232 с.

47. Апостольський лист Папи Лева XIII «Про реформу Чину св. Василія Великого Української нації в Галичині». Записки ЧСВВ. С. 2. Т. 11. Рим, 1982. С. 351.

48. Аркуша О. Галицький сейм: виборчі кампанії 1889 і 1895 рр. Львів, 1996. 174 с. 
49. Аркуша О., Мудрий М. Русофільство в Галичині в середині XIX - на початку XX ст.: генеза, етапи розвитку, світогляд. Вісник Львівського університету. Серія історична. Вип. 34. Львів, 1999. С. 231-268.

50. Арсенич П. Греко-католицькі священики в національних змаганнях українців Галичини. Нова зоря. 1991. Квітень. Ч. 5-6.

51. Арсенич П. Йосиф Сліпий та його соратники репресовані священики. Кардинал Йосиф Сліпий $і$ сучасність. C. $126-127$.

52. Байса Г. Монахи Студитського уставу. Постуn. 2000. 22 січня.

53. Бандрівський М. Митрополит Андрей Шептицький меценат української археології. Берестейська унія (1596-1996). Львів, 1996. С. 204-207.

54. Бандрівський М. Археологічна діяльність Ісидора Шараневича (1829-1901). Постаті української археології: Матеріали і дослідження з археологї Прикарпаття $і$ Волині. Вип. 7. Львів, 2000. С. 95-97.

55. Бандрівський М., Лукомський Ю., Сулик Р. 3 історії досліджень Успенського собору в Галичі. Записки НТШ. Т. CCXXV. Львів, 1993. С. 393-405.

56. Бандрівський М. Пам'яткоохоронна діяльність Церкви в контексті національно-культурного руху в Галичині (кінець $\mathrm{XIX}$ - XX ст.). Автореферат дис. на здобуття наук, ступеня канд. іст. наук. Львів, 2001. 20 с.

57. Баран В. Україна: новітня історія (1945-1991 рр.). Львів, 2003.670 с.

58. Бедрій А. Український націоналізм i християнство. Визвольний илях. 1962. № 1. С. 41-43.

59. Бендас Д. Священики мученики, сповідники вірності. Ужгород, 1999. $412 \mathrm{c}$

60. Бердяев М. Судьба России. Опыты по психологии войны и национальности. Москва: Философское общество СССР, 1990. $240 \mathrm{c}$.

61. Береславський М.3. 3 історії Української грекокатолицької церкви. Львів, 1992. 80 с.

62. Біднов В. Дослідження церковної історії в православних країнах. Крем'янець, 1931. 20 с. 
63. Білавич Г., Савчук Б. Товариство «Рідна школа» (18811939). Івано-Франківськ: Лілея-НВ, 1999. 208 с.

64. Білас Я. І. Митрополит Андрей Шептицький і проблеми національно-визвольного руху українців. Автореферат дис. на здобуття наук. ступ. канд. іст. наук. Київ, 2003. 23 с.

65. Білас I. Репресивно-каральна система в Україні 19171953. Кн. 1. Київ: Либідь - Військо України, 1994.686 с.

66. Білий Б. Митра Перемиських владик або так звана «Корона Данила»: міфи і факти. Перемишль і Перемиська земля протягом віків / За ред. С. Заброварного; упор. С. Заброварний, М. Литвин, Ф. Стеблій. Перемишль; Львів, 2003. С. 245-248.

67. Бойко М. Владика Діонісій Няраді. Католицький щзорічник. Київ, 1996. С. 107-110.

68. Бойко I. Владика Миколай Чарнецький: ісповідник, мученик, чудотворець. Львів, 1997. 92 с.

69. Боляновський А. Дивізія «Галичина». Історія. Львів, 2000. 528 c.

70. Бондаренко В. Українська держава: співпраця на новому етапі. Людина і світ. 1998. № 7. С. 26-32.

71. Бочковський О. Вступ до націології. Генеза. 1996. № 1 (4). С. 81-107.

72. Боцюрків Б. Українська Греко-католицька церква в катакомбах (1946-1989). Календар «Благовіста». 1998. Гурово Іловецьке, 1998. С. 93-118.

73. Ваврик М., ЧСВВ. Нарис розвитку i стану Василіанського Чина. XVII - XX ст. Рим, 1979. 219 с.

74. Васьків А. Бібліотека і архів Митрополичого ординаріату Греко-католицької церкви після Першої світової війни. Республіканещьь. 1994. № 5-9. С. 85-88.

75. Васьків Р. Блаженний Єпископ-Новомученик Кир Григорій Лакота як ректор першої повної духовної семінарії в Перемишлі та його праця в інших інституціях. Перемишль $i$ Перемиська земля протягом віків. / За ред. С. Заброварного; упор. С. Заброварний, М. Литвин, Ф. Стеблій. Перемишль; Львів, 2003. С. $155-156$.

76. Васьковський В. «Горячі точки»: стан справ i шляхи врегулювання. Людина і світ. 1990. № 10. С. 31. 
77. Вацеба О. Нариси 3 історії західноукраїнського спортивного руху. Івано-Франківськ, 1997. 232 с.

78. Ведуть в Зарваницю стежки i дороги / упоряд. Д. Михайлюк. Тернопіль; Теребовля: Збруч, 1995. 24 с.

79. Великий А. Г., ЧСВВ. Світло і тіні української історії. Причинки до історії української церковної думки. Рим: вид. оо. Василіян: 1969. 219 с.

80. Великий А. Г., ЧСВВ. 3 літопису християнської України: Церковно-історичні радіолекції з Ватикану. Т. VIII: XIX ст. Рим: Вид-во оо. Василіян, 1976. 275 с.

81. Верига В. Нариси історії України (кінець XVIII - початок ХХ ст.). Львів: Світ, 1996. 447 с.

82. Вл. Любомир (Гузар). Екуменічна місія Східних Католицьких Церков у баченні митрополита Андрея (Шептицького). Ковчег. Ч. 2. Львів, 2000. С. 189-212.

83. Вивезене росіянами українське духовенство. Нива. Львів, 1916. Цвітень. Ч. 4. С. 262-264.

84. Винниченко I. Україна 1920-1980-х рр.: депортації, заслання, вислання. Київ, 1994. 126 с.

85. «Вірю, що усі з’єднаємося у Христі»: Інтерв’ю 3 Ординарієм Івано-Франківським Владикою Софроном Дмитерком ЧСВВ з нагоди його 80-літнього ювілею. Нова зоря. 1997. 27 травня.

86. Волинець О.О. Функціонування Української грекокатолицької церкви в контексті державно-церковних відносин. Автореферат дис. на здобуття наук. ступ. канд. іст. наук. Київ, 2003. $20 \mathrm{c}$.

87. Володимир Винниченко та ідея українського патріархату. Нова Зоря. 1993. Жовтень. Ч. 35-36.

88. Гайова О. Митрополит Галицький. Украӥнський альманах 2001. Варшава, 2001. С. 99-103.

89. Гайковський М. Велике протистояння: опір грекокатолицької церкви більшовицькому окупаційному режимові (вересень 1939 - червень 1941). Київська церква. 1999. № 5. С. 25-30.

90. Гайковський М. Сучасне і майбутнє України: думки і візії митрополита Андрея Шептицького. Київська изерква. 2000. № 1. C. 43-46. 
91. Гайковський М. І.Хресною дорогою: Функціонування i спроби ліквідації Української Греко-Католицької Церкви в умовах СРСР у 1939-1941 та 1944-1946 роках: збірник документів i матеріалів / упор. Гайковський М. І. Львів: Місіонер, 2006. $650 \mathrm{c}$.

92. Галицькі митрополити. Біографічний довідник. Львів: Логос, 1992.94 с.

93. Геллер Е. Нація-етнос. Мала енииклопедія етнодержавознавства. Київ: Генеза; Довіра, 1996. С. 124.

94. Гель I. Духовність України і спільний європейський дім. Украӥна. Наука $і$ культура. Вип. 26-27. Київ: Знання, 1993. C. 132-137.

95. Геник Л.Я. Релігійно-моральне виховання молоді в навчальних закладах Східної Галичини кінця XIX - початку XX ст. Івано-Франківськ: Плай, 2000. 272 с.

96. Герасимович I., Терлецький О. Шкільництво в Галичині в другій пол. XIX і на поч. XX ст. Енциклопедія українознавства. Загальна частина. Т. 3. Мюнхен ; Нью-Йорк, 1949. С. 928-931.

97. Герич Ю. Як відбувався «возсоєдинительний собор»у Львові 8 березня 1946 р. Календар «Світла». Торонто; НьюЙорк, 1995. С. 88-91.

98. Глистюк Я. Два листи о. Мирослава Івана Любачівського до митрополита Андрея (Шептицького) 3 1941-1942 років. Ковчег. Ч. 3. Львів, 2001. С. 507-510.

99. Гнот С. I. Греко-католицька церква i організація суспільної опіки Галичини (1921-1939 рр.). Актуальні проблеми державного управління. Вип. 6. Львів, 2001. С. 299-309.

100. Головащенко С. Історія християнства. Курс лекцій. Київ: Либідь, 1999. 352 с.

101. Головна Руська Рада. 1848-1851. Протоколи засідань i книга кореспонденції / За ред. О. Турія. Львів, 2002.

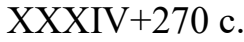

102. Гордієнко В. Сталінізм і Українська греко-католицька церква. Матеріали наук. конферениії. Львів, 1990. С. 41-51.

103. Грабовецький В. Ілюстрована історія Прикарпаття. Вид. 2. Т. 3. Івано-Франківськ: Нова Зоря. 464 с. 
104. Грабовецький В. Сторінки літопису Івано-Франківського Катедрального Собору Святого Воскресіння. Івано-Франківськ: Нова Зоря, 1999. 80 с.

105. Грабовецький В. Андрей Шептицький і Станіславівщина. Галичина. 1994. 21 жовтня.

106. Грицак Я. Нарис історії України. Формування модерної української нації XIX -XX століття. Київ, 1996. 360 с.

107. Грушевський М. Історія України-Руси. Т. V. Київ: Наукова думка, 1994. 704 с.

108. Грушевський М. Історія України-Руси. Т. III. Київ: Наукова думка, 1993. 592 с.

109. Грушевський М. Ілюстрована історія України. Нью-Йорк, $1990.578 \mathrm{c}$.

110. Грушевський М. Спомини. Київ. 1989. № 9. С. 108-149.

111. Грушевський М. 3 історії релігійної думки на Україні / Ред. П. К. Вовк. Київ: Освіта, 1992. 192 с.

112. Гудзяк Б. Криза i реформа: Київська митрополія, Царгородський патріархат і генеза Берестейської унії. Львів: Інститут історії церкви ЛБА, 2000. 426 с.

113. Гузар Л. У пошуках гармонії. Історичний контекст укладення Берестеської унії $i$ перше поунійне покоління: матеріали Перших «Берестейських читань». Львів, ІваноФранківськ, Київ, 1-6 жовтня 1994 р. / ред. Б. Гудзяк. Львів: Інститут Історії церкви Львівської Богословської Академії, 1995. C. 1-6.

114. Гуркіна С. Митрополит Андрей (Шептицький) в період німецької окупації Галичини: найновіша історіографія питання (1989-2000 роки). Ковчег. С. 556-565.

115. Делятинський Р. І. Становище та діяльність духовенства станіславівської єпархії УГКЦ в 1919-1920 pp. Вісник Прикарпатського університету. Історія. Вип. VII. ІваноФранківськ, 2003. С. 69-77.

116. Демкович-Добрянський М. Українсько-польські стосунки у XIX сторіччі. Мюнхен, 1969. 144 с.

117. Депортації: Західні землі України кінця 30-х - початку 50-х рр. Документи, матеріали, спогади / Відп. ред. Ю. Сливка. Т. 1-3. Львів: НАН України, Інститут українознавства ім. І. Крип'якевича, 1996-2002. Т. 1. 751 с. Т. 2.537 с. Т. 3. 418 с. 
118. Депортації українців та поляків: кінець 1939 - початок 50-х років. Львів, 1998. 132 с.

119. Дзьобан О. Бібліотека митрополита Андрея Шептицького у Львові. Записки Львівської наукової бібліотеки ім. В. Стефаника. Львів, 2002. Вип. 9/10. С. 141-151.

120. Дзьобан О., Тимочко М. Парафіяльні школи та підручники, видані в Перемишлі українською мовою (кінець XVIII - перша половина XIX ст.). Перемишль і Перемиська земля протягом віків / За ред. С. Заброварного; упор. С. Заброварний, М. Литвин, Ф. Стеблій. Перемишль; Львів, 2003. С. 260-272.

121. Дідула П. Щоб не зрадити ідеї патріархату. Патріархат. 2002. № 3. С. 12-13.

122. Діяння Собору УГКЦ 8-10 березня 1946 р. Львів, 1946. $167 \mathrm{c}$.

123. Добромильська реформа і відродження Української церкви: доповіді та матеріали конференції. Львів: Місіонер, 2003. 304 c.

124. Додаток до Чинностей і Рішень руского провінціяльного Собору в Галичині, отбувшегося во Львові в р. 1891. Львів, 1897. C. 97-199.

125. Документи свідчать. Вид. друге, доп. / Упор. А. Гайдаш. Ужгород, 1985. $160 \mathrm{c.}$

126. Дорошенко Д. Арест и ссылка митрополита А. Шептицкого. На чужсой стороне. Прага, 1925. Вып. XII. C. 160-166.

127. Драгоманов M. Чудацькі думки про українську національну справу. Літературно-публіцистичні праці; у 2-х томах. Т. 1. Київ, 1970. 531 с.

128. Дрогомирецька Л. Греко-католицьке духовенство Галичини в українському кооперативному русі (1920-1939 рр.). Вісник Прикарпатського університету. Вип. VII. Історія. C. 77-89.

129. Дутчак П. Клерикально-філантропічні товариства в Західній Україні (20-30-ті рр. ХХ ст.). Питання історії України. Т. 6. Чернівці, 2003. С. 154-157.

130. Дух i ревність. Владика Снігурський та інші перемишляни / Упор. В. Пилипович. Перемишль; Львів, 2002. 498 c. 
131. Сгрешій О. Єпископ Григорій Хомишин і питання українсько-польського порозуміння 1904-1939 pp. ІваноФранківськ: Плай, 2001. 71 с.

132. Єгрешій О. Взаємовідносини митрополита Андрея Шептицького i єпископа Григорія Хомишина. Галичина. Всеукрайнський науковий $i$ культурно-просвітницький краєзнавчий часопис. 2001. № 5-6. С. 315-321.

133. Сгрешій О. Григорій Хомишин i український націоналізм. Питання історії Украӥни: Зб. наук, статей. Чернівці, 2002. T. 5. C. 101-104.

134. Сгрешій О. Суспільно-політична та культурнопросвітницька діяльність єпископа Григорія Хомишина (19041945 рр.) Автореферат дис. на здобуття наук, ступеня канд. іст. наук. Івано-Франківськ, 2003. 20 с.

135. Жуковський А., Субтельний О. Нарис історії України. Львів, 1992. 230 с.

136. Заброварний Б. Депортації українського населення із Закарпаття в 1944-1947 роках. Історіографічні дослідження в Україні / Голова редкол. В. Смолій; відп. ред. Ю. Пінчук. Вип. 13. У 2-х ч.; Україна - Польща: історія і сучасність. Збірник наук, праць і спогадів пам'яті П.М. Калиниченка (1923-1983). Ч. 1. Київ, 2003. С. 359-374.

137. Заборовський Я. Ю. Митрополит Андрей Шептицький: Нарис про життя і служіння Церкві та народові (1865 - 1944 рр.). Івано-Франківськ, 1995. 64 с.

138. Завірач Василь, о. Флорентійський Вселенський Собор і Берестейська унія. Берестейська Унія (1596-1996). С. 65.

139. Загайкевич М. Михайло Вербицький: сторінки життя i творчості. Львів, 1998. 148 с.

140. Заїкін В. 3 сучасної української церковної історіографії. Записки ЧСВВ. Львів, 1927. Т. 2. Вип. 1-2. С. 425-431.

141. Заїкіни А. і В. Матеріали до бібліографії української історії 1930-1931. Записки ЧСВВ. Львів; Жовква, 1936. Т. 6. Вип. 1-2. С. 338-394.

142. Зайцев О., Зайцев Ю. На шляху до незалежності. Історія Украӥни. Вид. 2-ге. Львів: Світ, 1998. 488 с.

143. Закон України «Про свободу совісті та релігійні організації». Відомості Ради УРСР. 1991. № 25. С. 656-666. 
144. Західна Україна під большевиками. IX. 1939 - VI. 1941 / Збірник під редакцією М. Рудницької. Нью-Йорк, 1958. 494 с.

145. Західно-Українська Народна Республіка 1918-1923. Док. i мат. У 5-ти томах / Відп. ред. О. Карпенко. Івано-Франківськ, 2001. T. $1.584 \mathrm{c}$.

146. Західно-Українська Народна Республіка 1918-1923. Док. i мат. У 5-ти томах / Відп. ред. О. Карпенко. Івано-Франківськ, 2001. Т. 2. 712 c.

147.Здіорук С. Національна церква у контексті державотворення в Україні. Розбудова держави. 1994. № 1. С. 51-56.

148. Злупко С. Вплив Енцикліки «Нові справи» на становлення і розвиток християнсько-демократичної економічної думки в Україні. Церква і соціальні проблеми. Енцикліка «Сотий рік». Львів, 1993. С. 46-51.

149. Злупко С. На чатах рідної землі: Свген Храпливий учений, організатор, патріот. Львів: ЛНУ ім. І. Франка, 1999. $283 \mathrm{c}$.

150. Жовківщина. Історичний нарис. Т. 1 / відп. ред. Микола Литвин; Інститут Українознавства ім. І. Крип'якевича. Жовква ; Львів ; Балтимор, 1994. 325 с.

151. Жовківщина: Історико-мемуарний збірник. Т. 2 / відп. ред. Микола Литвин; Інститут українознавства ім. I. Крип'якевича. Жовква ; Львів ; Балтимор, 1995. 349 с.

152. Жовківщина: Історико-мемуарний збірник. Т. 3 / відп. ред. Микола Литвин; Інститут українознавства ім. I. Крип’якевича. Жовква ; Львів ; Балтимор, 1995. 328 с.

153. Іван Крип'якевич у родинній традиції, науці, суспільстві. Львів, 2001. 960 с.

154. Іерархи Української Греко-Католицької Церкви в Україні. Поступ. 1999. 11 вересня.

155. Інститут історії Церкви Львівської богословської академії. Львів, 2000. 20 с.

156. Ісаєвич Я. Українське книговидання: витоки, розвиток, проблеми. Львів: Інститут українознавства ім. І. Крип'якевича НАН України, 2002. 520 с.

157. Ісаєвич Я. Галицько-Волинська держава. Львів, 1999. $36 \mathrm{c}$. 
158. Ісаєвич Я. Львівське успенське братство, його школа $\mathrm{i}$ друкарня. Львів: історичні нариси. Львів, 1996. С. 82-89.

159. Ісаєвич Я. Братства та їх роль в розвитку української культури XVI - XVIII ст. Київ: Наукова думка, 1966. 248 с.

160. Ісаїв П. Історія церкви. Енциклопедія українознавства. Загальна частина. Т. 2. Київ, 1995. С. 611-623.

161. Ісіченко I., архиєп. Історія Христової церкви в Україні. Харків, 1999. 264 с.

162. Ісіченко І. Виступ на науковій конференції. Визвольний илях. 1995. № 11. С. 1301-1302.

163. Історія релігії в Україні / ред. А. Колодний [та ін.]. Т. 4. Католицизм. Київ, 2001. 598 с.

164. Історія релігії в Україні / За ред. А.М. Колодного і П.Л. Яроцького. Київ: Знання, 1999. 735 с.

165. Історія релігії в Україні. Т. 4. Католицизм. 598 с.

166. Історія споживчої кооперації України / Кер. авт. колективу С. Гелей. Львів, 1996. 384 с.

167. Історія України / Заг. ред. В. Смолія. 3-є вид. Київ, 2002. $472 \mathrm{c}$.

168. Історія України / Крівник авт. колективу Ю. Зайцев. Львів: Світ, 1996. 488 с.

169. Історія України. Вид. 2-е. Львів, 1998. 352 с.

170. Історія Церкви на Україні (від найдавніших часів до монгольської навали). Жовква: Місіонер, 1932. 182 с.

171. Казимира Б. Митрополит Андрей Шептицький та канадські українці. Пропам'ятна книга оо. Василіян у Канаді. Торонто, 1953. С. 97-149.

172. Калинович I. Бібліографія українознавства за 19141923 рр. Вип. 1: Історія України. Львів, 1924. 59 с.

173. Кальницький М., Малаков Д., Юркова О. Нариси з історії Києва. Київ: Генеза, 2002. 384 с.

174. Канчалаба О. Релігійно-церковна періодика XIX - першої половини ХХ ст. у фондах ЛНБ ім. В. Стефаника НАН України. Українська періодика: історія і сучасність. Вип. 6. Львів, 2000. C. 189-193.

175. Карачко С. Українська Греко-Католицька Церква на Буковині. Католицький щзорічник. 1996. Київ, 1996. С. 78-80. 
176. Кардинал Йосип Сліпий і сучасність. Збірник матеріалів конференції. Івано-Франківськ, 2002. 216 с.

177. Каховський I. За тверезість. Короткий історичний огляд Українського протиалкогольного й протинікотинового руху. Львів, 1934. 48 с.

178. Київська Русь: культура, традиції: зб. наук. праць / Відп. ред. Я. Ісаєвич. Київ: Наукова думка, 1982. 151 с.

179. Киричук О.С. Ставропігійський інститут у громадському житті Галичини (друга пол. XIX - поч. XX ст.). Львів, 2001. 19 с.

180. Киричук Ю. Нариси з історії українського національновизвольного руху 40-50-х рр. ХХ століття. Львів, 2000. 304 с.

181. Кияк Р. Капелянська служба у Збройних силах України. Нова зоря. 1996. Ч. 21.

182. Кияновська Л. Пам'яті митрополита Андрея Шептицького. Київська Церква. 1999. № 6. С. 133-134.

183. Кіндрат К., Кіндрат К. Андрей Шептицький - праведник України. Християнські иінності: історія $і$ погляду трете тисячоліття. 3б. наук. записок Національного університету «Острозька академія». T. VI. Острог, 2002. С. 26-31.

184. Кметь В. Львівська православна єпархія: короткий огляд історії. Шематизм Львівсько-Сокальської єпархї Української Православної Церкви Київського Патріархату. 2000 рік. Статистично-біографічний довідник. Львів, 2000. С. 8-22.

185. Кобута С. Політичні аспекти легалізації Української Греко-Католицької Церкви (1987-1991). Людина $i$ політика. 1999. № 3. C. 23-28.

186. Ковалюк В. Культурологічні та духовні аспекти «радянізації» Західної України (вересень 1939 - червень 1941). Украӥнський історичний журнал. 1993. № 2. С. 3-17.

187. Коваль I. Ярослав Пастернак - основоположник української церковної археології. Нова зоря. 1999. 26 травня.

188. Козак М. Пом'яни, Господи, душі слуг твоїх. Перемишль; Львів, 2002.280 с.

189. Колодний А. Андрей Шептицький про будівництво рідної хати. Християнство і національна ідея : науковий збірник. Київ; Тернопіль; Краків: Укрмедкнига, 1999. С. 17-23. 
190. Комар Ю. [Рецензія на книгу В. Пащенка «Православ'я в новітній історії України» (Полтава, 2001)]. Ковчег. Ч. 3. Львів, 2001. C. 549-552.

191. Комар Ю., Турій О. [Рецензія на книгу В. Пащенка «Греко-католики в Україні: від 40-х років XX століття до наших днів» (Полтава, 2002)]. Ковчег. Ч. 2. Львів, 2003. С. 322-329.

192. Кондратюк К. К. Українська історіографія XIX - початку XX століть: основні напрями і концепції. Львів, 2002. 240 с.

193. Кононенко К. Україна і Росія. Соціально-економічні підстави української національної ідеї 1917-1960. Мюнхен, 1965. $529 \mathrm{c}$.

194. Королько А. Культурно-просвітницька і громадськополітична діяльність о. Івана Озаркевича (1826-1903) в контексті українського національного відродження. Питання історії України. Чернівці: Технодрук, 2013. Т. 16. С. 37-44.

195. Костельник Г. Нова доба нашої Церкви. Львів, 1926. 16 с.

196. Костельник Г. Вибрані твори. Київ, 1987. 264 с.

197. Костельник Г. Границі демократизму. Львів, 1919. 221 с.

198. Костельник Г. Ultra posse. Вибрані твори / упоряд. та передм. О. Гірняк. Ужгород: Гражда, 2008. 400 с.

199. Кравченюк О. Велетень зо Святоюрської гори. Торонто, 1963. $156 \mathrm{c}$.

200. Кравчук А. Християнська етика підчас німецької окупації Галичини, 1941-1944: митрополит Андрей (Шептицький) про солідарність, опір владі та захист святості життя. Ковчег. C. 224-272.

201. Кравчук А. Християнська соціальна етика під час німецької окупації Галичини, 1941-1944: Митрополит Андрей (Шептицький) про солідарність, опір владі та захист святості життя. Ковчег. Львів, 2000. Ч. 2. С. 224-269.

202. Красівський О. За українську державу і церкву. Львів: Інститут українознавства ім. І. Крип'якевича НАНУ, 1995. 84 с.

203. Кревецький I. Видавництво Чину св. Василія Великого в Жовкві. Альманах Василіянських богословів. Кристинопіль, 1933. C. 35-39.

204. Кревецький I. Українська католицька преса. Нова зоря. 1928. Ч. 101. 30 грудня. 
205. Кривава книга / Упорядник, автор передмови Я. РадевичВинницький. Передрук вид. 1919, 1921 pp. Дрогобич: Відродження, 1994. 274 с.

206. Крив'як Б. Видавничо-просвітницька діяльність Василіянського Чину в Україні. Київська иерква. 1999. Ч. 6. С. 36-37.

207. Крип'якевич I. Галицько-Волинське князівство. Львів, $1999.220 \mathrm{c}$.

208. Крутій-Вігоринський I. Видавництво оо. Василіян у Жовкві. Календар «Місіонаря». Жовква, 1932. С. 67-72.

209. Кубійович В. Українці в Генеральній Губернії. 1939-1941. Історія Українського Центрального Комітету. Чикаго, 1975. $664 \mathrm{c}$.

210. Кугутяк М. Історія української націонал-демократії. 1918-1929. Т. 1. Київ ; Івано-Франківськ, 2002. 534 с.

211. Кугутяк М. Історія української націонал-демократії. 1918-1929. Т. 2. Київ ; Івано-Франківськ, 2004. 704 с.

212. Кугутяк М. Галичина: сторінки історії. Нарис суспільнополітичного руху (ХІХ ст. - 1939 р.). Івано-Франківськ, 1993. 202 c.

213. Кугутяк М. Пам'яті жертв трагічних подій у Перемишлі і Синевідську восени 1914 року. Галичина. Науковий $і$ культурнопросвітницький краєзнавчий часопис. 2003. № 9. С. 134-144.

214. Культурне життя в Україні: західні землі. Документи i матеріали. Т. 1-3. Львів: НАН України, Інститут українознавства ім. І. Крип`якевича, 1995, 1998, 2006. Т. 1. 748 с. Т. 2. 537 с. Т. 3. $856 \mathrm{c}$.

215. Кульчицький С. Нi, то не був подарунок долі. Високий Замок. 1999. 18 серпня.

216. Лебедович I. Полеві духовники Української Галицької Арміі. Вінніпег, 1963. 325 с.

217. Липинський В. Релігія і церква в історії України. Київ: Рада, 1995. 96 с.

218. Лисенко О. Церковне життя в Україні 1943-1946 рр. К.: Інститут історії України НАНУ, 1998. 404 с.

219. Лисяк-Рудницький I. Нариси 3 історії нової України. Львів: Меморіал, 1991. 101 с.

220. Литвин В. Україна: доба війн і революцій (1914-1920). Київ, 2003. 488 с. 
221. Литвин М. Українсько-польська війна 1918-1919 pp. Львів: Інститут українознавства НАН України, Інститут Центрально-Східної Європи, 1998. 488 с.

222. Литвин М., Луцький О., Науменко К. 1939. Західні землі України. Львів, 1999. 152 с.

223. Литвин М., Науменко К. Історія галицького стрілецтва. Львів, 1990. 200 с.

224. Литвин М., Науменко К. Історія ЗУНР. Львів: Інститут українознавства ім. І. Крип'якевича НАНУ, 1995. 368 с.

225. Ліквідація УГКЦ (1939-1946): документи радянських органів державної безпеки. Київ: ПП Сергійчук М.I., 2006. Т. 2. $919 \mathrm{c}$.

226. Лірвак з-над Сяну: Перемиські друки середини XIX століття / Упор. В. Пилипович. Перемишль, 2001. 451 с.

227. Літопис нескореної України. Т. 1-2. Львів, 1993, 1995. T. 1.800 c. T. 2.752 c.

228. Лозинський М. Видавнича діяльність Василіянського Чину в умовах Добромильської реформи і в сучасний період. Добромильська реформа $і$ відродження Української черкви. Львів: Місіонер, 2003. С. 146-151.

229. Лотоцький О. Сторінки минулого. Т. 3. Варшава, 1934. $392 \mathrm{c}$.

230. Лукань Р. Список книжок Видавництва ЧСВВ в Жовкві. Записки ЧСВВ. Рим, 1967. Т. V. С. 389-420.

231. Лужницький Г. Українська церква між Сходом і Заходом: нарис історії Української Церкви. Філадельфія: Провидіння, 1954. $723 \mathrm{c}$.

232. Львівська богословська академія. Львів, 2000. 90 с.

233. Магочі П. Пряшівська греко-католицька єпархія: русинська чи словацька церква? Ковчег. Ч. IV. Львів, 2003. C. 170-173.

234. Мазур О., Патер І. Львів у роки Першої світової війни. Львів. Історичні нариси. Львів, 1996. 648 с.

235. Мазур М., Скробач В. Кооперативний буквар. ІваноФранківськ, 1995. С. 65-67.

236. Макарчук С. А. Этносоциальное развитие и национальные отношения на западноукраинских землях в период империализма. Львов: Вища школа, 1983. 255 с. 
237. Малик Я., Сурмач О. Преса про діяльність Української греко-католицької церкви в період німецької окупації. Украӥнська періодика: історія $і$ сучасність. Львів, 1999. C. 169-173.

238. Мартинюк М. Українські періодичні видання Західної України, країн Центральної та Західної Свропи (1914-1939рр.): Матеріали бібліографії. Львів: НАН України, Львів. наук. б-ка ім. В. Стефаника, 1998. 297 с.

239. Мартирологія Української Церкви / Упор. О. Зінкевич, Т. Лончина. Торонто; Балтимор, 1985. 839 с.

240. Мартирологія українських церков. Т. II: Українська Греко-католицька церква. Торонто; Балтимор, 1987.1207 с.

241. Марунчак М. Митрополит Андрей Шептицький на Заході 1920-1923. Вінніпег; Едмонтон, 1981. 43 с.

242. Марчук B. Українська Греко-Католицька Церква. Історичний нарис. Івано-Франківськ: Плай, 2001. 164 с.

243. Марчук В. Церковно-релігійне життя в Західноукраїнській Народній республіці (1918-1919 рр.). Iсторіографічні дослідження в Украӥні. / Голова редкол. В. Смолій; відп. ред. Ю. Пінчук. Вип. 13. У 2-х ч.; Україна - Польща: історія $\mathrm{i}$ сучасність. Збірник наук, праць і спогадів пам'яті П.М. Калиниченка (1923-1983). Ч. 1. Київ, 2003. С. 215-220.

244. Марчук В. Греко-католики в другій Речі Посполитій: суспільний чин та конфесійно-територіальний устрій. Галичина: Всеукрайнський науковий $i$ культурно-просвітній краєзнавчий часопис. Івано-Франківськ, 2001. Ч. 5-6. С. 302-307.

245. Медвідь Ф., Коваленко А. Дослідження ролі релігії у національному самовизначенні держави. Київська Церква. 2000. № 1. C. 130-134.

246. Меморандум митр. А. ІІептицького «Про церковну організацію». Церква $i$ церковна єдність. Документи $i$ матеріали. Т. 1. Львів: Свічадо, 1995. С. 130-131.

247. Митрополит Андрей Шептицький. Матеріали i документи (1865-1944 рр.). Друге доп. вид. / За ред. Я. Заборовського. Львів; Івано-Франківськ, 1995. 64 с.

248. Митрополит Андрей Шептицький: життя i діяльність. Документи i матеріали 1899-1944 / Упоряд. О. Гайова, А. Кравчук. Т. 1. Церква і церковна єдність; Т. 2. Кн. 1 Церква 1 
суспільне питання. Пастирське вчення та діяльність. Т. 2. Кн. 2. Церква і суспільне питання. Листування. Львів, 1995-1998. Т. 1. 521 с. Т. 2 , кн. 1.572 с. Т. 2., кн. 2.571 с.

249. Мельничук П. 3 історії «Нової зорі». Нова зоря. 1991. Червень. Ч. 11-12.

250. Москалюк М. Українська католицька народна партія i проблема польсько-українського порозуміння. Українськопольські відносини в Галичині у XX cm. Івано-Франківськ, 1997. C. 221-224.

251. Москалюк М. Український християнсько-суспільний рух Галичини в 20-х рр. XX ст. Автореферат дис. на здобуття наук. ступ. канд. політ. наук. Київ, 1998. 19 с.

252. Москвофільство: документи і матеріали / Вступна стаття, коментарі і матеріали О. Сухого; заг. ред. С. Макарчука. Львів, 2001. $236 \mathrm{c}$.

253. Мудрий Софрон, о. Нарис історії церкви в Україні. Рим; Львів: Вид-во оо. Василіян, 1995. 404 с.

254. Музичка I., о. Вступне слово до збірника. Церква $i$ сочіальні проблеми. Енцикліка «Сотий рік». Львів, 1993. С. 3-15.

255. Нагаєвський I. Історія Української держави XX ст. Київ, 1993. $413 \mathrm{c}$.

256. Нагаєвський I., о. Католицька церква в минулому i сучасному України. Філадельфія, 1950. 88 с.

257. Назарко І. Київські і галицькі митрополити. Торонто: Вид-во ОО. Василіян, 1962. 271 с.

258. Нариси історії архівної справи в Україні / За заг. ред. I. Матяш, К. Климової. Київ: Видавничий дім «КМ Академія», 2002. 612 c.

259. Нариси з історії суспільних рухів та політичних партій в Україні (XIX - XX ст.) / за заг. ред. Я.Й. Малика. Львів: Світ, 2001. 294 c.

260. Огієнко I. Українська Церква: Нариси 3 історії Української православної церкви. Прага, 1942. 222 с. (2-евид.: Київ: Абрис, 1993. 284 с.).

261. Оглоблин О. Українська церковна історіографія. Украӥнський історик. 1969. № 1-4 (57-60). С. 12-29.

262. Одинцов М.И. Путь длиною в семь десятилетий от конфронтации к сотрудничеству: государственно-церковные 
отношения в истории советского общества. На пути к свободе совести. Москва, 1989. С. 29-71.

263. Онишкевич Ігор Ілля «Ми молимося за єдність українських християн...». Нова зоря. 1993. Вересень. Ч. 35-36.

264. Орлевич І.В. Діяльність Львівського Ставропігійського інституту (кінець XVIII - 60-і pp. XIX ст.). Автореф. дис. на здобуття наук. ступ, канд. іст. наук. Львів, 2000. 20 с.

265. Павлище П. 3 історії Перемиської капітули. Перемишль $i$ Перемиська земля протягом віків / За ред. С. Заброварного; упор. С. Заброварний, М. Литвин, Ф. Стеблій. Перемишль; Львів, 2003. C. 167-187.

266. Павлишин О. Організація цивільної влади ЗУНР у повітах Галичини (листопад-грудень 1918 року). Україна модерна. Львів, 1999. Число 2-3. С. 132-193.

267. Павлишин О. Соціально-політичний портрет українського проводу Галичини та Буковини в революції 19181919 років. Україна модерна. Вип. 4-5. Львів, 2000. С. 187-245.

268. Панас Кость, о. Історія Української церкви. Львів, 1992. $160 \mathrm{c}$.

269. Пап С. Історія Закарпаття. Т. 1. Івано-Франківськ: Нова Зоря, 2001. $556 \mathrm{c.}$

270. Пап С. Історія Закарпаття. Т. 3. Івано-Франківськ: Нова Зоря, 2003. 644 c.

271. Папакін Г. Павло Скоропадський: патріот, державотворець, людина. Історико-архівні нариси. Київ, 2003. $282 \mathrm{c}$.

272. Паславський I. Берестейська Унія і українська християнська традиція. Львів: Місіонер, 1997. 63 с.

273. Паславський I. Іпатій Потій. До 450-річчя від дня народження. Ратуша. 1991. 28 вересня.

274. Патрило I. Джерела і бібліографія історії Української Церкви. В 3-х томах. Рим, 1975, 1988, 1992. Т. 1. 376 с.

275. Патер I. Г. Союз визволення України: проблема державності і соборності. Львів, 2000. 346 с.

276. Патер I. Перемишль і Перемищина під час російської окупації у березні-червні 1915 року (за матеріалами ЦДІА України у Львові). Перемишль $і$ Перемиська земля протягом віків. Перемишль; Львів, 1996. С. 159-169. 
277. Патрило I. Нарис історії Галицької провінції ЧСВВ. Записки ЧСВВ. Т. II, секц. 2. Рим, 1982. С. 43-130.

278. Пашук А. Українська церква і незалежність України. Львів: Видавничий центр ЛНУ, 2003. 363 с.

279. Пашук В. Товариство «Просвіта» у Львові. Львів. Історичні нариси. Львів: Інститут українознавства ім. І. Крип'якевича НАНУ, 1996. 276 с.

280. Пащенко В. Греко-католики в Україні: від 40-х років XX століття до наших днів. Полтава, 2002. 616 c.

281. Пащенко В. Православ'я в новітній історії України. Ч. 2. Полтава, $2001.736 \mathrm{c.}$

282. Пащенко В. Ярослав Галан. Міфи і факти біографії i творчості. Наукові записки Тернопільського державного педагогічного університету імені Володимира Гнатюка. Серія: Історія. Тернопіль, 2002. Вип. 2. С. 61-73.

283. Пекар Ат. Нариси історії Церкви Закарпаття: у 2 т. / Внутрішня історія. Рим; Львів: Місіонер, 1997. Т. 2. 1997. 492 с.

284. Пелехатий І. Я згину в тюрмі, а ви мусите жити... Нова зоря. 1997. 25 березня.

285. Перевезій В. Українська греко-католицька церква в політичній структурі східногалицького суспільства в 20-30-х рр. XX століття. Вісник Прикарпатського університету. Філософські і психологічні науки. 1999. № 1.

286. Перевезій $\quad$ В. Греко-католицька церква в умовах українсько-польської конфронтації 20-30-х рp. ХX ст. Автореферат дис. на здобуття наук. ступ. канд. іст. наук. Київ, 1998. $18 \mathrm{c}$.

287. Перемишль і Перемиська земля протягом віків. Вип. 3. Перемишль; Львів, 2003. 519 с.

288. Петлюра С. Статті. Київ, 1993. 340 с.

289. Петрів I. Митрополит Михайло Левицький - перший кардинал-українець. Берестейська Унія (1596-1996). Статті і матеріали. Львів: Логос, 1996. С. 185-192.

290. Пилипів I. Державотворча політика греко-католицької церкви у суспільно-політичному житті Західної України 20-30 років ХХ ст. Украӥнське державотворення: уроки, проблеми, перспективи. Ч. 1. Львів, 2001. С. 90-95. 
291. Пилипів I. Українська греко-католицька церква в період німецької окупації (1941-1944рр.). Галичина. Науковий $i$ культурно-просвітницький краєзнавчий часопис. 2002. № 8. C. $108-115$.

292. Полєк В. Духовна освіта на Прикарпатті. Нова зоря. 1991. Листопад. Ч. 33-34.

293. Полєк В. Священик-меценат. Нова зоря. 1991. Ч. 25-26.

294. Полонська-Василенко Н. Історія України. Т. 1. Київ: Либідь, 1992. 588 с.

295. Полонська-Василенко Н. Історія України. Т. 2. Київ: Либідь, 1992. 608 с.

296. Понятишин П. 3 моїх споминів. Митрополит Андрей Шептицький в Америці. Україниі у Вільному світі. Ювілейна книга Украӥнського Народного Союзу, 1894-1954. Джерсі Сіті; Нью-Джерсі, 1955. С. 19-36.

297. Понятишин П. Митрополит Андрей Шептицький в Америці. Слуга Божий Митрополит Андрей Шептицький в Америиі. Філадельфія, 1997. С. 110-123.

298. Поспеловский Д. Православная церковь в истории Руси, России и СССР: учеб. пособ. М.: Библейско-богословский институт Св. Апостола Андрея, 1996. 408 с.

299. Потічний П. УПА та німецька адміністрація. Зустрічі. 1991. № 2. С. 137-142.

300. Правда про унію. Док. і мат. Вид. друге, доп. Львів, 1968. $422 \mathrm{c}$.

301.Проповідь митр. Шептицького. Церква і церковна єдність. Документи і матеріали. Т. 1. Львів: Свічадо, 1995. C. 132-133.

302. Пушкаш П. Кир Теодор Ромжа. Життя і смерть єпископа. Львів, 2001. 244 с.

303. Расевич B. Митрополит Андрей (Шептицький) i проблема національно-політичної консолідації українців (19001918 роки). Ковчег. С. 212-223.

304. Расевич В. Українська національно-демократична партія (1899-1918 рр.). Автореф. дис. на здобуття наук. ступ. канд. іст. наук. Львів, 1996. 21 с.

305. Реєнт О. Українсько-польські відносини в XIX - на початку XX ст. Історіографічні дослідження в Украӥні / Голова 
редкол. В. Смолій; відп. ред. Ю. Пінчук. Вип. 13. У 2-х ч.; Україна - Польща: історія і сучасність. Збірник наук, праць і спогадів пам'яті П.М. Калиниченка (1923-1983). Ч. 1. Київ, 2003. C. 90-97.

306. Реєнт О. П., Лисенко О. П. Українська національна ідея і християнство. Київ: Богданна, 1997. 128 с.

307. Релігія в житті українського народу: зб. матеріалів. Мюнхен; Рим; Париж, 1966. 222 с.

308. Ржезац Т., Цуркан В. Розшукуються... Київ: Політвидав, 1989. 234 c.

309. Рибачук М. Ф., Уткін O.I., Кирюшко М. I. Національне відродження і релігія. Київ: Асоціація «Україно», 1995. 208 с.

310. «Русалка Дністрова»: Документи і матеріали / Упор. Ф. І. Стеблій та ін. Київ: Наукова думка, 1989. 542 с.

311. «Русская православная церковь стала на правильный путь». Докладные записки председателя Совета по делам Русской православной церкви при СНК СССР Г. Г. Карпова И. В. Сталину 1943-1946 гг. Исторический Архив. 1994. Т. 3. C. $139-148$.

312. Савчук Б. Просвітницька та соціально-економічна діяльність українських громадських товариств у Галичині (остання третина XIX - кінець 30-х pp. XX ст.). ІваноФранківськ, 1999. 134 с.

313. Савчук Б. Корчма: алкогольна політика і рух тверезості в Західній Україні у XIX - 30-х роках XX ст. Івано-Франківськ, 2001. 245 с.

314. Сагайдак М., Бубній П. Зарваниця у духовному i художньому слові, спогадах і переказах. Тернопіль, 1993. 111 с.

315. Сапеляк А. Київська Церква на слов'янському Сході: Канонічно-екуменічний аспект / Наукові редактори Ю. Сливка, О. Аркуша. Буенос-Айрес; Львів: Місіонер, 1999. 232 с.

316. Сапеляк А. Українська Церква на Другому Ватиканському соборі. Львів: Стрім, 1995. 214 с.

317. Спільне Пастирське послання митр. Андрея Шептицького та ін. єпископів до народу з приводу вбивства ц.-к. Намісника А. Потоцького 3 долученою інструкцією до духовенства. Митрополит Андрей Шептицьький: Життя $i$ 
Діяльність. Документи $i$ матеріали 1899-1944. Церква $i$ суспільне питання. Т. ІІ. Кн. 1. Львів: Місіонер, 1998. С. 424-425.

318. Сергійчук В. Греко-католицька церква в 1944-1991 pp. Украӥнський історичний журнал. 1996. № 4. С. 101-112.

319. Сергійчук В. Нескорена церква: Подвижництво грекокатоликів України в боротьбі за віру і державу. Київ: Дніпро, $2001.496 \mathrm{c}$.

320. Сердюк Н.С. Репресії радянських органів державної безпеки щодо Української греко-католицької церкви в 19441949 рр.: автореф. дис. на здобуття наук. ступеня канд. іст. наук: спец. 07.00 .01 «Історія України». К., 2006. 20 с.

321. Симоненко П. Комуністи про церкву та іiі роль у житті сучасної України. Голос України. 1999. 26 травня.

322. Сімкайло М., о. Берестейський собор і його значення. Берестейська Унія (1596-1996). Статті і матеріали. Львів: Логос, 1990. C. $75-78$.

323. Скочиляс I. Дослідження візитаційної документації Львівської єпархії у Галичині в другій половині XIX - першій половині ХХ століття. Ковчег. Ч. 3. Львів, 2001. С. 470-489.

324. Сліпий Йосиф, митрополит. Історія Вселенської церкви на Україні. Т. IV. Ч. 2. Рим, 1994. 99 с.

325. Слово Святішого Отця Івана Павла II до України. Львів, 2001. C. 86-92.

326. Слуга Божий Митрополит Андрей Шептицький. Календар 2004 р. / Упор. О. Гайова, відп. ред. о. Т. Янків. Львів, 2004. $26 \mathrm{c}$.

327. Соколовський О. Слуга Божий Єпископ Кир Іван Лятишевський: хронологія останніх років земних скитань. Нова зоря. 1993. Вересень. Ч. 33-34.

328. Соціологічні дослідження 2001 року релігійності, конфесійної належності, довіри Богу, Церкві та духовенству. Релігійна панорама. 2002. № 3. С. 41-51

329. Стеблецький С. Переслідування Української i Білоруської католицької церкви російськими царями. Мюнхен: Українське католицьке видавництво, 1954. 104 с.

330. Стеблій Ф. Духовний П'ємонт українців. Львівщина. Історико-культурні та краєзнавчі нариси. Львів: Центр Європи, 1998. C. 205-222. 
331. Стемпень С. Організація та територіальна структура Перемиської греко-католицької єпархії за владицтва єпископа Йосафата (Коциловського) ЧСВВ (1917-1946). Перемииль $i$ Перемиська земля протягом віків / За ред. С. Заброварного; упор. С. Заброварний, М. Литвин, Ф. Стеблій. Перемишль; Львів, 2003. C. $195-233$.

332. Стемпень С. Між окциденталізацією та візинтинізацією: проблема обрядової ідентичності Греко-католицької церкви в Речі Посполитій міжвоєнного періоду. Ковчег. Львів, 2003. Ч. 4. C. 86-100.

333. Стемпень С. Поляки і українці в II Речі Посполитій і спроба діалогу. Украйна-Польщза: історична спадщина і суспільна свідомість. Київ: Либідь, 1993. С. 211-222.

334. Степовик Д. Множинність і єдність церкви. Київська Старовина. 1993. № 5. С. 2-12.

335. Стоколос Н. Українська церква у контексті конфесійних трансформацій на Правобережній Україні під владою Російської імперії. Український історичний журнал. 2002. № 4. С. 94-109.

336. Стоколос Н.Г. Конфесійно-етнічні трансформації в Україні (XIX - перша половина XX ст.). Автореферат дис. на здобуття наук. ступ. доктора іст. наук. Київ, 2003. 49 с.

337. Столокос Н. Після Ужгородської унії. Етноконфесійні трансформації та адаптація греко-католиків Закарпаття. Людина $i$ cвim. 2001. № 5. С. 2-7.

338. Стоколос Н. Проблема етнічної i конфесійної ідентифікації лемків. Етнос $i$ релігія: теорія $i$ контекст сьогодення. Збірник наукових праць. Київ, 1998. С. 18-19.

339. Стоцький Я. Українська Греко-Католицька Церква i релігійне становище Тернопільщини (1946-1989). Тернопіль, 2003. $432 \mathrm{c}$.

340. Стоцький Я. Монастир Отців Василіян Чесного Хреста Господнього в Бучачі 1712-1996. Львів, 1997. 216 с

341. Стоцький Я. Історичні аспекти відновлення, реорганізації та структурування православних і католицьких церков в Україні у 1988-1999 роках. Київська Церква. Київ; Львів, 1999. № 2-3. C. 44-57.

342. Ступарик Б. Шкільництво Галичини (1772-1939). ІваноФранківськ: Акорд, 1994. 143 с. 
343. Ступарик Б., Моцюк В. Ідея національної школи та національного виховання в педагогічній думці Галичини (1772-1939). Коломия: Вік, 1995. 173 с.

344. Судоплатов П. Разведка и Кремль. Москва, 1996. 512 с.

345. Сурмач О. Греко-Католицька Богословська Академія в роки німецької окупації (1941-1944). Наукові зошити історичного факультету Львівського держсавного університету. Львів, 1999. Вип. 2. С. 185-187.

346. Сурмач О. Внутрішньодержавне життя УГКЦ в роки німецької окупації (1941-1944). Питання історї України. Чернігів, 2000. Т. 4. С. 175-179.

347. Сурмач О. Державно-церковні відносини на західноукраїнських землях (1939-1941). 1939 рік в історичній долі Украӥни і українців. Львів, 2001. С. 168-175.

348. Сурмач О. Польсько-український конфлікт і УГКЦ в часи німецької окупації. Українське релігіознавство. Київ, 2000. № 15. C. 59-67.

349. Сурмач О. Екуменічна діяльність УГКЦ в роки німецької окупації Галичини (1941-1943 рр.). Київська Церква. 2000. № 4. C. 72-78.

350. Сурмач О. Соціальна опіка УГКЦ в роки німецької окупації. Історія релігій в Україні. Львів, 1999. Кн. 2. С. 161-163.

351. Сурмач О., Малик Я. Преса про діяльність Української греко-католицької церкви в період німецької окупації (19411944 рр.). Украӥнська періодика: історія і сучасність. Львів, 1999. С. $169-179$.

352. Сухий О. Від русофільства до москвофільства. Російський чинник у громадській думці та суспільнополітичному житті галицьких українців у XIX столітті. Львів: Львів. нац. ун-т ім. І. Франка, 2003. 498 с.

353. Тиміш Л. I. Церковно-історичні дослідження у міжвоєнний період. Історія релігій в Украӥні. Праці Х Міжнар. наук. конф. (Львів, 16-19 травня 2000 р.). Львів, 2000. Кн. 1. C. $375-378$.

354. Тиміш Л. І. Наукові семінари Миколи Чубатого в Грекокатолицькій Богословській академії (до питання про розвиток церковно-історичних досліджень у міжвоєнному Львові. Вісник Київського університету. Історія. Київ, 2001. Вип. 58. С. 66-70. 
355. Тиміш Л. І. Археографічна діяльність наукових осередків міжвоєнного Львова (до проблем формування архівноджерельної бази дослідження історії української Церкви). Дрогобиџький краєзнавчий збірник. Вип. V. Дрогобич, 2001. C. 222-235.

356. Тиміш Л. І. Дослідження проблем 3 історії української Церкви вченими Ставропігійського інституту (міжвоєнний період). Історія релігій в Украӥні. Праці ХІІІІЇ міжн. наук. конф. (Львів, 20-22 травня 2003 р.). Кн. 1. Львів, 2003. С. 574-578.

357. Товариство «Просвіта» у Львові. Статути / Упор. В. Пашук. Львів, 1999. 272 с.

358. Товариство «Рідна школа»: історія і сучасність. Науковий альманах. Ч. 1. Львів, 2001. С. 168-169.

359. Тожецький Р. Митрополит Андрей Шептицький. Ковчег. Ч. 1. Львів, 1993. С. 101-112.

360. Трофим'як Б. Фізичне виховання і спортивний рух у Західній Україні (з поч. 30-х рр. XIX ст. до 1939 р.).Київ, 1997. 419 c.

361. Турій О. Греко-католицька церква та українська національна ідентичність у Галичині. Ковчег. Ч. 4. Львів, 2003. C. 67-85.

362. Турій О. «Попи і хлопи»: Соціальна «доктрина» грекокатолицького духовенства і національно-політична мобілізація українського селянства Галичини в середині XIX століття. Ковчег. Ч. З. Львів, 2001. С. 296-321.

363. Турій О. Соціальний статус і матеріальне становище греко-католицького духовенства Галичини в середині XIX ст. Ковчег. Ч. 2. Львів, 2000. С. 115-148.

364. Турій О. Конфесійно-обрядовий чинник у національній ідентифікації українців Галичини в середині XIX століття. Записки НТШ. Т. ССХХХІІІ. Львів: НТШ, 1997. С. 67-99.

365. Українське державотворення. Акт 30 червня 1941. Збірник документів і матеріалів. Львів; Київ: Літературна агенція «Піраміда», 2001. 605 с.

366. Ульяновський В. Церква в Українській державі 19171920 рр. (доба Української Центральної Ради). Київ: Либідь, 1997. $198 \mathrm{c}$. 
367. Уткін О. Львівський церковний собор 1946 р. в контексті тогочасних політичних реалій. Украӥнський історичний журнал. 1998. № 5. С. 99-110.

368. УХО та їі завдання. Намі вicmi. 1925. Ч. 1. С. 5-6.

369. Федорів Ю., о. Історія Церкви в Україні. Люблін, 1991. $364 \mathrm{c}$.

370. Федорів Юрій, о. Історія церкви в Україні. Торонто, 1967. $362 \mathrm{c}$.

371. Федунків Зеновій-Роман. Греко-католицьке духовенство в просвітніх змаганнях галицьких українців. Нова зоря. 1993. Грудень. Ч. 40.

372. Федунків 3.-Р. Протиалкогольне товариство «Відродження». Нова зоря. 1993. Жовтень. Ч. 37.

373. Филипович Л. Митрополит Андрей (Шептицький) і Іларіон (Огієнко): проблема національної церкви. Церква і соиіальні проблеми. Енцикліка «Сотий рік». Львів, 1993. C. 188-195.

374. Франко I. Панщина та іiі скасування 1848 р. в Галичині. Франко І. Зібрання творів. Т. 47. Київ: Наукова думка, 1986. C. 7-122.

375. Франко I. Твори в 50 томах. Т. 45. Філософські праці. Київ: Наукова думка, 1986. 574 с.

376. Футулуйчук В. Служба преподобництва УГА. Украӥнські варіанти. 1999. № 1-2. С. 70-73.

377. Химка I.-П. Греко-католицька церква в Галичині в 1772-1918 роках. Третій міжнародний конгрес україністів. Історія. Ч. І. Харків, 1996.С. 212-217.

378. Химка I.-П. Греко-католицька церква i національне відродження в Галичині 1772-1918. Ковчег. Львів, 1993. Ч. 3. С. $74-80$.

379. Хома І. Апостольський престіл і Україна 1919-1922. Рим, 1987. $134 \mathrm{c}$.

380. Хомин П. Митрополит Андрей Шептицький як Апостольський Візитатор для українців у Полудневій Америці. Богословія. Львів, 1926. № 1. С. 207-210.

381. Цвенгрош $\quad$ Г. Національно-державницькі погляди митрополита Андрія Шептицького й польсько-українська війна 1918-1919 рр. Україна-Польщяа: Історична спадщинна й суспільна 
свідомість. Матеріали конференції. Київ: Либідь, 1993. C. 172-183.

382. Цегельський Л. Від легенд до правди. Спомини про події в Україні, зв'язані з першим листопада 1918 р. Львів: Свічадо, 2003. $336 \mathrm{c}$.

383. Цегельський Л. Митрополит Андрей Шептицький. Короткий життєпис і огляд його церковно-народної діяльности. Філадельфія: Америка, 1937. 62 с.

384. Цегельський Л. Митрополит Андрій Шептицький: Короткий життєпис і огляд його церковно-народної діяльності. Львів: Місіонер, 1995. 80 с.

385. Цьольнер Е. Історія Австрії. Львів: Літопис, 2001. 712 с.

386. Чепіль М. Християнська педагогіка Юліана Дзеровича. Християнські ичінності: історія і погляду третє тисячоліття. 3б. наук. записок Національного університету «Острозька академія». T. VI. Острог, 2002. С. 439-446.

387. Чернега М. Життя і терпіння Спископа Величківського. Нова зоря. 1997. 27 травня.

388. Чорновол I. Українська фракція Галицького крайового сейму 1861-1901. Львів: Інститут українознавства ім. І. Крип’якевича НАН України, 2002. 288 с.

389. Чубатий М. Історія Християнства на Руси-Україні. В 2-х т. Рим; Нью-Йорк: Укр. Католицький ун-т ім. Св. Климента папи, 1965-1976. Т. 1.816 с. Т. 2. 264 с.

390. Шаблій О. Володимир Кубійович: Енциклопедія життя i творення. Париж; Львів, 1996. 704 с.

391. Шах С. Вступне слово. Лебедович I. Полеві духовники Украӥнської Галицької Армї. Вінніпег, 1963. С. 11-21.

392. Шашкевичіана. Збірник наукових праць. Вип. 1-2 / Інститут українознавства ім. І. Крип'якевича НАН України; Інститут-Заповідник Маркіяна Шашкевича у Вінніпезі; Шашкевичівська комісія у Львові; ред. кол.: Я. Ісаєвич та ін. Львів; Броди; Вінніпег: Просвіта, 1996. 468 с.

393. Швагуляк М. «Пацифікація». Польська репресивна акція у Галичині 1930 р. і українське суспільство. Львів, 1993. 51 с.

394. Швагуляк М. Українська католицька народна партія. Довідник з історії України. Київ, 2002. С. 921. 
395. Швагуляк M. Християнський католицький союз. Довідник з історії України. Київ, 2002. С. 964-965.

396. Швець I. Збірник. Статті, доповіді, промови. Сідней, $1996.250 \mathrm{c}$.

397. Шевців I., о. Збірник. Статті, доповіді, промови. Львів: «Свічадо», 1996. 250 с.

398. Шептицький А. Пастирське послання. Церква і суспільне питання. Т. 2. Кн. 1. Львів: Місіонер, 1998. С. 212-215.

399. Шептицький Андрей, митрополит. До духовенства. Львівські єпархіальні відомості. 1939. № 9-10. С. 205.

400. Шептицький Андрей, митрополит. О Квестії Соціяльній. Церква і суспільне питання. Кн. І. С. 142-179.

401. Шептицький Андрей, митрополит. Як будувати рідну хату? Митрополит Андрей Шептицький. Матеріали та документи (1865-1944). 2-ге видання / За редакцією Заборовського Я.Ю. Львів; Івано-Франківськ: Олір, 1995. C. $70-104$.

402. Шкраб'юк П. Виноградник Господній; Історія життя о. дра Йосифа Кладочного. Львів : Місіонер, 1995. 280 с.

403. Шкраб'юк П. Крехів: Дороги земні та небесні. Львів: Місіонер, 2002. 413 с.

404. Шуба О. Релігія в етнонаціональному розвитку України. Київ: Криниця, 1999. 323 с.

405. Янів В. Нариси до історії української етнопсихології. Мюнхен: В-во УВУ, 1993. 217 с.

406. Яновський М. Правда про Гошівський монастир. Нова зоря. 1994. Січень. Ч. 2.

407. Якимович Б. Збройні Сили України. Нарис історії. Львів: Інститут українознавства НАНУ, 1996. 360 с.

408. Яремич Г. Дорога до храму: Ансамбль Жовківської Василіанської церкви, монастиря, друкарні. Львів: Місіонер, 2000. $32 \mathrm{c}$.

409. Ясіновський Ю. Дяко-учительський інститут у Перемишлі. Перемишль і Перемиська земля протягом віків / За ред. С. Заброварного; упор. С. Заброварний, М. Литвин, Ф. Стеблій. Перемишль; Львів, 2003. С. 249-259.

410. Drozd R. Polityka władz wobec ludności ukraińskiej w Polsce w latach 1944-1989. Warszawa, 2001 S. 30-307. 
411. Gudziak B., Hurkina S., Turij O. Hierarchia i duchowieństwo ukraińskiego kościola grecko-katolickiego wpodziemiu. Polska Ukraina. 1000 lat sąsiedztwa. T. 4. Przemyśl, 1998. S. 312-318.

412. Himka J.-P. Priests and Peasants: The Greek Catholic Pastor and the Ukrainian National Movement in Austria, 1867-1900. Canadian Slavonic Papers. 1979. N 21 (1). P. 1-14.

413. Himka J.-P. The Greek Catholic Church and Nation-Building in Galicia, 1772-1918. Harvard Ukrainian Studies. 1984. N 8 (3-4). P. 426-452.

414. Himka J.-P. Galician Villagers and the Ukrainian National Movement in the Nineteenth Century. Houdmills, 1988. 360 p.

415. Himka J.-P. Religion and Nationality in Western Ukraine: The Greek Catholic Church and the Ruthenian National Movement in Galicia, 1867-1900. Montreal-Kingston (Ontario), 1999. 236 p.

416. Jurkiewicz Jarosław. Watykan a Polska w okresie miedzywojennym 1918-1939. Warszawa, 1958. 313 s.

417. Krasowski Krzysztof. Episkopat Katolicki w II Rzeczypospolitej. Warszawa; Poznań. 288 s.

418. Łubieński Henryk. Kościół Grecko-Katolicki w województwach południowo-wschodnich. Warszawa, 1935. $213 \mathrm{~s}$.

419. Polska - Ukraina. 1000 lat sąsiedztwa. T. 2: Studia z dziejow chrześciaństwa na pograniczu kultumym i etnicznym / Pod red. S. Stępnia. Przemyśl, 1994. 430 s.

420. Polska - Ukraina. 1000 lat sąsiedztwa. T. 3: Studia z dziejow chrześciaństwa na pograniczu kultumym i etnicznym / Pod red. S. Stępnia. Przemyśl, 1996. 336 s.

421. Polska-Ukraina. 1000 lat sąsiedztwa. T. 5: Miejsce i rola Kościoła Greckokatolickiego w Kościełe powszechnym. Przemysl, 2000. $568 \mathrm{~s}$.

422. Popiński K., Kokurin A. Drogi śmierci. Ewakuacja więzień sowieckieh z kresów Wschodnich II Rzeczy pospolitej w czerwcu i lipcu 1941. Warszawa, 1995.S. 7-74, 98-104.

423. Rublowa N. Świadectwo wiary... Polska-Ukraina. 1000 lat sąsiedztwa. T. 5. Przemysl, 2000. S. 123-127.

424. Prus Edward. Władyka świętojurski. Warszawa, 1985. $286 \mathrm{~s}$.

425. Rzemieniuk F. Unici Polscy. 1596-1946. Siedlce, 1998. $286 \mathrm{~s}$. 
426. Sliwa W. Kościół grecko-katolicki w Polsce w latach 19181939. Kościót w II Rzeczypospolitej / Red. Z. Zilinski, S. Wilka. Lublin, 1981. S. 149-164.

427. Soczyński Roman. 400-lecie Unii Breskiej. 1596-1996. Warszawa, 1996. $232 \mathrm{~s}$.

428. Torzecki R. Metropolita Andrej Szeptycki. Znak. 1988. N 9. S. 55-63.

429. Ukraińcy w najnowszych dziejach Polski(1918-1989). T. 1 / Pod red. R. Drozda. Slupsk; Warszawa, 2000. S. 159-184.

430. Umińskij Józef. Historiografm Kościelna (stan badań i wazniejsze postulaty). Kwartalnik historyczny. Lwów, 1937. R. LI. S. 329-332. 
Publishing house "Liha-Pres"

9 Kastelivka str., Lviv, 79012, Ukraine 44 Lubicka str., Toruń, 87-100, Poland

Printed by the publishing house "Liha-Pres"

Passed for printing: July 10, 2020.

A run of 150 copies. 